

\section{DISCLAIMER}

Portions of this document may be illegible in electronic image products. Images are produced from the best available original document. 
SEP 281994

\section{Sotation 21}

To: (Receiving Organization)

Waste Tank Safety Program

5. Proj./Prog./Oept./0iv.:

Flammable Gas Tank Safety

8. Originator Remarks:

This document examines the hazards associated with flammable gas DSTs. The likelihood of a gas burn is considered and the consequences of a postulated plume burn is calculated including radiation doses.

11. Receiver Renarks:
3. From: (Originating Organization)

TWRS Safety Analysis and Engineering

6. Cog. Engr.:

G. L. Fox

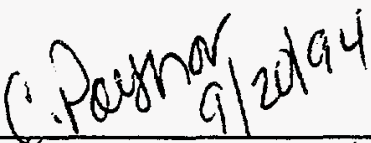

Page 1 of 1

1. EDT $1 5 6 7 \longdiv { 7 9 }$

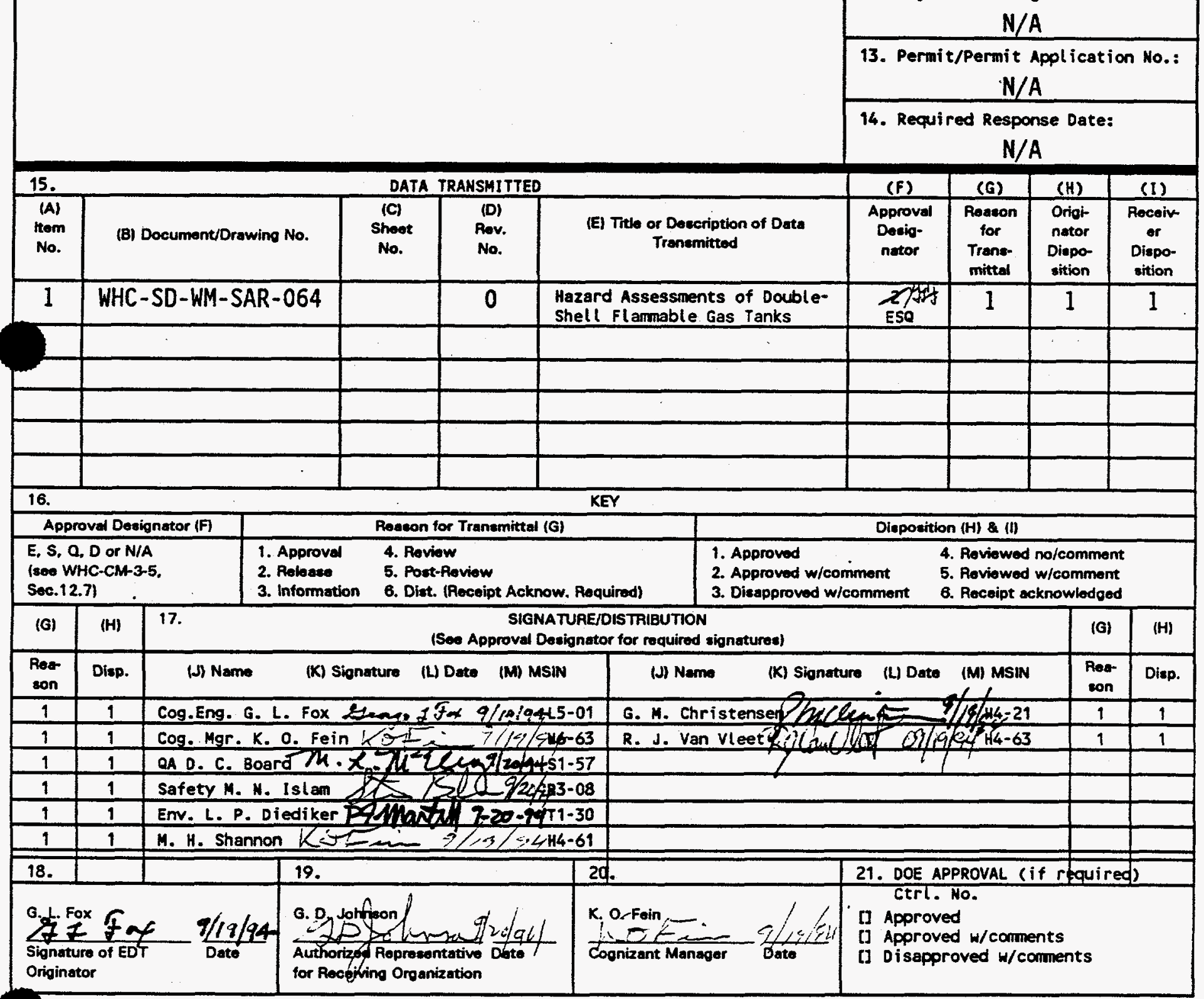




\section{RELEASE AUTHORIZATION}

Document Number: WHC-SD-WM-SAR-064, Revision 0

$\begin{array}{ll}\text { Document Title: } & \text { Hazard Assessments of Double-She11 Flammable Gas } \\ \text { Tanks }\end{array}$

Release Date: $\quad$ September 28, 1994

This document was reviewed following the procedures described in WHC-CM-3-4 and is:

APPROVED FOR PUBLIC RELEASE

WHC Information Release Administration Specialist:

$\frac{\text { MN. Bosten }}{\text { M. N. Boston }} \frac{9 / 28 / 94}{\text { (Date) }}$




\section{SUPPORTING DOCUMENT}

\begin{tabular}{|c|c|c|}
\hline $\begin{array}{l}\text { 2. Title } \\
\text { Hazard Assessments of Double-Shell Flammable Gas } \\
\text { Tanks }\end{array}$ & $\begin{array}{l}\text { 3. Number } \\
\text { WHC-SD-WM-SAR-064 }\end{array}$ & $\begin{array}{c}\text { 4. Rev No. } \\
0\end{array}$ \\
\hline $\begin{array}{l}\text { 5. Key words } \\
\text { Hydrogen tank safety, crust burn, waste tank } \\
\text { safety analysis, defense waste storage, waste } \\
\text { management }\end{array}$ & $\begin{array}{l}\text { 6. Author } \\
\text { Name: G. L. Fox, } \\
\text { Organization/Charge Code }\end{array}$ & $3 E$ \\
\hline
\end{tabular}

\section{Abstract}

This document examines the flamable gas hazards associated with double-shell tanks.

The likel ihood of a gas burn is considered and the consequences of a postulated gas plume tank dome space is shown to be extremely important and gas which migrates to the top of the tank is below flammable concentrations before exiting. None of the parameteric cases considered resulted in a propagating reaction in the floating waste crust, even if the crust was considered dry.

8. PURPoot AuO USE OE DOCUMEH - Thio document was prepared for dse 2. Wuthin the U.S Department of Energy and its contyctors. It is to be used any to perform, direct, or integrate work under b.s. Department of Energh contracts. This abcument is not apgeored for pabl ic setease ynil revioned.

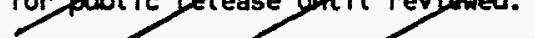

PATEM STATyo - This document topy, since it is transmited in advance of patent Ctearance Is made available in confidence solely for use in performane of work undar contraets with the עrs. Depactient of Entrgy. Ins documen is not 00 be published nor its contents otberwise disseminated or used for purposes other than specified above before patent approval for such petease or use has been secured, upor request from the Datent Counsel, 40. Department of Energy $F$ istd office, Richlang WA.

OISCLAIMER - This report was prepared as an account of work sponsored by an agency of the United States Goverment. Neither the United States Government nor any agency thereof; nor any of their employees, nor any of their contractors, subcontractors or their employees, makes any warranty, express or implied, or assumes any legal liability or responsibility for the accuracy, completeness, or any third party's use or the results of such use of any information, apparatus, product, or process disclosed, or represents that its use would not infringe privately owned rights. Reference herein to any specific commercial product, process, or service by trade name, trademark, manufacturer, or otherwise, does not necessarily constitute or imply its endorsenent, recommendation, or favoring by the United States Goverment or any agency thereof or its contractors or subcontractors. The views and opinions of authors expressed herein do not necessarily state or reflect those of the United States Government or any agency thereof.

9. Impact Level $2 \mathrm{ESQ}$ DB
10.

RELEASE STAMP

101-AW, 103-AN, 104-AN, 105-AN, and 103-SY.

OFFICIAL RELEASE BYWHC DATE SEP 281994

35 Station 21 


$$
\text { WHC-SD-WM-SAR-064, Rev. } 0
$$

\title{
HAZARD ASSESSMENTS OF DOUBLE-SHELL FLAMMABLE GAS TANKS
}

\author{
by \\ - G. L. Fox \\ D. D. Stepnewski
}

September 1994 
WHC-SD-WM-SAR-064, Rev. 0

This page intentionally left blank. 
WHC-SD-WM-SAR-064, Rev. 0

\section{ACKNOWLEDGEMENT}

The consultation support of D. E. Simpson, Westinghouse Hanford Company, on technical issues and L. Jensen, Westinghouse Hanford Company, and P. D. Whitney, Pacific Northwest Laboratory, on statistical data treatment are acknowledged with appreciation by the authors. The authors would also like to acknowledge the contributions of $L$. A. Tusler, Westinghouse Hanford Company, who provided information and plots of various tank measurements, and C. J. Moore and M. P. Weis, Westinghouse Hanford Company, who performed extensive overchecks and provided insights which improved the plume burn modeling. 
WHC-SD-WM-SAR-064, Rev. 0

This page intentionally left blank. 


\section{CONTENTS}

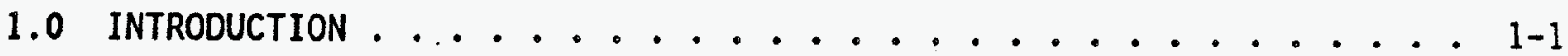

2.0 SUMMARY AND CONCLUSIONS .................... 2-1

3.0 WASTE CHARACTERIZATION ..................... 3-1

3.1 CHEMICAL PROPERTIES . . . . . . . . . .

3.2 THERMAL PROPERTIES $\ldots \ldots \ldots$

3.3 RADIONUCLIDE CHARACTERIZATION $\ldots \ldots \ldots$

3.3.1 Radionucl ide Inventories .......... 3-6

3.3.2 Inventory for Radiological Dose Consequences

Evaluation ................. 3-8

4.0 GAS CHARACTERIZATION .................. 4-1

4.1 GAS RELEASE QUANTITIES $\ldots \ldots \ldots \ldots . \ldots . \ldots . \ldots 4-2$

4.2 GAS COMPOSITION . . . . . . . . . . $4-6$

4.3 TOTAL GAS RELEASE QUANTITIES . . . . . . . . . . . 4-7

4.4 COMPLETE MIXING RESULTS . . . . . . . . . . . 4-8

5.0 GAS MIXING STUDIES . . . . . . . . . . . . 5-1

5.1 DEFINITION OF CONDITIONS $\ldots \ldots \ldots$

5.2 GOTHIC CODE MODEL . . . . . . . . . . . . 5-3

5.3 TIME AT RISK . . . . . . . . . 5-6

5.4 SUMMARY OF MIXING RESULTS ............ . . . . . .

5.5 CONCENTRATION DISTRIBUTION $\ldots \ldots$

5.6 FLAMMABILITY DATA . . . . . . . . . . . . . 5-21

6.0 PLUME BURN MODEL . . . . . . . . . . ..... 6-1

6.1 GAS MODEL . . . . . . . . . . . . . . 6-1

6.2 GAS ENERGY OF COMBUSTION . . . . . . . . . . $6-2$

6.3 RADIATION HEAT TRANSFER . . . . . . . . . . . 6-4

6.4 CONVECTIVE HEAT TRANSFER ............. $6-5$

7.0 CRUST REACTIONS .................. . . . . . .

7.1 CHEMICAL KINETICS ................... 7-1

7.1.1 Adiabatic Calorimetry Tests . . . . . . . 7-1

7.1.2 Measured Crust Reactivity for Tank 101-SY . . . . . 7-2

7.1.3 Basis for Extrapolation of Calorimetry....... . 7-4

7.2 RESULTS OF CALCULATIONS .............. . . 7-6

7.2.1 Best Estimate Cases . . . . . . . . . . . 7-7

7.2.2 Parametric Studies . . . . . . . . . . 7-9

7.2.3 Results of Conservative Calculations . . . . . 7-13

7.2.3.1 Tank 103-SY . . . . . . . . . 7-13

7.2.3.2 Conservative Maximum Burn Conditions . . . . 7-13

7.2.4 Evaluation of Margins ............ . . . . . . . .

8.0 CONSEQUENCES OF SLURRY GAS BURN EVENTS . . . . . . . . . . . 8-1

8.1 TANK STRUCTURAL REACTIONS ............... . 8-1

8.2 RADIOLOGICAL SOURCE TERMS ........... $8-4$

8.2.1 Thermal Release . . . . . . . . . . . . . 8-4

8.2.2 Mechanical Release . . . . . . . . . . . 8-6

8.2.3 Isotopic Releases from the Primary Exhaust System . . 8-8 
WHC-SD-WM-SAR-064, Rev. 0

CONTENTS (continued)

8.3 RADIOLOGICAL DOSE CONSEQUENCES . . . . . . . . 8-8

8.3.1 Results .................. 8-8

8.3.2 Compliance with Risk Acceptance Guidelines ..... 8-11

8.4 OPERATIONAL RISK ASSESSMENT ............. 8-11

8.4.1 In-Tank Ignition Sources ........... 8-11

8.4.2 Earthquakes as an Ignition Source ........ 8-12

8.4.3 Lightning as an Ignition Source ......... 8-14

8.4.4 Flammable Gas Burn Likelihood .......... 8-15

9.0 REFERENCES ........................... 9 . .

\section{APPENDICES}

A DERIVATION OF THE THERMODYNAMIC RELATIONS AND SOLUTION PROCEDURE . . A-i

B Am-241 INVENTORY IN TANK 104-AN ................ B-i

C CALCULATION OF THERMAL RELEASE COMPONENT OF RADIOLOGICAL

SOURCE TERM ..................... c

D PRESSURE CAPABILITY FOR DOUBLE-SHELL TANKS ......... D-i

E DYNAMIC LOAD FACTORS ................. E- . . .

F RADIOLOGICAL DOSE CALCULATIONS ................... F-i

G RELATIONSHIP OF THUNDERSTORMS TO GAS RELEASE EVENTS ........ G-i

H SUMMARY OF CONSERVATISMS .................... H-i 
WHC-SD-WM-SAR-064, Rev: 0

\section{LIST OF FIGURES}

1-1. Plume Gas Release with Combustion ............ 1-2

4-1. Gas Mixing Indications in Tank 101-SY .......... 4-3

4-2. Tank 241-SY-101 Surface Level ... . . . . . . . . . 4 4-5

4-3. Completely Mixed Slurry Gas Concentrations ............ 4-9

5-1A. GOTHIC Node Arrangement for Mixing Studies . . . . . . . . 5-4

5-1B. GOTHIC Node Arrangement for Mixing Studies . . . . . . . 5-5

5-2. Gas Concentration vs. Time - 5 Minute Gas Input Time . . . . . 5-7

5-3. Gas Concentration vs. Time - 5 Minute Input Time . . . . . . 5-7

5-4. Gas Concentration vs. Time - 10 Minute Gas Input Time . . . . 5-8

5-5. Gas Concentration vs. Time - 10 Minute Gas Input Time . . . . 5-8

5-6. Gas Concentration vs. Time - 50 Minute Gas Input Time . . . . 5-9

5-7. Gas Concentration vs. Time - 50 Minute Gas Input Time . . . . 5-9

5-8. Gas Concentration vs. Time - 100 Minute Gas Input Time . . . . 5-10

5-9. Gas Concentration vs. Time - 100 Minute Gas Input Time . . . . . 5-10

5-10. Gas Concentration vs. Time $-4,000 \mathrm{ft}^{3}$ slurry Gas Input, 50 Minute Input Time................ . 5-11

5-11. Gas Concentration vs. Time $-4,000 \mathrm{ft}^{3}$ Slurry Gas Input, 50 Minute Input Time............... . 5-11

5-12. Gas Concentration vs. Time $-47,700 \mathrm{ft}^{3}$ Tank Free Volume, 50 Minute Gas Input Time ........... 5-13

5-13. Gas Concentration vs. Time $-47,700 \mathrm{ft}^{3}$ Tank Free Volume, 50 Minute Gas Input Time ............ 5-13

5-14. Gas Concentration vs. Time $-83,100 \mathrm{ft}^{3}$ Tank Free Volume, 50 Minute Gas Input Time ............. 5-14

5-15. Gas Concentration vs. Time $-83,100 \mathrm{ft}^{3}$ Tank Free Volume, 50 Minute Gas Input Time ............. 5-14

5-16. Gas Concentration vs. Time $-100 \mathrm{ft}^{2}$ Gas Inlet Area, 50 Minute Gas Input Time . . . . . . . . . . . . 5-17 


\section{LIST OF FIGURES (continued)}

5-17. Gas Concentration vs. Time $-100 \mathrm{ft}^{2}$ Gas Inlet Area, 50 Minute Gas Input Time ............ . . 5-17

5-18. Gas Concentration vs. Time $-4,000 \mathrm{ft}^{2}$ Gas Inlet Area, 50 Minute Gas Input Time ............. . . 5-18

5-19. Gas Concentration vs. Time $-4,000 \mathrm{ft}^{2}$ Gas Inlet Area, 50 Minute Gas Input Time. ... . . . . . . . . 5-18

7-1. Tank 101-SY Calorimetry .............. 7-3

7-2. Temperature Histories for Tank 101-AW . . . . . . . 7-10

7-3. Crust Exothermic Reactions .............. 7-11

7-4. Thermal Radiation Coefficient (Tank 101-AW) . . . . . . . 7-12

7-5. Self-Extinguishing Limits (Dry Crust) ......... 7-15

8-1. STurry Gas Burn Pressures for Best Estimate Cases ... . . . 8-2

8-2. S7urry Gas Burn Pressures for Conservative Cases . . . . . . . 8-3

8-3. Dome Local Discontinuities Principal Strain vs. Static Pressure . 8-5

\section{LIST OF TABLES}

2-1. Comparisons of Flammable Gas Double-Shell Tanks with Tank 101-SY . 2-1

2-2. Slurry Gas Burn Pressures ............ 2- 24

2-3. Radiological Dose Consequences, EDE, rem ......... 2-4

2-4. Ignition Source Frequency ............ 2-5

3-1. Double-She11 Tank Waste Descriptions ............. 3-1

3-2. Waste Type and Volume by Tank ............ 3-2

3-3. Waste Characterization by Tank ............ 3-2

3-4. Estimated Chemical Waste Tank Inventory .......... 3-3

3-5. Weight Fractions of More Significant Species.......... 3-5

3-6. Crust Thermophysical Properties ........... 3-6 
WHC-SD-WM-SAR-064, Rev. 0

\section{LIST OF TABLES (continued)}

3-7. Radionuclide Concentrations in Double-She11 Waste Tanks $(\mu \mathrm{Ci} / \mathrm{L})$. 3-7

3-8. Crust Radionuclide Inventories $(\mu \mathrm{Ci} / \mathrm{g}) \ldots \ldots$ 3-9

3-9. Maximum Crust Radionuclide Concentration $(\mu \mathrm{Ci} / \mathrm{g} \ldots \ldots$. . . . 3-10

4-1. Dry Gas Release Quantities ........ . . . . . . . 4-4

4-2. Best Estimate and Conservative Estimate for Release Gas

Compositions ................... 4-6

4-3. Total Gas Release Quantities . . . . . . . . . . . 4-7

5-1. Tank Free Volume ............... 5-2

5-2. Maximum Gas Release ............... 5-2

5-3. Node Spacing for Levels in Figures 5-1A and 5-1B ....... 5-3

5-4. Time at Risk - Base Cases ... . . . . . . . . . 5-12

5-5. Time at Risk versus Free Volume ... . . . . . . . 5-15

5-6. Time at Risk versus Gas Inlet Area . . . . . . . . . . 5-15

5-7. Effect of Gas Input Rate on Concentration Distribution . . . . . 5-20

5-8. Effect of Free Volume on Concentration Distribution,

50 Minute Input Time.............. 5-20

5-9. Effect of Gas Input Area on Concentration Distribution . . . . . 5-21

5-10. Effect of Total Gas Input on Concentration Distribution . . . . 5-21

5-11. Burn Pressure Ratios: Experimental/Calculated . . . . . . . 5-22

6-1. Composition Fractions for Best Estimate Gas ... . . . . . 6-4

7-1. Kinetic Parameters for Tank 101-SY . . . . . . . . . 7-2

7-2. First order Kinetics .............. 7-6

7-3. Best Estimate Parameters . . . . . . . . . . 7-7

7-4. Peak Values for Plume Burning with Best Estimate Conditions . . 7-8

8-1. STurry Gas Burn Pressures . . . . . . . . . . . . . 8-1

8-2. Maximum Crust Temperatures . . . . . . . . . . 8-6 
WHC-SD-WM-SAR-064, Rev. 0

\section{LIST OF TABLES (continued)}

8-3. Mechanical Release Components ............. 8-7

8-4. Source Term - Best Estimate ... . . . . . . . 8-8

8-5. Source Term - Conservative .............. 8-9

8-6. Isotopic Releases from the Primary Exhaust System Inventory . . 8-9

8-7. Ventilation System Releases Dose Consequences . . . . . . 8-10

8-8. Best Estimate Flammable Gas Burn Radiological Dose Consequences . 8-10

8-9. Bounding Conservative Flammable Gas Burn Radiological

Dose Consequences .................. 8-10

8-10. Radiological Risk Acceptance Guideline . . . . . . . . . 8-11

8-11. Ignition Frequency .................. 8-15 
WHC-SD-WM-SAR-064, Rev. 0

\subsection{INTRODUCTION}

The double-shell tanks (DST) were constructed at the Hanford Site in the mid 1970's to early 1980's for the storage of radioactive waste from chemical processing of spent reactor fuel. Tank 101-SY has attracted the majority of attention since 1990, when it was recognized that the slurry gas components were flammable by themselves without requiring mixing with the oxygen in air. Early concerns centered around pockets of flammable gas which might get trapped and ignite under a floating crust. Subsequent investigations using observations obtained with a video camera and retrieved crust samples have shown that wet crust does not have sufficient strength to behave in this fashion. The sludge/gas material from the nonconvective region in the lower portion of the tank erupts through the floating crust and releases its slurry gas directly into the tank dome space. Figure 1-1 shows a diagram of a DST with a'released gas plume where burning is postulated. Tank hazard assessments are now directed toward the following primary safety issues:

- Does accumulation and release of flammable gases occur in sufficient quantities that the lower flammability limit (LFL) is exceeded in the tank dome space?

- If flammable gases were ignited and burned, would a selfpropagating secondary chemical reaction occur in the floating crust?

- Would dose consequences resulting from a flammable gas burn exceed site acceptance guidelines?

Tank 101-SY had the largest level fluctuations and episodically released the largest quantities of gas. The data gathering system has been markedly improved during the last several years with the addition of new thermocouple trees, gas monitors, and more frequent measurements of surface level. Waste samples have been obtained, most recently in 1992, which were used to rule out potential crust burn propagation from a gas burning event. Because the gas release quantities were so large, open tank work activities were restricted to a period following a gas release event when the likelihood of additional releases were small (work windows). During 1993, a mixing pump was installed so that gas accumulation and episodic gas releases no longer occur. The experience gained in analyzing gas release events (GRE) for tank 101-SY has direct application to other tanks.

This report is the fourth in a series of hazard assessments performed on the double-shell flammable gas watch list tanks. Previous reports dealt with tanks 101-SY (Fox et al. 1990, 1992) and 103-SY. (Fox et al. 1993). This report focuses on hazards associated with the remaining double-shell watch list tanks (101-AW, 103-AN, 104-AN, and 105-AN). While a similar assessment has already been performed for tank 103-SY, it is also included here to incorporate a more representative slurry gas mixture and provide a consistent basis for comparing results for all the flammable gas tanks. This report is intended to provide an in-depth assessment by considering the details of the 
GRE and slurry gas mixing as the gas is released from the waste. The consequences of postulated gas ignition are evaluated using a plume burn model and updated ignition frequency predictions. Tank pressurization which results from a gas burn, along with the structural response, is also considered. The report is intended to support the safety basis for work activities in flammable gas tanks (Van Vleet 1994) by showing margins to safety limits that are available in the design and procedures. This report is also intended to serve as a safety basis for closure of the Unreviewed Safety Question (USQ) on these tanks and to identify additional information required to close the safety issue.

Figure 1-1. Plume Gas Release with Combustion.

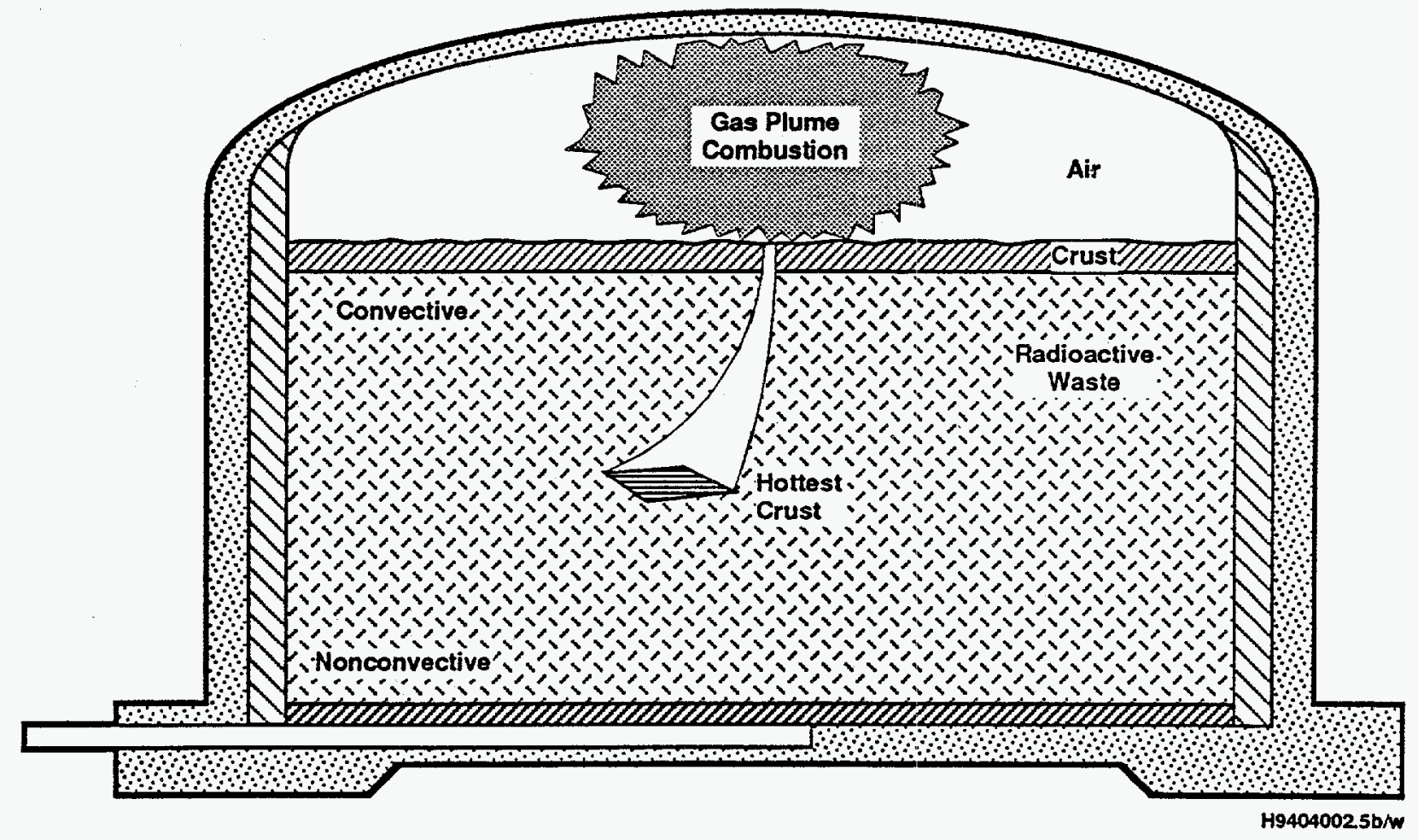




\subsection{SUMMARY AND CONCLUSIONS}

This document examines the hazards associated with slurry gas emissions from waste stored in the double-shell flammable gas watch 7 ist tanks except for tank 101-SY, which was addressed previously (Fox et a1. 1992). The likelihood of gas burns is examined and the consequences of postulated plume burns are evaluated. Slurry gas mixing with air in the tank dome space is rapid. All of the tanks are shown to have dome concentrations which are less than the LFL when the slurry gas at studied compositions becomes well mixed with air. In addition, the upper regions of the tanks remain below the LFL so gas ignition cannot occur from the top.

Unlike tank 101-SY, tanks 101-AW, 103-AN, 104-AN, 105-AN, and 103-SY have more sporadic gas releases which involve local waste regions and result in small GRE and crust drops. Waste in tank 101-SY, on the other hand, showed whole-tank roll-over events which resulted in large surface level drops and released large quantities of gas. Because of this, estimates of maximum gas release quantities do not use models developed from tank 101-sy but rely on using maximum crust drops to calculate the size of gas releases for the hazard assessment. Gas release timing and quantity inferred from crust drops are arbitrarily increased to provide conservative margins.

These tanks have many similarities with tank 101-SY but they appear to be less hazardous. Table 2-1 shows selected comparisons.

Table 2-1. Comparisons of Flammable Gas Double-Shell Tanks with Tank 101-SY.

\begin{tabular}{|c|c|c|c|c|c|c|}
\hline & $101-A W$ & $103-A N$ & 104-AN & 105-AN & 103-SY & $101-\mathrm{SY}$ \\
\hline Waste type & DSSF & DSS & DSSF & DSS & $\mathrm{CC}$ & $\mathrm{CC}$ \\
\hline Waste height & $\begin{array}{l}409 \mathrm{in} . \\
10.39 \mathrm{~m}\end{array}$ & $\begin{array}{l}346 \mathrm{in} . \\
8.79 \mathrm{~m}\end{array}$ & $\begin{array}{l}387 \mathrm{in} . \\
9.83 \mathrm{~m}\end{array}$ & $\begin{array}{l}411 \mathrm{in} . \\
10.44 \mathrm{~m}\end{array}$ & $\begin{array}{l}274 \mathrm{in} . \\
6.96 \mathrm{~m}\end{array}$ & $\begin{array}{l}408 \text { in. } \\
10.36 \mathrm{~m}\end{array}$ \\
\hline Dome airspece & $\begin{array}{l}37634 t^{3} \\
1065.7 \mathrm{~m}^{3}\end{array}$ & $\begin{array}{l}61100 \mathrm{ft}^{3} \\
1730.2 \mathrm{~m}^{3}\end{array}$ & $\begin{array}{l}46010 \mathrm{ft}^{3} \\
1302.9 \mathrm{~m}^{3}\end{array}$ & $\begin{array}{l}37360 \mathrm{tt}^{3} \\
1057.9 \mathrm{~m}^{3}\end{array}$ & $\begin{array}{l}87609 \mathrm{ft}^{3} \\
2480.8 \mathrm{~m}^{3}\end{array}$ & $\begin{array}{l}37540 \mathrm{ft}^{3} \\
1063.0 \mathrm{~m}^{3}\end{array}$ \\
\hline $\begin{array}{l}\text { Maximum } 24 \text { hr crust drop during } \\
\text { GRE }\end{array}$ & $\begin{array}{l}1.6 \mathrm{in} . \\
4.06 \mathrm{~cm}\end{array}$ & $\begin{array}{l}2.5 \mathrm{in} . \\
6.35 \mathrm{~cm}\end{array}$ & $\begin{array}{l}3.6 \mathrm{in} . \\
9.14 \mathrm{~cm}\end{array}$ & $\begin{array}{l}2.3 \mathrm{in} . \\
5.84 \mathrm{~cm}\end{array}$ & $\begin{array}{l}1.7 \mathrm{in} . \\
4.32 \mathrm{~cm}\end{array}$ & $\begin{array}{l}10 \mathrm{in.} \\
25.4 \mathrm{~cm}\end{array}$ \\
\hline Averaged waste temp degree & $\begin{array}{l}99^{\circ} \mathrm{F} \\
37.2^{\circ} \mathrm{C}\end{array}$ & $\begin{array}{l}109^{\circ} \mathrm{F} \\
42.8^{\circ} \mathrm{C}\end{array}$ & $\begin{array}{l}110^{\circ} \mathrm{F} \\
43.3^{\circ} \mathrm{C}\end{array}$ & $\begin{array}{l}102^{\circ} \mathrm{F} \\
38.9^{\circ} \mathrm{F}\end{array}$ & $\begin{array}{l}100^{\circ} \mathrm{F} \\
37.8^{\circ} \mathrm{C}\end{array}$ & $\begin{array}{l}115^{\circ} \mathrm{F} \\
48.1^{\circ} \mathrm{C}\end{array}$ \\
\hline Tank heat generation & $\begin{array}{l}34400 \mathrm{Btu} / \mathrm{hr} \\
10.08 \mathrm{~kW}\end{array}$ & $\begin{array}{l}36660 \mathrm{Btw} / \mathrm{hr} \\
10.74 \mathrm{~kW}\end{array}$ & $\begin{array}{l}44940 \mathrm{Btw} / \mathrm{hr} \\
13.17 \mathrm{~kW}\end{array}$ & $\begin{array}{l}35090 \mathrm{Btu} / \mathrm{hr} \\
10.28 \mathrm{~kW}\end{array}$ & $\begin{array}{l}23500 \mathrm{Btu} / \mathrm{hr} \\
6.89 \mathrm{~kW}\end{array}$ & $\begin{array}{l}40000 \mathrm{Btu} / \mathrm{hr} \\
11.72 \mathrm{~kW}\end{array}$ \\
\hline Surface rise rate & $\begin{array}{l}0.01 \mathrm{in} / \mathrm{day} \\
0.0254 \mathrm{~cm} / \mathrm{day}\end{array}$ & $\begin{array}{l}0.006 \mathrm{in} / \mathrm{day} \\
0.0152 \mathrm{~cm} / \mathrm{day}\end{array}$ & $\begin{array}{l}0.011 \mathrm{in} / \mathrm{day} \\
0.0279 \mathrm{~cm} / \mathrm{day}\end{array}$ & $\begin{array}{l}0.012 \mathrm{in} / \mathrm{day} \\
0.0305 \mathrm{~cm} / \mathrm{day}\end{array}$ & $\begin{array}{l}0.019 \mathrm{in} / \mathrm{day} \\
0.0483 \mathrm{~cm} / \mathrm{day}\end{array}$ & $\begin{array}{l}0.1 \mathrm{in} / \mathrm{day} \\
0.254 \mathrm{~cm} / \mathrm{day}\end{array}$ \\
\hline
\end{tabular}

DSSF = double-thell slurry feed

DSS = double-sholl slurry

CC = concentrated complexants

GRE = gas release event.

-Reaulta for tank 101-SY are prior to pump installation in July 1993. 
The SY farm tanks contain concentrated complexants (CC) which have more total organic carbon (TOC) than those with double-shell slurry (DSS) and double-shell slurry feed (DSSF). This could be a factor promoting the substantial GREs in tank 101-SY except that tank 103-SY, which al so contains CC, appears to behave similarly to the other small GRE tanks. All the tanks appear to have a convective layer and a nonconvective layer, although the nonconvective layer in 101-SY may be 1.5 to 2 times larger.

A11 of these tanks generate and accumulate gas, as evidenced by the surface level rise rate and periodic releases of the gas as shown by the crust drops (and gas monitor in tank 101-SY). However, the maximum crust drop in $101-5 Y$ is 3 to 5 times that of the other tanks, indicative of much larger gas releases. This is consistent with the surface rise rates which are a measure of the slurry gas accumulation rates in the nonconvective region. The GRE also may cause a pressure increase in the tank dome space and tank 101-SY pressure has occasionally risen above atmosphere pressure. A11 of the other tanks have remained below atmospheric pressure.

All the tanks appear to have a floating crust on the waste surface, although the last photographs were taken in the late 1980's. (Except for tank 101-SY which has recent video observations showing crust behavior.) Based on tank 101-SY experience, the crusts are believed to be structurally weak and unable to trap any sizable amount of gas underneath. All the flammable gas tank crusts should have approximately the same water content as tank 101-sY. A crust water content of $10 \%$ is selected for the crust burn analysis which is believed to be conservative since measurements in 101-SY show the crust is likely to contain much more.

Crust energetics for these tanks are based on adiabatic calorimetry tests for material from tank 101-SY but the exothermic energy and kinetic rates are doubled to ensure the energetics used in the analyses are bounding. Chemical analyses for DSS and DSSF waste indicate they have $1 / 5$ or less TOC than tank 101-SY. Since exothermic energy should be related to the TOC present for waste forms that have similar compositions, doubling the energy release is conservative but does provide extra margin till the tanks are sampled and calorimetry tests can be performed to confirm this is bounding.

The slurry gas composition is chosen using measured values from tank 101-SY. Two gas compositions are selected: a best estimate mixture which includes ammonia and methane and a conservative mixture of similar gases but that also allows more margin for uncertainties. The amount of gas released to the air in the dome space is based on the maximum observed 24 hour crust drops. The instantaneous release assumption is shown to result in predicted concentrations in tank 101-SY which exceed those observed. Results for other tanks are expected to be similarly conservative.

If the released slurry gas is completely mixed with the available air in the dome, it is not combustible. The time required for dilution of slurry gas release in a GRE was investigated parametrically with the GOTHIC code (Wood 1994). The effects of slurry gas release time and release area were examined parametrically. Time at risk, defined as the total time any volume node in the tank contains gas at a flammable concentration, was determined to be about 112 minutes for the limiting case. A time of 200 minutes, or $3.8 \times 10^{-4} \mathrm{yr} / \mathrm{yr}$, was used in the risk evaluation. 
The mixing simulations show that only a small amount of slurry gas is present in the tank at concentrations above the mjxed average. For example, for tank 104-AN, using a dome volume of 47,700 $\mathrm{ft}^{3}$ and a gas release of $3,600 \mathrm{ft}^{3}$, mixing studies show less than $200 \mathrm{ft}^{3}$ at $\mathrm{fl}$ ammable gas concentrations above $4 \%$ fuel gas. The remaining volume is below the LFL. The $200 \mathrm{ft}^{3}$ would contain less than $25 \mathrm{ft}^{3}$ of undiluted slurry gas. Burning this volume of slurry gas would result in a pressure of $0.151 \mathrm{bf} / \mathrm{in}^{2}$ in tank 104-AN. The gas release value of $3,600 \mathrm{ft}^{3}$ is a $26 \%$ excess over the historical maximum release that occurred over 3 days. For the remaining tanks in this group, the margin of the analyzed release of $3,600 \mathrm{ft}^{3}$ over the maximum historical releases range from 86 to $163 \%$. Thus, the actual risk associated with these tanks is much lower than suggested by the bounding risk evaluation provided in this report.

Burn pressures should be recalculated using flammable gas concentrations and spatial distributions predicted by the mixing studies when slurry gas release characteristics have been verified. In the meantime, a plume burn model based on incomplete mixing has been assumed to provide margins for uncertainties and to compensate for the lack of actual gas release characteristics.

In calculating tank pressure from postulated slurry gas burns, all of the gas is burned. With gas concentrations as described above, only a fraction of the gas inventory is likely to burn. Lean hydrogen mixtures produce pressure well below the adiabatic burn pressure because downward flame propagation cannot occur. Cashdollar et al. (1993) showed that a 5\% hydrogen-nitrous oxide stoichiometric mixture produced only about $40 \%$ of the adiabatic burn pressure. This characteristic has not been applied in this hazard assessment because DSTs have sufficient structural capability to readily withstand adiabatic burn pressures from the postulated burn events. However, lean burn situations should be investigated, particularly for applications to single-shell tank risk evaluation.

Calculated results from the best estimate assumptions show the heat produced by crust reactions is 1 ess than $0.5 \%$ of the total heat energy transferred to the crust from the burning plume. The conservative estimate calculations, selected to provide a bounding case for all these tanks, produces more reaction. The chemical heat produced in the crust adds about $30 \%$ to the heat transferred from the heated plume. Still, the chemical reactions are limited to 2 to $3 \mathrm{~mm}$ of the crust thickness and no propagating reaction occurs.

Margins are quantified showing the added energy and rates needed to cause a propagating reaction in crust. If the chemical reaction rates are twice as fast as those in crust from tank 101-SY, a propagating reaction will not occur unless the exothermic energy release is greater than 2.75 times that of tank 101-SY. Actual rates and energies for tanks 101-AW, 103-AN, 104-AN, and 105-AN are expected to be less than the 101-SY values because the TOC for these tanks is about $1 / 5$ that of 101-SY, giving even more margin.

In the bounding risk evaluation, the entire slurry gas release was assumed to burn adiabatically, producing tank pressures as shown in Table 2-2 for unvented tanks. These pressures are all below the DST capability of 55 psig. 
The radiological source terms resulting from the postulated gas burns consist of thermal and mechanical components and part of the ventilation system inventory, as assumed in previous waste tank hazards evaluations. Radiological dose consequences are calculated using standard Hanford Site techniques. Dose consequences are summarized in Table 2-3. The limits cited there are from WHC-CM-4-46 (WHC 1993). The bone surface doses are controlling but fall within the same likelihood categories as the whole body doses. The site boundary dose consequences are very low and are within the anticipated accident category.

Ignition source frequency is shown Table 2-4. These values conservatively assume the occurrence of a spark is identical with the occurrence of an earthquake or a lightning strike; this is not the case.

Table 2-2. Slurry Gas Burn Pressures.

\begin{tabular}{|c|c|c|c|}
\hline Tank & Free volume, $\mathrm{ft}^{3}$ & $\begin{array}{c}\text { Best estimate, } \\
\text { psig }\end{array}$ & $\begin{array}{c}\text { Conservative } \\
\text { bounding, psig }\end{array}$ \\
\hline 103 -SY & 87,609 & 5 & 7 \\
\hline $101-$ AW & 37,634 & 12 & 17 \\
\hline $103-$ AN & 61,100 & 10 & 14 \\
\hline $104-A N$ & 46,010 & 20 & 28 \\
\hline $105-A N$ & 37,360 & 13 & 17 \\
\hline
\end{tabular}

Table 2-3. Radiological Dose Consequences, EDE, rem.

\begin{tabular}{|c|c|c|c|}
\hline Location & Best estimate & $\begin{array}{c}\text { Conservative } \\
\text { bounding }\end{array}$ & $\begin{array}{c}\text { Limits } \\
10^{-\frac{4}{4}} \text { to } 10^{-6} \\
\text { 1ike1 ihood }\end{array}$ \\
\hline $100 \mathrm{~m}$ & 4.1 & 11 & 25 to 100 \\
\hline Site boundary & $1.7 \mathrm{E}-3$ & $4.7 \mathrm{E}-3$ & 4 to 25 \\
\hline
\end{tabular}

$E D E=$ Effective dose equivalent. 
Table 2-4. Ignition Source Frequency.

\begin{tabular}{|c|c|}
\hline Source & Events/yr/tank \\
\hline In-tank instrumentation & $<1 \mathrm{E}-6$ \\
\hline Seismic & $<1.7 \mathrm{E}-4$ \\
\hline Lightning & $<4.7 \mathrm{E}-4$ \\
\hline
\end{tabular}

Combining the length of time a flammable gas mixture is present in a tank with the most frequent ignition source results in a burn frequency of $1.8 \mathrm{E}-7 / \mathrm{yr} /$ tank. With five tanks in this group, flammable burn frequency is less than $1 \mathrm{E}-6 / \mathrm{yr}$. Thus, the risk acceptance guidelines are met with large margins to accommodate unexpected parameter increases.

A work window for tank intrusive activities is not required for this group of tanks. As discussed above, mixing studies indicate that local dome regions at concentrations above the LFL would be very small and would exist for a limited time only. Moreover, none of the GREs occurring up to the present time show a positive pressure in any of these tanks. The maximum postulated flammable gas burn is smaller than the burn volume postulated and accepted for tank 101-SY when that tank had a window. Should a GRE occur and somehow be ignited, tank pressure is not likely to exceed the high-efficiency particulate air (HEPA) filter failure pressure. The work activity controls, including time of intrusion control established in the safety basis for activities in double-she11 flammable gas watch list tanks (Van Vieet 1994) should continue to be applied.

Appendix $H$ has been created to summarize the conservative features of this assessment and, if possible, to indicate margins. Further details are available in the body of the report. 
WHC-SD-WM-SAR-064, Rev. 0

This page intentionally left blank. 


\subsection{WASTE CHARACTERIZATION}

Waste characterization should include a description of the chemical composition, physical properties, and radionuclide characteristics. The chemical composition is used to understand its nature and to compare the waste in different tanks. Physical properties are needed for crust heating calculations while radionuclide characteristics are used to establish the source term for the dose calculations.

Actual sample data from this set of tanks are quite limited. Only tanks 103-AN and 103-SY have been core sampled. Much of the characterization discussion consists of comparing different tanks and highlighting similarities and differences. This is because most of the knowledge about phenomena and properties have come from the program involving tank 101-SY. Many of these same mechanisms operate in other flammable gas tanks. Uncertainty margins have been applied to support the goal of obtaining conservative results.

\subsection{CHEMICAL PROPERTIES}

The DSTs considered in this report were constructed in the early 1980's and began receiving waste about 1981 or 1982. Transfers occurred in and out of the tanks for the next several years as various tanks were used for. evaporator feed or storage of evaporator products. The last major fills occurred about 1985 or 1986 with only small water additions to the tanks since (Brager 1994). Three types of waste are now stored in these tanks as defined in Table $3-1$.

Table 3-1. Double-Shell Tank Waste Descriptions.

\begin{tabular}{|l|l|}
\hline \multicolumn{1}{|c|}{ Waste type } & \multicolumn{1}{|c|}{ Description } \\
\hline CC & $\begin{array}{l}\text { Concentrated product from the evaporation of } \\
\text { dilute complexed waste. This is characterized by } \\
\text { a high organic carbon content, including organi.c } \\
\text { complexants such as EDTA, citric acid, and HEDTA }\end{array}$ \\
\hline DSS & $\begin{array}{l}\text { Waste concentrated until it exceeds the sodium } \\
\text { aluminate saturation boundary in the evaporator }\end{array}$ \\
\hline DSSF & $\begin{array}{l}\text { Waste concentrated just before reaching the } \\
\text { sodium aluminate saturation boundary in the } \\
\text { evaporator }\end{array}$ \\
DSS $=$ double-shell complexants \\
DSSF $=$ double-shell slurry feed \\
EDTA $=$ ethylenediaminetetra-acetic acid \\
HEDTA $=$ hydroxyethyl-ethylenediaminetriacetic acid.
\end{tabular}


The waste type in each tank is shown in Table 3-2.

Table 3-2. Waste Type and Volume by Tank.

\begin{tabular}{|l|l|l|l|l|}
\hline \multicolumn{1}{|c|}{ Tank ID } & Last major fi11 & Waste type & $\begin{array}{c}\text { Total waste, } \\
10^{6} \text { gal }\end{array}$ & $\begin{array}{c}\text { Supernatant, } \\
10^{6} \text { gal }\end{array}$ \\
\hline $101-$ AW & $7-25-86$ & DSSF & 1.141 & 1.06 \\
\hline $103-$ AN & $2-23-86$ & DSS & 0.954 & 0.016 \\
\hline $104-$ AN & $4-26-85$ & DSSF & 1.057 & 0.80 \\
\hline $105-$ AN & $4-25-85$ & DSS & 1.1129 & 1.13 \\
\hline $103-$ SY & $8-13-88$ & CC & 0.743 & 0.40 \\
\hline $101-S Y$ & $11-6-80$ & CC & 1.101 & 0.42 \\
\hline
\end{tabular}

The tank design capacity is $1.16 \times 10^{6}$ gal; however, the available capacity is defined as $1.14 \times 10^{6} \mathrm{gal}$ to allow for volumetric expansion. Hence, most of these tanks are nearly full. The waste is highly caustic, having a pH of 13 to 13.5 (Brager 1994). It consists of supernatant liquid, which circulates by natural convection in the upper portion of the tank (convective layer), and precipitated solids and sludge in a lower layer. The higher temperatures in the lower portion of the tank indicate this region does not normally circulate and is called the nonconvective (NC) region. Some characteristics of the NC and convective layers are shown in Table 3-3.

Table 3-3. Waste Characterization by Tank.

\begin{tabular}{|c|c|c|c|c|c|c|c|}
\hline \multirow{2}{*}{ Tank ID } & \multirow{2}{*}{$\begin{array}{c}\text { Waste } \\
\text { height } \\
\text { (in.) }\end{array}$} & \multirow{2}{*}{$\begin{array}{c}\text { NC layer } \\
\text { depth (in.) }\end{array}$} & \multicolumn{2}{|c|}{$S p G r$} & \multicolumn{2}{|c|}{ TOC (\%) } & \multirow{2}{*}{$\begin{array}{l}\text { Temperature } \\
\text { average }\left({ }^{\circ} \mathrm{F}\right)\end{array}$} \\
\hline & & & Conv & NC & Conv & NC & \\
\hline 101-AW & 409 & 125 & 1.56 & 1.7 & 0.28 & -- & $95-102$ \\
\hline 103-AN & 346 & 150 & 1.48 & 1.8 & 0.23 & 0.46 & $105-112$ \\
\hline 104-AN & 387 & 150 & 1.46 & -- & 0.29 & -- & $104-116$ \\
\hline $105-\mathrm{AN}$ & 411 & 150 & 1.53 & $\overline{--}$ & 0.27 & -- & $98-106$ \\
\hline $103-5 Y$ & 274 & 128 & $1.49^{1}$ & $1.69^{1}$ & 1.3 & 3.5 & $95-105$ \\
\hline $101-S Y$ & 408 & 200 to 250 & 1.49 & 1.69 & 1.25 & 1.91 & $110-120$ \\
\hline
\end{tabular}

${ }^{1}$ Assumed same as tank 101-SY.

The data in Tables 3-2 and 3-3 came from a variety of sources, including Brager (1994), Hanlon (1994), Reynolds (1994), Wilkins (1994), Van Vleet (1993), Hendrickson and Conner (1994), and Herting et a1. (1992). 
WHC-SD-WM-SAR-064, Rev. 0

The values in these tables are intended to be representative as there may be differences in values between sources as different laboratory analyses were used. The main differences between the waste in these tanks may be summarized as follows: the SY farm tanks contain a relatively large amount of CC, whereas the other tanks mainly contain DSS and DSSF.

The SY farm tanks have TOC values that are about a factor of 5 larger than the other tanks. For this reason calorimetry samples tested for tank 101-SY should bound the exothermic energy of material in these other tanks. This will be discussed further in Section 7.0. The operating temperatures for the tanks shown in Table 3-3 range from $95^{\circ} \mathrm{F}$ to $116^{\circ} \mathrm{F}$, depending on season. Tank 101-SY operates about $10^{\circ} \mathrm{F}$ higher than most other tanks in this group.

The chemical inventory for tanks has been complied by Van Vleet (1993) and a portion of the data for the tanks of interest has been reformed into Table 3-4. These are the total tank inventory of the chemical components expressed in grams. The flammable gas tanks all appear to have similar components, so in order to focus on this more closely, the chemical mass fractions were calculated and the most significant species are shown in Table 3-5. The major components which appear in all the tanks are in approximately similar proportions. It is not possible to predict waste behavior from knowing these components, but it is probable that, as a class, they will behave in a similar fashion.

Table 3-4. Estimated Chemical Waste Tank Inventory (Van Vleet 1993). (sheet 1 of 2)

\begin{tabular}{|c|c|c|c|c|c|c|}
\hline \multirow[b]{2}{*}{ Component } & \multicolumn{6}{|c|}{ Tank contents ( $g /$ tank) } \\
\hline & $\begin{array}{l}A W-101 \\
(6 / 90)^{a}\end{array}$ & $\begin{array}{l}A N-103^{b} \\
(2 / 90)^{a}\end{array}$ & $\begin{array}{l}\text { AN-104 } \\
(7 / 84)^{a}\end{array}$ & $\begin{array}{c}A N-105 \\
(11 / 84)^{a}\end{array}$ & $\begin{array}{l}S Y-101 \\
(5 / 91)^{a}\end{array}$ & $\begin{array}{l}S Y-103 \\
(6 / 85)^{a}\end{array}$ \\
\hline$\overline{\mathrm{Ag}}$ & $<1.4 E+05$ & $<5.7 E+04$ & - & -- & -- & -- \\
\hline$\overline{A 1}$ & $1.2 E+08$ & $2.08 E+08$ & $6.4 E+07$ & $1.1 E+08$ & $1.9 E+08$ & $1.2 E+08$ \\
\hline As & $<4.3 E+01$ & $<5.7 E+05$ & - & - & - & $\overline{--}$ \\
\hline $\bar{B}$ & - & $\overline{--}$ & - & -- & -- & $2.1 E+05$ \\
\hline $\mathrm{Ba}$ & $<4.0 E+04$ & $<5.7 E+04$ & - & -- & -- & - \\
\hline$\overline{\mathrm{Be}}$ & - & $<5.7 E+04$ & -- & -- & - & - \\
\hline$\overline{\mathrm{Bi}}$ & $<5.2 E+05$ & $<1.7 E+06$ & - & - & $\overline{--}$ & - \\
\hline $\mathrm{CN}^{-}$ & $1.2 E+05$ & $1.2 E+05$ & - & - & $9.7 \mathrm{E}+05$ & -- \\
\hline $\mathrm{CO}_{3}^{-}$ & $5.3 E+07$ & $3.2 E+07$ & $2.2 E+07$ & $1.1 E+08$ & - & $8.2 E+07$ \\
\hline $\overrightarrow{\mathrm{Ca}}$ & $1.4 E+05$ & $3.1 E+05$ & - & - & $4.0 E+06$ & $6.4 E+05$ \\
\hline Cd & $<5.2 E+03$ & $5.7 E+04$ & -- & - & -- & - \\
\hline $\mathrm{Cl}^{\circ}$ & $2.2 E+07$ & $3.4 E+07$ & - & $2.7 E+06$ & $4.9 E+07$ & $2.6 E+07$ \\
\hline $\mathrm{Cr}$ & $6.9 E+05$ & $3.0 E+06$ & $8.9 E+05$ & -- & $2.2 E+07$ & $4.4 E+06$ \\
\hline $\mathrm{Cu}$ & $1.0 E+05$ & $4.3 E+04$ & - & -- & - & $1.8 E+04$ \\
\hline EDTA & - & $3.0 \mathrm{E}+05$ & -- & -- & - & $1.3 E+07$ \\
\hline
\end{tabular}


WHC-SD-WM-SAR-064, Rev. 0

Table 3-4. Estimated Chemical Waste Tank Inventory (Van Vleet 1993). (sheet 2 of 2)

\begin{tabular}{|c|c|c|c|c|c|c|}
\hline \multirow[b]{2}{*}{ Component } & \multicolumn{6}{|c|}{ Tank contents ( $\mathrm{g} / \operatorname{tank})$} \\
\hline & $\begin{array}{l}A W-101 \\
(6 / 90)^{\mathrm{a}}\end{array}$ & $\begin{array}{l}A N-103^{b} \\
(2 / 90)^{a}\end{array}$ & $\begin{array}{l}A N-104 \\
(7 / 84)^{\mathrm{B}}\end{array}$ & $\begin{array}{c}A N-105 \\
(11 / 84)^{a}\end{array}$ & $\begin{array}{l}\text { SY-101 } \\
(5 / 91)^{\mathrm{a}}\end{array}$ & $\begin{array}{l}\text { SY-103 } \\
(6 / 85)^{\mathrm{a}}\end{array}$ \\
\hline$F^{-}$ & $<3.3 E+05$ & $2.6 \mathrm{E}+06$ & -- & -- & $7.0 E+05$ & $\overline{--}$ \\
\hline $\mathrm{Fe}$ & $<1.9 E+05$ & $2.5 E+05$ & $1.5 E+04$ & $\overline{--}$ & $2.2 E+06$ & $\overline{--}$ \\
\hline HEDTA & -- & $\overline{--}$ & -- & $\overline{--}$ & $\overline{--}$ & $<1.2 E+06$ \\
\hline $\mathrm{Hg}$ & $<6.8 E+02$ & $5.7 E+04$ & -- & $\overline{--}$ & $\overline{--}$ & $4.1 E+03$ \\
\hline $\mathrm{K}$ & $1.8 \mathrm{E}+08$ & $5.4 \mathrm{E}+07$ & -- & $1.5 E+07$ & $1.9 E+07$ & $1.0 E+07$ \\
\hline $\mathrm{Mg}$ & $2.3 E+05$ & $1.0 \mathrm{E}+05$ & $\therefore$ & -- & -- & $3.1 E+03$ \\
\hline$M n$ & $1.1 E+05$ & $1.0 E+05$ & -- & -- & - & -- \\
\hline Mo & $2.5 \mathrm{E}+05$ & $3.1 \mathrm{E}+05$ & $\overline{--}$ & $\overline{--}$ & $4.2 E+05$ & $2.3 E+05$ \\
\hline $\mathrm{NH}_{3}$ & $1.1 E+06$ & -- & $\overline{-}$ & $7.1 \mathrm{E}+05$ & $1.2 E+07$ & -- \\
\hline $\mathrm{NO}_{2}^{-}$ & $4.4 E+08$ & $4.9 \mathrm{E}+08$ & $1.3 \mathrm{E}+08$ & $2.6 E+08$ & $6.5 E+08$ & $2.7 E+08$ \\
\hline $\mathrm{NO}_{3}$ & $9.2 \mathrm{E}+08$ & $5.7 E+08$ & $2.2 E+08$ & $5.6 E+08$ & $6.9 E+08$ & $3.4 \mathrm{E}+08$ \\
\hline $\mathrm{Na}$ & $9.9 E+08$ & $1.2 E+09$ & $2.4 E+08$ & $7.6 \mathrm{E}+08$ & $1.2 E+09$ & $5.7 E+08$ \\
\hline $\mathrm{Ni}$ & $\overline{--}$ & $<8.5 E+04$ & $\overline{--}$ & $\overline{--}$ & $1.1 E+06$ & $5.1 E+04$ \\
\hline $\mathrm{OH}^{-}$ & $3.7 E+08$ & $3.5 E+08$ & $8.9 \mathrm{E}+07$ & $1.6 \mathrm{E}+08$ & $1.4 \mathrm{E}+08$ & $5.5 E+07$ \\
\hline$P$ & - & -- & $\overline{--}$ & -- & -- & $9.5 E+06$ \\
\hline $\mathrm{PO}_{4-}$ & $9.1 E+06$ & $3.3 E+06$ & $8.7 \mathrm{E}+05$ & $6.0 \mathrm{E}+06$ & $4.1 E+07$ & $1.9 E+07$ \\
\hline $\mathrm{Pb}$ & $<1.3 E+06$ & $2.6 E+05$ & -- & -- & -- & -- \\
\hline $\mathrm{Pu}$ & $\overline{--}$ & -- & $2.2 E+02$ & -- & -- & -- \\
\hline $\mathrm{SO}_{4--}$ & $4.4 E+06$ & $5.7 E+06$ & $2.0 E+06$ & -- & $2.6 \mathrm{E}+07$ & $<1.7 E+07$ \\
\hline$S b$ & -- & $<5.7 \mathrm{E}+05$ & -- & -- & -- & -- \\
\hline $\mathrm{Se}$ & $1.4 E+02$ & $<7.4 E+05$ & -- & -- & -- & -- \\
\hline$S i$ & $<5.3 E+05$ & $9.7 E+0.5$ & - & -- & -- & $1.2 \mathrm{E}+05$ \\
\hline TOC & $1.1 \mathrm{E}+07$ & $2.6 \mathrm{E}+07$ & $5.0 E+06$ & $1.4 E+07$ & $9.5 \mathrm{E}+07$ & $9.2 \mathrm{E}+07$ \\
\hline $\mathrm{Ti}$ & $<2.0 E+04$ & $<5.7 E+04$ & -- & - & $\overline{--}$ & -- \\
\hline$U$ & $9.6 \mathrm{E}+05$ & $4.4 E+05$ & -- & -- & -- & -- \\
\hline $\mathrm{V}$ & -- & $<5.7 \mathrm{E}+04$ & -- & -- & -- & -- \\
\hline$W$ & -- & $7.4 E+05$ & -- & -- & -- & -- \\
\hline $\mathrm{Zn}$ & $<1.4 \mathrm{E}+06$ & $1.7 \mathrm{E}+05$ & - & -- & $3.6 \mathrm{E}+05$ & -- \\
\hline $\mathrm{Zr}$ & $<2.2 E+05$ & $<8.5 E+04$ & - & -- & -- & -- \\
\hline
\end{tabular}

${ }^{a}$ Sample date for tank.

bslurry only. 
WHC-SD-WM-SAR-064, Rev. 0

Table 3-5. Weight Fractions of More Significant Species.

\begin{tabular}{|c|c|c|c|c|c|c|}
\hline \multirow{2}{*}{ Chemical } & \multicolumn{7}{|c|}{ Tank, chemical weight fraction } \\
\cline { 2 - 7 } & $101-\mathrm{AW}$ & $103-\mathrm{AN}$ & $104-\mathrm{AN}$ & $105-\mathrm{AN}$ & $101-\mathrm{SY}$ & $103-\mathrm{SY}$ \\
\hline $\mathrm{Al}$ & 0.038 & 0.067 & 0.083 & 0.055 & 0.060 & 0.074 \\
\hline $\mathrm{CO}_{3}^{--}$ & 0.017 & 0.011 & 0.028 & 0.055 & -- & 0.050 \\
\hline $\mathrm{NO}_{2}^{-}$ & 0.141 & 0.164 & 0.168 & 0.130 & 0.207 & 0.166 \\
\hline $\mathrm{NO}_{3}^{-}$ & 0.294 & 0.191 & 0.284 & 0.280 & 0.219 & 0.209 \\
\hline $\mathrm{Na}$ & 0.317 & 0.403 & 0.310 & 0.380 & 0.382 & 0.350 \\
\hline $\mathrm{OH}^{-}$ & 0.118 & 0.117 & 0.115 & 0.080 & 0.045 & 0.034 \\
\hline $\mathrm{TOC}^{-}$ & 0.004 & 0.009 & 0.006 & 0.007 & 0.030 & 0.056 \\
\hline Others & 0.072 & 0.037 & 0.005 & 0.012 & 0.057 & 0.062 \\
\hline
\end{tabular}

\subsection{THERMAL PROPERTIES}

Thermophysical properties are needed for the transient temperature calculations performed later.

Crust density is unknown. A value has been assigned on the basis of density measurements made on convective liquid for tank 101-SY

(Herting et al. 1992). The bulk convective liquid density was measured to be $1.54 \mathrm{~g} / \mathrm{cm}^{3}$. This is consistent with values found for the convective region of the other flammable gas tanks shown in Table 3-3. This was reduced to $1.5 \mathrm{~g} / \mathrm{cm}^{3}\left(941 \mathrm{~b} / \mathrm{ft}^{3}\right)$ to recognize the fact that the crust is less dense than the liquid in which it floats.

Thermal conductivity data are obtained from a group of tank samples, al though none came from the tanks considered in this report. The value of $0.433 \mathrm{~W} / \mathrm{m} \mathrm{K}$ used in this assessment is near the minimum measured, which gives conservative results (Fox et a1. 1993).

The specific heat for crust was estimated using Kopp's Rule for the constituents in the crust as described in Appendix A of Fox et al. (1992). The value arrived at for relatively dry crust was $0.3 \mathrm{cal} / \mathrm{g}{ }^{\circ} \mathrm{C}$.

The thermophysical properties use in the conduction analysis are shown in Table 3-6.

\subsection{RADIONUCLIDE CHARACTERIZATION}

The best estimate radioactive inventories for all the tanks in this assessment are tabulated and discussed in the next section. Then, a bounding inventory is developed which is used later for the dose consequences evaluation. 
Table 3-6. Crust Thermophysical Properties.

\begin{tabular}{|l|c|}
\hline \multicolumn{1}{|c|}{ Property } & Value \\
\hline Thermal conductivity & $\begin{array}{c}0.433 \mathrm{~W} / \mathrm{m} \mathrm{K} \\
\left(0.25 \mathrm{Btu} / \mathrm{ft} \mathrm{hr}{ }^{\circ} \mathrm{F}\right)\end{array}$ \\
\hline Specific heat & $\begin{array}{c}0.3 \mathrm{cal} / \mathrm{g}{ }^{\circ} \mathrm{C} \\
\left(0.3 \mathrm{Btu} / \mathrm{Tb}{ }^{\circ} \mathrm{F}\right)\end{array}$ \\
\hline Density & $\begin{array}{c}1.5 \mathrm{~g} / \mathrm{cm}^{3} \\
\left(94 \mathrm{lb} / \mathrm{ft}^{3}\right)\end{array}$ \\
\hline
\end{tabular}

\subsubsection{Radjonuclide Inventories}

Best estimates of radionuclide inventories in this group of double-she11 flammable gas tanks are given in Table 3-7. Tank 103-SY was core-sampled in 1986 with emphasis on determination of transuranics for retrieval and longterm disposal (Fow et a7. 1986). When the tank was sampled, it contained 572,700 gal of waste; subsequent7y, 131,000 gal of interstitial liquid and water from tank 104-SX was added (Fox et al. 1993). An analysis of tank 104-SX is available in Fox et al. (1993), and the data were combined with the fow et a7. (1986) analysis to arrive at the values given in Table 3-7.

The data for tank 101-AW were extracted from a compilation by Hendrickson (1991), quoted by WiTkins (1994). The tank was sampled in June 1990. Twelve 100-mL bottle-on-a-string samples were taken from three randomly selected risers. Initial results suggested the tank contents were homogeneous. The twelve samples were mixed to make a composite providing the results in Table $3-7$.

Tank 103-AN was core sampled during December 1986. Reynolds (1994) described the results as follows:

"The surface leve1 was about 334.5 in. during December 1986. Norma1 paraffin hydrocarbon was used as a hydrostatic fluid during core sampling. Eighteen segments were recovered. Segment 1 contained only 4 in. of waste. Segment 18 (at the bottom of the tank) contained $14.25 \mathrm{in}$. of waste as expected. A hard layer was encountered at the segment 12 level (approximately 110 in.). Segments 2 through 10 and the upper portion of segment 11 contained a less dense slurry. A slurry of greater density was encountered at segments 12 through 18 and the lower portion of segment 11 . The midpoint of segment 11 should be at 138 in. A composite of the core sample was sent to Pacific Northwest Laboratory (PNL) for chemical composition."

The compilation in Table 3-7 for tank 103-AN is as reported in Reynolds (1994). 
Tanks 104-AN and 105-AN were not core sampled. However, data are available on evaporator slurry transferred to these tanks. The grout performance assessment (Kincaid et al. 1993) used these data to prepare the radionuclide inventory quoted in Table 3-7, except for Am-241, as discussed below.

Table 3-7. Radionuclide Concentrations in Double-Shell Waste Tanks $(\mu \mathrm{Ci} / \mathrm{L})$.

\begin{tabular}{|l|c|c|c|c|c|}
\hline \multicolumn{1}{|c|}{ Isotope } & $103-S Y^{(1)}$ & $101-\mathrm{AW}^{(2)}$ & $103 \mathrm{AN}^{(3)}$ & $104 \mathrm{AN}^{(4)}$ & $105 \mathrm{AN}^{(4)}$ \\
\hline Sr-90 & $N R$ & $1.08 \mathrm{E}+3$ & $2.44 \mathrm{E}+4$ & $9.84 \mathrm{E}+3$ & $3.23 \mathrm{E}+3$ \\
\hline $\mathrm{Tc}-99$ & $\mathrm{NR}$ & $1.52 \mathrm{E}+2$ & $1.08 \mathrm{E}+2$ & $\mathrm{NR}$ & $\mathrm{NR}$ \\
\hline $\mathrm{I}-129$ & $\mathrm{NR}$ & $3.03 \mathrm{E}-1$ & $1.42 \mathrm{E}-1$ & $\mathrm{NR}$ & $\mathrm{NR}$ \\
\hline $\mathrm{Cs}-137$ & $6.82 \mathrm{E}+5$ & $5.20 \mathrm{E}+5$ & $2.55 \mathrm{E}+5$ & $9.56 \mathrm{E}+5$ & $5.04 \mathrm{E}+5$ \\
\hline $\mathrm{Np}-237$ & $\mathrm{NR}$ & $2.16 \mathrm{E}+0$ & $2.55 \mathrm{E}-2$ & $\mathrm{NR}$ & $\mathrm{NR}$ \\
\hline $\mathrm{Pu}-239$ & $9.4 \mathrm{E}+1$ & $1.14 \mathrm{E}+0$ & $1.24 \mathrm{E}+0$ & $1.04 \mathrm{E}+1$ & $1.04 \mathrm{E}+1$ \\
\hline $\mathrm{Am}-241$ & $7.6 \mathrm{E}+2$ & $1.2 \mathrm{E}+0$ & $3.34 \mathrm{E}+0$ & $1.31 \mathrm{E}+3$ & $1.31 \mathrm{E}+3$ \\
\hline
\end{tabular}

$N R=$ Not reported.

Notes:

1. Fow et al. (1986), Table 4.1, mean of three distributed samples, based on 1986 core sample. Pu and Am concentration reduced by post-sampling transfer from 104-SX.

2. Wilkins (1994), Appendix A, mean of composite made from twelve 100-mL bottle-on-string samples from three risers, June 1990.

3. Reynolds (1994), Table A-6, composite of 18 core segments, sampled in December 1986.

4. Kincaid et a7. (1993), Table 1-2, based on analyses of evaporator slurry transferred to these tanks, decayed to 10/01/93. Am-241 concentration based on waste transfer records, see Appendix $B$.

The Am-241 concentration for tanks 104-AN and 105-AN is based on the waste transfer records and data on the radionuclide inventory in the waste transferred. Some of the waste transferred to 104-AN and 103-AN was reported to contain an Am-241 inventory which is unusually high and apparently erroneous. The questionable analysis pertains to 289,000 gal of evaporator slurry from the 84-3 campaign in 1984, analyzed as containing $1.14 \mathrm{E} 4 \mu \mathrm{Ci} / \mathrm{L}$ Am-241. When tank 103-AN was sampled in 1986, it contained 919,000 gal of which $193,000 \mathrm{gal}$ were from tank 104-AN. This represents $21 \%$ of the waste or a depth of nearly $6 \mathrm{ft}(0.21 \times 334.5 / 12=5.85 \mathrm{ft})$. The tank was sampled all the way to the bottom; a 6-ft-thick equivalent layer would be hard to miss in 
WHC-SD-WM-SAR-064, Rev. 0

a core drill sampling that extended to the bottom of the tank. The Am-241 content claimed for tank 104-AN was not found in this core drilling. A mass balance given in Appendix B of this report shows that the 103-AN sample analysis should have shown an Am-241 level three orders of magnitude higher than found if the 84-3 slurry analysis were correct. However, for this hazard evaluation, the high concentration was assumed to be correct, and 104-AN and 105-AN concentrations of $1.31 \mathrm{E} 3 \mu \mathrm{Ci} / \mathrm{L}$ resulted, as shown in Table 3-7. The calculations are given in Appendix B.

\subsubsection{Inventory for Radiological Dose Consequences Evaluation}

The source term is based on the radionuclide inventory in the surface crust covering the waste. For tank 10I-SY, the inventory was based on the arithmetic average of six actual crust samples. The radionuclide inventory was normalized to $10 \%$ water by weight as described in Appendix 5A, Simpson et al. (1993). Crust samples are not available from any of the other DSTs, so radionuclide concentration estimates were based on best available radiochemical analyses for other than crust regions. Those results are generally reported on a unit volume basis and were converted to a unit mass basis using the best available data on waste density and solids mass fractions. The values used are noted in the footnotes to Table 3-8. The inventories on a dry weight basis were adjusted to a $10 \%$ water bas is for consistency with the 101-SY crust treatment. The results are shown in Table 3-8. The highest inventory for each isotope was selected to form a composite crust composition applicable to all of the DSTs in this set. The composite crust inventory thus formed is shown in Table 3-9. Table 3-9 also shows a bounding composition which represents the highest crust concentrations known or predicted in all of the double-shell flammable gas tanks including 101-SY. In addition, the Cs-137 and Pu-239 concentrations were arbitrarily increased by $25 \%$ since the highest concentration of these two nuclides occurred in tanks not yet surface sampled (103-SY) or not sampled at all (104-AN). 
WHC-SD-WM-SAR-064, Rev. 0

Table 3-8. Crust Radionuclide Inventories $(\mu \mathrm{C} \mathrm{i} / \mathrm{g})$.

\begin{tabular}{|l|c|c|c|c|c|c|}
\hline Isotope & $101-S Y^{(1)}$ & $103-S Y^{(2)}$ & $101-\mathrm{AW}^{(3)}$ & $103 \mathrm{AN}^{(4)}$ & $104 \mathrm{AN}^{(5)}$ & $105 \mathrm{AN}^{(5)}$ \\
\hline Sr-90 & $4.1 \mathrm{E}+1$ & $\mathrm{NR}$ & $1.1 \mathrm{E}+0$ & $2.2 \mathrm{E}+1$ & $9.8 \mathrm{E}+0$ & $3.2 \mathrm{E}+0$ \\
\hline Tc-99 & $3.6 \mathrm{E}-1$ & $\mathrm{NR}$ & $1.6 \mathrm{E}-1$ & $9.5 \mathrm{E}-2$ & $\mathrm{NR}$ & $\mathrm{NR}$ \\
\hline $\mathrm{I}-129$ & $3.5 \mathrm{E}-1$ & $\mathrm{NR}$ & $3.1 \mathrm{E}-4$ & $1.3 \mathrm{E}-4$ & $\mathrm{NR}$ & $\mathrm{NR}$ \\
\hline $\mathrm{Cs}-137$ & $5.2 \mathrm{E}+2$ & $6.6 \mathrm{E}+2$ & $5.3 \mathrm{E}+2$ & $6.7 \mathrm{E}+2$ & $9.7 \mathrm{E} 2$ & $5.0 \mathrm{E2}$ \\
\hline $\mathrm{Np}-237$ & $6.1 \mathrm{E}-1$ & $\mathrm{NR}$ & $2.2 \mathrm{E}-3$ & $2.2 \mathrm{E}-5$ & $\mathrm{NR}$ & $\mathrm{NR}$ \\
\hline $\mathrm{Pu}-239$ & $1.9 \mathrm{E}-2$ & $7.4 \mathrm{E}-2$ & $1.1 \mathrm{E}-3$ & $1.1 \mathrm{E}-3$ & $1.0 \mathrm{E}-2$ & $1.0 \mathrm{E}-2$ \\
\hline $\mathrm{Am}-241$ & $1.8 \mathrm{E}-1$ & $6.0 \mathrm{E}-1$ & $1.2 \mathrm{E}-3$ & $3.0 \mathrm{E}-3$ & $1.4 \mathrm{E}+0$ & $1.4 \mathrm{E}+0$ \\
\hline
\end{tabular}

NR $=$ Not reported .

Notes:

1. Simpson et al. (1993), Table 5A-5, average of Window $C$ core crust samples, normalized to $10 \%$ water content.

2. Data from Table 5-1, this report, converted to solid crust with $10 \%$ water using average of measured density and assuming solids weight fraction of 0.6 .

3. Same as note 2 except measured solids fraction used.

4. Same as note 2 except density and solids fraction calculated from composite of core segments.

5. Same as note 2 except assumed waste density $=1.5$, solids weight fraction $=0.6$. 
Table 3-9. Maximum Crust Radionuclide Concentration $(\mu \mathrm{Ci} / \mathrm{g})$.

\begin{tabular}{|c|c|c|c|}
\hline Isotope & $101-S Y$ & Composite $^{(1)}$ & Bounding composite $^{(2)}$ \\
\hline Sr-90 & $4.1 \mathrm{E}+1$ & $2.2 \mathrm{E}+1$ & $4.1 \mathrm{E}+1$ \\
\hline Tc-99 & $3.6 \mathrm{E}-1$ & $1.6 \mathrm{E}-1$ & $3.6 \mathrm{E}-1$ \\
\hline $\mathrm{I}-129$ & $3.5 \mathrm{E}-1$ & $3.1 \mathrm{E}-4$ & $3.5 \mathrm{E}-1$ \\
\hline $\mathrm{Cs}-137$ & $5.2 \mathrm{E}+2$ & $9.7 \mathrm{E}+2$ & $1.2 \mathrm{E}+3$ \\
\hline $\mathrm{Np}-237$ & $6.1 \mathrm{E}-1$ & $2.2 \mathrm{E}-3$ & $6.1 \mathrm{E}-1$ \\
\hline $\mathrm{Pu}-239$ & $1.9 \mathrm{E}-2$ & $7.4 \mathrm{E}-2$ & $9.3 \mathrm{E}-2$ \\
\hline Am-241 & $1.8 \mathrm{E}-1$ & $1.4 \mathrm{EO}$ & $1.4 \mathrm{E} 0$ \\
\hline
\end{tabular}

Notes:

1. Maximum value found in any of the tanks in this group.

2. Tank 101-SY crust composition was used when concentration was greater than composite value. Cs-137 and Pu-239 were increased by $25 \%$ to form the bounding composite. Am-241 not increased because it is already considered excessively high. 
WHC-SD-WM-SAR-064, Rev. 0

\subsection{GAS CHARACTERIZATION}

The slurry gas is the most important factor in the hazard assessment. Its composition, flammability, and concentration control whether an ignition source creates a serious problem or is a non-event. Gas accumulation occurs in the lower region of the tank where large quantities of precipitated solids exist. The overlying convective region is mostly liquid and stores gas only as very small bubbles and dissolved gas. Because the solubility of flammable gas in liquids is low, comparatively little gas accumulates in the convective region. (Ammonia, when it exists, may be an exception.) A gas release event (GRE) occurs when enough gas has collected in the nonconvective region to reduce its density to less than the overlying convective region. This causes an instability and the gas-filled sludge breaks loose and rises to the top, releasing its trapped gas.

Some discussion is needed on how a hazards assessment should select the maximum size gas release for the flammable gas tanks considered here. One approach might be to apply a rollover model that has been developed for tank 101-SY. (Note: While it should be obvious, we would like to point out the following discussion of rollover events for 101-sY only applies before mixer pump operation started in July 1993.) This could either be a neutralbuoyancy or a Rayleigh-Taylor model (LANL 1994). However, LANL personnel have made the following observation by Kubic in Johnson (1994):
"Bounding consequences analysis have been based on the neutral buoyancy model assumption that the worst-case consequences in many of the Double-Shell Gas Watch List tanks could be as severe as tank 101-SY; however, this conclusion seems unreasonable because the naturally occurring GREs in the other tanks are much smaller than the GRES in tank 101-SY."

These models were developed for rollovers in tank 101-SY which involve much of the tank contents (i.e, whole tank rollovers). These result in crust drops which vary from 4.6 to 14.5 in. and incorporate $31 \%$ and $95 \%$ of the nonconvective layer, respectively (LANL 1994, Appendix AQ). These events usually show temperatures in the lower tank regions, at the instrument tree location, decreasing as mixing and cooling disrupts the nonconvective layer. However, there are also smaller events where the thermocouples in the nonconvective layer are not affected by the GRE. These disruptions are localized enough that their effect is not measured by the thermocouples because the event is too far away. This seems to be typical for double-she11 flammable gas watch list tanks other than tank 101-SY. The consistently smaller crust drops, 1 to 4 in., and frequent lack of temperature change in the lower tree thermocouples during these events indicate that whole tank rollovers do not apply for these tanks. The GRE appears to sporadically occur at various regions around the tank bottom. The depth of the nonconvective region may be a factor here. Tank 101-SY appears to have a nonconvective region 200 to 250 in. deep while the other tanks appear to be about 150 in. or less as shown in Table 3-3. 
The approach used here to establish the maximum size of gas release is to examine the tank surface level histories for the last several years, select the maximum 24-hour level changes, and calculate the quantity of gas that must have been released. As will be described later, there is ample conservatism remaining in this approach because burning events need only use the maximum inventory of gas which is available to burn at any time during the release history. The instantaneous release assumes it is all available and is very conservative.

Measurements from tank 101-SY are used to confirm that abrupt crust drops provide a conservative estimate of the quantity of slurry gas existing in the dome space. Figure 4-1 shows the hydrogen gas concentrations in the tank dome plotted vs crust drop. The circles show measured values and the solid line represents an average concentration if the crust drop were an instantaneous release with complete mixing with the dome air. Note the solid line far exceeds the data because slurry gas is lost by self-purging (i.e., volume of dome gas pushed out by incoming slurry gas will also contain some slurry gas) during the release process and also removed by ventilation flow. It should be remembered the ventilation flow rate for 101-SY is high and dome volume is small. Both of these factors increase the difference between the solid line and the data. However, this demonstrates that using prompt crust drops to calculate gas release overpredicts the dome gas concentrations.

There is another item of importance which can be seen from Figure 4-1 where FATHOMS (Burke 1990) code predictions are also included. These incorporate the ventilation flow rate, a gas release rate, and the dome volume effects using an instantaneous mixing model. The agreement with hydrogen concentration measurements is quite good. So, in addition to confirming the FATHOMS modeling, this implies that slurry gas mixing with the air is very rapid. Even though gas samples were taken as $10 \mathrm{w}$ as $18 \mathrm{in}$. above the waste surface, high concentrations of slurry gas were not measured. It is possible that gas sampling missed a plume of more concentrated gas, but the number of samples taken implies that if high concentration regions existed, at least some measurements would show this. Since this did not happen, we are led to the conclusion that a completely mixed assumption is more appropriate. As will be shown later, this leads to nonflammable events and no consequences for all expected gas releases for the tanks included in this report. While this may be the correct conclusion, in order to answer what-if type questions, we will proceed by postulating that a combustible plume might occasionally exist, assume ignition and combustion, and analyze the consequences. It will be shown that even this event does not exceed Hanford Site 1 imits as given in WHC-CM-4-46 (WHC 1993).

\subsection{GAS RELEASE QUANTITIES}

As described previously, the amount of gas released into the dome space will be estimated from the surface level drops. The level is normally measured once a day so rigorous definition of the release rate during recent years is not possible. In some cases, it is observed that the level change occurs over several days and so the release is believed to be slow and spread over a considerable time period. The slower the rate of gas release to the dome, the more time is available to mix and purge some slurry gas, which reduces the peak concentration levels attained. However, this assessment 
WHC-SD-WM-SAR-064, Rev. 0

Figure 4-1. Gas Mixing Indications in Tank 101-SY.

Peak Hydrogen Quantities for Tank 101-SY

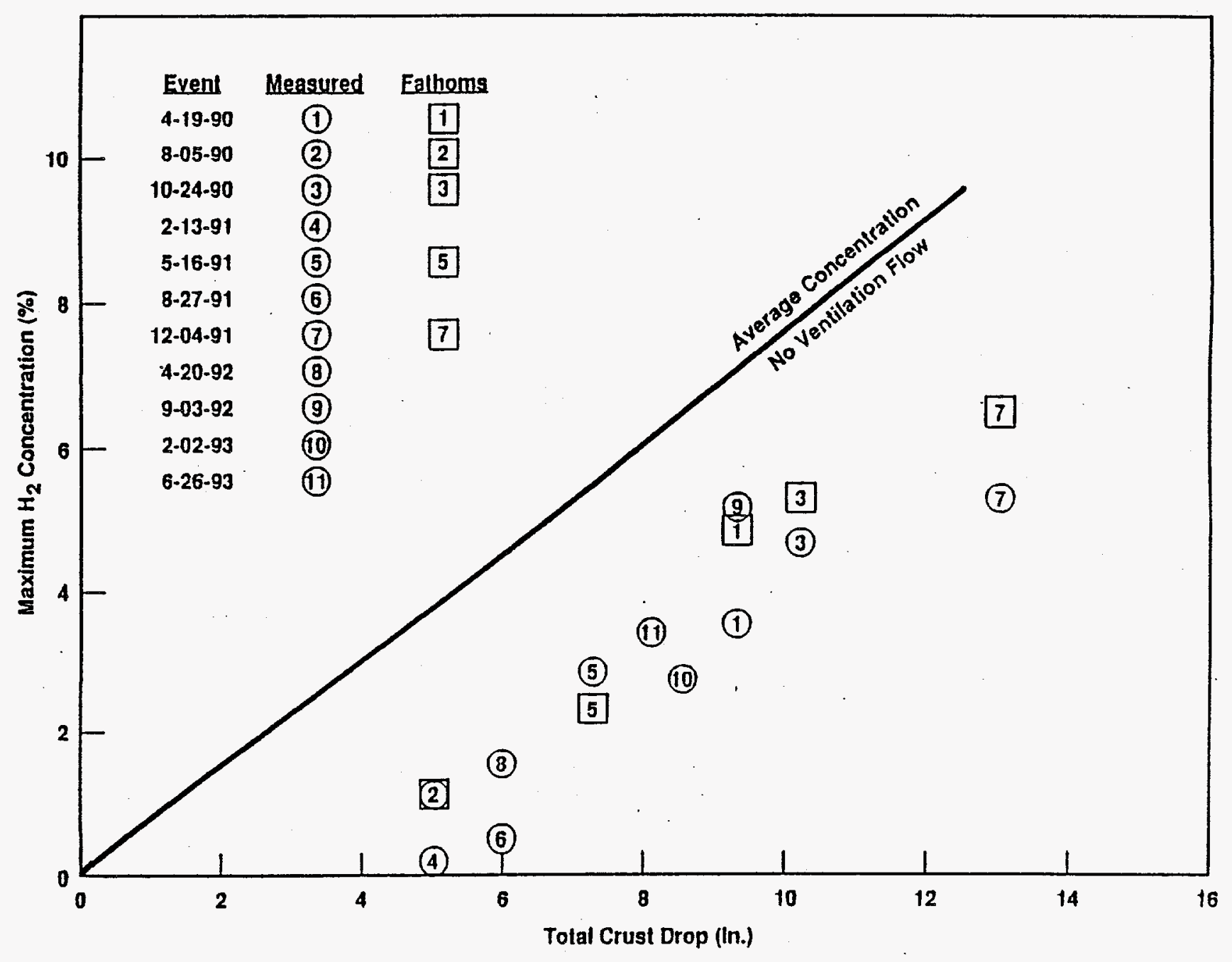

H9309037. 1 
assumes the largest 24-hour level change occurs instantaneously and releases all of this gas into the dome. These level changes have been documented by previous studies (Reynolds 1994; Wilkins 1994) and are shown in Table 4-1.

Table 4-1. Dry Gas Release Quantities.

\begin{tabular}{|c|c|c|c|}
\hline Tank ID & $\begin{array}{c}\text { Level drop, } \\
\text { in. }(\mathrm{cm})\end{array}$ & $\begin{array}{c}\text { Release, } \\
\mathrm{ft}^{3} / \mathrm{in.}\left(\mathrm{m}^{3} / \mathrm{cm}\right)\end{array}$ & $\begin{array}{c}\text { Release, } \\
\mathrm{ft}^{3}\left(\mathrm{~m}^{3}\right)\end{array}$ \\
\hline $101-\mathrm{AW}$ & $1.6(4.06)$ & $854(9.52)$ & $1,366(38.7)$ \\
\hline $103-\mathrm{AN}$ & $2.5(6.35)$ & $773(8.62)$ & $1,933(54.7)$ \\
\hline $104-\mathrm{AN}$ & $3.6(9.14)$ & $791(8.82)$ & $2,848(80.6)$ \\
\hline $105-\mathrm{AN}$ & $2.3(5.84)$ & $823(9.18)$ & $1,893(53.6)$ \\
\hline $103-\mathrm{SY}$ & $1.7(4.32)$ & $782(8.72)$ & $1,330(37.7)$ \\
\hline
\end{tabular}

It should be emphasized the quantities of gas shown in Table 4-1 do not represent all the slurry gas stored in the waste. Even following a GRE, there is probably still a substantial amount of gas left within the nonconvective layer. But experience with the mixing pump in tank 101-SY has shown the gas is not easily released. Substantial agitation by the mixing pump produced an increased rate but did not trigger sudden precipitous releases. Figure 4-2 shows surface level data from two full-scale tests (\#4 and \#5) for 101-5Y. The mixing pump was run for 1 hour at $750 \mathrm{rpm}$ at different directions of flow discharge. The surface level, as measured by both the FIC (Food Instrument Corporation) and the Manual Tape, does not show an abrupt drop. There is no evidence that the remaining gas in the nonconvective layer is easily released.

Studies of gas bubble retention by McDuffie (1994) indicate the bubbles are held by several mechanisms (e.g., viscous trapping of bubbles, stabilization in three-phase foams at hydrophobic surfaces, capillary channel gas accumulation, mechanical trapping in crystal clusters, and tight engulfment in "armored bubbles"). The major release process is triggered when an unstable clump of nonconvective waste rises to the top of the tank, reducing hydrostatic pressure so the bubbles grow in size and disrupt the matrix.

It should be noted the Table 4-1 results do not include the condensible gas components added by the convective region during the GRE such as the water vapor and ammonia. Corrections for these components will be included in the next section after the gas composition has been established. 

WHC-SD-WM-SAR-064, Rev. 0

\subsection{GAS COMPOSITION}

The gas composition is based on results from tank 101-SY, which has the most complete characterization to date. A good description of the history of the slurry gas measurements is found in Appendix C of LANL (1994). The measurements give the composition for only the noncondensible portion of the release gas. The condensibles such as water vapor and ammonia appear to be lost during sample preparation and the indicated gas fractions must be corrected for this. This was done in LANL (1994) and their best estimate composition is chosen for this assessment. In addition, a conservative estimate composition is selected which reflects maximum fuel quantities expected and provides a bounding value for the combustion energy. The Los Alamos National Laboratory (LANL) conservative estimate is based on a maximum waste temperature of $125^{\circ} \mathrm{F}$. This temperature exceeds waste temperatures in the study group of tanks, higher temperatures increase the release of ammonia as discussed below. We have rounded the concentration values somewhat for our analysis, and the combustion energy slightly exceeds the LANL values. These gas compositions are shown in Table 4-2.

Table 4-2. Best Estimate and Conservative Estimate for Release Gas Compositions.

\begin{tabular}{|l|c|c|c|}
\hline \multicolumn{1}{|c|}{ Parameter } & $\begin{array}{c}\text { LANL best estimate } \\
(\%)\end{array}$ & $\begin{array}{c}\text { LANL conservative } \\
(\%)\end{array}$ & $\begin{array}{c}\text { Conservative } \\
(\%)\end{array}$ \\
\hline Hydrogen & 28.77 & 28.45 & 30 \\
\hline Nitrous oxide & 24.45 & 24.18 & 30 \\
\hline Ammonia & 10.95 & 22.03 & 20 \\
\hline Methane & 0.35 & 0.48 & 1.0 \\
\hline Carbon monoxide & 0.25 & 0.50 & 0.5 \\
\hline Nitrogen & 32.83 & 21.25 & 18.5 \\
\hline Water vapor & 2.4 & 3.1 & 0 \\
\hline \hline $\begin{array}{l}\text { Combustion energy, } \\
\text { kJ/mole }\end{array}$ & 128 & 164 & 11.03 \\
\hline LFL, \% slurry gas & 12.49 & 11.5 & 31 \\
\hline $\begin{array}{l}\text { Water vapor in } \\
\text { combustion } \\
\text { products, }\end{array}$ & 23.2 & 31 & 1.024 \\
\hline $\begin{array}{l}\text { Combustion product } \\
\text { mole ratio }\end{array}$ & 1.002 & 1.016 & \\
\hline
\end{tabular}

The best estimate composition is intended to provide calculational results for expected gas compositions and also quantify safety margins when comparing with conservative estimate results. The conservative estimate 
results allow for potential variations in gas compositions between tanks and ensure the calculational bounds and consequences of this report are not exceeded by subsequent GREs.

The main difference between the conservative and best estimate gases is the increase in the quantity of ammonia and, to a lesser extent, nitrous oxide. The addition of more fuel and oxidizer increases the combustion energy by $33 \%$. This substantially raises the product gas temperature and, because radiation heat transfer is dominant and is proportional to the fourth power of temperature, this increases the rate of heat transfer from the gas plume to the crust. Also, ammonia combustion creates more water vapor products which also increases the heat transfer rate. So, this selection of a conservative mix provides a considerable margin over compositions which have been measured in the tanks. Note the conservative gas combustion energy essentially duplicates the LANL conservative value and is about $35 \%$ greater than the LANL best estimate.

The last item in Table 4-2 is the ratio of product moles to initial moles of combustible gas. This is important for calculating the resulting pressure from a combustion event. Some reactions increase the molar quantity while others decrease it. However, the resultant value for the mix appears to stay close to 1.0. (Note that both the water vapor content and product ratio values shown in Table 4-2 use slurry gas mixed with an equal volume of air.)

\subsection{TOTAL GAS RELEASE QUANTITIES}

The condensible fraction sum for ammonia and water vapor in Table 4-2 is 0.1335 for the best estimate and 0.2 for the conservative case. Using the dry gas release as indicated by the crust drops, the actual gas release into the dome space may be calculated as shown in Table 4-3. The water vapor and ammonia releases are not indicated by the surface level change because they remain in the condensed phase until liberated at the free surface.

Table 4-3. Total Gas Release Quantities.

\begin{tabular}{|c|c|c|c|c|}
\hline \multirow{2}{*}{ Tank ID } & $\begin{array}{c}\text { Dome volume } \\
\left(\mathrm{ft}^{3}\right)\end{array}$ & $\begin{array}{c}\text { Dry gas release } \\
\left(\mathrm{ft}^{3}\right)\end{array}$ & \multicolumn{2}{|c|}{ Actual gas release $\left(\mathrm{ft}^{3}\right)$} \\
\cline { 4 - 5 } & 37,634 & 1,366 & 1,576 & 1,708 \\
\hline $101-\mathrm{AW}$ & 61,100 & 1,933 & 2,231 & 2,416 \\
\hline $101-\mathrm{AN}$ & 46,010 & 2,848 & 3,287 & 3,560 \\
\hline $104-\mathrm{AN}$ & 37,360 & 1,893 & 2,185 & 2,366 \\
\hline $105-\mathrm{AN}$ & 1,330 & 1,535 & 1,663 \\
\hline $103-\mathrm{SY}$ & 87,609 & 1,30 estimate & Conservative gas \\
\hline
\end{tabular}


An additional conservative case is selected which bounds all of the tanks and will be used for developing a radioactive source term. This uses a conservative gas mixture, $35,000 \mathrm{ft}^{3}$ dome volume, and 4,000 $\mathrm{ft}^{3}$ of siurry gas. The gas composition and quantity exceed observations for all the tanks being assessed and the small dome volume maximizes the heat to the crust and, as a result, maximizes radioactive release calculations.

\subsection{COMPLETE MIXING RESULTS}

The slurry gas fraction in the dome space can be calculated from the values in Table 4-3. Using tank 101-AW as an example, dividing the conservative gas release by the dome volume produces a mixture fraction of 4.54\%. This compares with the LFL shown in Table $4-2$ as $11.03 \%$. So, even with conservative assumptions about gas quantities, if the slurry gas becomes well mixed, it is no longer combustible.

Similar results may be obtained for the other tanks. Figure 4-3 shows that all mixtures are much less than the LFL, most by less than a factor of one-half. (The stacked bar in Figure 4-3 is used to indicate the components of the slurry gas and to emphasize the fuel portion is only about one-half.) These results demonstrate the only way a gas combustion event could occur in these tanks is during some short interval before mixing is completed. The consequences of this event will be analyzed as a plume burn. 
WHC-SD-WM-SAR-064, Rev. 0

Figure 4-3. Completely Mixed Slurry Gas Concentrations (Conservative Gas Mix).

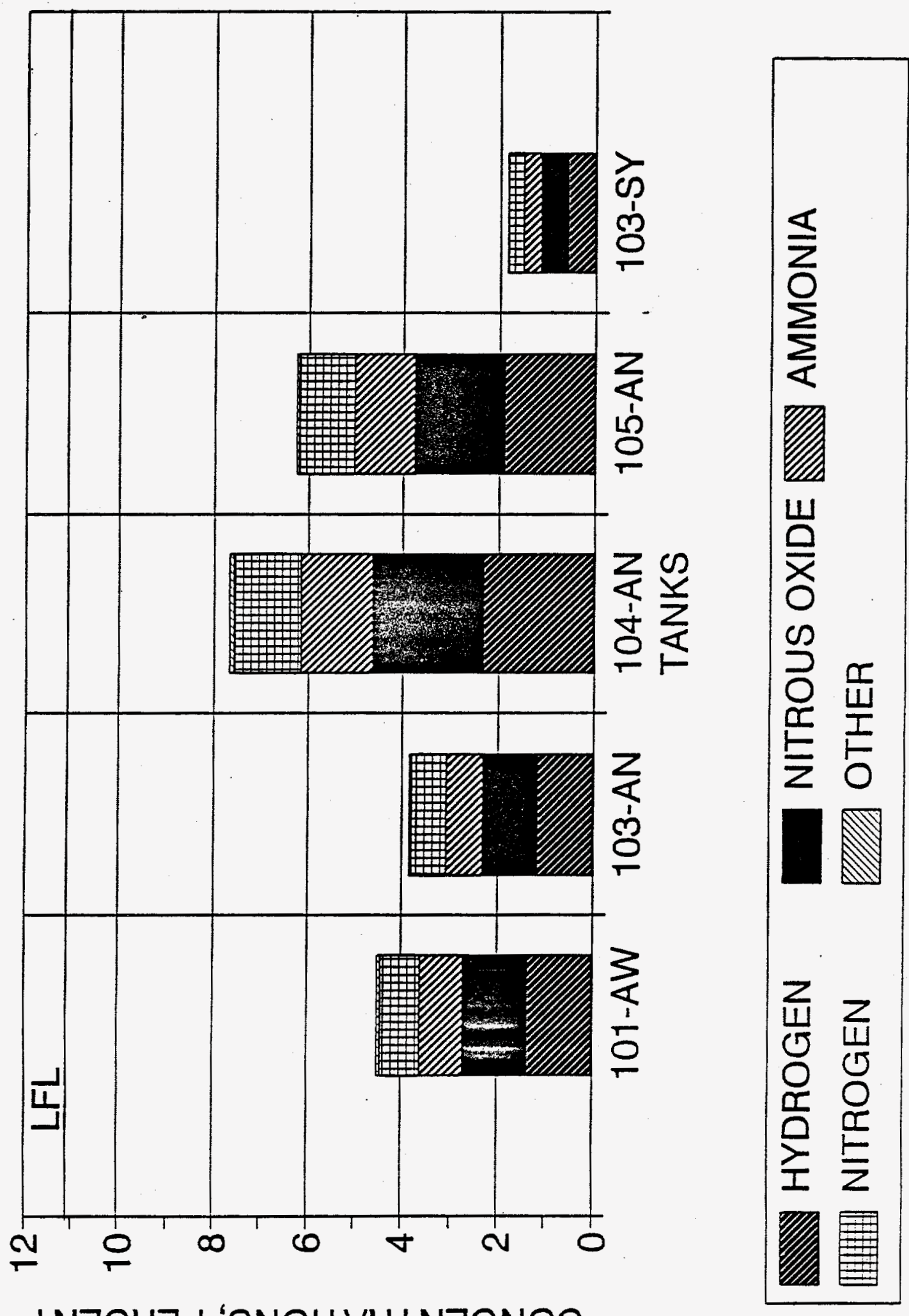

$\perp N \exists O Y \exists d$ 'SNOI $\forall Y \perp N \exists O N O O$ 
WHC-SD-WM-SAR-064, Rev. 0

This page intentionally left blank. 


\subsection{GAS MIXING STUDIES}

A computer simulation of slurry gas release into the tank dome was used to evaluate the length of time flammable concentrations could exist in the dome space and the total accumulated amount of gas. The sensitivity of the results to changes in release duration and release area was examined parametrically. Spatial concentration distribution was also parametrically determined.

\subsection{DEFINITION OF CONDITIONS}

During episodic GREs, a concentrated mixture of fuel gases and oxidizing gas is released into the air space in the tanks. In the tank, fuel mixes with air and is exhausted from the tank by the tank farm ventilation system. In this report, the length of time a flammable mixture exists at any location in the tank is considered the time at risk. The contact of a spark or ignition source with the gas mixture in the tank would result in a fire. At all other times, an ignition source would be harmless. In order to determine the time at risk, the mixing of slurry gas and air in the tanks' free volume has been investigated using the GOTHIC code (Wood 1994). The GOTHIC results are also used to investigate fuel gas concentration spatial distributions, since concentrations only slightly above the LFL produce low burn pressure.

The GOTHIC code is an updated version of the FATHOMS code (Burke 1990). The FATHOMS computer code is a direct extension of the general thermalhydraulic analys is code, COBRA-NC, which was developed by Pacific Northwest Laboratory (PNL). FATHOMS encompasses essentially all of the COBRA-NC capabilities, but has been modified by Numerical Applications, Inc. to enhance the modeling for containment-type analyses. The code solves the conservation equations for mass, momentum, and energy for multicomponent two-phase flow. The code models the effects of the ventilation system on in-tank flow patterns, natural convection flow in the tank, and effects of momentum and buoyancy of the low-density slurry gas release.

The variables affecting mixing behavior defined for this study are gas composition, tank ventilation rate, tank free volume, slurry gas input volume, gas release area, and gas release rate. The choice of each of these variables is discussed below.

For the mixing calculations, where molar density would show up as a buoyancy effect, the following gas composition was selected: $30 \% \mathrm{H}_{2}, 20 \% \mathrm{NH}_{3}$, $30 \% \mathrm{~N}_{2} \mathrm{O}, 20 \% \mathrm{~N}_{2}$. This mixture has a molar density of 22.8 , which is close to that of the conservative mixture of 22.68 as shown in Section 4.0 .

A ventilation rate of $1,000 \mathrm{ft}^{3} / \mathrm{min}$ for the six AW tanks is given in the Interim Safety Basis (ISB) (Leach and Stahl 1993) Systems Description; $800 \mathrm{ft}^{3} / \mathrm{min}$ is given for the seven AN tanks. The systems are operated so that each tank will have essentially the same amount of air flow. The mixing 
calculations are not greatly affected by ventilation rate in this range, and $100 \mathrm{ft}^{3} / \mathrm{min}$ was adopted as an average minimum value. The operating specifications for watch list tanks (WHC 1992) do not mandate minimum ventilation requirements in these tanks.

The tank free volume is shown in Table 5-1. For the mixing studies, three nominal free volumes were considered: $35,000,45,000$, and $85,000 \mathrm{ft}^{3}$. However, in setting up the GOTHIC mixing model with suitable node sizes (Wood 1994), the actual volumes ended up as $38,828,47,668$, and $83,117 \mathrm{ft}^{3}$, respectively, for the three study cases. In thijs report, these three volumes are identified as $38,800,47,700$, and $83,100 \mathrm{ft}^{3}$, respectively.

Table 5-1. Tank Free Volume.

\begin{tabular}{|c|c|c|}
\hline Tank & Free volume $\left(\mathrm{ft}^{3}\right)$ & Reference \\
\hline $101-\mathrm{AW}$ & 37,634 & Wilkins (1994) \\
\hline $103-\mathrm{AN}$ & 61,100 & 'Reynolds (1994) \\
\hline $104-\mathrm{AN}$ & 46,010 & Reynolds (1994) \\
\hline $105-\mathrm{AN}$ & 37,360 & Reynolds (1994) \\
\hline $103-\mathrm{SY}$ & 87,600 & Fox et a1. (1993) \\
\hline
\end{tabular}

Gas release based on the largest daily surface level drop recorded (Reynolds 1993) is shown in Table 5-2. The maximum drop observed in this group of tanks has been rounded up to $4 \mathrm{in.}$, and release per inch drop has been rounded up to $900 \mathrm{ft}^{3}$. Thus, slurry gas input for mixing studies is taken as $3,600 \mathrm{ft}^{3}$ at tank temperature and $1 \mathrm{~atm}$.

Table 5-2. Maximum Gas Release.

\begin{tabular}{|c|c|c|c|}
\hline Tank & $\begin{array}{c}\text { Maximum drop } \\
\text { (in.) }\end{array}$ & $\begin{array}{c}\text { Gas release } \\
\left(\mathrm{ft}^{3}\right)\end{array}$ & $\begin{array}{c}\mathrm{ft}^{3} \text { release per } \\
\text { in. drop }\end{array}$ \\
\hline $101-\mathrm{AW}$ & 1.6 & 1,366 & 854 \\
\hline $103-\mathrm{AN}$ & 2.5 & 1,933 & 773 \\
\hline $104-\mathrm{AN}$ & 3.6 & 2,848 & 791 \\
\hline $105-\mathrm{AN}$ & 2.3 & 1,893 & 823 \\
\hline
\end{tabular}

The LANL Safety Assessment (LANL 1994) postulates the slurry gas release in a tank 101-SY maximum burp to occur over one-half the waste surface area. The prompt release is what is important in mixing and burning studies, but only a 1-hour release is available for tank 101-AW and 1-day releases for the remaining tanks in this study. We have taken the releases in these tanks to 
be nominally one fifth to one third of the tank 101-sY releases; i.e., 2 in. versus $10 \mathrm{in.}$ or $4 \mathrm{in}$. versus $12 \mathrm{in.} \mathrm{of} \mathrm{waste} \mathrm{surface} \mathrm{level} \mathrm{drop.} \mathrm{Thus,} \mathrm{the}$ release area is calculated as:

$$
(1 / 3) \times(1 / 2) \times(4,400)=733 \mathrm{ft}^{2}
$$

For symmetry reasons, this area is approximated by the use of nine $100 \mathrm{ft}^{2}$ nodes, placed at the center of the tank, for the base case.

\subsection{GOTHIC CODE MODEL}

The node arrangement used for the base case is shown in Figures 5-1A and 5-1B. Slurry gas enters through the 9 nodes centered around node 25 at Level 1. Each of the central nodes is $100 \mathrm{ft}^{2}$, as stated earlier. The wall nodes are $10 \mathrm{ft}$ by $12.5 \mathrm{ft}$, such that total area is $4,000 \mathrm{ft}^{2}$. The ventilation air enters the top of the dome directly over node 25 and exits over node 39. Data plots of gas concentration versus time are provided in this report for the series of nodes beginning with nodes $25,18,11$, and 4 at the waste surface and extending to the top of the tank.

The distance above the waste surface for each node level is given in Table 5-3. For the base case, the highest levels available over nodes 11 and 4 are $11 \mathrm{ft}$ and $7.7 \mathrm{ft}$, respectively, owing to dome curvature.

Table 5-3. Node Spacing for Levels in Figures 5-1A and 5-1B.

\begin{tabular}{|c|c|c|c|}
\hline Leve1 & $\begin{array}{c}\text { Distance to } \\
\text { Surface } \\
(\mathrm{ft})\end{array}$ & Leve1 & $\begin{array}{c}\text { Distance to } \\
\text { Surface (ft) }\end{array}$ \\
\hline 1 & 0.2 & 9 & 4.4 \\
\hline 2 & 0.4 & 10 & 5.5 \\
\hline 3 & 0.6 & 11 & 6.6 \\
\hline 4 & 0.8 & 12 & 7.7 \\
\hline 5 & 1.0 & 13 & 8.8 \\
\hline 6 & 1.4 & 14 & 9.9 \\
\hline 7 & 2.2 & 15 & 11.0 \\
\hline 8 & 3.3 & 16 & 12.22 \\
\hline
\end{tabular}




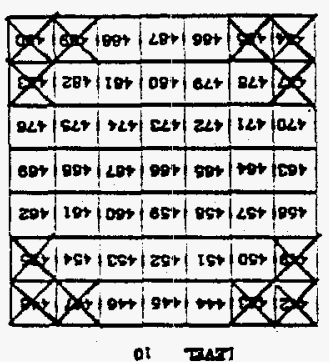

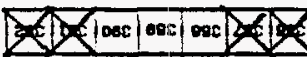

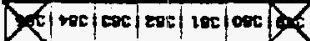

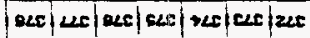

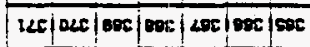

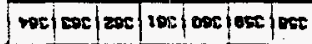

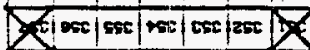
Exiercterseres

- man

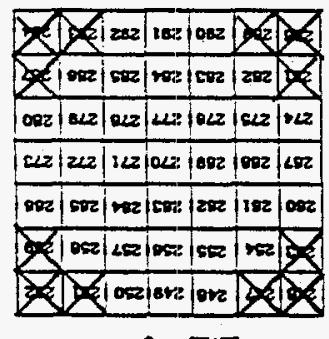

- now
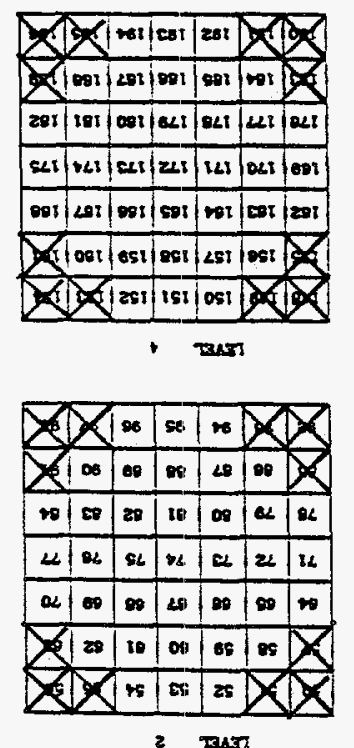

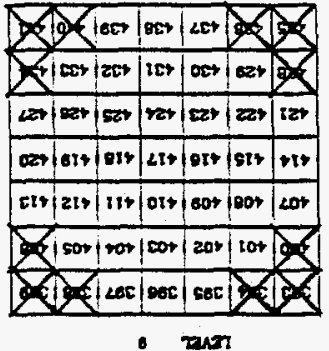

Q6irion (15x) -

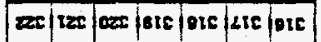

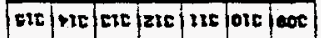

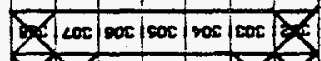

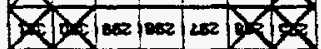

$2 \operatorname{man}$

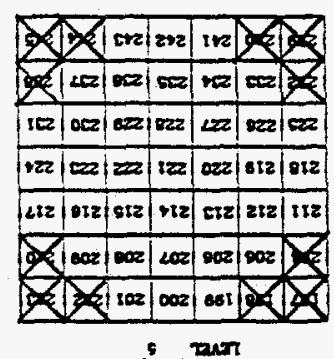

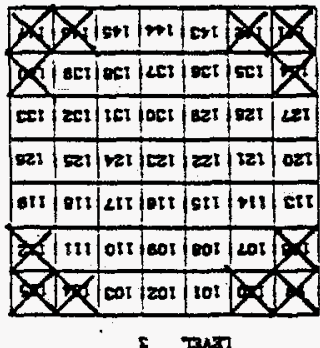

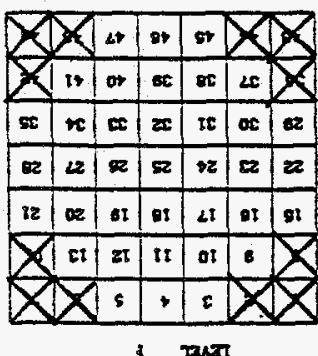

i zarr 
Figure 5-1B. GOTHIC Node Arrangement for Mixing Studies (Wood 1994).

I5VE⿱ 11

\begin{tabular}{|c|c|c|c|c|c|}
\hline xise & 403 & $\mid 404$ & 485 & 9 & \\
\hline (20198 & 500 & 502 & $502 \mid$ & 503 & \\
\hline $505 / 506$ & 300 & 508 & 508 & 510 & 11 \\
\hline $512 / 513$ & $\mid 514$ & $\mid 515$ & 510 & 517 & . \\
\hline $319 \mid 320$ & 321 & 1522 & $|322|$ & 524 & \\
\hline 301527 & 528 & 529 & 530 & 93 & \\
\hline$=01>0$ & 335 ! & 1538 & & & \\
\hline
\end{tabular}

Lera t3

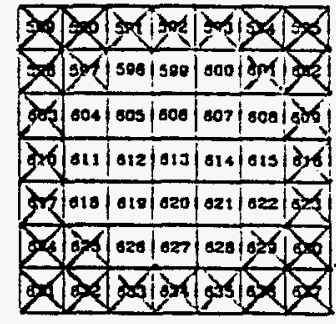

Love :5

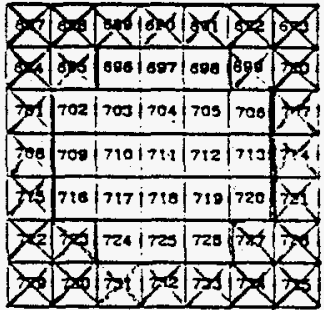

Lrver 12

\begin{tabular}{|c|c|c|c|c|c|}
\hline 30 & 500 & 540 & 530 & (5st) & $5 s 2$ \\
\hline$|354|$ & |353 & s5o & 557 & 558 & $|550|$ \\
\hline $501 \mid$ & |502| & $|583|$ & 504 & ses & $|500|$ \\
\hline 568$\}$ & 560 & $570 \mid$ & 571 & $|572|$ & $|573|$ \\
\hline & 789 & $|57|$ & 578 & 579 & 1580 \\
\hline & & & & & \\
\hline
\end{tabular}

Lerer 14

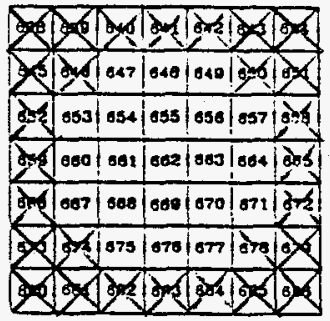

(Iver is

(1)

(1)

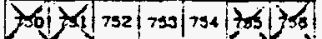

(7)

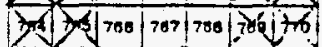

(4)

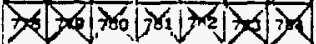




\subsection{TIME AT RISK}

Time at risk is estimated using Figures 5-2 through 5-12 for the base case. The base case used $3,600 \mathrm{ft}^{3}$ of flammable gas entering over an area of $900 \mathrm{ft}^{2}$ in the center of the tank. The only variable in the data set was time of gas injection, which was varied from 5 minutes to 100 minutes. The time at risk was measured from the time that any node in the tank reached $4 \%$ flammable fuel gas until the last node (always at a different location) dropped back to $4 \%$. No consideration was given to the fact that, in most cases, only a small amount of flammable gas is available when an inlet node reaches $4 \%$. At that time, only about $6 \mathrm{ft}^{3}$ of fuel gas would be present in the node volume of $150 \mathrm{ft}^{3}$, for the base case.

Time at risk and mixing behavior is illustrated in Figures 5-2 and 5-3 for the 5-minute gas input case. Figure 5-2 shows the center inlet node (25) rising to $13 \%$ at essentially time zero. The remaining four nodes on the plot directly above node 25 (i.e., nodes $74,123,172$, and 221) have successively lower concentrations that abruptly fall off when the gas injection is terminated at 300 seconds (the origin on the plots is at 500 seconds for Figures 5-2 through 5-9). Figure 5-3 shows the last nodes to drop back to $4 \%$. These nodes are located at the top of the tank, above the inlet node that is next to the tank center. This set of nodes peaks about 3.5 minutes after the inflow starts, and then about an additional 27 minutes are required for the ventilation fan to purge out the gas in excess of $4 \%$. A similar mixing pattern is shown in Figures 5-4 and 5-5 for the 10-minute gas inlet case, except that peak concentrations are a little lower and the timing slightly perturbed. Another difference is that the last node to be purged out is one node closer to the tank wall.

For the 50-minute gas input case, Figure 5-6 shows the inlet node next to the center reaching $4 \%$ well ahead of the remaining four nodes in the set as a result of the greater mixing time afforded by the reduced gas injection rate. Figure 5-7 shows the same general pattern as the other injection times, but the peak is lower owing to more complete mixing and there is less spread in node gas concentrations. The top $6 \mathrm{ft}$ of the tank over node 18 (nodes 508-753) are essentially at a uniform concentration. The time at risk for this case starts at 9 minutes when the spike on Figure 5-6 crosses the $4 \%$ value and ends at 68 minutes when the last node on Figure 5-7 returns to $4 \%$.

The 100-minute injection case shows the same general behavior, delayed in time. This behavior is shown graphically in Figures 5-8 and 5-9. In this case, the influence of convective flow on the slow gas input rate shows up as more variability in the inlet node gas concentrations. The fuel gas concentration reaches $4 \%$ at 44 minutes, remains above $4 \%$ for about 2 minutes, retreats, and reaches above $4 \%$ at 57 minutes.

The base case in the gas mixing studies used a slurry gas input volume of $3,600 \mathrm{ft}^{3}$. This value was rounded up to $4,000 \mathrm{ft}^{3}$ for the conservative bounding crust burn and tank pressurization calculations. Therefore, the 50-minute case was repeated with a 4,000 $\mathrm{ft}^{3}$ gas input with all other variables left unchanged. The resuits are shown on Figures 5-10 and 5-11. The mixing pattern is nearly identical, but concentrations peak at higher 
WHC-SD-WM-SAR-064, Rev. 0

Figure 5-2. Gas Concentration vs. Time - 5 Minute Gas Input Time.

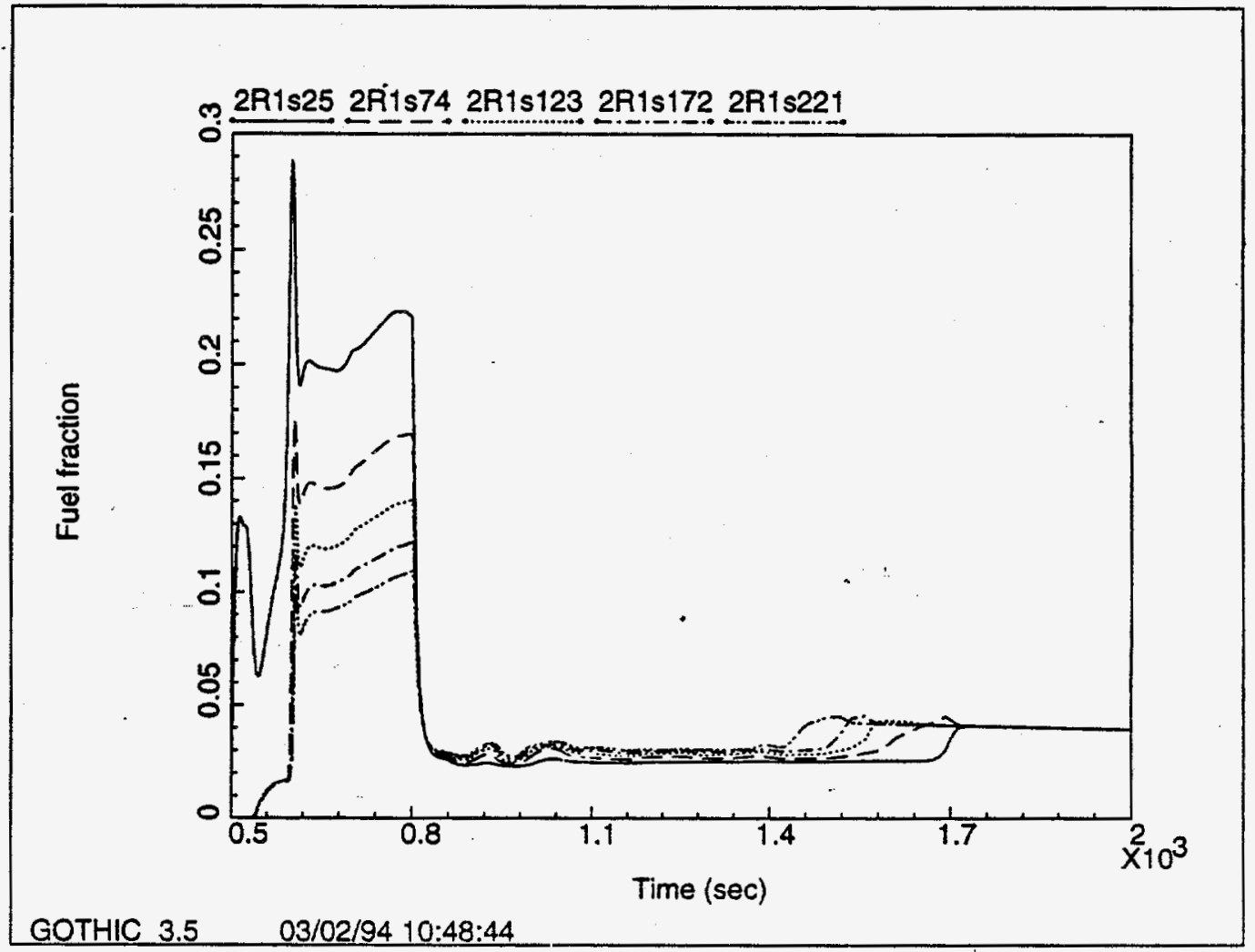

Figure 5-3. Gas Concentration vs. Time - 5 Minute Input Time.

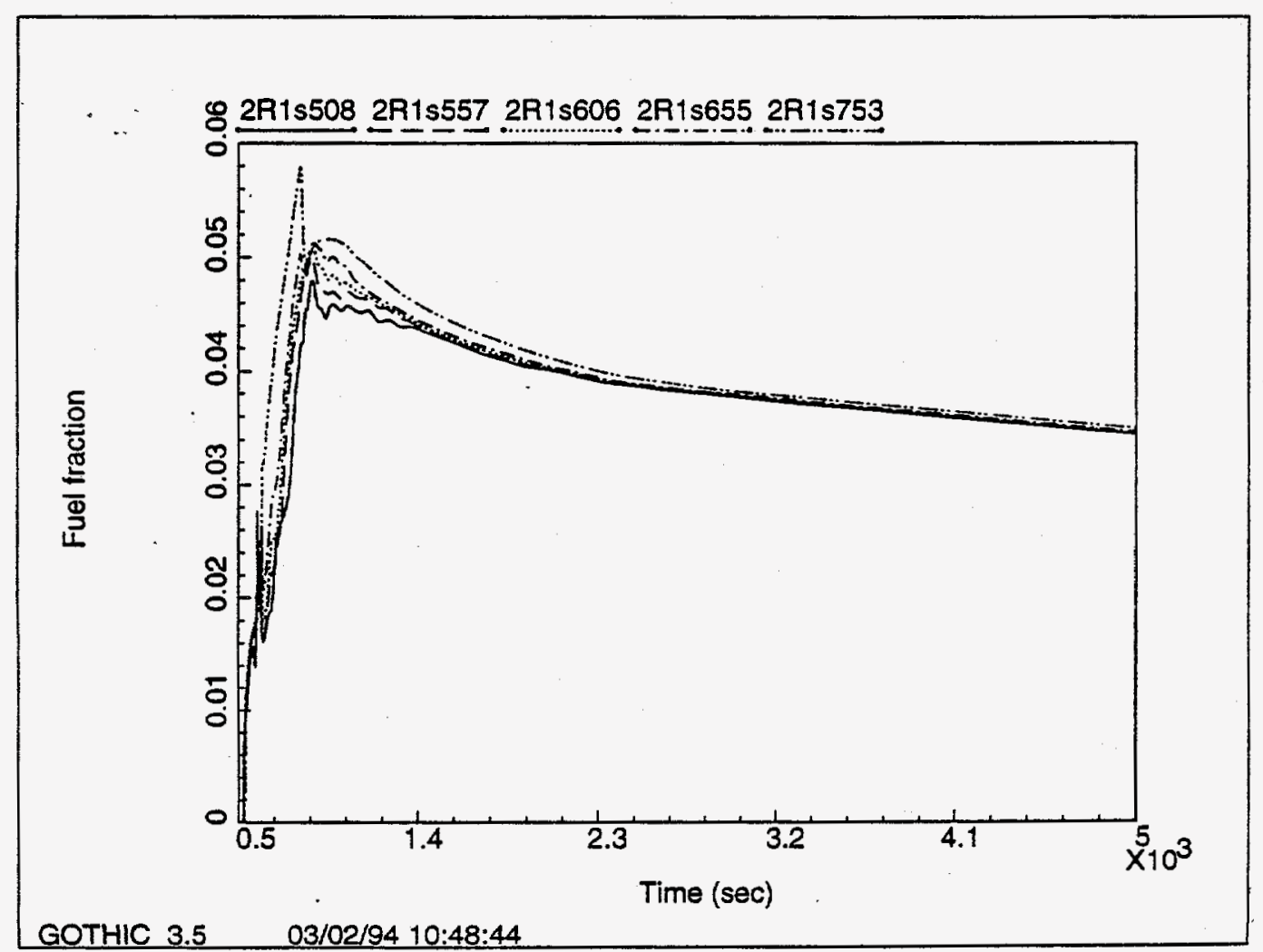


WHC-SD-WM-SAR-064, Rev. 0

Figure 5-4. Gas Concentration vs. Time - 10 Minute Gas Input Time.

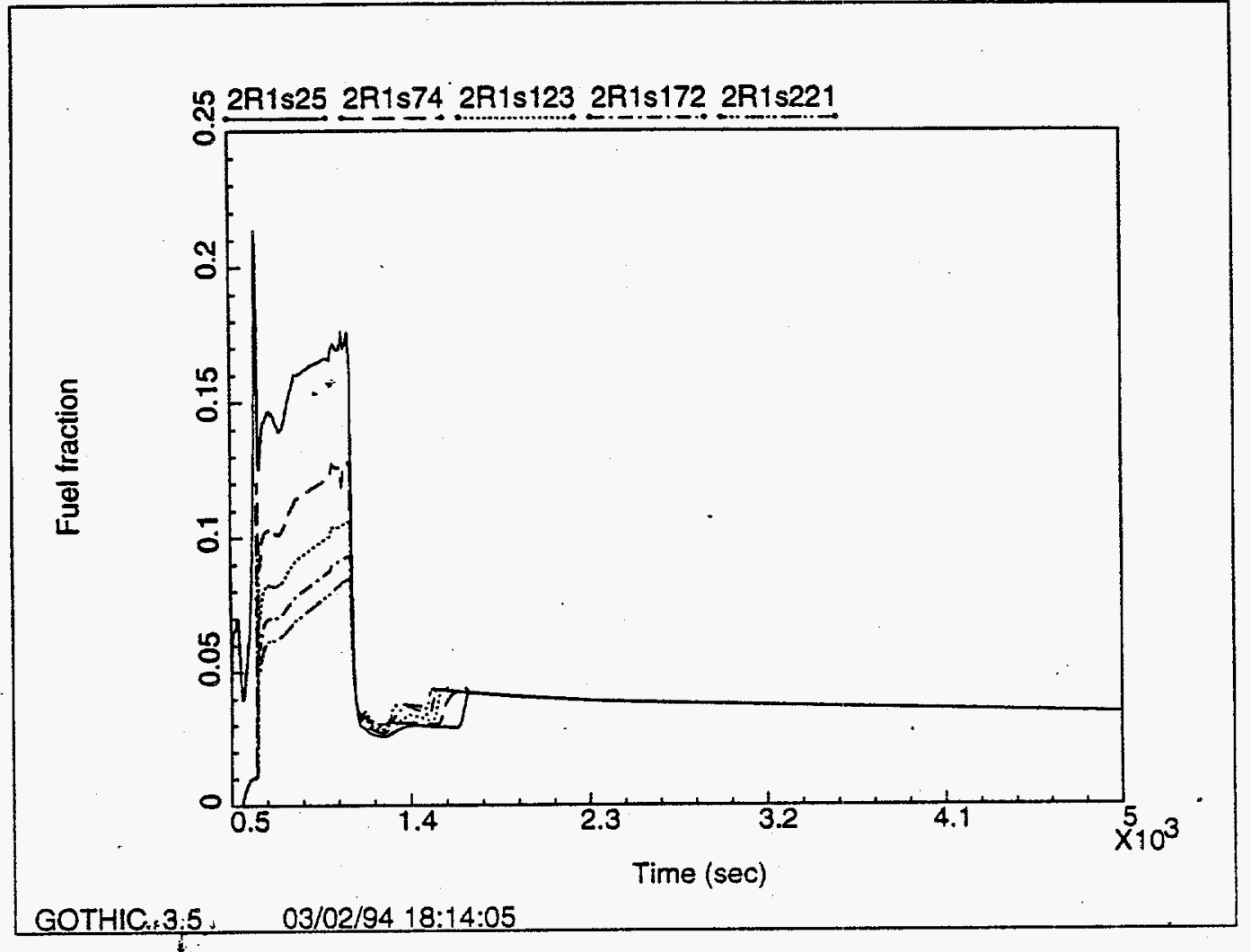

Figure 5-5. Gas Concentration vs. Time - 10 Minute Gas Input Time.

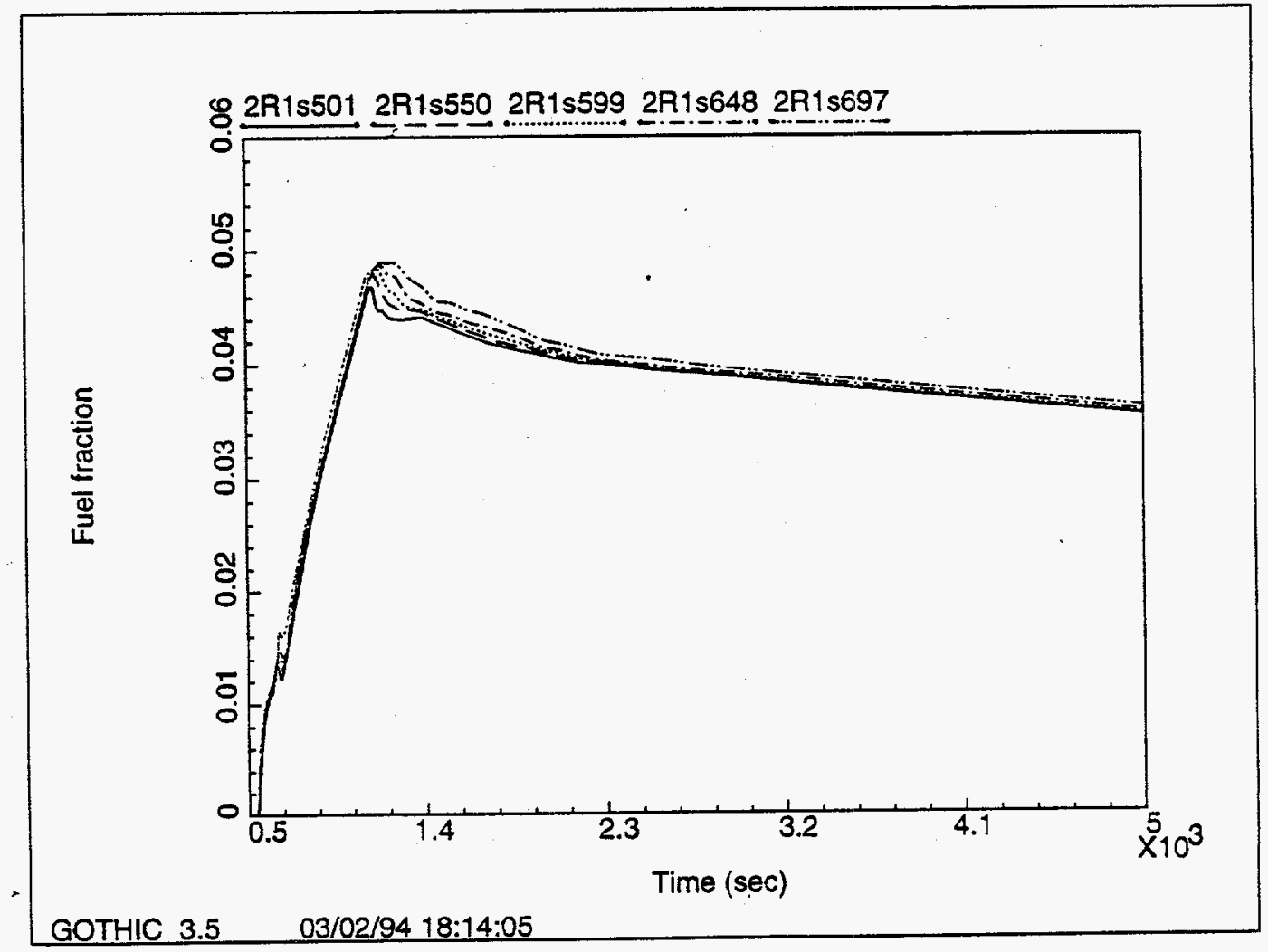


WHC-SD-WM-SAR-064, Rev. 0

Figure 5-6. Gas Concentration vs. Time - 50 Minute Gas Input Time.

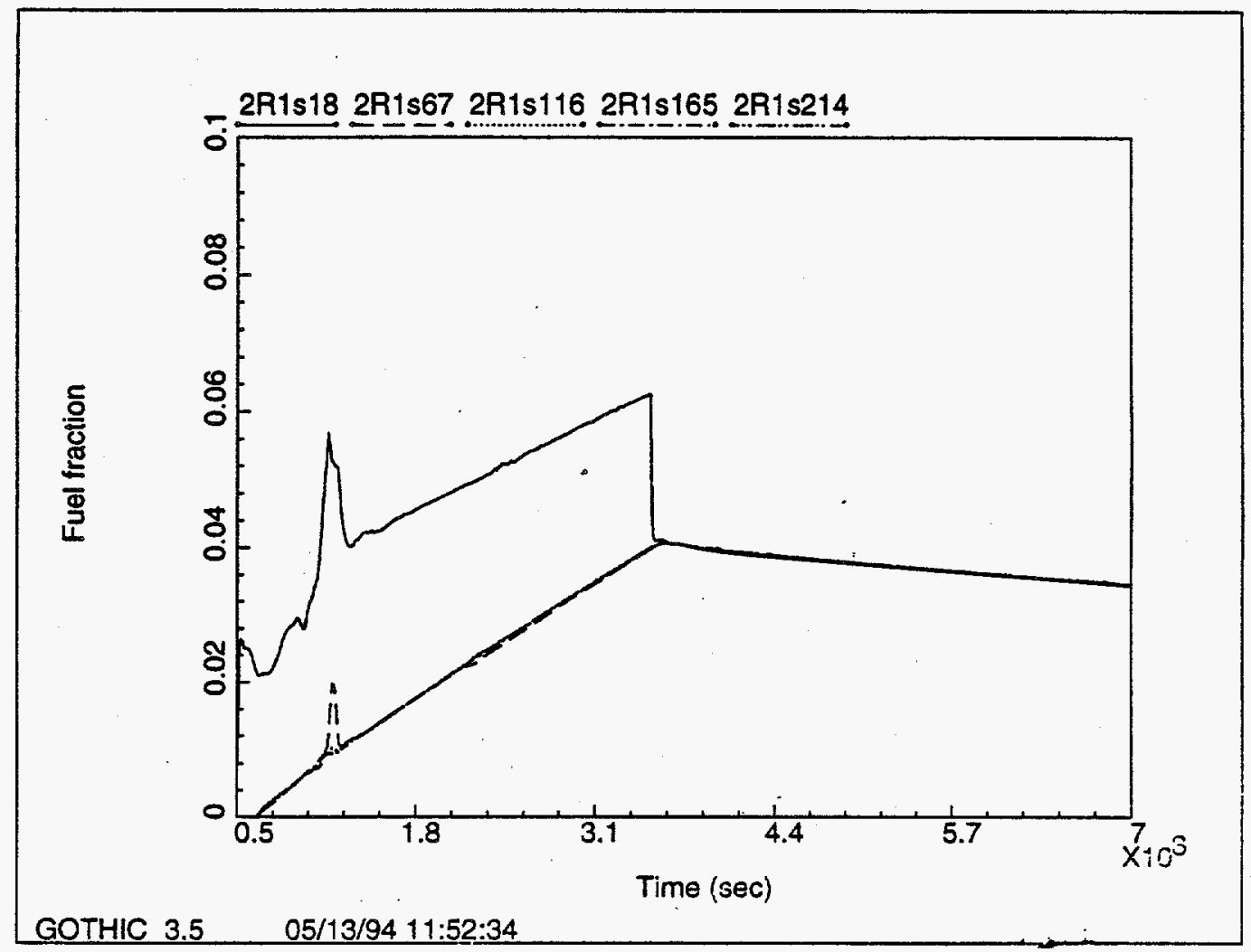

Figure 5-7. Gas Concentration vs. Time - 50 Minute Gas Input Time.

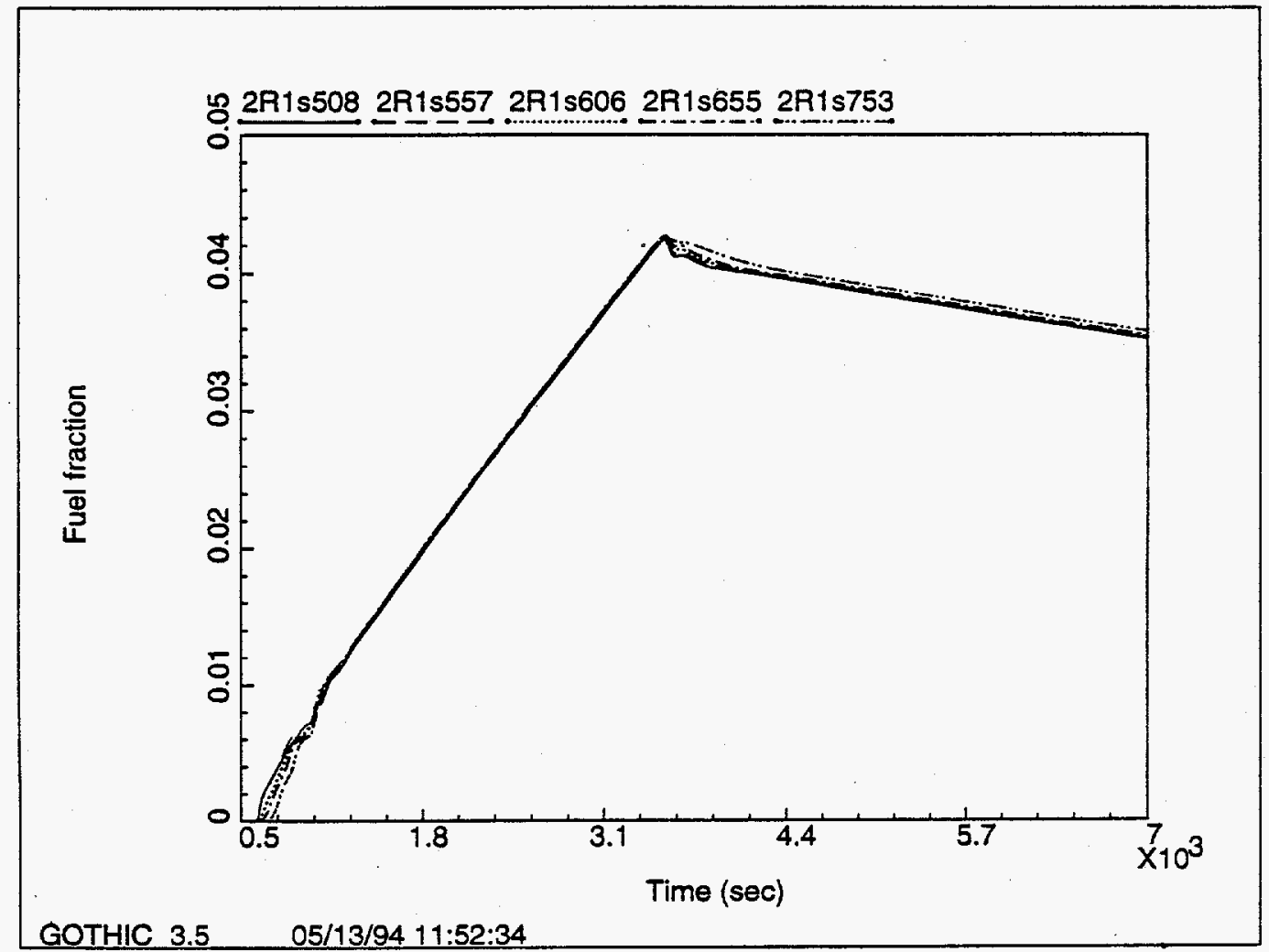


WHC-SD-WM-SAR-064, Rev. 0

Figure 5-8. Gas Concentration vs. Time - 100 Minute Gas Input Time.

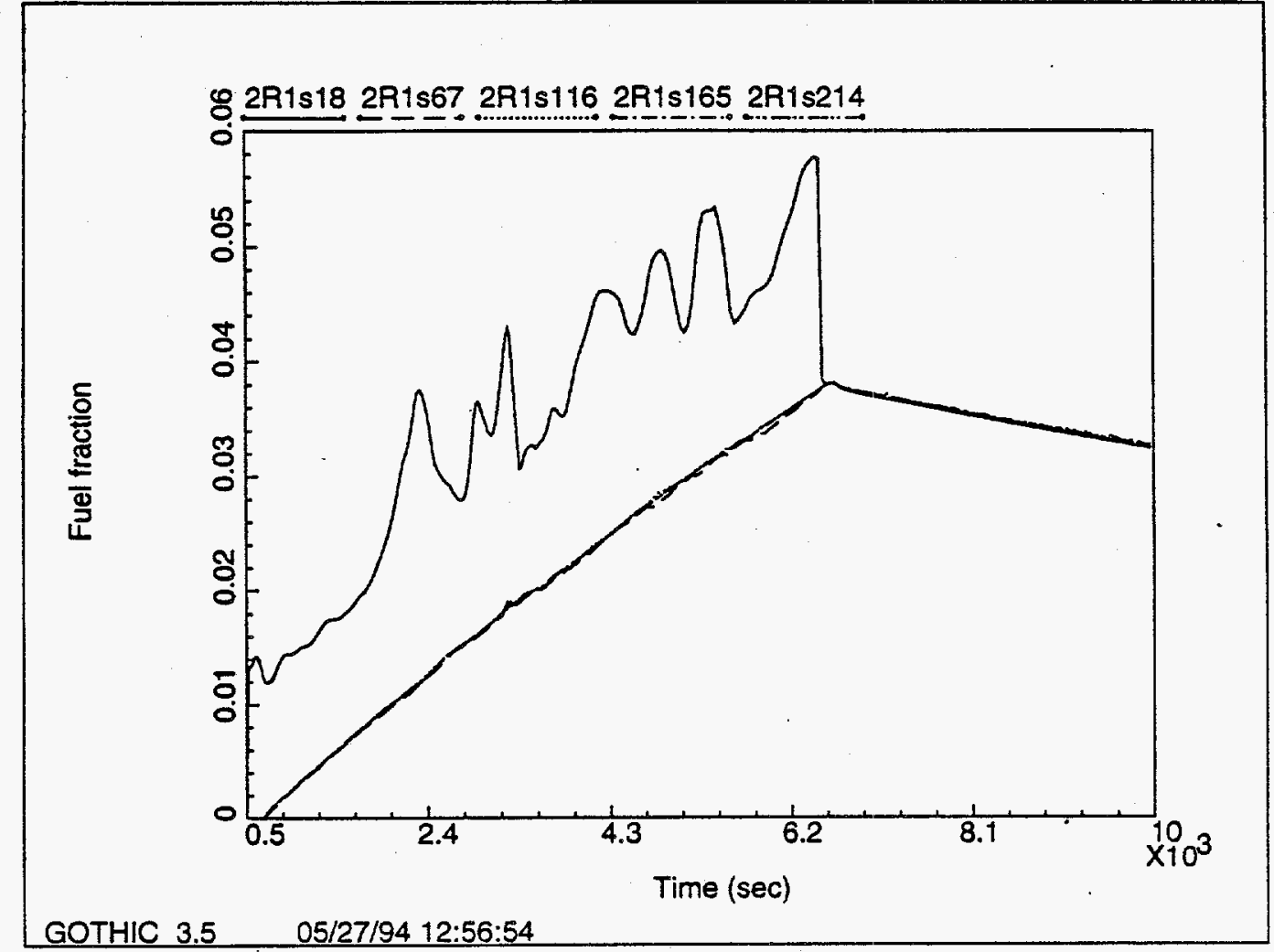

Figure 5-9. Gas Concentration vs. Time - 100 Minute Gas Input Time.

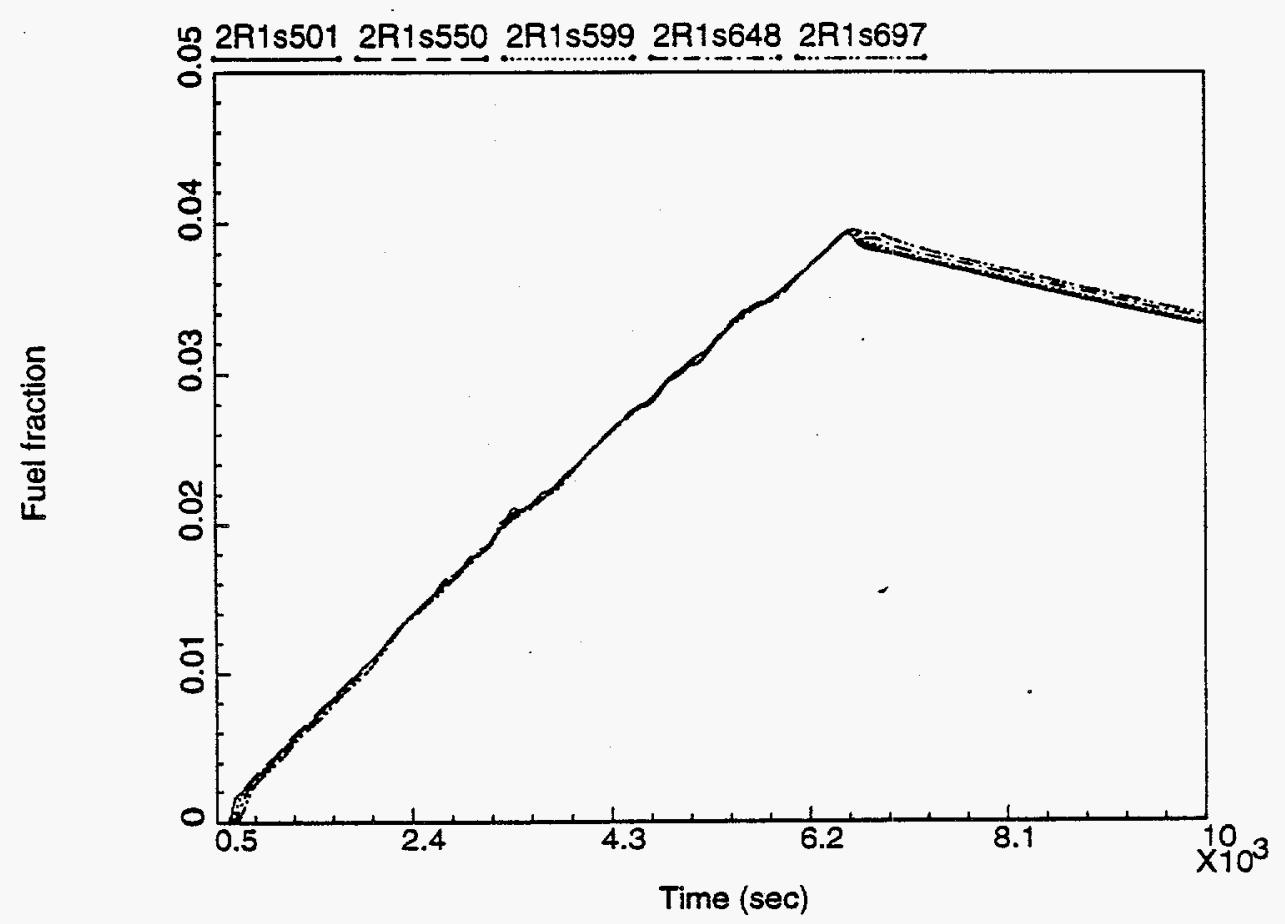

GOTHIC $3.5 \quad 05 / 27 / 9412: 56: 54$ 
WHC-SD-WM-SAR-064, Rev. 0

Figure 5-10. Gas Concentration vs. Time $-4,000 \mathrm{ft}^{3}$ STurry Gas Input, 50 Minute Input Time.

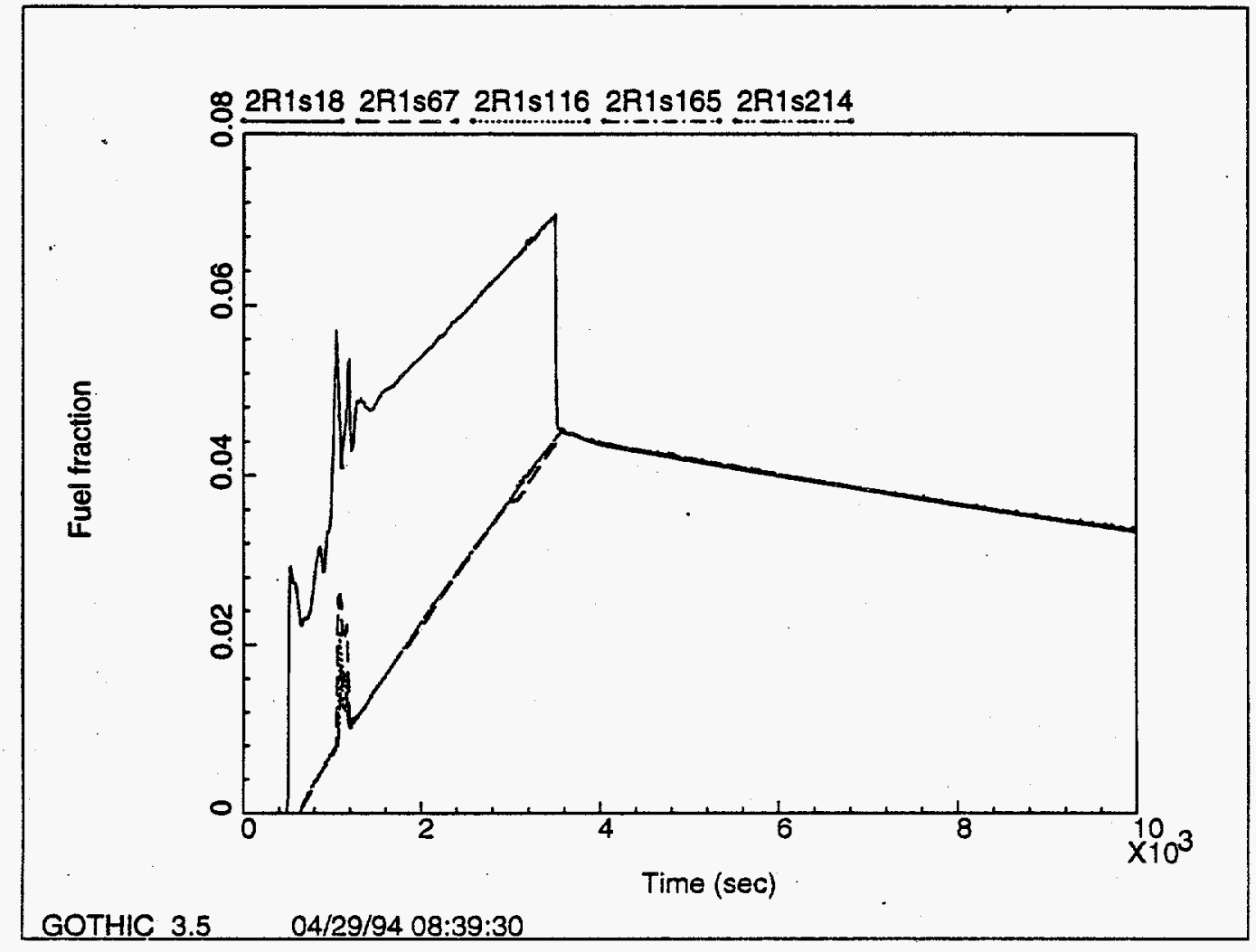

Figure 5-11. Gas Concentration vs. Time $-4,000 \mathrm{ft}^{3}$ Slurry Gas Input, 50 Minute Input Time.

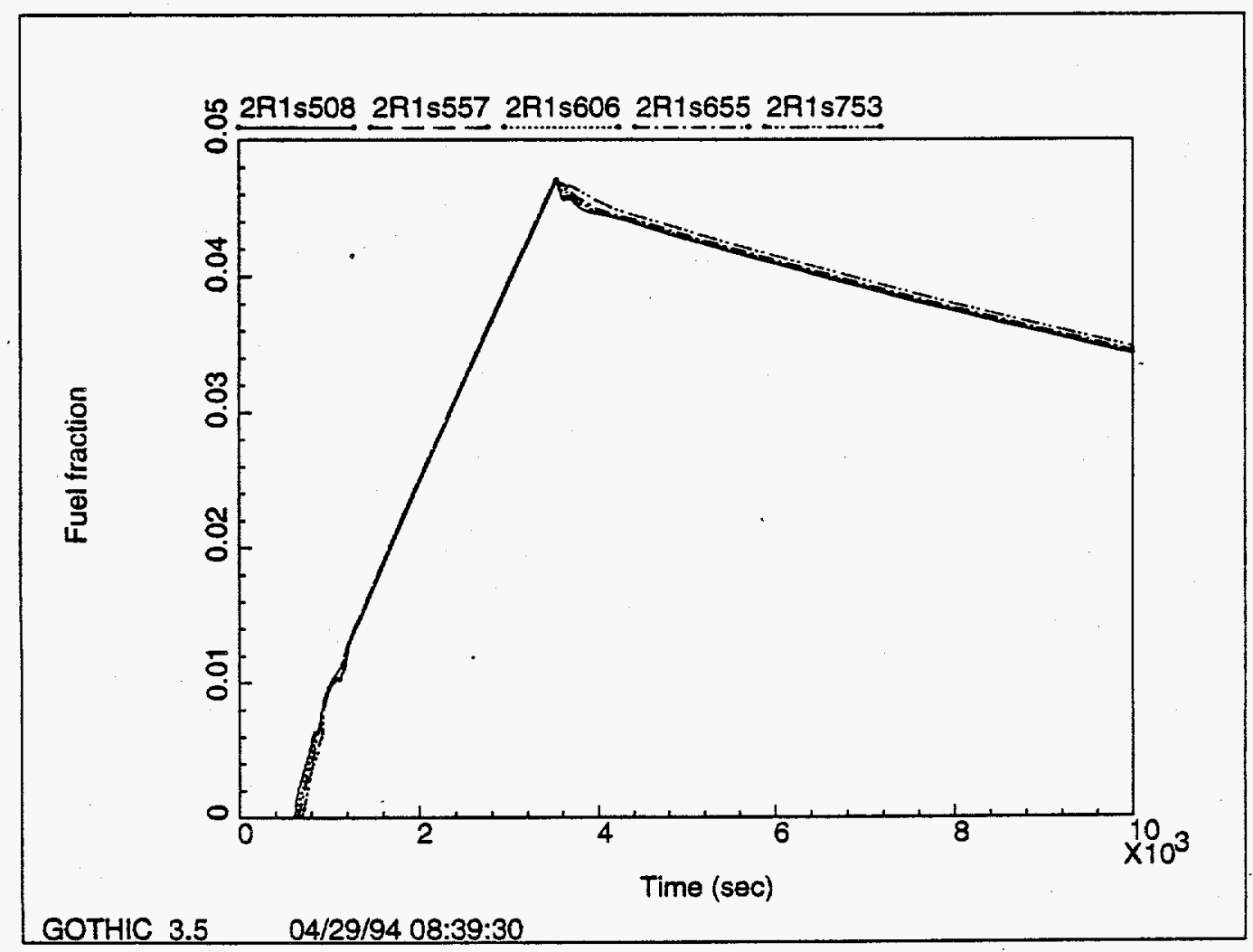


values, reflecting the larger volume of gas entering the dome. The increased concentration over $4 \%$ requires about 38 minutes more for the ventilation system to purge out the excess. This time increase is roughly proportional to the increase in the concentration above $4 \%$ for the two cases.

The total time that the dome concentration exceeds $4 \%$ of flammable gas for the foregoing cases is summarized in Table 5-4. It is seen that the longest time at risk is about 100 minutes. As discussed earlier, the time at

Table 5-4. Time at Risk - Base Cases.

\begin{tabular}{|c|c|c|c|c|c|}
\hline $\begin{array}{c}\text { Input } \\
\text { time } \\
(\mathrm{min})\end{array}$ & $\begin{array}{c}\text { Total slurry } \\
\text { gas input } \\
\left(\mathrm{ft}^{3}\right)\end{array}$ & $\begin{array}{c}\text { Max. conc. } \\
(\% \text { fuel })\end{array}$ & $\begin{array}{c}\text { Time to } \\
\text { reach } 4 \% \\
(\mathrm{~min})\end{array}$ & $\begin{array}{c}\text { Time to } \\
\text { return to } \\
4 \%(\mathrm{~min})\end{array}$ & $\begin{array}{c}\text { Total time } \\
>4 \%(\mathrm{~min})\end{array}$ \\
\hline 5 & 3,600 & 29 & 0 & 30 & 30 \\
\hline 10 & 3,600 & 21.5 & 0 & 40 & 40 \\
\hline 50 & 3,600 & 6.1 & 9 & 68 & 59 \\
\hline 50 & 4,000 & 7.1 & 8 & 105 & 97 \\
\hline 100 & 3,600 & 4.9 & 44 & 101 & 46 \\
\hline
\end{tabular}

risk definition considers the time any node concentration is at $4 \%$ or more and includes times when only a small volume of gas is at the LFL. The length of time that a significant volume of gas (a few hundred cubic feet of hydrogen) is present at flammable concentrations is less: approximately 34,20 , 10, and 58 minutes for the $10,50,100$, and 50 minute $-4,000 \mathrm{ft}^{3}$ cases, respectively.

All of these mixing results are based on $38,800 \mathrm{ft}^{3}$ free volume in the waste tank. This volume approximates that currently available in tanks 101-SY, 101-AW, and 105-AN. The effect of free volume on mixing and time at rjsk was investigated by repeating the mixing simulation at 47,700 and $83,100 \mathrm{ft}^{3}$ free volume, while holding all other variables unchanged.

Figures 5-12 and 5-13 for 47,700 $\mathrm{ft}^{3}$ are comparable to Figures 5-6 and 5-7 for $38,800 \mathrm{ft}^{3}$. It is seen that, with the added free volume, nodes other than the first inlet node stay below $4 \%$, and the inlet node itself promptly drops below $4 \%$ as soon as the slurry gas input ends. Figure 5-13 shows that the nodes at the top of the tank remain below $4 \%$ fuel gas. Comparable figures for $83,100 \mathrm{ft}^{3}$ tank free volume are shown as Figures 5-14 and 5-15. In this case, the effect of the incoming air from the top of the tank is dissipated before reaching the waste surface and convective flow results in higher, and more erratic local concentrations that reach $11.7 \%$ (Figure 5-14). Local concentration perturbations continue at the 12.2-ft level, node 753 on Figure 5-15, but the concentration remains well below $4 \%$. At the top of the tank, $23.5 \mathrm{ft}$ above the surface, these perturbations become significantly smoothed; concentrations remain well below $4 \%$. The effects of free volume on mixing time are summarized in Table 5-5. 
WHC-SD-WM-SAR-064, Rev. 0

Figure 5-12. Gas Concentration vs. Time $-47,700 \mathrm{ft}^{3}$ Tank Free Volume, 50 Minute Gas Input Time.

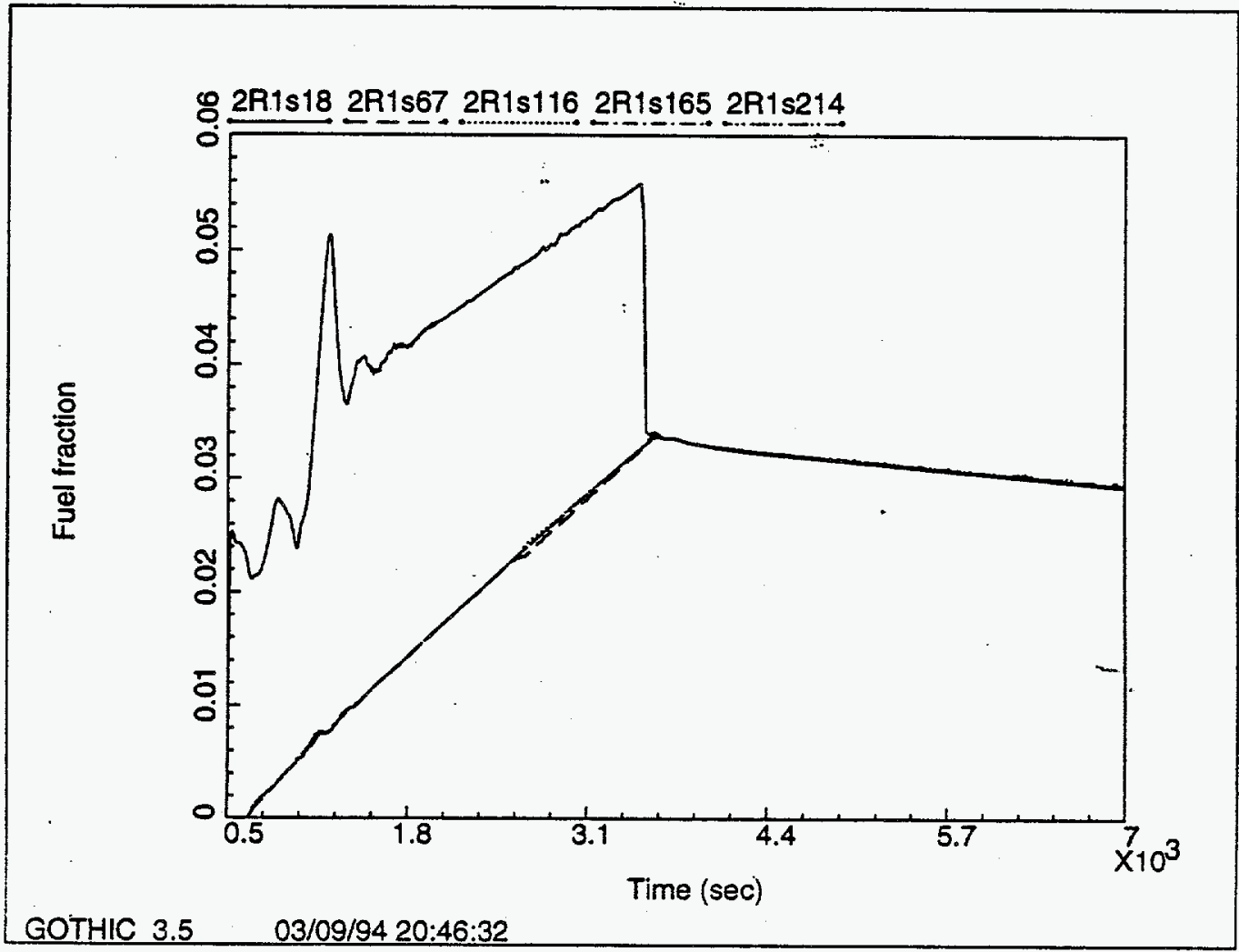

Figure 5-13. Gas Concentration vs. Time $-47,700 \mathrm{ft}^{3}$ Tank Free Volume, 50 Minute Gas Input Time.

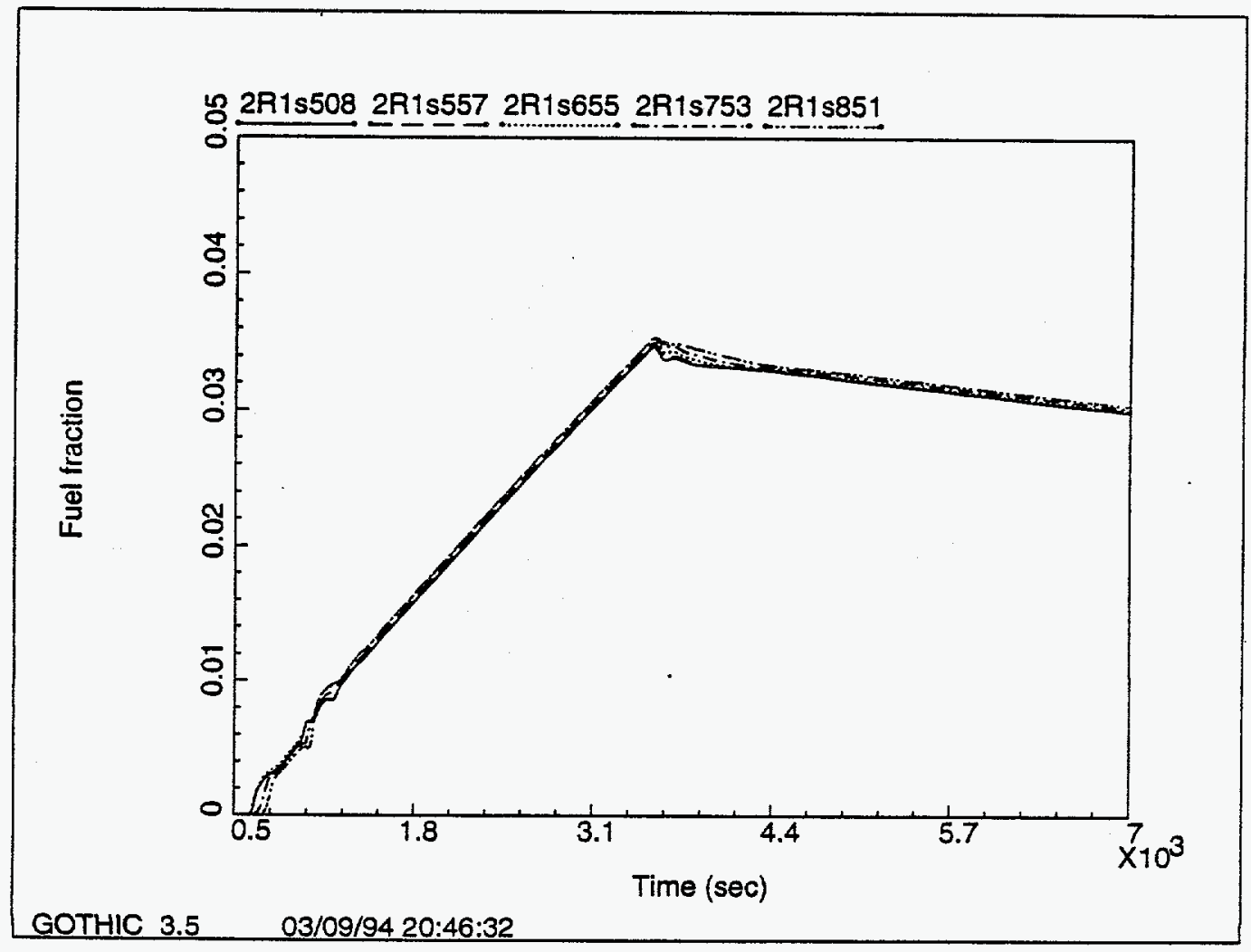


Figure 5-14. Gas Concentration vs. Time $-83,100 \mathrm{ft}^{3}$ Tank Free Volume, 50 Minute Gas Input Time.

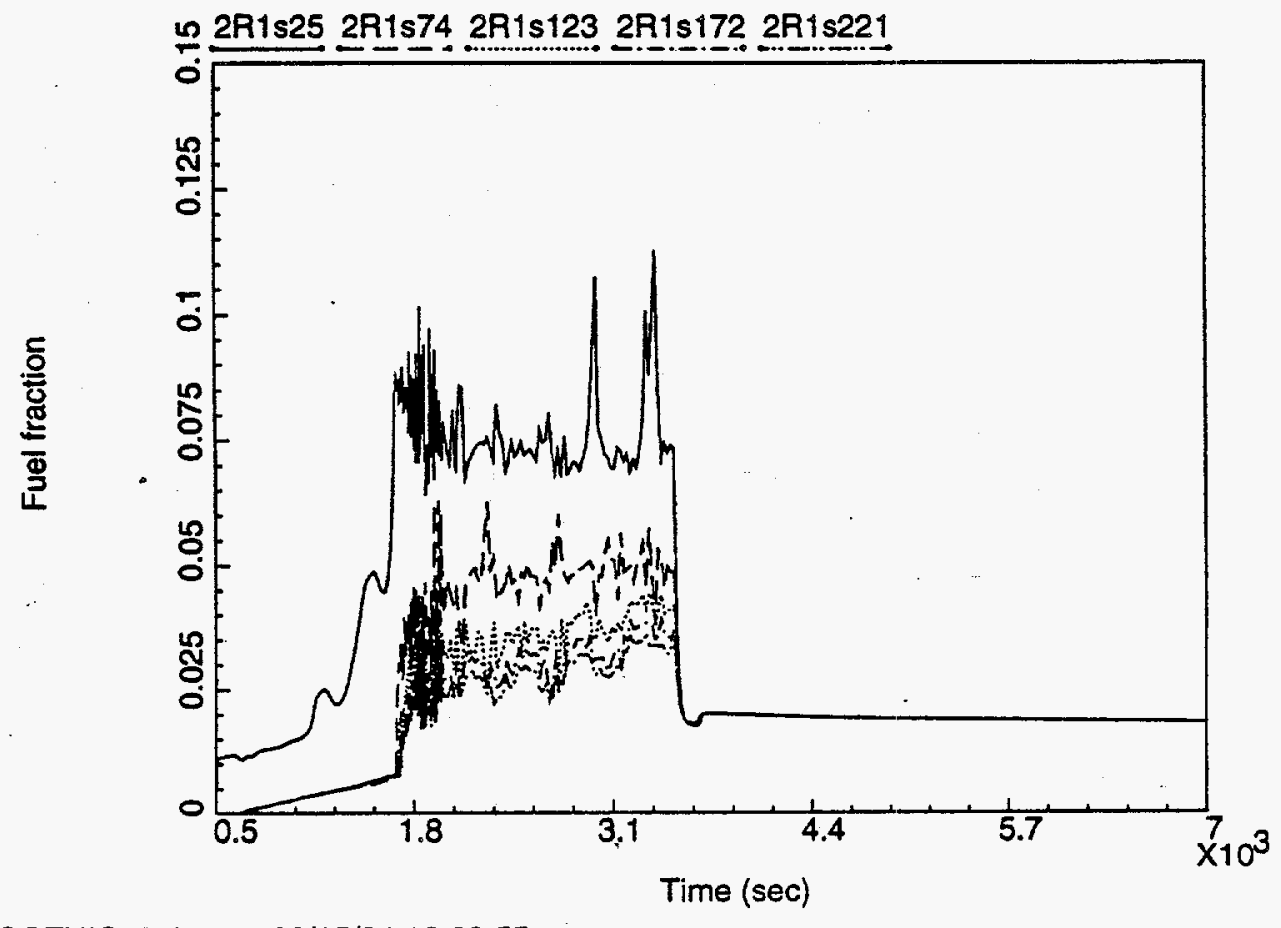

GOTHIC 3.5

$03 / 15 / 9412: 32: 55$

Figure 5-15. Gas Concentration vs. Time $-83,100 \mathrm{ft}^{3}$ Tank Free Volume, 50 Minute Gas Input Time.

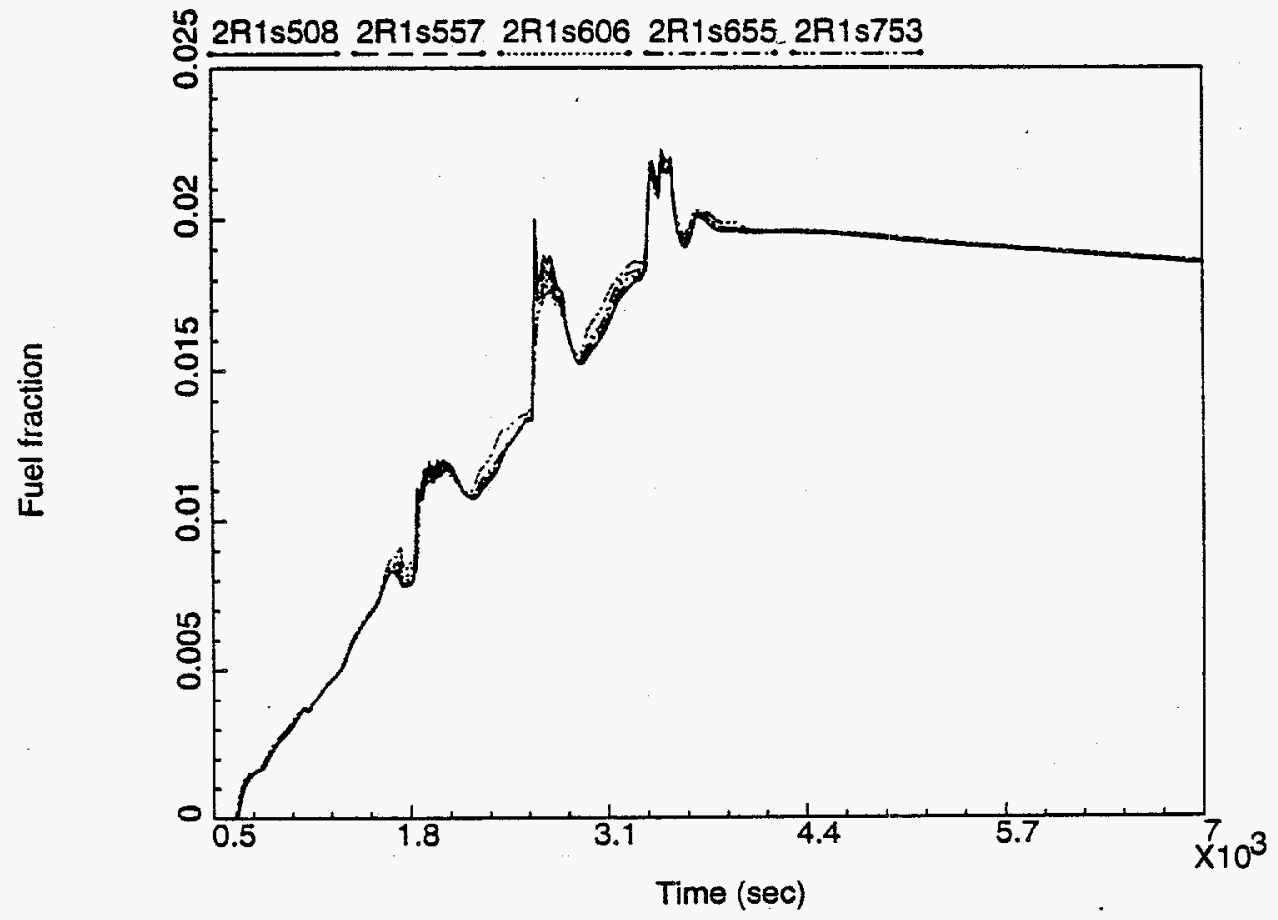


Table 5-5. Time at Risk versus Free Volume.

\begin{tabular}{|c|c|c|c|c|}
\hline $\begin{array}{c}\text { Free volume } \\
\left(\mathrm{ft}^{3}\right)\end{array}$ & $\begin{array}{c}\text { Max. conc. }(\% \\
\text { fuel) }\end{array}$ & $\begin{array}{c}\text { Time to reach } \\
4 \%(\mathrm{~min})\end{array}$ & $\begin{array}{c}\text { Time to } \\
\text { return to } 4 \% \\
(\mathrm{~min})\end{array}$ & $\begin{array}{c}\text { Total. time }> \\
4 \%(\mathrm{~min})\end{array}$ \\
\hline 38,800 & 6.1 & 9 & 68 & 59 \\
\hline 47,700 & 5.6 & 11 & 50 & 39 \\
\hline 83,100 & 11.5 & 15 & 50 & 35 \\
\hline
\end{tabular}

The last variable considered was slurry gas inlet area. The choice of $900 \mathrm{ft}^{2}$ for these studies was discussed earlier. For sensitivity testing, the mixing simulation was repeated with $100 \mathrm{ft}^{2}$ and $4,000 \mathrm{ft}^{2}$, for the 50-minute input, $38,800 \mathrm{ft}^{3}$ free volume base case. Selected result's for the $100 \mathrm{ft}^{2}$ case are shown in Figures 5-16 and 5-17, with the concentrated inlet, local concentration peaks at a relatively high value. Mixing takes place quite rapidly and, by the time the upper part of the tank is reached, concentration patterns are similar to the $900 \mathrm{ft}^{2}$ inlet case. Results for the 4,000 $\mathrm{ft}^{2}$ case are shown in Figures 5-18 and 5-19. In this case, the node next to the wall reaches a concentration of $4 \%$ fuel gas first, with somewhat more variability in the local concentrations. Concentrations in the upper part of the tank are consistent with those found in the smaller release area cases. The times at risk are summarized in Table 5-6.

Table 5-6. Time at Risk versus Gas Inlet Area.

\begin{tabular}{|c|c|c|c|c|}
\hline $\begin{array}{c}\text { Gas inlet } \\
\text { area }\left(\mathrm{ft}^{2}\right)\end{array}$ & $\begin{array}{c}\text { Max. conc. } \\
(\% \text { fuel) }\end{array}$ & $\begin{array}{c}\text { Time to reach 4\% } \\
(\mathrm{min})\end{array}$ & $\begin{array}{c}\text { Time to } \\
\text { return to } 4 \% \\
(\mathrm{~min})\end{array}$ & $\begin{array}{c}\text { Total time }>4 \% \\
(\mathrm{~min})\end{array}$ \\
\hline 100 & 38.0 & 0 & 67 & 67 \\
\hline 900 & 6.1 & 9 & 68 & 59 \\
\hline 4,000 & 6.2 & 28 & 72 & 44 \\
\hline
\end{tabular}

\subsection{SUMMARY OF MIXING RESULTS}

The mixing studies reported here show that for this set of tanks, the length of time per release event that a tank contains more than $4 \%$ flammable gas at any location in the dome space is not likely to exceed 2 hours. This time applies to the whole range of gas input times considered, which ranged from 5 minutes to 100 minutes. For the gas quantities considered, input time is not likely to be shorter than 5 minutes. The highest gas input rate observed in tank 101-SY was a level drop of 10 in. in 10 minutes in September 1992. Since most level measurements for the AW and AN tanks are 
WHC-SD-WM-SAR-064, Rev. 0

24 hours apart, reliable rate data are not available for these tanks. The onty short-term level drop data point available is a drop of 1.6 in. for tank 101-AW in 1 hour. Thus, release times up to 1.00 minutes were considered with 50 minutes adopted for the base case.

The total gas input quantity in the most sensitive parameter found for effect on time at risk. Because the concentration reaches to just a little over $4 \%$ for the base case, a small increase in gas input provides a relatively large increase in the excess that must be purged out to return the concentration to $4 \%$.

Time at risk is comparatively insensitive to free volume over the range available in this group of tanks. Although the purge time constant becomes larger as free volume increases, this effect is overcome by natural convection dispersion of fuel gas in the larger dome space. Thus, the smallest dome space shows the longest time at risk.

Time at risk is also quite insensitive to gas input area, and the value chosen for the base case does not introduce a significant bias. This analysis indicates that time at risk, defined as that time when any of the volume nodes in the model contain a fuel gas concentration greater than $4 \%$, was determined to be 59 minutes with $3,600 \mathrm{ft}^{3}$ slurry gas input and 100 minutes with $4,000 \mathrm{ft}^{3}$ gas input for a tank free volume of $38,800 \mathrm{ft}^{3}$. When the dome volume is adjusted to $35,000 \mathrm{ft}^{3}$, approximating dome space when the tank is filled to capacity, time at risk is estimated to be 62 and 112 minutes for 3,600 and $4,000 \mathrm{ft}^{3}$ slurry gas input volumes, respectively. The inlet node in the model has a volume of $150 \mathrm{ft}^{3}$ and at $4 \%$ would contain only $6 \mathrm{ft}^{3}$ of fuel gas. The time at risk was measured from the time the first node reached $4 \%$. However, ignition at that time, if it were possible, would have trivial consequences. The time that a significant volume of gas (more than 100$200 \mathrm{ft}^{3}$ ) is present is somewhat less than the times quoted above. Moreover, the tank with the largest slurry gas release, tank 104-AN, has a larger free volume than the base case used above to generate the risk times.

Nevertheless, for risk quantification in Section 8.0 of this report, time at risk was taken as 200 minutes per year per tank to bound uncertainties.

\subsection{CONCENTRATION DISTRIBUTION}

In addition to showing the length of time flammable gas concentrations would exist in these tanks, the mixing simulation also shows the quantities of gas above the LFL. The results are given as a function of gas input time and the other independent variables considered in the previous section. The results are summarized in Tables 5-7 through 5-10.

Table 5-7 shows the effect of fuel gas input rate on concentration distribution. It is seen that as the gas input is spread out in time, the maximum concentrations drop off rapidly. The gas volumes above $5 \%$ are small for the base case of 50 minutes. For example, the $180 \mathrm{ft}^{3}$ of tank vapor space 
WHC-SD-WM-SAR-064, Rev. 0

Figure 5-16. Gas Concentration vs. Time $-100 \mathrm{ft}^{2}$ Gas Inlet Area, 50 Minute Gas Input Time.

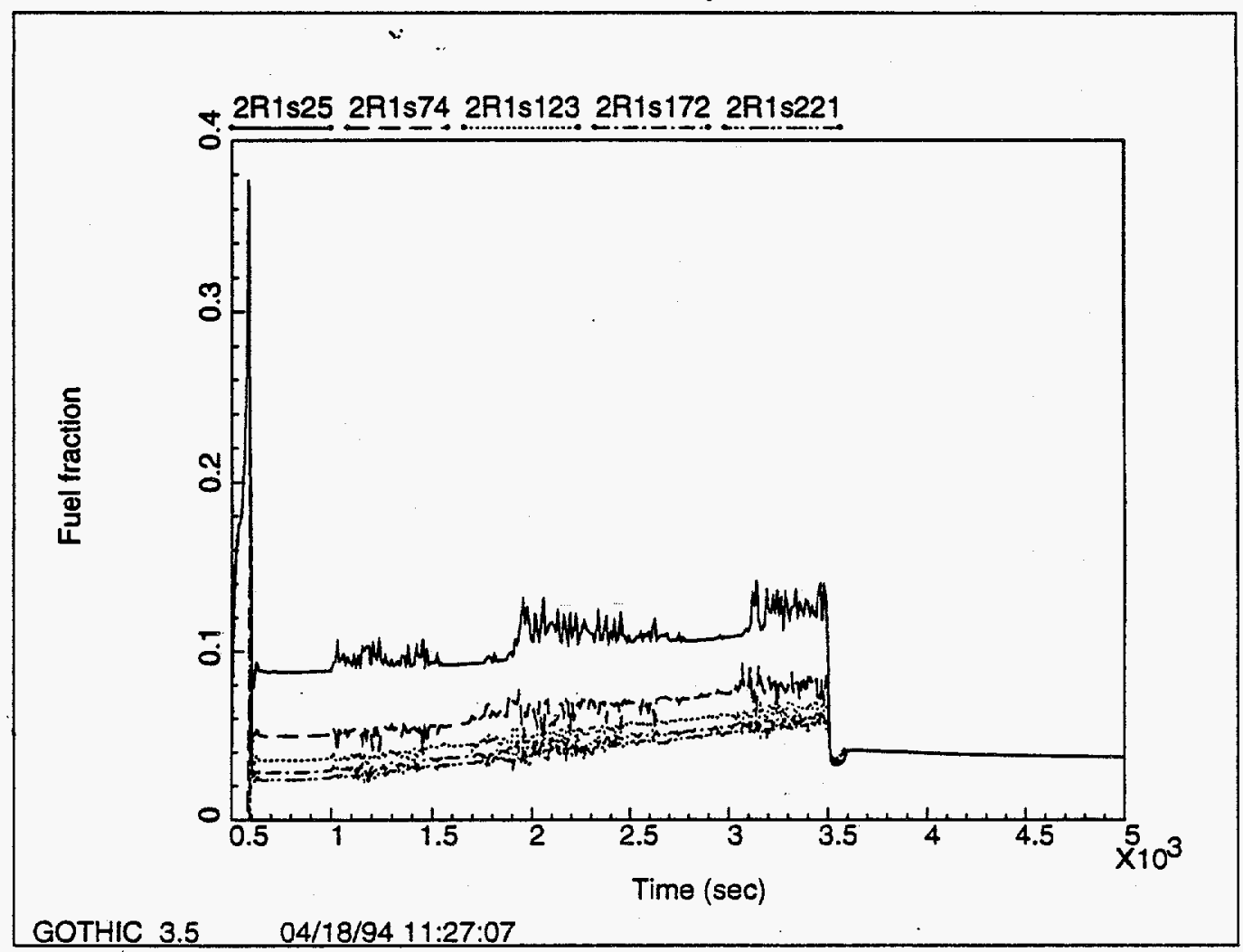

Figure 5-17. Gas Concentration vs. Time $-100 \mathrm{ft}^{2}$ Gas Inlet Area, 50 Minute Gas Input Time.

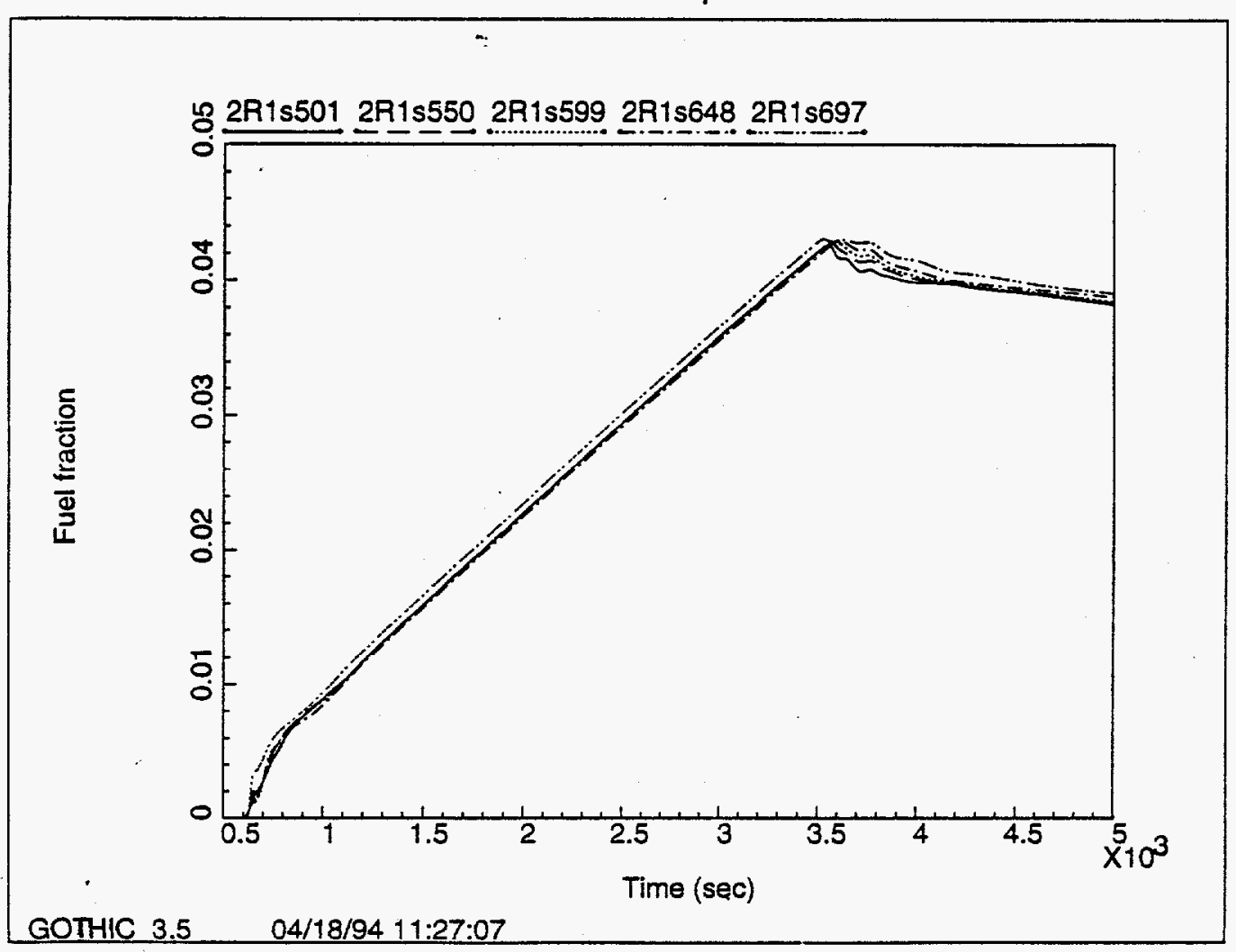


WHC-SD-WM-SAR-064, Rev. 0

Figure 5-18. Gas Concentration vs. Time $-4,000 \mathrm{ft}^{2}$ Gas Inlet Area, 50 Minute Gas Input Time.

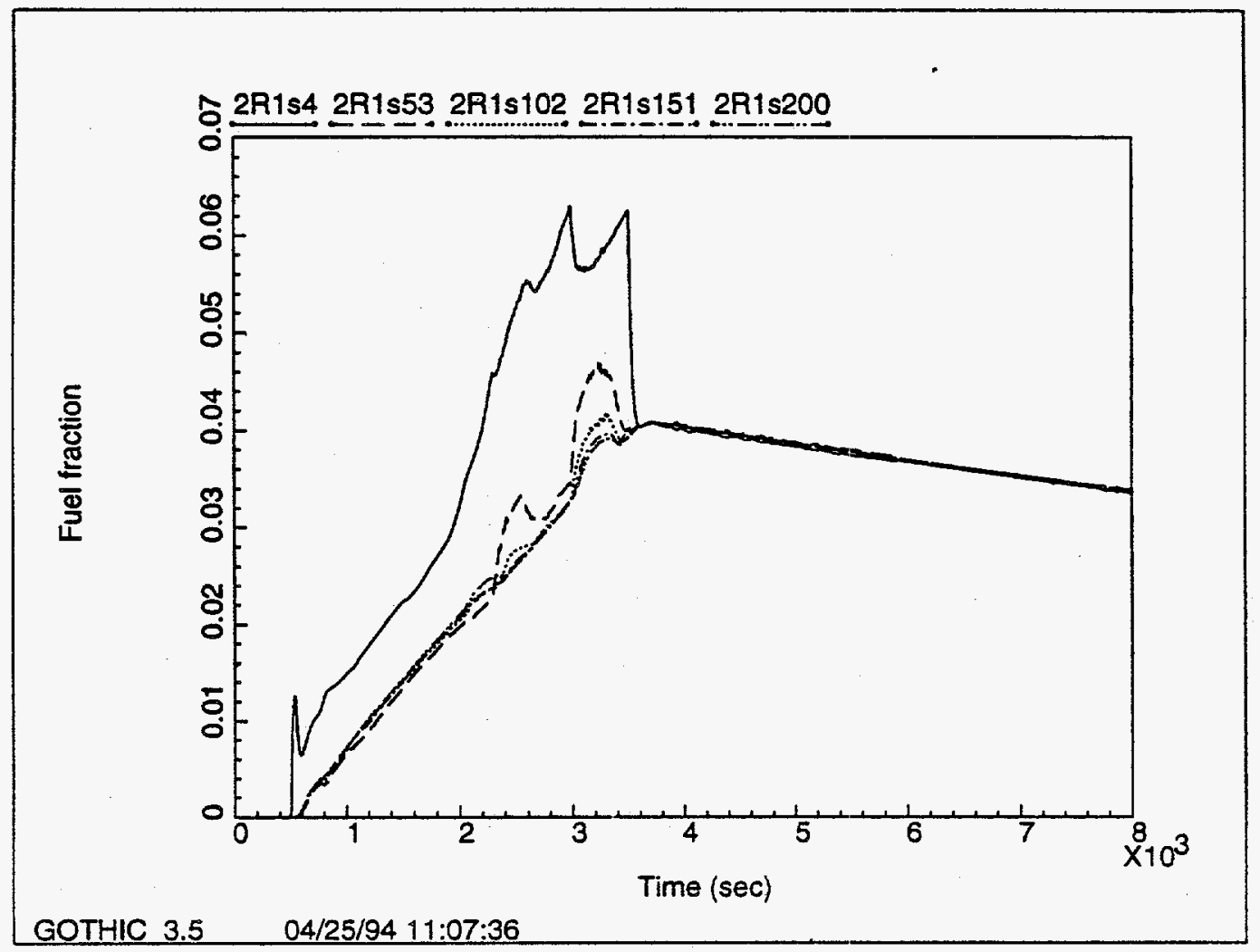

Figure 5-19. Gas Concentration vs. Time $-4,000 \mathrm{ft}^{2}$ Gas Inlet Area, 50 Minute Gas Input Time.

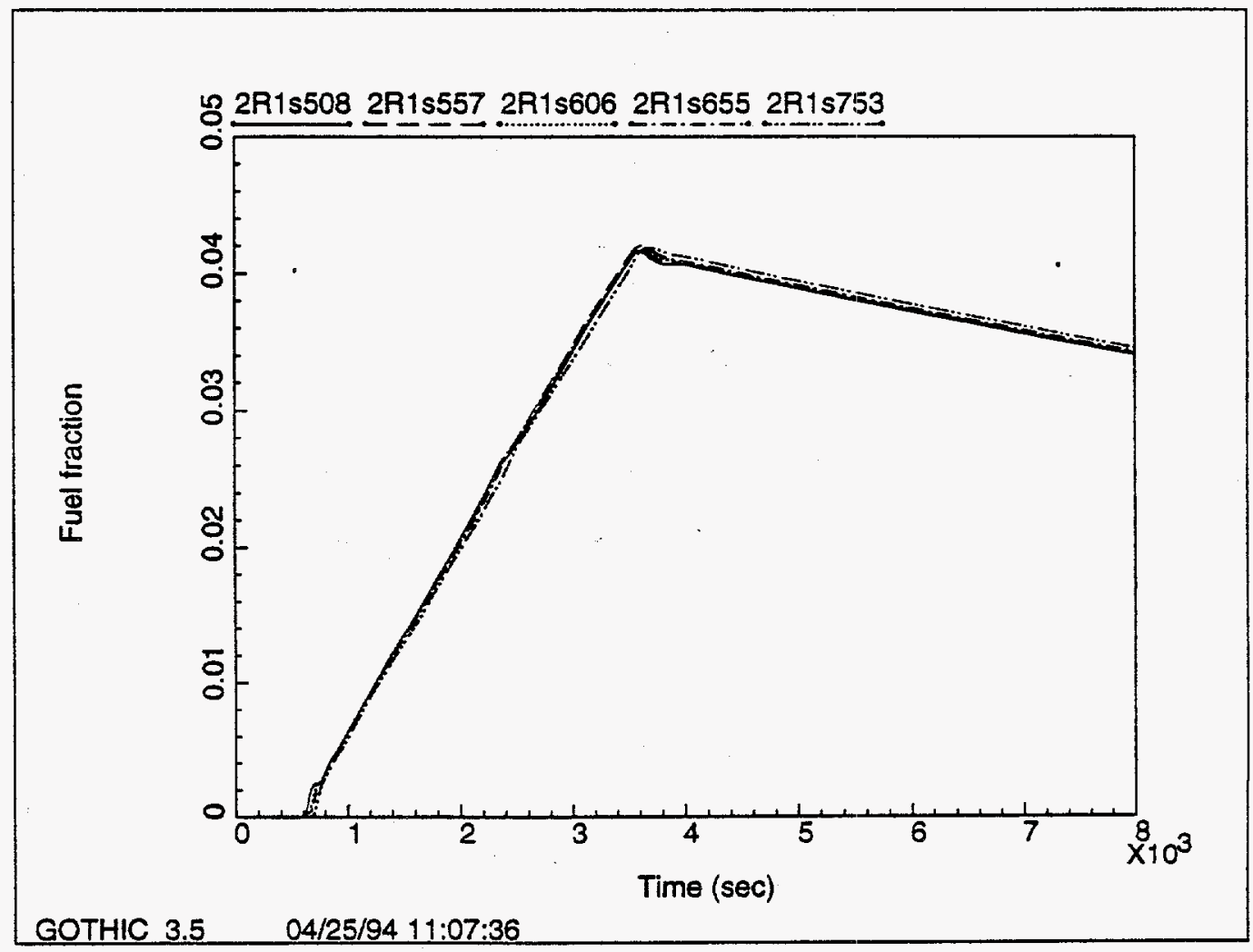


at a concentration greater than $5 \%$ contains less than $10 \mathrm{ft}^{3}$ of fuel (hydrogen and ammonia mixture). This is less than $1 \%$ of the total fuel gas in the tank. The remainder is at a concentration of about $4.2 \%$. Lean mixtures such as this produce only about one third of the adiabatic burn energy owing to incomplete combustion.

The gas concentration distributions in these tables have been conservatively defined. If a concentration spike reaches a node, that node is considered to contain that concentration for all time. The maximum concentrations seen by any node are tabulated and summed to get the total in a particular concentration bin even though the maximums may occur at different times.

The effect of tank free volume on gas concentrations is shown in Table 5-8. For the burp sizes considered here, increasing the tank free volume decreases flammable mixture volume. The $180 \mathrm{ft}^{3}$ with a high concentration in the $83,100 \mathrm{ft}^{3}$ case is a result of short duration concentration spikes.

The effect of gas input area on concentration distribution is shown in Table 5-9. The $100 \mathrm{ft}^{2}$ injection area shows small amounts of gas at higher concentrations than the other two cases. However, in all cases, more than 97\% of the flammable gas is present only as a dilute mixture that would be barely flammable. Table 5-10 shows the effect of increasing the total gas input from 3,600 to $4,000 \mathrm{ft}^{3}$. The bulk of the fuel ends up at a concentration of $4.7 \%$ instead of $4.2 \%$, still a low concentration that would burn with 10 w thermal efficiency if ignited.

It should be noted that if the slurry gas contains $20 \% \mathrm{NH}_{3}$, as described in Section 5.1, the LFL is $5.7 \%$ fuel gas $\left(\mathrm{H}_{2}+\mathrm{NH}_{3}\right)$. So concentration fractions of 4 to $5 \%$ fuel gas are really not flammable. However, if the fuel gas were all hydrogen, then the LFL is $4 \%$ fuel gas and upward propagation is possible at concentrations of 4.2 to $4.7 \%$. Therefore, the foregoing conclusions are applicable to slurry gas mixtures which might contain $50 \%$ hydrogen.

From the gas distribution studies, it can be seen that dilution occurs nearly in balance with the gas input rate. This observation applies to the range of parameters likely to be encountered in this group of tanks, based on current information.

This behavior suggests that application of hydrogen burn efficiency studies should be considered in hazard evaluation of these and similar tanks. A brief review of some flammability data is provided in Section 5.6. 
Table 5-7. Effect of Gas Input Rate on Concentration Distribution $\left(38,800 \mathrm{ft}^{3}\right.$ free space).

\begin{tabular}{|c|c|c|c|c|}
\hline \multirow{2}{*}{$\begin{array}{c}\text { Concentration } \\
\text { (vol\%) }\end{array}$} & 5 & 10 & 50 & 100 \\
\hline$>10$ & 420 & 540 & 0 & 0 \\
\hline $8-10$ & 200 & 200 & 0 & 0 \\
\hline $7-8$ & 190 & 40 & 0 & 0 \\
\hline $6-7$ & 380 & 190 & 160 & 0 \\
\hline $5-6$ & 7,528 & 2,350 & 20 & 0 \\
\hline $4-5$ & 19,880 & 30,450 & 38,620 & 800 \\
\hline Total $>4 \%$ & 28,600 & 33,770 & 38,800 & 80 \\
\hline
\end{tabular}

Table 5-8. Effect of Free Volume on Concentration Distribution, 50 Minute Input: Time.

\begin{tabular}{|c|c|c|c|}
\hline \multirow{2}{*}{$\begin{array}{c}\text { Concentration } \\
\text { (vol\%) }\end{array}$} & \multicolumn{3}{|c|}{ Tank Dome Volume $\left(\mathrm{ft}^{3}\right)$} \\
\cline { 2 - 4 } & 38,800 & 47,700 & 83,100 \\
\hline$>10$ & 0 & 0 & $20^{*}$ \\
\hline $8-10$ & 0 & 0 & $160 *$ \\
\hline $7-8$ & 0 & 0 & 0 \\
\hline $6-7$ & 160 & 0 & 20 \\
\hline $5-6$ & 20 & 160 & 0 \\
\hline $4-5$ & 38,620 & 20 & 340 \\
\hline $3-4$ & 0 & Ca. 47,520 & 0 \\
\hline $2-3$ & 0 & 0 & Ca. 82,560 \\
\hline
\end{tabular}

*Mainly short duration spikes. 
Table 5-9. Effect of Gas Input Area on Concentration Distribution $\left(38,800 \mathrm{ft}^{3}\right.$ free space).

\begin{tabular}{|c|c|c|c|}
\hline \multirow{2}{*}{$\begin{array}{c}\text { Concentration } \\
\text { (vo1\%) }\end{array}$} & \multicolumn{3}{|c|}{ Gas release area $\left(\mathrm{ft}^{2}\right)$} \\
\cline { 2 - 4 } & 100 & 900 & 4,000 \\
\hline$>10$ & 40 & 0 & 0 \\
\hline $8-10$ & 20 & 0 & 0 \\
\hline $7-8$ & 20 & 0 & 0 \\
\hline $6-7$ & 180 & 160 & 300 \\
\hline $5-6$ & 680 & 20 & 320 \\
\hline $4-5$ & 37,860 & 38,620 & 38,180 \\
\hline
\end{tabular}

Table 5-10. Effect of Total Gas Input on Concentration Distribution $\left(38,800 \mathrm{ft}^{3}\right.$ free space).

\begin{tabular}{|c|c|c|}
\hline \multirow{2}{*}{$\begin{array}{c}\text { Concentration } \\
(\text { vol\%) }\end{array}$} & \multicolumn{2}{|c|}{ Gas input $\left(\mathrm{ft}^{3}\right)$} \\
\cline { 2 - 3 } & 3,600 & 4,000 \\
\hline$>10$ & 0 & 0 \\
\hline $8-10$ & 0 & 0 \\
\hline $7-8$ & 0 & 160 \\
\hline $6-7$ & 160 & 0 \\
\hline $5-6$ & 20 & 20 \\
\hline $4-5$ & $38,620^{1}$ & $38,620^{2}$ \\
\hline
\end{tabular}

${ }^{1}$ Mainly Ca. $4.2 \%$.

${ }^{2}$ Mainiy Ca. $4.7 \%$.

\subsection{FLAMMABILITY DATA}

The failure of lean hydrogen mixtures to produce calculated adiabatic burn pressures is well established. The deviation between actual and calculated burn pressures has been quantified in Cashdollar et al. (1993), Hertzberg (1983), P7ys (1993), and others. The actual results are affected by energy of ignition, the volume of the test vessel, and the hydrodynamic condition of the mixture (i.e., whether quiescent or turbulent). A thorough examination of these variables is beyond the scope of this report. However, consideration of the data cited suggests that the lean mixtures likely to be encountered in waste tanks will not burn completely. 
Table 5-11 (based on Cashdollar et al. 1993, Figure 39) shows the ratios of experimental-to-adiabatic burn pressure data for stoichiometric hydrogennitrous oxide mixtures, remainder argon. The experimental data were obtained from turbulent mixtures. These data should be conservative when applied to hydrogen-nitrous oxide air mixtures, since the heat capacity of monatomic argon is $60 \%$ of that of diatomic air. Thus, higher temperatures, and hence pressures, should result from burning a given amount of hydrogen in the tests. These data are likely to provide reasonable estimates of pressure reduction, but numerous variables are involved, and additional investigation is required before taking credit for this effect. It is seen that adiabatic burn pressure calculations are likely to overpredict consequences by factors of about two to three in lean mixtures.

Table 5-11. Burn Pressure Ratios:

Experimental/Calculated.

\begin{tabular}{|c|c|}
\hline Hydrogen conc. (\%) & Pressure ratio \\
\hline 4.5 & 0.36 \\
\hline 5 & 0.38 \\
\hline 6 & 0.45 \\
\hline 7 & 0.53 \\
\hline
\end{tabular}




\subsection{PLUME BURN MODEL}

As discussed in Section 4.0 , if the released gas is completely mixed with the large dome air space, its concentration is below the LFL and will not burn. However, it is conceivable that a rapid release could be ignited before complete mixing occurs. This event is called a plume burn because unmixed gas in a limited region in the dome space burns.

The actual burning of a plume is a very complex process involving a burning front, which propagates throughout the gas and is pushed by the hot expanding combustion products. This will be approximated here by a conservative model that heats the gas by self-combustion, expands as a result of heating, and loses heat primarily by thermal radiation. This model investigates combustion of a piume of gas, which heats a crust that is floating on the top surface of the waste. With sufficient heating, the plume burn could be an ignition source for a reactive crust. The possibility of this occurrence is investigated in Section 7.2. This section describes the details of the plume burn modeling.

\subsection{GAS MODEL}

A gas plume is assumed to be released into the air-filled dome space at $1 \mathrm{~atm}$ pressure. Mixing with the dome air is treated by increasing the size of the plume and reducing the plume gas fractions. No further mixing is allowed during the burning process. The gas is burned with a prescribed burning time, the heat of combustion is added to the plume which expands so that the pressure remains equal inside the plume and within the tank. The final volume of the plume may be many times the initial size. The gaseous combustion products contain water vapor which radiates energy out of the plume to the tank surfaces, including the crust. A simplified convective heat loss is included, but the loss is small when compared with thermal radiation.

The thermodynamic equations for the gas plume and air are as follows:

Temperature

$$
\frac{\dot{T}}{T}=\frac{\dot{Q}}{m C_{v} T}-(\gamma-1) \frac{\dot{V}}{V}
$$


Pressure

$$
\frac{\dot{P}}{p}=\frac{\dot{T}}{T}+\frac{\dot{N}}{N}-\frac{\dot{V}}{V}
$$

where the plume gas conditions are described by:

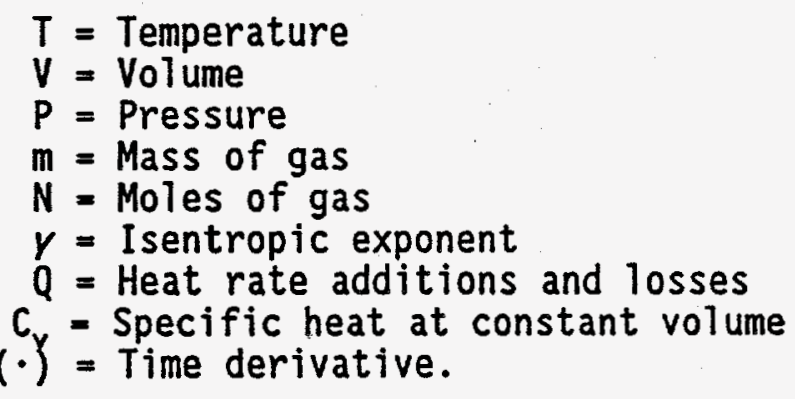

Equations 6-1 and 6-2 are written for both the plume and dome air. Using the condition that pressure remain the same in both regions, and that volume increase in the plume equals the volume decrease of the air space, these equations may be solved for each time step. Further details of this derivation and the predictor-corrector method of solving the differential equations are shown in Appendix A.

\subsection{GAS ENERGY OF COMBUSTION}

The slurry gas is a multi-component mixture of fuel, oxidant, and other nonreacting gases. The combustion process may proceed along different paths depending on temperature and gas concentrations. The approach here is to maximize the heat of combustion which gives the highest product temperatures, pressures, and heat transferred to the crust.

Maximum conditions are accomplished by assuming the reactions occur in a specific order. That is, the oxidizer, nitrous oxide, produces the largest exothermic energy and is used to react the most energetic fuels first. Then, when the nitrous oxide is consumed, the remainder of the fuel gases are reacted with oxygen from the air.

The chemical reactions are ordered as follows:

$$
\mathrm{CH}_{4}+4 \mathrm{~N}_{2} \mathrm{O} \stackrel{1,130 \mathrm{~kJ}}{\longrightarrow} \mathrm{CO}_{2}+2 \mathrm{H}_{2} \mathrm{O}+4 \mathrm{~N}_{2}
$$


WHC-SD-WM-SAR-064, Rev. 0

$$
\begin{gathered}
\mathrm{NH}_{3}+\frac{3}{2} \mathrm{~N}_{2} \mathrm{O} \stackrel{439 \mathrm{~kJ}}{\longrightarrow} \frac{3}{2} \mathrm{H}_{2} \mathrm{O}+2 \mathrm{~N}_{2} \\
\mathrm{CO}+\mathrm{N}_{2} \mathrm{O} \stackrel{365 \mathrm{~kJ}}{\longrightarrow} \mathrm{N}_{2}+\mathrm{CO}_{2} \\
\mathrm{H}_{2}+\mathrm{N}_{2} \mathrm{O} \stackrel{324 \mathrm{~kJ}}{\longrightarrow} \mathrm{H}_{2} \mathrm{O}+\mathrm{N}_{2} \\
\mathrm{CH}_{4}+2 \mathrm{O}_{2} \stackrel{803 \mathrm{~kJ}}{\longrightarrow} \mathrm{CO}_{2}+2 \mathrm{H}_{2} \mathrm{O} \\
\mathrm{NH}_{3}+\frac{3}{4} \mathrm{O}_{2} \stackrel{317 \mathrm{~kJ}}{\longrightarrow} \frac{3}{2} \mathrm{H}_{2} \mathrm{O}+\frac{1}{2} \mathrm{~N}_{2} \\
\mathrm{CO}+\frac{1}{2} \mathrm{O}_{2} \stackrel{283 \mathrm{~kJ}}{\longrightarrow} \mathrm{CO}_{2} \\
\mathrm{H}_{2}+\frac{1}{2} \mathrm{O}_{2} \stackrel{242 \mathrm{~kJ}}{\longrightarrow} \mathrm{H}_{2} \mathrm{O}
\end{gathered}
$$

The heat of reaction energies are calculated using heats of formation and given in $\mathrm{kJ} / \mathrm{mole}$ of fuel gas. In addition, the number of moles of product gases may be different than the moles of reactants. An example of the results is shown in Table 6-1 for the best estimate composition of slurry gas which has been mixed with an equal volume of air.

Note an initial water vapor fraction of 0.012 was incorporated into the nitrogen quantity as an unreacting gas. This has very little effect on the results.

Applying Equations 6-3 through 6-10 to the reactants in Table 6-1 produces a heat of combustion of $128 \mathrm{~kJ} / \mathrm{mole}$ of slurry gas, as shown in Table 4-2. In addition, the products moles have increased by the factor 1.002 , showing the change in molar quantities is very small for this composition. 
Table 6-1. Composition Fractions for Best Estimate Gas.

\begin{tabular}{|c|c|}
\hline Reactants & Products \\
\hline $\mathrm{H}_{2}=0.14385$ & $\mathrm{H}_{2} \mathrm{O}=0.22896$ \\
\hline $\mathrm{N}_{2} \mathrm{O}=0.12225$ & $\mathrm{CO}_{2}=0.00299$ \\
\hline $\mathrm{NH}_{3}=0.05475$ & $\mathrm{O}_{2}=0.04890$ \\
\hline $\mathrm{CH}_{4}=0.00175$ & $\mathrm{~N}_{2}=0.71915$ \\
\hline $\mathrm{CO}=0.00125$ & -- \\
\hline $\mathrm{O}_{2}=0.105$ & -- \\
\hline $\mathrm{N}_{2}=0.57115$ & -- \\
\hline
\end{tabular}

\subsection{RADIATION HEAT TRANSFER}

The hot combustion gases radiate heat to the tank and crust, primarily because of the water vapor content. An effective heat transfer coefficient to the crust may be expressed as Equation 6-11.

$$
h_{r}=\frac{\dot{q}}{\Delta T}=\frac{\sigma \epsilon\left(T_{g}^{4}-T_{w}^{4}\right)}{T_{g}-T_{w}}
$$

where:

$h_{r}=$ Effective radiation heat transfer coefficient

$\dot{q}_{r}=$ Radiation heat flux to crust

$\sigma=$ Stefen-Boltzmann coefficient

$\epsilon=$ Emissivity

$T_{g}=$ Gas temperature, absolute

$T_{W}^{g}=$ Crust temperature, absolute.

The emissivity $\epsilon$ is taken as the emissivity of the water vapor which is dependent on the partial pressure $P_{4}$ and the effective radiation path length, L (Jakob 1957). The partial pressure remains a constant fraction of the total pressure since the water vapor fraction of the combustion products is fixed. The products also contain a small amount of $\mathrm{CO}_{2}$ which is a good radiator. This is incorporated into the water vapor fraction to maintain conservatism. The radiation path length is based on a spherical plume with the appropriate burned gas volume, which varies during the heat-up and cooldown processes. 
The gas emissivity is obtained from Jakob (1957). Emissivity values based on the product $P_{W} L$ and gas temperatures are tabulated for the computer program use. Interpolated values are calculated as the gas temperature changes during the plume cooling following completion of the burn.

It is also necessary to make a correction to the emissivity values calculated above because of the effect from total pressure. This correction is also obtained from Jakob (1957). The correction multipliers for a total pressure $1 \mathrm{~atm}$ or greater were curve fit for each $P_{w} L$ value. Interpolations were performed for intermediate values of $P_{W} L$.

The radiation heat transfer rates, when calculated as described, represents that occurring on the surface of a spherical plume. This is considered to be the reference case.

\subsection{CONVECTIVE HEAT TRANSFER}

Heat transfer from the hot gas to the surroundings may also occur by convection. Because these rates are small when compared with thermal radiation, the following simple relationship is used:

$$
\dot{q}_{c}=h_{c}\left(T_{g}-T_{s}\right)
$$

where:

$$
\begin{aligned}
& \dot{\mathrm{q}}_{c}=\text { Heat transfer rate from convection } \\
& \mathrm{h}_{c}=\text { Convection heat transfer coefficient } \\
& \mathrm{T}_{g}=\text { Gas temperature } \\
& \mathrm{T}_{s}=\text { Surroundings temperature. }
\end{aligned}
$$

This completes the description of the model for analyzing the plume burn and heat transfer to the crust. The chemical reactions which result at different depths in the crust are dependent on local crust temperature histories. These temperatures and reactions are computed by using an existing transient conduction and chemical reaction code (Fox et al. 1992) which is coupled to the heat source represented by the plume burn model. Considerations necessary for adapting this code to the present problem are described next. 
WHC-SD-WM-SAR-064, Rev. 0

This page intentionally left blank. 
WHC-SD-WM-SAR-064, Rev. 0

\subsection{CRUST REACTIONS}

A plume burn provides a source of high temperature gas which could heat the crust surface to high temperatures for a short time period. Chemical reactions can occur, which add more heat to the material. If the crust is sufficiently reactive, such reactions could propagate until the fuel is consumed. This section discusses the basis for selecting the crust reactivity to be used in the computer analysis. This is followed by selected cases using best estimate and conservative gas mixtures and assumptions. The section will be completed by an analysis that evaluates the margin between the conservative case and the onset of a propagating reaction.

\subsection{CHEMICAL KINETICS}

The exothermic reactions which might occur in the crust are complex and the characterization should be obtained by experiments. Adiabatic calorimetry has been performed for crust samples from tank 101-sY and the results were used to assess the possibility of crust burning (Fox et al. 1992). There have been no such measurements for crust from the tanks considered in this report, so some assumptions and extrapolations will need to be made. This section discusses the tank 101-sy calorimetry and the assumptions necessary to apply these data to other tanks.

\subsubsection{Adiabatic Calorimetry Tests}

Recent data for real waste samples. withdrawn from tank 101-SY (Bechtold 1992) provide a new database and permit a more realistic evaluation of crust reactions. These tests involve electrically heating comparatively large samples ( 10 to $15 \mathrm{~g}$ ) of a reactive material under conditions of low heat loss, i.e., nearly adiabatic. Under such conditions, the effects of exothermic reactions can be observed by measuring how rapidly the sample self-heats and deviates from the slow electrical heating baseline. Specific objectives of the test that are important to crust burn analysis are the following.

1. Determine reaction onset temperature. This is the temperature at which a measurable exothermic reaction is first noted.

2. Determine the total temperature rise of the material caused by the chemical reaction, presumably resulting from the TOC present. This temperature rise is proportional to the reaction exotherm expressed in calories per gram. The maximum temperature rise corresponds to the total energy released during the complete reaction.

3. Determine the rate of temperature rise caused by the reaction, as a function of temperature. This allows heat generation rates to be calculated as a function of temperature. 
An important aspect of adiabatic calorimetry tests is that reaction exotherms are measured in dry materials. The endotherm caused by water evaporation, which can be significant, is excluded from these tests.

Consequently, reaction kinetics based on these test results should overpredict the amount of energy released by these reactions because the suppressing effect of the water endotherm is not included. However, effects of water may be incorporated in the computer simulation by increasing the specific heat at water evaporation temperatures. As discussed later, this report adopts a minimum water content of $10 \%$, similar to prior analysis.

Further details about the calorimetry. tests and analysis of the data may be found in Fox et a1. $(1992,1993)$.

\subsubsection{Measured Crust Reactivity for Tank 101-SY}

The calorimetry provides a relationship for the temperature rise rate as a function of temperature. This relationship is usually highly nonlinear. The volumetric heating rate is obtained by multiplying the temperature rise rate by density and specific heat. Six tests on waste samples were selected to characterize the tank waste exothermic behavior. Four composite samples were obtained from various tank levels and two were from the crust (Fox et al. 1992). The results of the calorimetry are shown in Figure 7-1. The most reactive sample, labeled 2 , even though it was not from the crust, was selected to characterize the crust in tank 101-SY. This curve was simulated by computing temperature dependent temperature rise rates which are then converted to equivalent heating rates. This characterization is shown in Table 7-1.

Table 7-1. Kinetic Parameters for Tank 101-SY.

\begin{tabular}{|c|c|c|}
\hline $\begin{array}{c}\text { Temperature } \\
\left({ }^{\circ} \mathrm{C}\right)\end{array}$ & $\begin{array}{c}\text { Calorimetry } \\
\text { concentration } \\
\text { ratio }\left(\mathrm{C} / \mathrm{C}_{\mathrm{o}}\right)\end{array}$ & $\begin{array}{c}\mathrm{Q}_{\text {genz }} \\
\left(\mathrm{KW}^{\mathrm{g}} / \mathrm{m}^{3}\right)\end{array}$ \\
\hline 150 & 1.0 & 12 \\
\hline 245 & 0.753 & 174 \\
\hline 301 & 0.55 & 138 \\
\hline 358 & 0.343 & 190 \\
\hline 390 & 0.224 & 272 \\
\hline 440 & 0.0256 & 131 \\
\hline $\mathrm{Q}_{\max }=4.6$ & $10^{8} \mathrm{~J} / \mathrm{m}^{3}$. & \\
\hline
\end{tabular}




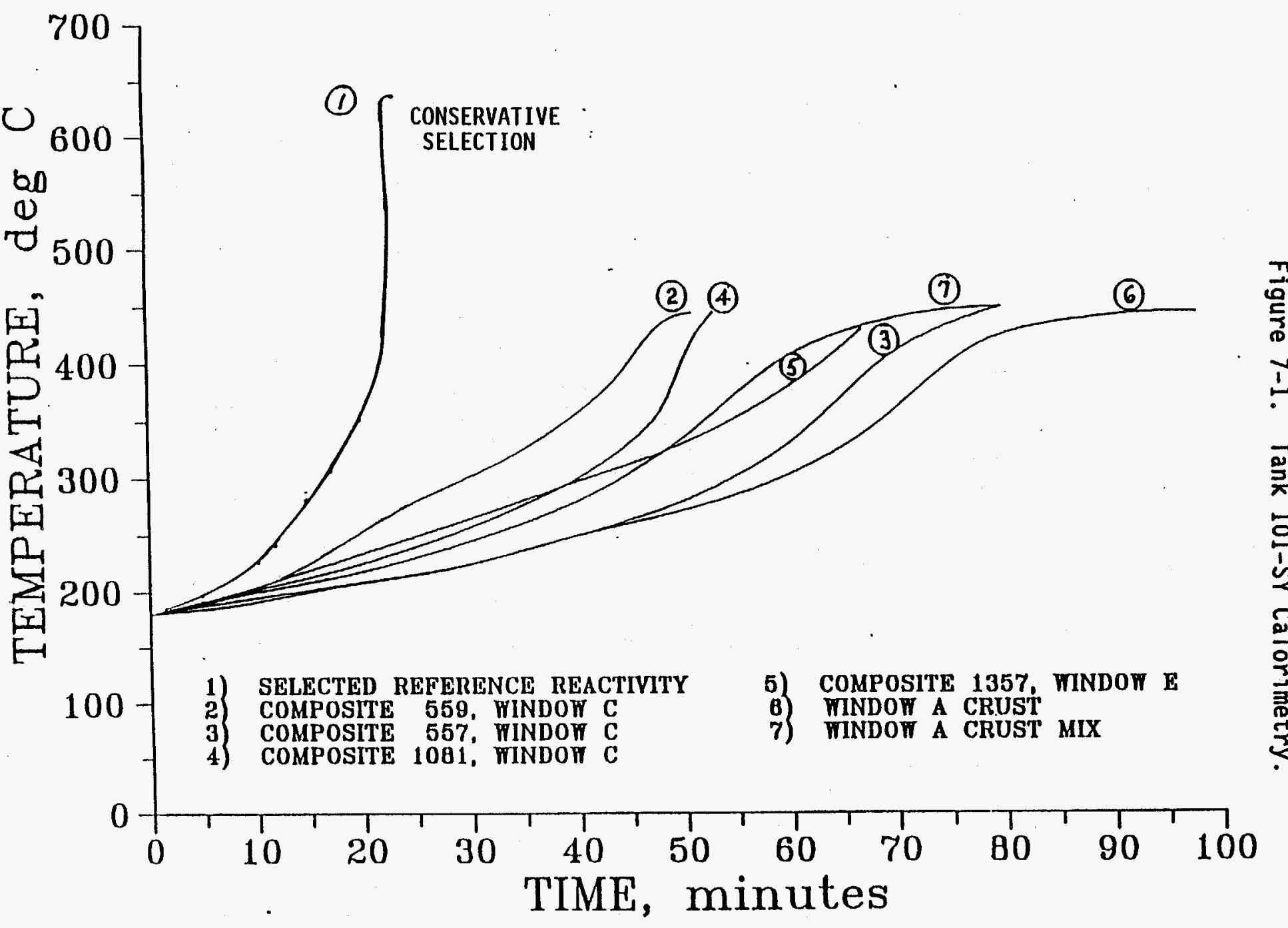


The heat generation relationship was assumed to follow an Arrhenius type reaction:

$$
\dot{Q}=\left[\frac{C}{C_{0}}\right]^{n} A \exp \left(-E_{0} / R T\right)
$$

where:

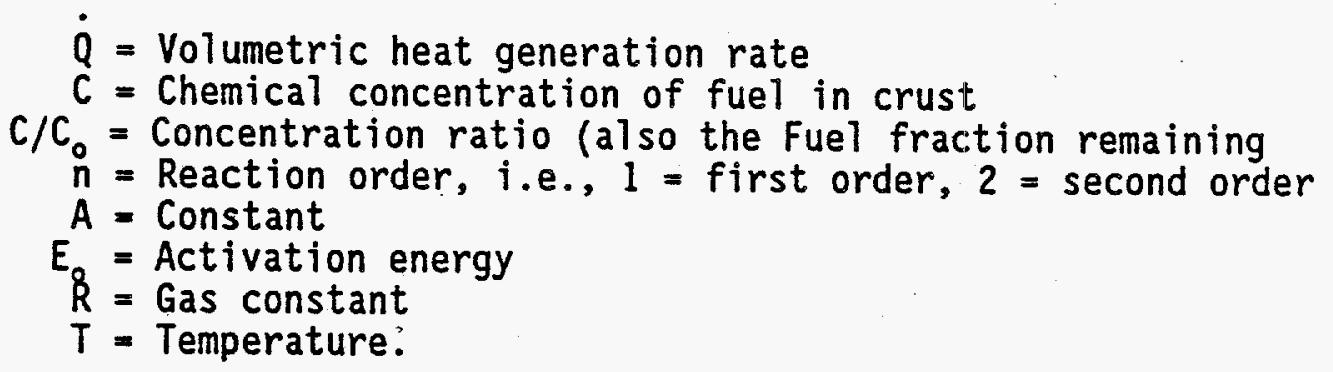

Heat generation rates shown in Table 7-1 were fit by applying the first order form of Equation 7-1 for each temperature increment, which provides a functional relationship for the crust temperature dependent volumetric heat generation rate which was incorporated into the computer model.

At first, it may seem strange to include the calorimetry chemical concentration ratio $\left(C / C_{0}\right)$, as a parameter in the characterization. This represents the chemical reactant concentration when the listed temperatures were reached for the calorimetry tests. These are used to calculate the "zero order" coefficients, i.e., reaction rates if there were no chemical consumption. When the zero order coefficients are applied for a crust burn calculation, the correct consumption is also calculated based on the integrated heat generation during the run. The heat generation rate is then corrected using this computed consumption.

Table 7-1 also shows the exothermic energy, $Q_{\max }$, based on the total temperature rise. The relationship relating the fuel fraction remaining and heat generated for each point in the crust is shown as Equation 7-2.

$$
\frac{C}{C_{0}}=1-\frac{\Sigma Q_{\text {gerl }} \Delta t}{Q_{\max }}
$$

\subsubsection{Basis for Extrapolation of Calorimetry}

To apply the calorimetry results from tank 101-SY to other tanks, it is necessary to consider the significance of chemistry differences. The percentage of TOC in the crust may be the most important parameter when considering exothermic reactions and the possibility of propagating reactions. 
It is implicitly assumed there is ample oxidant to react with the TOC. Quantities of nitrates and nitrites reported in Section 3.3 support this assumption.

The exothermic energy released during a crust reaction is expected to be no worse than directly proportional to TOC values. We shall use this approach and assume that $Q_{\max }$ in Table 7-1 should be multiplied by the TOC ratio [i.e., (TOC tank)/(TOC tank 101-SY)]. As discussed in Fox et al. (1993), the crust TOC values are probably about the same in both tanks 103-SY and 101-SY. However, there are some indications that towards the bottom of the tank, TOC values might be a factor of two larger in tank 103-SY. This was adopted for the previous study for tank 103-SY. Similarly, we will assume here the crust exothermic energy is bounded by a value which is a factor of two larger than tank 101-SY. It should be reemphasized that assuming the energetics in crust are double that in tank 101-SY has the effect of doubling the maximum selfheating temperature change observed in tank 101-SY waste sample adiabatic calorimetry.

The rate of chemical reaction is a separate but important concept that also needs to be addressed. If it is assumed the chemical reactions are proportional to the molecular collision frequency, this leads to the reaction rate being directly proportional to the TOC concentration. This is called a first order reaction. Doubling the TOC value should then mean that the heat generation rate would be doubled also. However, it is possible to have higher order reactions, such as a second order reaction where the rate would be increased four times (Hill 1977). The order of reaction for HEDTA, a major TOC contributor, has been evaluated for gas release in a simulated waste mixture, including high concentrations of nitrate and nitrite solution (Delegard 1980) and found to be represented by a first order reaction. While the temperature of the reactants and the reaction rates would be substantially different for a crust burn, there seems to be a sufficient basis to assume a first order reaction rate as the most likely and use this for our reference case. This is accomplished in the computer code by multiplying the TOC ratio, as defined earlier in this section, times $Q_{\text {gen }}$ in Table 7-1. A second order reaction was also examined, however, in the previous work (Fox et al. 1993).

A comparison of kinetics for the presumed crust with that from tank 101-SY is shown in Figure 7-1. Curves labeled 2 through 7 are the results of adiabatic calorimetry for waste samples from tank 101-SY. Curve 1 represents the conservative selection for the crust reactivity for these tanks, which is obtained by doubling both the exothermic energy and the temperature dependent reaction rates as discussed above.

A further comparison showing the effect of increasing the TOC is obtained by calorimetry simulation using our crust reaction code and is included in Table 7-2.

The TOC content is increased up to three times that of samples from tank 101-SY. The test time represents when all of the TOC has reacted during a calorimeter type test and is inversely proportional to the multiplier. It is the best indicator showing how the crust reaction rates become more rapid for a first order reaction when TOC values are increased. The maximum 
WHC-SD-WM-SAR-064, Rev. 0

Table 7-2. First Order Kinetics.

\begin{tabular}{|c|c|c|}
\hline $\begin{array}{c}\text { TOC } \\
\text { multiplier }\end{array}$ & $\begin{array}{c}\text { Maximum } \\
\text { temperature, } \\
{ }^{\circ} \mathrm{C}\end{array}$ & $\begin{array}{c}\text { Test time, } \\
\text { minutes }\end{array}$ \\
\hline 1 & 451 & 51 \\
\hline 2 & 650 & 22 \\
\hline 3 & 852 & 15.1 \\
\hline
\end{tabular}

temperature is also a function of the TOC but needs to be adjusted for the calorimeter baseline electrical heat input before this relationship becomes apparent.

It is also important to understand how the amount of reacted material is quantified in this report. As shown in Table 7-1, the self-heating energy for the most reactive sample is $4.6 \times 10^{8} \mathrm{~J} / \mathrm{m}^{3}$, which is equivalent to a reaction energy of $73 \mathrm{cal} / \mathrm{g}$. The heat generation rates, $Q_{\text {gen }}$, from Table 7-1 are integrated over time to compute the amount of chemical heat generated at each location. For example, if the amount of heat generated is $36.5 \mathrm{cal} / \mathrm{g}$, the crust material is said to be $50 \%$ reacted. To evaluate the total quantity of material that has reacted in the crust, the amount reacted at various depths is summed to provide the equivalent mass of crust material that is $100 \%$ reacted. If a TOC multiplier is used, these energy values should all be increased by the same multiplier.

At this point, the amount of conservatism being incorporated into the calculations should be emphasized. Crust from tank 103-SY probably has about the same TOC as crust from tank 101-SY. Yet, previous work doubled the measured crust exothermic energy and rates to ensure conservatism (Fox et al. 1993). However, as shown in Section 4.0, the DSS and DSSF in the AN and AW farms have a TOC that is about $1 / 5$ that of tank 101-SY. It should be reasonable to use reduced energies and rates corresponding to the lower TOC values. However, we have not performed any calorimetry for DSS or DSSF and additional margin may be needed until more data are acquired. Because of this, we continue to use the same crust model as used previously for tank 103-SY. This makes sure the crust energetics measured for these new tanks will be bounded by this hazard assessment. This ensures the present analysis and conclusions will remain applicable but leaves the expectation that calorimetry tests from these tanks will show much less reactive crust than measured for tank 101-SY.

\subsection{RESULTS OF CALCULATIONS}

This section presents computer simulations of plume burns in each tank. Previous sections have discussed and defined key parameters such as slurry gas composition, release rates, and total quantities. Also included were the crust TOC, chemical kinetics, and moisture. A conservative representation was developed using observed quantities or reasonable extrapolations from 
WHC-SD-WM-SAR-064, Rev. 0

tank 101-SY, which are selected as the best estimate cases. These results are discussed in detail before considering the conservative case, which is intended to bound all the tanks in this assessment.

\subsubsection{Best Estimate Cases}

The best estimate represents conservative choices of expected parameters and are listed in Table 7-3.

Table 7-3. Best Estimate Parameters.

\begin{tabular}{|l|c|}
\hline Slurry gas & Gas mixture fraction \\
\hline Hydrogen & 0.14385 \\
\hline Nitrous oxide & 0.12225 \\
\hline Ammonia & 0.05475 \\
\hline Methane & 0.00175 \\
\hline Carbon monoxide & 0.00125 \\
\hline Nitrogen & 0.16415 \\
\hline Water vapor & 0.01200 \\
\hline Air & \\
\hline Oxygen & 0.10500 \\
\hline Nitrogen & 0.39500 \\
\hline \hline Temperature, initial & $38{ }^{\circ} \mathrm{C}$ \\
\hline Pressure, initial & 1 atmosphere (atm) \\
\hline Burning time & 1 second \\
\hline TOC multiple of tank 101-SY & 2 \\
\hline Order of chemical reaction & 1 st \\
\hline Gas plume shape & Sphere \\
\hline Crust moisture & $10 \%$ \\
\hline
\end{tabular}

The gas releases described in Section 4.3 are diluted with an equal volume of air (100\% dilution) which results in the concentrations shown in Table 7-3. This dilution considers the turbulent mixing processes (discussed in Section 5.0) as the gas moves from the waste surface toward the top of the tank dome where an ignition source could be present. Actual dilutions are expected to be more because of the sporadic character of gas releases but the $100 \%$ dilution has been shown to be a defendable lower bound (Fox et al. 1993). 
The burning time of 1 second is based on approximate burning velocities and, as indicated by the parametrics performed earlier (Fox et al. 1993), is not a sensitive item.

Based on the experience from tank 101-SY (Fox et a1. 1992), the crust moisture content is set at the conservative value of $10 \%$. Floating crust has been measured to have values much greater, e.g., 15 to $40 \%$. Even very dried samples from the sludge weight sampler show $10 \%$ moisture. There may be small areas where a waste deposits and crust have been separated from the liquid and are drier. These areas include a "bath tub ring" on the tank sidewall or clumps attached to tank internals, both of which were observed in tank 101-SY.

The moisture content of this waste has not been measured so will be assumed to be dry. Evaluation of margins between these conditions and a propagating reaction will use dry crust.

The results of the best estimate burning calculations for each tank are shown in Table 7-4. The results are discussed using tank 101-AW as an example.

Table 7-4. Peak Values for Plume Burning with Best Estimate Conditions (100\% Air Added, $10 \%$ Crust Moisture).

\begin{tabular}{|l|c|c|c|c|c|c|c|}
\hline Tank ID & $\begin{array}{c}\text { Slurry } \\
\text { gas } \\
\text { release } \\
\left(\mathrm{ft}^{3}\right)\end{array}$ & $\begin{array}{c}\text { Gas } \\
\text { temp } \\
\left({ }^{\circ} \mathrm{C}\right)\end{array}$ & $\begin{array}{c}\text { Pressure } \\
(\text { atm abs })\end{array}$ & $\begin{array}{c}\text { Total } \\
\text { heat } \\
\text { transfer } \\
\left(\mathrm{J} / \mathrm{m}^{2}\right)\end{array}$ & $\begin{array}{c}\text { Crust } \\
\text { surface } \\
\text { temp } \\
\left({ }^{\circ} \mathrm{C}\right)\end{array}$ & $\begin{array}{c}\text { Surface } \\
\text { reacted } \\
\text { exotherm } \\
(\%)\end{array}$ & $\begin{array}{c}\text { Chemical } \\
\text { heat } \\
\text { produced } \\
\left(\mathrm{J} / \mathrm{m}^{2}\right)\end{array}$ \\
\hline 101 -AW & 1,576 & 1690 & 1.576 & $1,037,600$ & 267 & 0.49 & 2,410 \\
\hline 103 -AN & 2,231 & 1691 & 1.510 & $1,121,600$ & 278 & 0.60 & 2,985 \\
\hline $104-A N$ & 3,287 & 1765 & 1.990 & $1,424,400$ & 360 & 1.20 & 6,507 \\
\hline $105-A N$ & 2,185 & 1733 & 1.808 & $1,208,900$ & 302 & 0.72 & 3,827 \\
\hline $103-S Y$ & 1,535 & 1638 & 1.245 & 923,400 & 233 & 0.31 & 1,672 \\
\hline $103-S Y *$ & 1,663 & 1951 & 1.321 & $1,192,000$ & 361 & 0.81 & 4,119 \\
\hline \multicolumn{7}{|c|}{ Conservative maximum burn conditions } \\
\hline CEMAXBRN & 4,000 & 2174 & 2.88 & $2,245,000$ & 1004 & 100 & 683,700 \\
\hline
\end{tabular}

*Conservative gas composition.

The slurry gas release defined in Table 4-3 is mixed with an equal volume of air and burned creating a peak temperature and pressure of $1690{ }^{\circ} \mathrm{C}$ and $1.576 \mathrm{~atm}_{2}(\mathrm{abs})$, respectively. The peak pressure corresponds to $8.5 \mathrm{lb} / \mathrm{in}^{2}$ (gage). This pressure is substantially smaller than the conservative values calculated in Section 8.1 (12 psig) because of heat losses during the 1 second plume burn and not being a worst case mixture with air. 
The total heat transferred to the crust during the 50-second calculated interval is about $10^{6} \mathrm{~J} / \mathrm{m}^{2}$. The surface temperature reaches a maximum of $267{ }^{\circ} \mathrm{C}$ at 2.14 seconds and then cools because of conduction into the deeper crust. The heat transfer numerics require a fine nodal structure near the surface because of the rapidity of the heat pulse. Node spacings of $0.125 \mathrm{~mm}$ are used near the surface with larger spacings deeper in the interior.

Temperatures for four nodal positions are shown in Figure 7-2. While the calculations were carried out for a time period of 50 seconds, only the first 10 seconds are shown here as being the most significant.

The chemical reactions in the crust are significantly affected by the temperature attained during the transient. Figure 7-2 shows the surface temperature reaches about $38{ }^{\circ} \mathrm{C}$ higher than the second node. This causes a difference in the crust reaction as shown in Figure 7-3. This shows the fraction of maximum exothermic energy, which is released. Alternatively, it can be viewed as the fraction of TOC, which has reacted at that location. In any event, the surface releases about $0.49 \%$ of its energy while the next node, at $0.125 \mathrm{~mm}$, releases about $0.35 \%$ before cooling suppresses the reactions. (These chemical reaction values are about $0.1 \%$ higher than those shown in Figure 7-3 because the reaction has not yet stopped at 10 seconds.) Note the fourth node at $0.76 \mathrm{~mm}$ has no significant chemical reactions. The heat generated by the exothermic reaction is about $2,410 \mathrm{~J} / \mathrm{m}^{2}$ and amounts to about $0.23 \%$ of the heat which has crossed the surface from the gas plume. The heat generated by crust reactions is a small contributor to the temperatures attained.

The effective radiation heat transfer coefficient, as defined by Equation 6-4, is calculated and plotted in Figure 7-4. It is much larger than the convective heat transfer coefficient. For this reason, it is possible to ignore the effects of sharp edges and protuberances which might cause high localized convective heat transfer.

Results for the other tanks vary somewhat because of the size of gas release and the volume of air in the dome space, but the conclusions are essentially the same. Burning the best estimate gas composition and release size produces very slight crust reactions.

\subsubsection{Parametric Studies}

Previous studies (Fox et a1. 1993) performed a series of parametric cases which tested the sensitivity of the calculated results to various parameters such as TOC content, plume burning time, gas release quantity, reaction order, moisture content, dilution with air, and plume shape. These did not show anomalous findings, which would modify the conclusions that a propagating reaction would not occur, even if the crust were dry. Since the reference parametric case used in that study was based on tank 103-SY and the other flammable gas tanks are similar, these results can be applied to this new study also. 
WHC-SD-WM-SAR-064 ReV. O

Figure 7-2. Temperature Histories for Tank 101-AW.

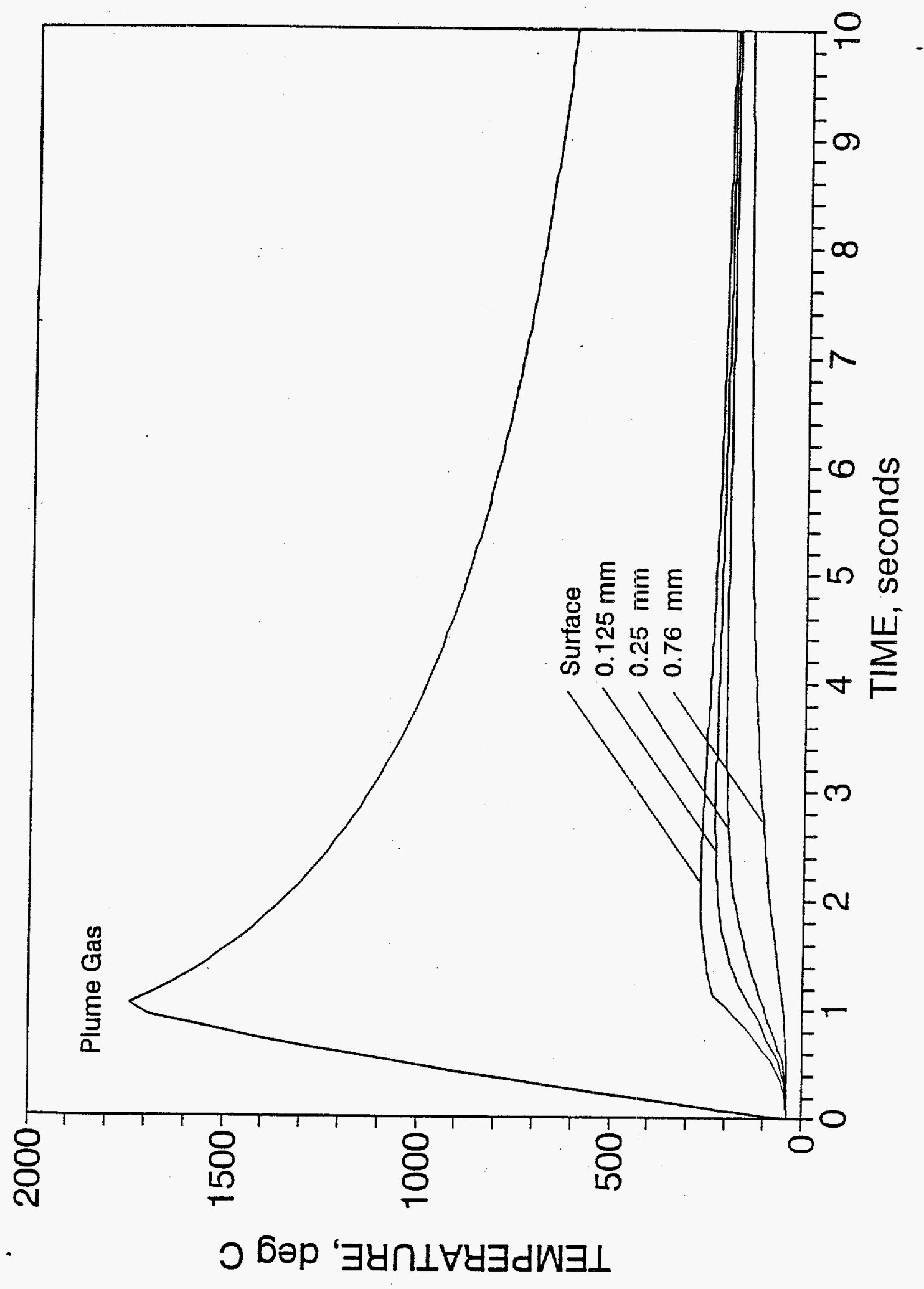


WHC-SD-WM-SAR-064 REV.O

Figure 7-3. Crust Exothermic Reactions.

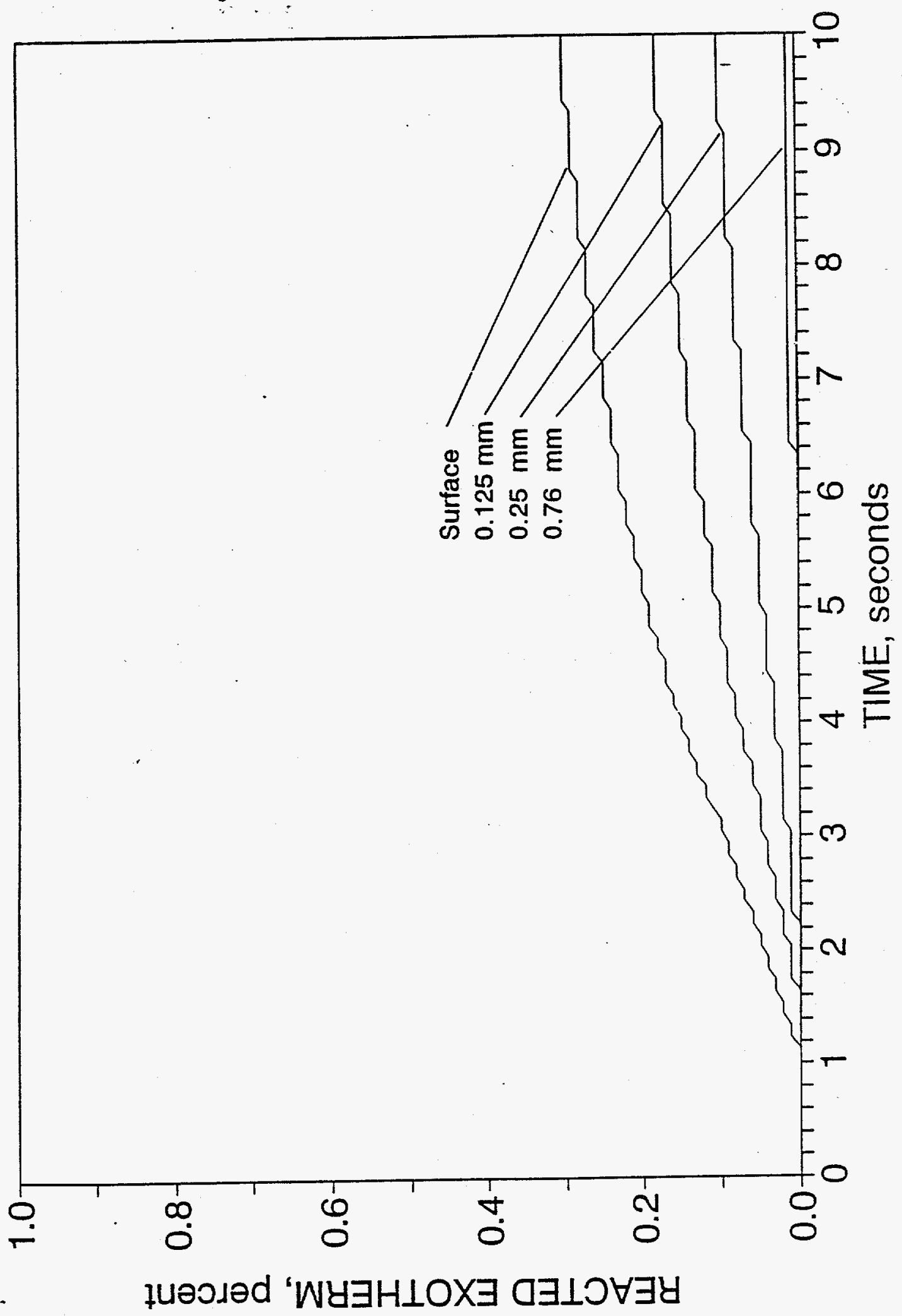


WHC-SD-WM-SAR-064 ReV.O

Figure 7-4. Thermal Radiation Coefficient (Tank 101-AW).

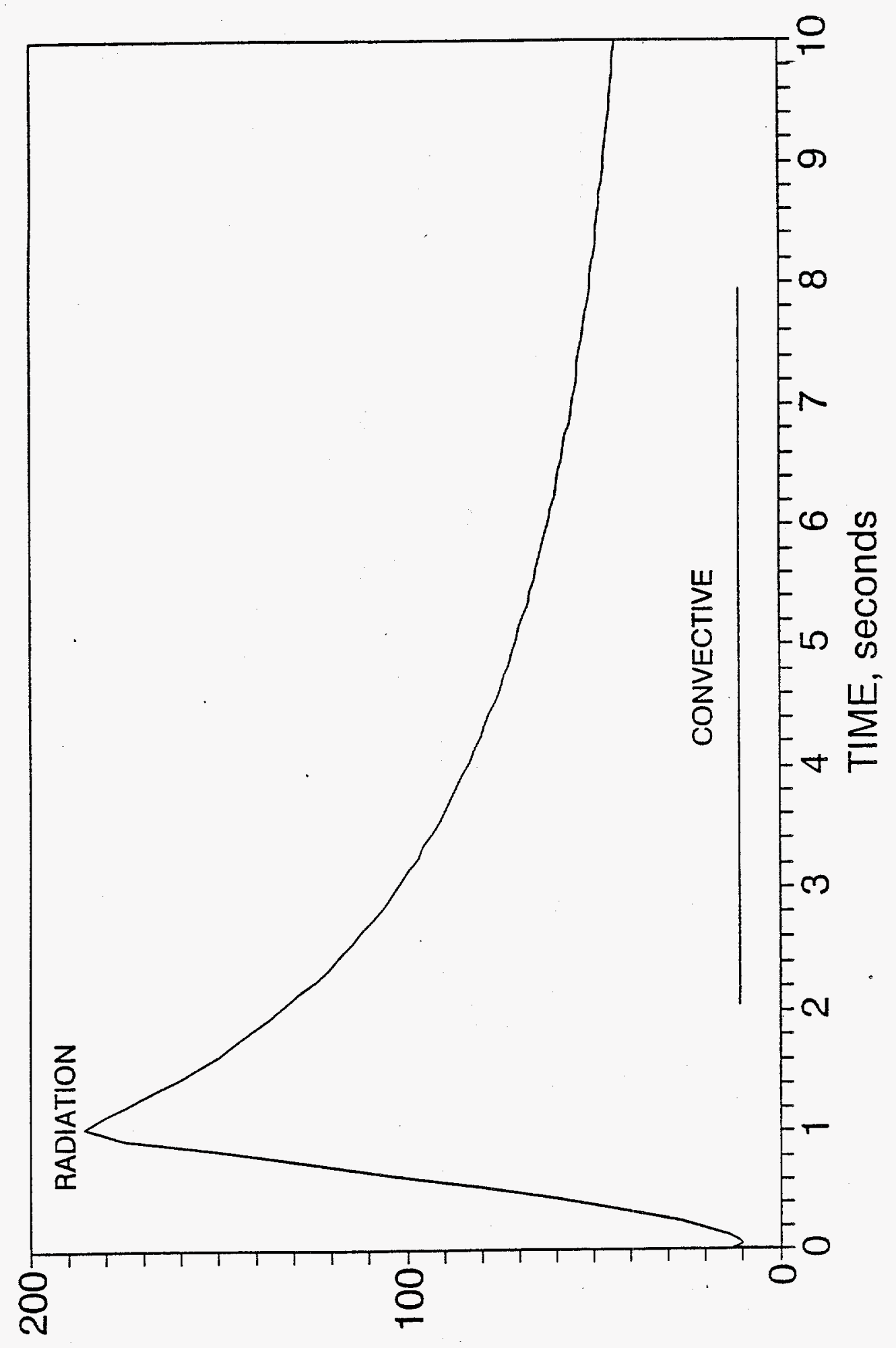

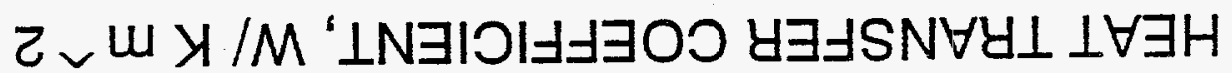




\subsubsection{Results of Conservative Calculations}

Conservative results, also included in Table 7-4, show two examples pertinent to this report. Both use a conservative gas mixture which increases the concentration of ammonia and, as a result, the heat of combustion. The first example reconsiders tank 103-SY. The second example selects a maximum burn condition which bounds gas composition, the minimum size dome space, and a bounding slurry gas release. The purpose is to select the worst of al1 parameters to obtain a bounding tank loading for the flammable gas tanks and use these conditions to evaluate a radioactive source term for the dose calculations.

7.2.3.1 Tank 103-SY. Tank 103-SY is included in this study for two reasons. First, we wish to update the simplified gas composition used previously (Fox et al. 1993) to the new gas composition used in this report, which includes ammonia. Second, we wish to connect the previous detailed study and the parametrics performed with the present study.

Table 7-4 shows results for tank 103-SY, both best estimate and Conservative gas compositions. The crust reactions are the most indicative, showing the severity of the heat loading. The maximum crust surface temperature is calculated to be 233 and $361{ }^{\circ} \mathrm{C}$ while the surface material only reacted 0.31 and $0.81 \%$ of the available exothermic energy, respectively. The previous study, which used a simplified gas composition, produced surface temperatures of 242 to $288^{\circ} \mathrm{C}$ and the surface reactions were 0.28 and $0.57 \%$ for the reference and evaluation conditions, respectively. These results are very comparable with the present study and lead to similar conclusions, a) though the effect of the ammonia is evident by the more severe crust heating.

7.2.3.2 Conservative Maximum Burn Conditions. The conservative maximum burn conditions shown in Table 7-4 are substantially more severe than any of the best estimate loadings. The larger gas quantity in the minimum dome volume produces gage pressure loadings that are about double. Similar results are observed for the heat transfer process. The surface temperature peaks at $1004{ }^{\circ} \mathrm{C}$ while the surface material is completely chemically reacted. The chemical heat produced adds about 30\% to the heat transferred from the heated plume. The completely reacted layer extends beyond $0.25 \mathrm{~mm}$ but is on $7 y 3 \%$ reacted at $1.3 \mathrm{~mm}$. Thus, the thickness of the layer which has chemical reactions is limited to 2 to $3 \mathrm{~mm}$ if directly beneath the plume and even less as the radial distance is increased from the plume centerline. Still, no propagating reaction develops and the reactions are 1 imited to this thin 1ayer.

\subsubsection{Evaluation of Margins}

The calculations shown previously demonstrate that neither the best estimate nor the conservative estimate quantities of gas, when burned as a plume, lead to a propagating reaction in the crust material. However, the question arises as to how much margin 1 ies between the conservative estimate case and the point where a propagating reaction could occur. This section quantifies that question. 
The same plume burn computer model described in Section 6.0 is applied here. Previous work considered the crust exothermic reactions to be first order. So both the energy release and rates are assumed directly proportional to the TOC content (i.e., doubling the TOC beyond tank 101-SY values would double the energy release and the reaction rates). However, for this work we will decouple the energy and rates so as to examine the importance of each quantity. A modified version of the computer code was created to obtain results with these input quantities separated. Both the energy and reaction rates are applied as multiples of values obtained for tank 101-SY waste. The calculation procedure consists of selecting a reaction rate and rerunning the code many times while increasing the crust energy until the reaction begins to propagate. The reaction rate ratio, $R / R_{0}$, was varied from 0.2 to 10 with the results shown in Figure 7-5. The energy ratio obtained, $E / E_{0}$, was never less than 2.2 and increased for slower rates, as would be expected. For the reference reaction rate ratio of 2 , used in this report, the crust reactions

- propagated if energy ratios were greater than 2.75. This provides almost $40 \%$ margin beyond the reference case and 175\% margin beyond tank 101-SY results. Note these margins do not include the effect of crust moisture, which would result in even larger margins. This demonstrates the conservatism remaining in these calculations and emphasizes that a propagating reaction in the crust will not be ignited by burning a combustible plume. 

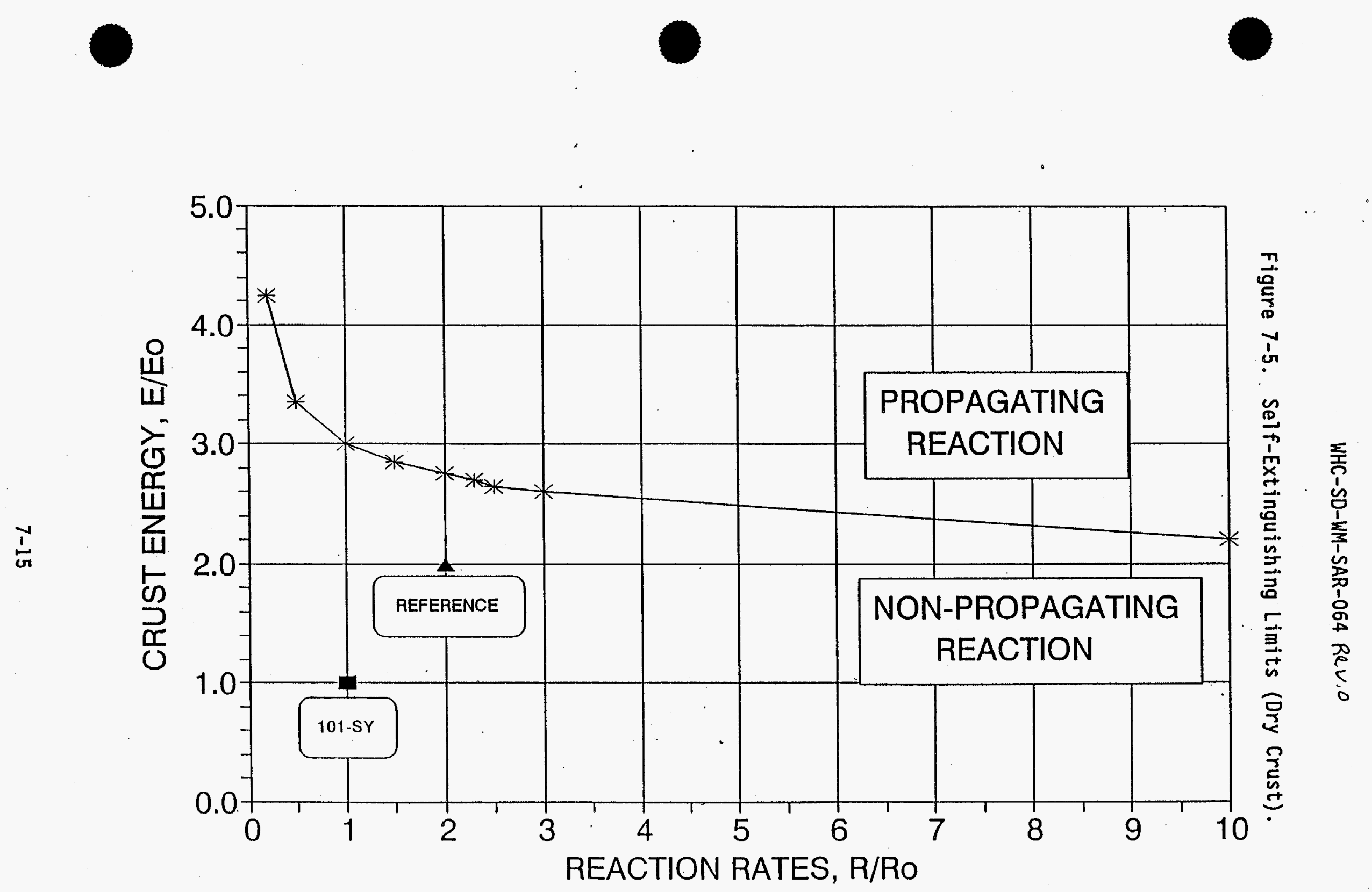
WHC-SD-WM-SAR-064, Rev. 0

This page intentionally left blank.

$7-16$ 


\subsection{CONSEQUENCES OF SLURRY GAS BURN EVENTS}

This section provides the tank pressures resulting from postulated slurry gas burns. The radiological source terms are developed and dose consequences provided. Risk associated with these tanks is shown to be well within the risk acceptance guidelines.

\subsection{TANK STRUCTURAL REACTIONS}

The pressure created in the dome space when siurry gas is released and ignited was calculated from the thermodynamic models described earlier. During the burning, the slurry gas could exist as a plume or be completely mixed. For large releases, it is assumed the slurry gas will be mixed with all the air in the dome space. However, as the quantity of slurry gas is parametrically decreased, at some point the LFL will be reached and completely mixed combustion is not possible. For these quantities of slurry gas and smaller, a plume is assumed to exist and be mixed with enough air to maximize the pressures predicted.

There are two additional assumptions incorporated which make the calculations conservative. First, no venting through the ventilation system or risers is permitted during the burning event. Second, no heat transfer is considered from the hot gases to the air in the dome space or to the dome boundaries. More realistic calculations which include heat transfer show peak pressure reduction by as much as 25 to $30 \%$.

The range for this parametric study includes slurry gas releases of 1,000 to $6,000 \mathrm{ft}^{3}$ into dome space volumes of 35,000 to $85,000 \mathrm{ft}^{3}$. Air is assumed to vent during the release process so the pressure is at $1 \mathrm{~atm}$ at the time of ignition. Both the best estimate and conservative gas compositions are used in the burn pressure calculations and the results are shown in Figures 8-1 and 8-2. The dome sizes used for these parametric cases are selected to correspond to the tanks included in this assessment. Free volume for the different tanks is noted on the figures. The transition from completely mixed to plume burn calculations is also noted on the figures. Peak slurry gas burn pressures are summarized in Table 8-1.

Table 8-1. S7urry Gas Burn Pressures.

\begin{tabular}{|c|c|c|c|}
\hline Tank & Free volume, $\mathrm{ft}^{3}$ & $\begin{array}{c}\text { Best estimate, } \\
\text { psig }\end{array}$ & $\begin{array}{c}\text { Conservative } \\
\text { bounding, psig }\end{array}$ \\
\hline $103-\mathrm{SY}$ & 87,609 & 5 & 7 \\
\hline $101-\mathrm{AW}$ & 37,634 & 12 & 17 \\
\hline $103-\mathrm{AN}$ & 61,100 & 10 & 14 \\
\hline $104-\mathrm{AN}$ & 46,010 & 20 & 28 \\
\hline $105-\mathrm{AN}$ & 37,360 & 13 & 17 \\
\hline
\end{tabular}


WHC-SD-WM-SAR-064, Rev。 0

Figure 8-1. Slurry Gas Burn Pressures for Best Estimate Cases.

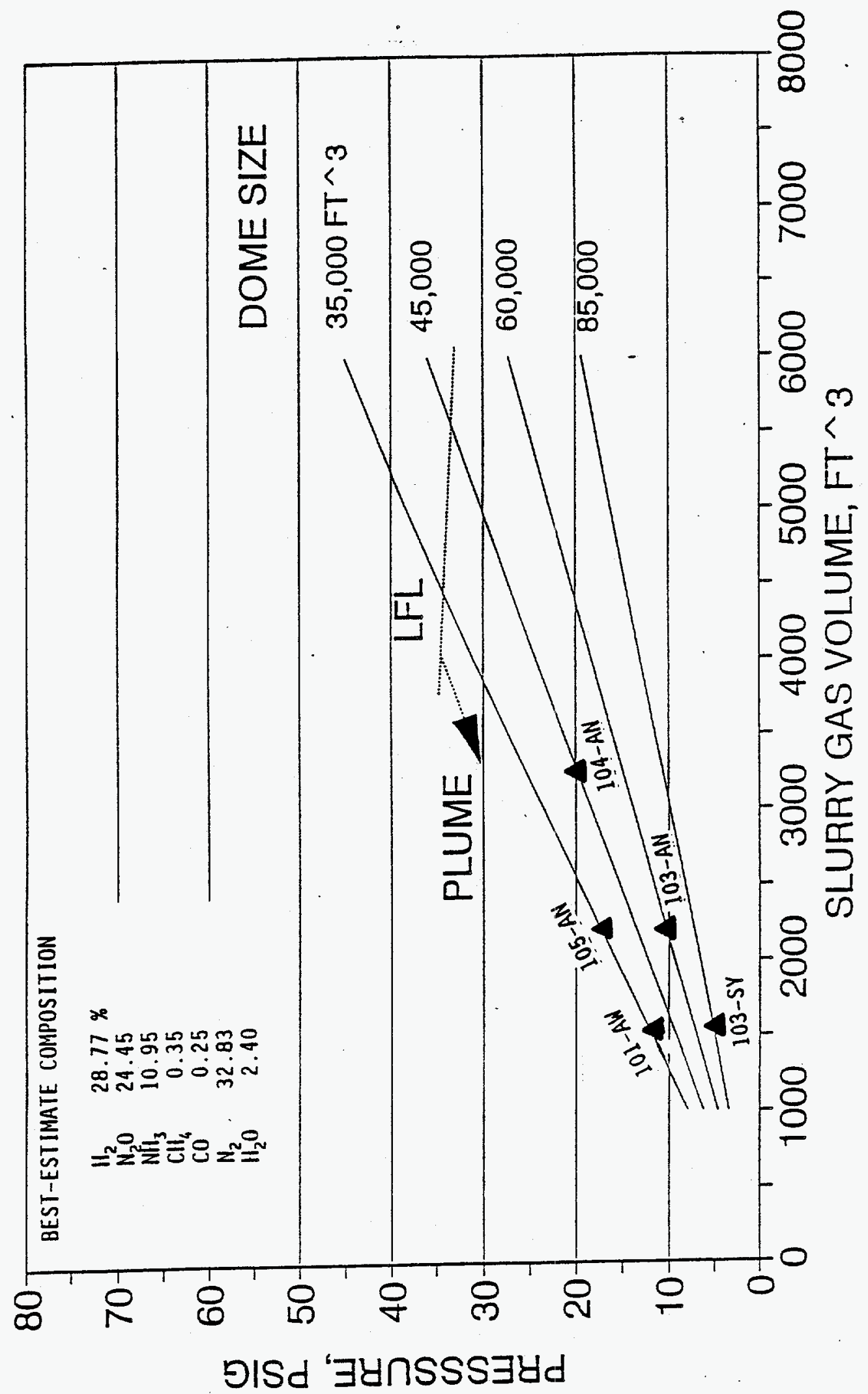


WHC-SD-WM-SAR-064, Rev. 0

Figure 8-2. Slurry Gas Burn Pressures for Conservative Cases.

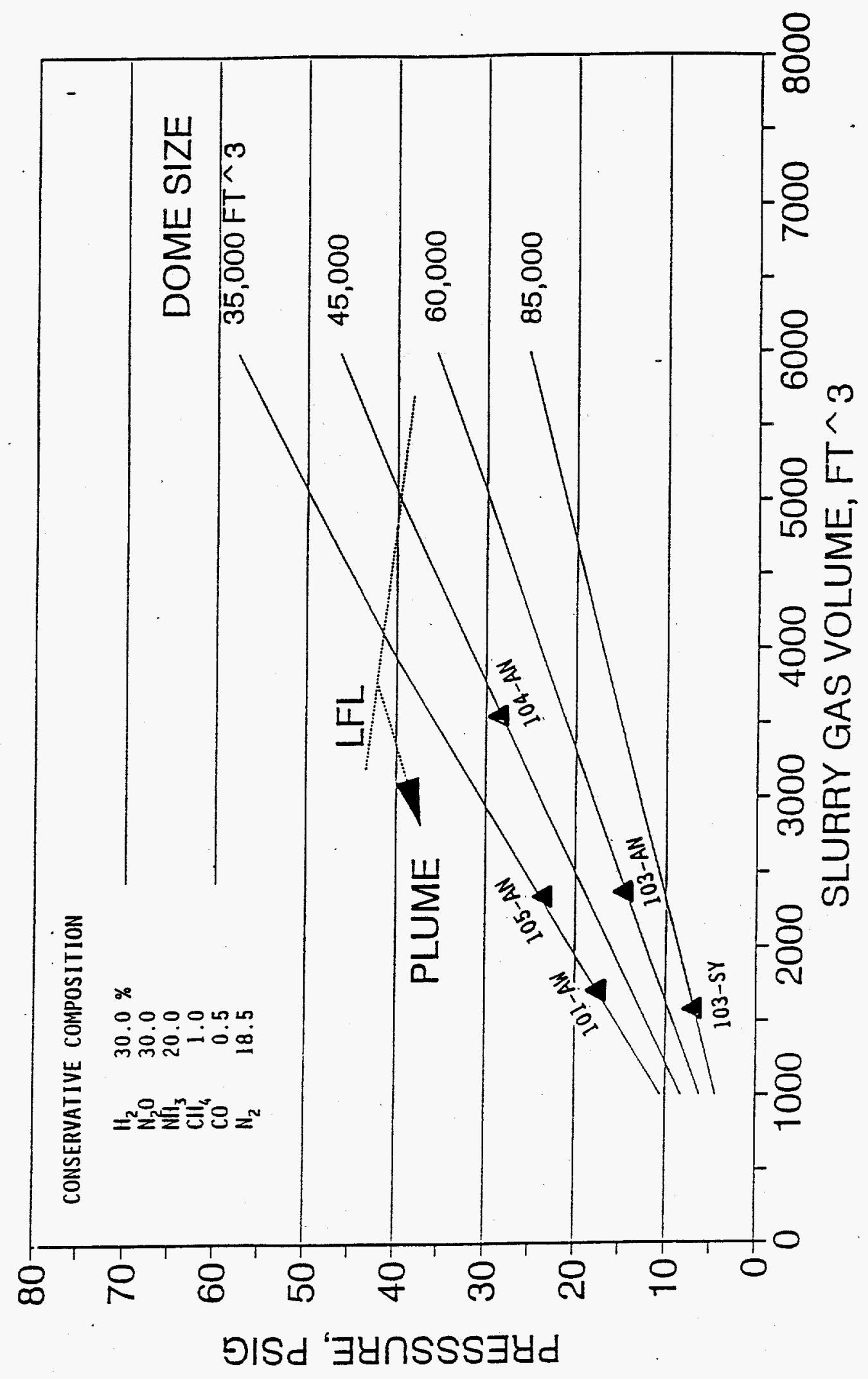


WHC-SD-WM-SAR-064, Rev。 0

The structural capability of this set of tanks was evaluated in Julyk (1994), and the assessment is included as Appendix D. This assessment concludes that the existing analyses determining the pressure capability of tank 101-SY are directly applicable to tanks AN-101, AN-103, -104, and -105 . A similar determination had previously been made for 103-SY (Fox et al. 1993). All of these tanks are of similar structural design to the extent that the 101-SY pressure capability can be considered as a lower bound to the pressure capability of AW-101, AN-103, -104, and -105. These tanks all share the same limiting local discontinuity, a 4-in. riser penetrating the $3 / 8 \mathrm{in}$. to $1 / 2 \mathrm{in}$. plate thickness transition in the dome liner. The stress analysis results are summarized in Figure 8-3 in Julyk (1992, as presented in Simpson et al. [1993], Appendix 5C). Figure 8-3 indicates that initial cracking at the 4-in. riser discontinuity is predicted at 66 psig. If the local ductility is taken as one-half the base metal strain limit (a typical American Society of Mechanical Engineers allowance for less ductile weld metal) cracking.is calculated at $60 \mathrm{psig.} \mathrm{At} \mathrm{these} \mathrm{pressure} \mathrm{levels,} \mathrm{large} \mathrm{margins} \mathrm{to} \mathrm{failure}$ remain at the other discontinuities. Based on this analysis, loss of tank integrity is not predicted below at least 60 psig, static pressure.

Effects of dynamic pressure loads on the static pressure limits developed on Figure 8-3 have been considered by $C$. J. Moore and are provided as Appendix $E$ of this report. For slurry gas volumes in the range applicable to this set of tanks, and burn times of 0.01 and 1 second, the ratio of static failure pressure to peak burn pressure was found to range from 0.97 to 1.13 . For conservatism, 0.9 is used in this report. Thus, the tank failure pressure becomes approximately $55 \mathrm{psig}$ when the dynamic loading correction is applied to the 60 psig limit discussed earlier.

\subsection{RADIOLOGICAL SOURCE TERMS}

The generation and release of radioactive aerosols for the postulated burn cases were calculated with the methods used for tank 101-SY (McCormack 1992, as presented in Simpson et al. 1993). Two burns in the tank dome space were considered, the best estimate case and the conservative bounding case. The aerosol release has been estimated as the sum of two types of release called "thermal" and "mechanical." The thermal release results from heated crust which undergoes chemical reactions and generates combustion product gases and water vapor which become saturated with crust isotopes. The mechanical release sources include resuspension from tank surfaces, crust depressurization, and aerodynamic entrainment from heated crust. The results of the thermal release will be discussed first.

\subsubsection{Thermal Release}

The method used to determine the thermal release as a function of the crust temperature is to assume that the gases are saturated with the isotope compounds of interest contained in the crust. That is, the gas and vapor leaving the heated crust contain volume fractions of volatile isotopic compounds in accordance with their vapor pressures at crust temperatures. The quantity of released material can then be summed for the affected mass and temperature zones in the heated crust to find the total release to the tank head space. The details of the calculations are given in Appendix $C$. 
WHC-SD-WM-SAR-064, Rev. 0

Figure 8-3. Dome Local Discontinuities Principal Strain vs. Static Pressure.

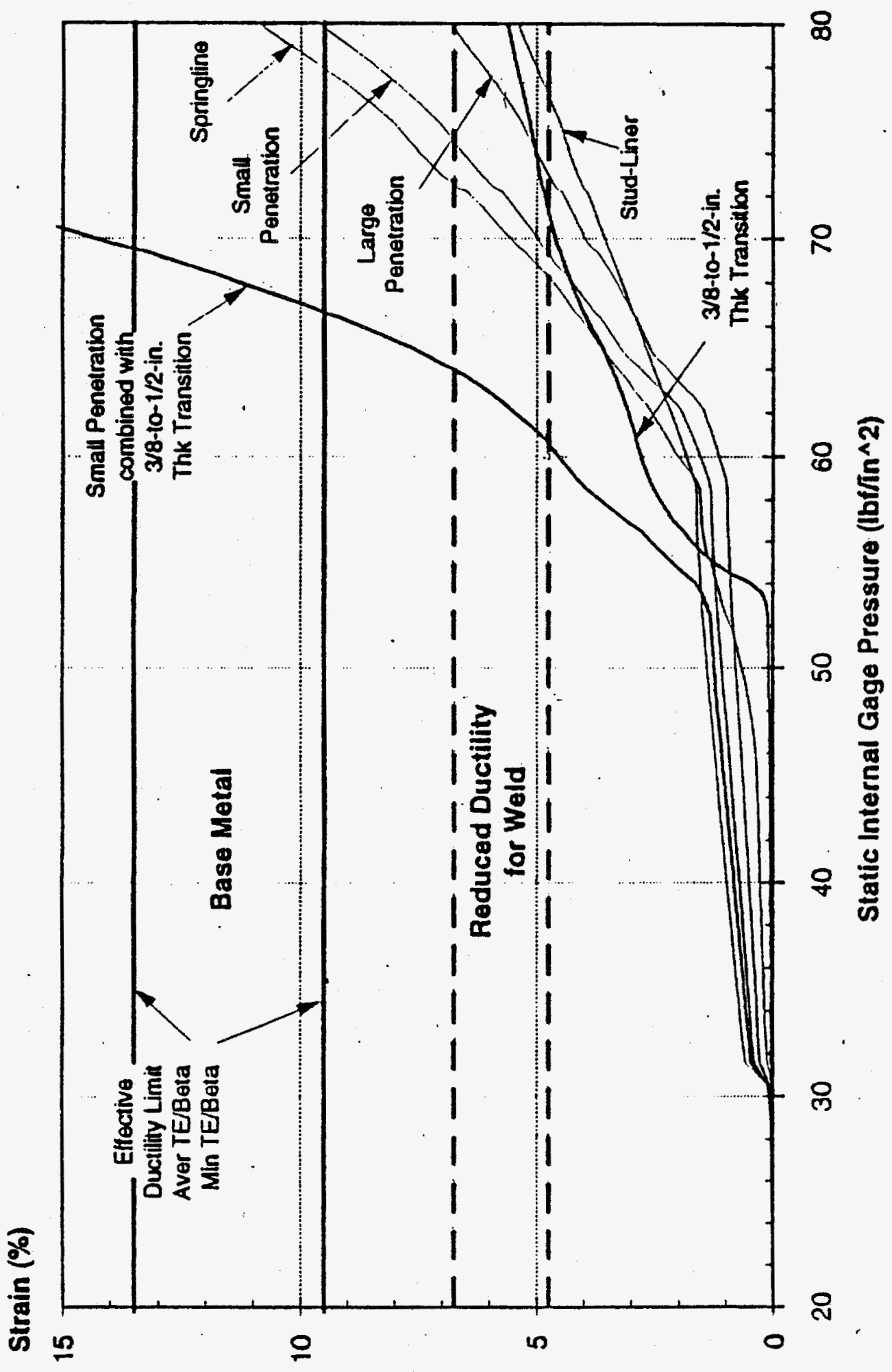


Transient maximum crust temperatures resulting from the plume burn are shown in Table 8-2. The crust surface was divided into 1 -m-wide radial nodes radiating outward from the vertical centerline of the flammable gas plume. The mass at risk is the mass of crust that becomes dried out as a result of the $\mathrm{flammable} \mathrm{gas} \mathrm{burn.} \mathrm{It} \mathrm{represents} \mathrm{the} \mathrm{mass} \mathrm{of} \mathrm{crust} \mathrm{heated} \mathrm{to} \mathrm{the} \mathrm{point}$ where the temperature reaches $266^{\circ} \mathrm{F}\left(130^{\circ} \mathrm{C}\right)$, the boiling point of a saturated solution of sodium nitrate in water. The mass at risk is used to calculate the volume of water generated in each depth increment. That volume is assumed to become saturated with the volatile fission product vapor at the corresponding crust temperature. The mass at risk will also be used later to estimate the "mechanical" release. The volume of the gaseous combustion products would also normally be assumed to become saturated in the volatile fission product vapor. For these cases, the gaseous reaction product volume is negligible compared to the water vapor volume, as shown in Appendix C.

Table 8-2. Maximum Crust Temperatures.

\begin{tabular}{|c|c|c|c|c|}
\hline $\begin{array}{c}\text { Distance from } \\
\text { centerline } \\
(\mathrm{m})\end{array}$ & \multicolumn{2}{|c|}{ Best estimate case } & \multicolumn{2}{c|}{ Conservative bounding } \\
\cline { 2 - 5 } & $\begin{array}{c}\text { Temperature } \\
\left({ }^{\circ} \mathrm{F}\right)\end{array}$ & $\begin{array}{c}\text { Mass at risk } \\
(\mathrm{kg})\end{array}$ & $\begin{array}{c}\text { Temperature } \\
\left({ }^{\circ} \mathrm{F}\right)\end{array}$ & $\begin{array}{c}\text { Mass at risk } \\
(\mathrm{kg})\end{array}$ \\
\hline 0.5 & 671 & 10.1 & 1860 & 22.1 \\
\hline 1.5 & 606 & 27.3 & 1342 & 61.6 \\
\hline 2.5 & 514 & 36.6 & 982 & 65.0 \\
\hline 3.5 & 429 & 35.7 & 762 & 75.4 \\
\hline 4.5 & 369 & 32.3 & 569 & 66.5 \\
\hline 5.5 & 323 & 21.7 & 455 & 65.8 \\
\hline 6.5 & 289 & 9.5 & 385 & 77.8 \\
\hline 7.5 & 263 & 0 & 338 & 40.5 \\
\hline 8.5 & 243 & & 304 & 18.4 \\
\hline 9.5 & 227 & & 279 & 7.0 \\
\hline 10.5 & 214 & & 259 & 0 \\
\hline
\end{tabular}

\subsubsection{Mechanical Release}

The mechanical release fraction was determined by multiplying the mass at risk by the same release fractions used in evaluating the tank 101-SY $2,500 \mathrm{ft}^{3}$ and 4,000 $\mathrm{ft}^{3}$ hydrogen burns (McCormack 1993, as presented in simpson et al. 1993). The release fractions used, along with the mass at risk, are shown in Table 8-3. The mass at risk is the mass of crust dried out 
by the plume burn (Table 8-2). The crust resuspension release fractions are based on work reported in Fox et al., Section 7.0 (1990). Two components are involved. One is based on resuspension of dried $\mathrm{PuNO}_{3}$ particulates into a moving air stream. Mishima et a1. (1968) determined a release fraction of 3E-4 for that process. A second component of the crust resuspension results from dome depressurization as the burn overpressure blows down to the atmosphere. Expansion of the gas forced into crust surface interstices could be expected to levitate particulates when it re-expands. This effect was estimated by the use of tests conducted by Ballinger et a1. (1987) that measured resuspension of depleted uranium dioxide powder. Millisecond depressurizations of containers of the powder from test pressures of 9 to $25 \mathrm{lb} / \mathrm{ft}^{2}$ resulted in resuspension factors that averaged $5 \mathrm{E}-4$. The rapidiy dried crust in the postulated burn is expected to be somewhat cohesive in contrast to the loose particles in the test, and therefore use of this release factor is considered conservative. The foregoing two release factors have been combined and rounded upward to $1 \mathrm{E}-03$.

Table 8-3. Mechanical Release Components.

\begin{tabular}{|l|c|c|}
\hline \multirow{2}{*}{ Release mechanism } & \multicolumn{2}{|c|}{ Burn case } \\
\cline { 2 - 3 } & Best estimate & Conservative bound \\
\hline Crust resuspension & $1 \mathrm{E}-3$ & $1 \mathrm{E}-3$ \\
\hline Dried crust mass & $173.2 \mathrm{~kg}$ & $500 \mathrm{~kg}$ \\
\hline Crust aerosol & $173.2 \mathrm{~g}$ & $500 \mathrm{~g}$ \\
\hline Resuspension from tank surface & $10 \mathrm{~g}$ & $100 \mathrm{~g}$ \\
\hline Total aerosol generated & $183.2 \mathrm{~g}$ & $600 \mathrm{~g}$ \\
\hline
\end{tabular}

An additional mechanical release term in Fox et al. (1990) was used to account for the dust formation expected from the rapid expansion and contraction of the tank dome by the pressure transient. Significant plastic deformation of the ductile steel could.occur as limit pressures are reached (Julyk 1992). Consistent with the earlier work (Fox et al. 1990, Sections 7.2.1 and 7.1.1.3), it was assumed that the equivalent of $100 \mathrm{~g}$ of crust would be released from the tank dome surfaces for the conservative case and $10 \mathrm{~g}$ for the best estimate case. These mechanical release quantities are summarized in Table 8-3. The dried crust mass is from the spreadsheet in Appendix $C$ and the crust aerosol generated is obtained from the resuspension factor.

The source terms for the two burn cases are given in Tables 8-4 and 8-5 for the best estimate and conservative bounding cases, respectively. Crust concentration of radionuclides was developed in Section 3.0 . 


\subsubsection{Isotopic Releases from the Primary Exhaust System}

Tank pressurization in excess of 1 or $2 \mathrm{psig}$ is expected to cause rupture of HEPA filters in the tank ventilation system. Consistent with prior dose assessments, it is assumed that $10 \%$ of the radioactive inventory in the exhaust system will become suspended in the tank blowdown gases and be released to the environs as respirable particulate material. Dose rate survey measurements made on the external surfaces of the ducts, in-line demister, and HEPA filter housings served as a basis for estimating the contained inventory (Himes 1992, as presented in Simpson et al. (1993), Appendix B). This information was converted to a source term that assumed that the exhaust accumulation had the same isotopic composition as the tank surface crust. With the $10 \%$ release assumption, the source term contribution from the ventilation system is shown in Table 8-6.

\subsection{RADIOLOGICAL DOSE CONSEQUENCES}

\subsubsection{Results}

The radiological dose consequences are given in Tables $8-7,8-8$, and 8-9 for the ventilation system release, the best estimate, and conservative flammable gas burns, respectively. The latter two tables include the contribution from ventilation system failure. The results were obtained with the GENII code (Napier et al. 1988) using dispersion factors generated by the GXQ code (Hey 1993). This results in the use of 99.5 percentile worst case meteorology onsite and 95 percentile offsite. The 100-m location is the current standard for the onsite receptor. The worst case offsite receptor is at the site boundary $15.9 \mathrm{~km}$ east of the AN tank farm.

Table 8-4. Source Term - Best Estimate.

\begin{tabular}{|c|c|c|c|c|c|}
\hline \multirow{2}{*}{ Isotope } & \multirow{2}{*}{$\begin{array}{c}\text { Crust } \\
\text { concentration } \\
(\mu \mathrm{C} i / \mathrm{g})\end{array}$} & \multirow{2}{*}{$\begin{array}{c}\text { Thermal } \\
\text { release } \\
(\mu \mathrm{C} i)\end{array}$} & \multicolumn{2}{|c|}{$\begin{array}{c}\text { Mechanical release } \\
(\mu \mathrm{C} i)\end{array}$} & \multirow{2}{*}{$\begin{array}{c}\text { Total } \\
\text { release } \\
(\mu \mathrm{C} i)\end{array}$} \\
\cline { 4 - 6 } & $\mathrm{Sr}-90$ & & $\begin{array}{c}\text { Crust } \\
\text { release }\end{array}$ & $\begin{array}{c}\text { Surface } \\
\text { deposits }\end{array}$ & \\
\hline $\mathrm{Tc}-99$ & 41 & $1.5 \times 10^{3}$ & $6.2 \times 10^{1}$ & 3.6 & $1.6 \times 10^{3}$ \\
\hline $\mathrm{I}-129$ & 0.36 & $2.3 \times 10^{-3}$ & $6.1 \times 10^{1}$ & 3.5 & $6.5 \times 10^{1}$ \\
\hline $\mathrm{Cs}-137$ & 1200 & $1.5 \times 10^{5}$ & $2.1 \times 10^{5}$ & $1.2 \times 10^{4}$ & $3.7 \times 10^{5}$ \\
\hline $\mathrm{Np}-137$ & $<0.61$ & & $1.1 \times 10^{2}$ & 6.1 & $1.2 \times 10^{2}$ \\
\hline $\mathrm{Pu}-239$ & 0.093 & & $1.6 \times 10^{1}$ & 0.9 & $1.7 \times 10^{1}$ \\
\hline $\mathrm{Am}-241$ & 1.4 & & $2.4 \times 10^{2}$ & $1.4 \times 10^{1}$ & $2.5 \times 10^{2}$ \\
\hline
\end{tabular}


WHC-SD-WM-SAR-064, Rev. 0

Table 8-5. Source Term - Conservative.

\begin{tabular}{|c|c|c|c|c|c|}
\hline \multirow{2}{*}{ Isotope } & \multirow{2}{*}{$\begin{array}{c}\text { Crust } \\
\text { concentration } \\
(\mu \mathrm{Ci} / \mathrm{g})\end{array}$} & \multirow{2}{*}{$\begin{array}{l}\text { Thermal } \\
\text { release } \\
(\mu \mathrm{Ci})\end{array}$} & \multicolumn{2}{|c|}{ Mechanical release ( $\mu \mathrm{C} i)$} & \multirow{2}{*}{$\begin{array}{l}\text { Total } \\
\text { release } \\
(\mu \mathrm{Ci})\end{array}$} \\
\hline & & & $\begin{array}{l}\text { Crust } \\
\text { release }\end{array}$ & $\begin{array}{l}\text { Surface } \\
\text { deposits }\end{array}$ & \\
\hline $5 r-90$ & 41 & & $2.1 \times 10^{4}$ & $4.1 \times 10^{3}$ & $2.5 \times 10^{4}$ \\
\hline Tc-99 & 0.36 & $4.8 \times 10^{4}$ & $1.8 \times 10^{2}$ & $3.6 \times 10^{1}$ & $4.8 \times 10^{3}$ \\
\hline$I-129$ & $<0.35$ & $1.7 \times 10^{-1}$ & $1.8 \times 10^{2}$ & $3.5 \times 10^{1}$ & $2.2 \times 10^{2}$ \\
\hline Cs-137 & 1200 & $6.1 \times 10^{6}$ & $6.0 \times 10^{5}$ & $1.2 \times 10^{5}$ & $6.8 \times 10^{6}$ \\
\hline$N p-137$ & $<0.61$ & & $3.0 \times 10^{2}$ & $6.1 \times 10^{9}$ & $3.6 \times 10^{2}$ \\
\hline $\mathrm{Pu}-239$ & 0.093 & . & $4.7 \times 10^{1}$ & 9.3 & $5.6 \times 10^{1}$ \\
\hline$A m-241$ & 1.4 & & $7.0 \times 10^{2}$ & $1.4 \times 10^{2}$ & $8.4 \times 10^{2}$ \\
\hline
\end{tabular}

Table 8-6. Isotopic Releases from the Primary Exhaust System Inventory.

\begin{tabular}{|c|c|}
\hline Isotope & Release (Ci) \\
\hline Sr-90 & $1.2 \times 10^{-2}$ \\
\hline Tc-99 & $1.3 \times 10^{-4}$ \\
\hline $\mathrm{I}-129$ & $1.0 \times 10^{-4}$ \\
\hline $\mathrm{Cs}-137$ & $1.5 \times 10^{-1}$ \\
\hline $\mathrm{Np}-237$ & $1.8 \times 10^{-4}$ \\
\hline $\mathrm{Pu}-239$ & $6.1 \times 10^{-6}$ \\
\hline $\mathrm{Am}-241$ & $5.8 \times 10^{-5}$ \\
\hline
\end{tabular}

The ingestion pathway receptor in this case is also located at the east site boundary. The difference between the site boundary dose and ingestion pathway receptor dose is due to ingestion of food produced on contaminated land. Contaminated 1 and could be taken out of production and this dose would not occur. The current version of WHC-CM-4-46 (WHC 1993) requires evaluation of ingestion dose as a measure of severity of ground contamination. The ground contamination risk is considered acceptable if potential ingestion doses are not 1 arge enough to require interdiction of food supplies or impoundment of land. That limit is taken as an ingestion dose of 500 millirem; the maximum ingestion pathway dose as shown in Table 8-8 is we 11 below that limit. 
WHC-SD-WM-SAR-064, Rev. 0

The dose consequences reported in Tables 8-7 through 8-9 are based on a ground level release. Actually, the exhaust fan is equipped with a 5-m-high stack. In addition, blowdown of overpressure from a flammable gas burn in the tank would result in exit velocities that add to the effective stack height. An elevated release would reduce the onsite doses.

Table 8-7. Ventilation System Releases Dose Consequences.

\begin{tabular}{|l|c|c|}
\hline \multirow{2}{*}{ Receptor } & \multicolumn{2}{|c|}{ Dose (rem) } \\
\cline { 2 - 3 } & EDE & Limiting organ \\
\hline $100 \mathrm{~m}$ & 1.7 & $3.5 \times 10^{1}$ \\
\hline Site boundary & $7.2 \times 10^{-4}$ & $1.5 \times 10^{-2}$ \\
\hline Ingestion pathway & $1.6 \times 10^{-2}$ & $5.7 \times 10^{-2}$ \\
\hline
\end{tabular}

$E D E$ = effective dose equivalent.

Table 8-8. Best Estimate Flammable Gas Burn Radiological Dose Consequences.

\begin{tabular}{|l|c|c|}
\hline \multirow{2}{*}{ Receptor } & \multicolumn{2}{|c|}{ Dose (rem) } \\
\cline { 2 - 3 } & EDE & Limiting organ \\
\hline $100 \mathrm{~m}$ & 4.1 & $8.0 \times 10^{1}$ \\
\hline Site boundary & $1.7 \times 10^{-3}$ & $3.4 \times 10^{-2}$ \\
\hline Ingestion pathway & $5.1 \times 10^{-2}$ & $1.3 \times 10^{-1}$ \\
\hline
\end{tabular}

EDE = effective dose equivalent.

Table 8-9. Bounding Conservative Flammable Gas Burn Radiological Dose Consequences.

\begin{tabular}{|l|c|c|}
\hline \multirow{2}{*}{ Receptor } & \multicolumn{2}{|c|}{ Dose (rem) } \\
\cline { 2 - 3 } & EDE & Limiting organ \\
\hline $100 \mathrm{~m}$ & $1.1 \times 10^{1}$ & $1.8 \times 10^{2}$ \\
\hline Site boundary & $4.7 \times 10^{-3}$ & $7.5 \times 10^{-2}$ \\
\hline Ingestion pathway & $6.2 \times 10^{-1}$ & $8.0 \times 10^{-1}$ \\
\hline
\end{tabular}

$E D E=$ effective dose equivalent. 


\subsubsection{Compliance with Risk Acceptance Guidelines}

Radiological risk acceptance guidelines have been reproduced from WHC-CM-4-46 in Table 8-10. The consequence tables show that the organ dose (bone surface) is the limiting dose. For both the reference case and the bounding case, all onsite and offsite doses meet the limits for an Anticipated Event. Because the likelihood of a flammable gas burn is below that of an Extremely Unlikely Event, as shown in the next section, the risk acceptance guidelines are met with margin.

Table 8-10. Radiological Risk Acceptance Guideline.*

\begin{tabular}{|l|c|c|c|c|}
\hline \multicolumn{1}{|c|}{$\begin{array}{c}\text { Probability } \\
\text { category }\end{array}$} & $\begin{array}{c}\text { Nominal range } \\
\text { of annual } \\
\text { probability }\end{array}$ & $\begin{array}{c}\text { Effective dose } \\
\text { equivalent } \\
\text { (rem) }\end{array}$ & $\begin{array}{c}\text { Organ dose } \\
\text { equivalent for } \\
\text { lens of eye } \\
\text { (rem) }\end{array}$ & $\begin{array}{c}\text { Organ dose } \\
\text { equivalent for } \\
\text { all other } \\
\text { organs (rem) }\end{array}$ \\
\hline \multicolumn{5}{|c|}{ 0ffsite guidel ines } \\
\hline Anticipated & 1 to $10^{-2}$ & $0.01-0.5$ & $0.03-1.5$ & $0.1-5$ \\
\hline Unlikely & $10^{-2}$ to $10^{-4}$ & $0.5-4$ & $1.5-12$ & $5-40$ \\
\hline $\begin{array}{l}\text { Extremely } \\
\text { unlikely }\end{array}$ & $10^{-4}$ to $10^{-6}$ & $4-25$ & $12-75$ & $40-250$ \\
\hline \multicolumn{5}{|c|}{ Onsite guidelines } \\
\hline Anticipated & 0.1 to $10^{-2}$ & $1-5$ & $3-15$ & $10-50$ \\
\hline Unlikely & $10^{-2}$ to $10^{-4}$ & $5-25$ & $15-75$ & $50-250$ \\
\hline $\begin{array}{l}\text { Extremely } \\
\text { unlikely }\end{array}$ & $10^{-4}$ to $10^{-6}$ & $25-100$ & $75-300$ & $250-1000$ \\
\hline
\end{tabular}

*Reproduced from guidelines in WHC-CM-4-46 (WHC 1993).

\subsection{OPERATIONAL RISK ASSESSMENT}

\subsubsection{In-Tank Ignition Sources}

Burn 1ikelihood depends on the simultaneous occurrence of a flammable gas mixture and an energy source capable of igniting it. The occurrence of a gas release and spark as separate and independent events will be discussed first, and then prospects for their occurrence as dependent events will be considered.

The mixing studies reported in Section 5.0 indicate that for this group of tanks, gas concentrations above the LFL at any location in the tanks would not exceed 112 minutes per GRE. This value is based on an LFL of $4 \%$. If the LFL were taken at 5.6\%, corresponding to the $\mathrm{H}_{2}-\mathrm{NH}_{3}$ mixture assumed, the time 
WHC-SD-WM-SAR-064, Rev. 0

at risk would be far less, and in essentially all cases the amount of fl ammable gas would be less than $1 \mathrm{~m}^{3}$. GREs in these tanks have averaged one burp per year over the past 8 years (Appendix G). Assuming an exposure time of 200 minutes per year to provide margin, the time at risk is $200 / 60 \times 24 \times 365=3.8 \mathrm{E}-4 \mathrm{yr} / \mathrm{yr}$ per tank.

In order to combine the foregoing exposure time with ignition frequency to obtain fire frequency or likelihood, the occurrence of a capable ignition source must, of course, be a random, independent event. Spark frequency as a result of in-tank instrument failure has been investigated by Powers and Morales (1994). The FIC waste level gauge was the only instrument in this group of tanks identified as having a finite unsafe potential failure frequency. However, Scaief (1994) concluded that failure probability leading to an in-tank spark is well below 1E-6 per year. A mechanism was postulated for a higher failure frequency within the electronics enclosure, but that location is external to the tank and separated from any flammable vapor.

No other credible in-vessel spark source arising from normal operations has been identified. The TV camera lights have been considered but were eliminated on tìe basis of explosion-proof design (Scaief 1994). Thus, ignition likelihood from in-tank equipment is less than the credibility threshold of 1E-6 events per year. Potential ignition sources external to the tanks such as instrumentation and ventilation fans are not considered since the flammable gas concentration would remain below the horizontal and downward flame propagation flammability limit as shown in Section 5.0 of this report.

\subsubsection{Earthquakes as an Ignition Source}

Earthquakes have been considered as potential generators of sparks from impact of loose parts (failed components) with the tank wall. For these tanks, the component of concern has been the thermocouple trees. Based on a stress analysis it has been concluded that the thermocouple trees are unlikely to fail; no other potential component failures have been identified. The performance of the thermocouple tree in tank 107-AN under seismic loads has been evaluated (Julyk 1994). The thermocouple tree is made of 2 in. Schedule 40 carbon steel pipe and is $55 \mathrm{ft}$ long. The thermocouple tree is mounted in a 4-in. riser and extends to 12-in. from the bottom primary steel liner of the tank. It is typical of the thermocouple trees used in the other DSTs. The 107-AN thermocouple tree is located $20 \mathrm{ft}$ from the tank center and at an angle of $150^{\circ}$ from the north-south centerline. The loads of interest for the earthquake evaluation are seismic ground loads and liquid sloshing. The liquid waste fluid was considered a homogenous mixture with a viscosity of $30 \mathrm{cp}$ and specific gravity of 1.4. A mixing pump was assumed to convert the $6.5 \mathrm{ft}$ of sludge and $26 \mathrm{ft}$ of 7 iquid in the tank into a homogeneous fluid. Maximum stress occurred at the upper end of the thermocouple tree and consisted of a stress value of $5,254 \mathrm{jbf} / \mathrm{in}^{2}$ resulting from the seismic load task and 23,701 $\mathrm{lbf} / \mathrm{in}^{2}$ from the liquid sloshing load for a total of $28,955 \mathrm{lbf} / \mathrm{in}^{2}$. The allowable bending stress for this loading is $30,800 \mathrm{lbf} / \mathrm{in}^{2}$. Thus, the instrument tree would not fail and is expected to remain below the elastic limit. 
The foregoing loads are based on an earthquake with a peak ground acceleration of $0.2 \mathrm{~g}$. The mean return period for exceeding that peak acceleration is 6,740 years for 200 East Area and 5,850 years for 200 West (Tallman 1989). Thus, the maximum annual frequency is $1.7 \mathrm{E}-4$ for the design basis earthquake. It is expected that applying the foregoing analysis to the DSTs in this group is conservative because of the restraint provided by the sludge in the bottom of the tank. The nonconvective layer thicknesses range from about $1 / 3$ of the waste depth in tank 101-AW to about $1 / 2$ in tank 103-SY, with the other tanks someplace in between.

Rheological data are available from tank 103-SY (Fow et al. 1986), although some dilution of the waste has occurred since those samples were obtained (see Section 3.0). The waste material from the lower parts of the waste tanks is known to be very viscous at room temperature from core sample appearance. Measurements on tank 103-SY showed apparent viscosities of 140 to $130 \mathrm{cp}$ at a shear rate of 50 to $300 / \mathrm{s}$ for the tank middle composite samples, and 1,150 to $80 \mathrm{cp}$ over the same shear rates for the bottom composite sample, both at $45^{\circ} \mathrm{C}$. (The bottom sample exhibited thixotropic behavior.) The

- convective layer in tank 101-SY was reported in Herting et al. (1992) as having viscosity of $30 \mathrm{cp}$ at $50^{\circ} \mathrm{C}$. The increased viscosity in the bottom should dampen vibration and swinging motion of the thermocouple tree.

No other failures leading to spark generation have been identified for these tanks. The other major head-mounted component not currently in the tanks, but scheduled to be installed later, is the TV camera and light assembly. The design of the assembly was found to meet seismic design requirements for a $0.33 \mathrm{~g}$ peak ground acceleration (Jones 1994).

If a seismic failure was postulated even though the design is qualified, the occurrence of a fire is still extremely unlikely. Sloshing liquid could wet the tank wall, and a gas release would have to occur at the instant the object sparked, and at the exact location. The amount of gas at flammable concentration levels is small, transient, and short-lived, as shown in Section 5.0. The occurrence of a fire would require:

1. Earthquake exceeding design basis

2. Failure of a component.

3. Collision with a sparking surface

4. Sufficient velocity to cause a spark upon impact

5. Presence of a flammable gas in sufficient amount to represent a significant energy source

6. Spark and gas occur at the same location.

Only the probability of items 1 and 5 have been quantified; and if the earthquake and burp are independent events, as they most likely are, fire frequency is below 1 E-6/yr based on those two conditions alone. 
WHC-SD-WM-SAR-064, Rev. 0

In order for a GRE to occur, a region of waste has to accumulate sufficient gas to reach the neutral buoyancy condition plus overcome viscous and hydrodynamic restraints. It is unclear how transient seismic effects would influence a rollover unless the waste region was about to rollover anyway. However, even if a connection between seismic activity and a GRE is assumed, assigning reasonable likelihoods to each of the remaining events in the foregoing list (e.g., 1 E-1) places a seismic-initiated flammable gas fire below the credibility threshold.

\subsubsection{Lightning as an Ignition Source}

Lightning strike frequency is quoted at once per $\mathrm{km}^{2} /$ year $19.3 \mathrm{E}-8$ per $\mathrm{ft}^{2}$ /year) in Powers (1992). A DST occupies $5,000 \mathrm{ft}^{2}$ so that the frequency per tank becomes $4.65 \mathrm{E}-4$ per year. The primary tank dome is covered with heavily reinforced concrete with a minimum thickness of $1 \mathrm{ft} 3 \mathrm{in}$. The primary tank is enclosed in a secondary tank constructed of reinforced concrete covered with a steel jiner that extends above the maximum waste level. There is an $18 \mathrm{in}$. annulus between the primary and secondary tank. This arrangement would appear to provide lightning protection for the interior waste tank (Faraday cage).

Head-mounted components were given additional consideration since they provide a potentially conductive pathway into the tank vapor space and waste. It was found that the energy from a lightning strike on a riser containing a component with one end immersed at least $1 \mathrm{~m}$ into the waste (e.g., an instrument tree) would be dissipated to ground through the largely ionic waste, if not dissipated before reaching that point (Cowley and Stepnewski 1994). For the case of head-mounted components that represent an arc-gap configuration by ending before entering the waste (e.g., gas sample probes) sparking is theoreticaliy possible but not likely in the DSTs. The potential spark location would be at a riser cover if it is attached over a nonconducting gasket. However, a lightning strike would be required on that particular riser. Using the rule that a tall object will attract the lightning strike occurring in an area corresponding to a circle with radius equal to the height of the object, and assuming a 4-ft riser height, the target area is equal to $50 \mathrm{ft}^{2}$. This smaller target area should reduce strike frequency by about two orders of magnitude. On this basis, spark likel ihood inside the primary tank (but in an isolated location) is about $10^{-5}$ per tank per year, assuming two such risers per tank.

The possibility that a lightning storm may influence the timing of occurrence of a GRE has been raised in the past. The lightning storms were associated with a frontal weather system and a falling barometer. It was postulated that the reduced pressure would lead to a burp. However, information from the Hanford Weather Department shows no correlation between the onset of a GRE and occurrence of lightning. For the 8 year period (19861993) thunder was recorded on 72 days. During the same 8 years, 48 GRES occurred in the 6 double-shel1 watch 1 ist tanks. None of the GREs started on days when thunder was reported. The relevant data are given in Appendix G.

With flammable gas mixture present $3.8 \mathrm{E}-4 \mathrm{yr} / \mathrm{yr}$ and spark frequency of 1 E-5/yr, burn likelihood is well below the credibility threshold on a per tank basis. 
WHC-SD-WM-SAR-064, Rev. 0

\subsubsection{Flammable Gas Burn Likelihood}

Spark frequency is summarized in Table 8-11. Ignition frequencies for the earthquake and lightning events were assumed to be the same as the annual earthquake and lightning strike frequencies. It should be emphasized that exceeding the design basis earthquake does not mean that a spark would occur, and a lightning strike does not ensure the generation of a spark in the vapor space of these DSTs.

Table 8-11. Ignition Frequency.

\begin{tabular}{|c|c|}
\hline Source & Events/yr (per tank) \\
\hline In-tank instrumentation & $<1 \times 10^{-6}$ \\
\hline Seismic & $<1.7 \times 10^{-4}$ \\
\hline Lightning & $<4.7 \times 10^{-4}$ \\
\hline
\end{tabular}

Combining the length of time at risk with the most frequent ignition source results in a burn frequency of $(3.8 \mathrm{E}-4)(4.7 \mathrm{E}-4)=1.8 \mathrm{E}-7$ per year per tank. With five tanks in this group, fiammable gas burn frequency is less than $1 E-6 / y r$. 
WHC-SD-WM-SAR-064, Rev. 0

This page intentionally left blank. 
WHC-SD-WM-SAR-064, Rev. 0

\subsection{REFERENCES}

Ballinger, M. Y., et a7., 1987, New Data for Aerosols Generated by Releases of Pressurized Powders and Solutions in Static Air, NUREG-CR-4779 (PNL-6065), Pacific Northwest Laboratory, Richland, Washington.

Bechtold, D. B., 1992, WHC Internal Memo 112100-PCL92-037, to G. D. Johnson and W. D. Winkelman, "Adiabatic Calorimetry Interim Progress Report for April 1992," April 30, 1992.

Brager, H. R., 1994, Summary of Information on Flammable Gas Watch List Tanks, WHC-EP-0711, Westinghouse Hanford Company, Richland, Washington.

Burke, T. M., 1990, FATHOMS Computer Code Software QA Package, WHC-SD-FF-ER-054, Rev. 0, Westinghouse Hanford Company, Richland, Washington.

Cashdollar, K. L., et al., 1993, Laboratory Flammability Studies of Mixtures of Hydrogen, Nitrous Oxide, and Air, Pittsburgh Research Center, Bureau of Mines, WHC-SD-WM-ES-219, Rev. 0.

Cowley, W. L. and D. D. Stepnewski, 1994, Evaluation of Hazards from Lightning Strikes to Tank Farm Facilities, WHC-SD-WM-SAR-027, Rev. 0, Westinghouse Hanford Company, Richland, Washington.

Delegard, C., 1980, Laboratory Studies of Complexed Waste Slurry Volume Growth in Tank 241-SY-101, Rockwe11 Hanford Operations, Richland, Washington.

Fow, C. L., R. D. Scheele, D. McCarthy, G. T. Thorton, W. O. Heath, and P. A. Scott, 1986, "Characterization of Waste from Double-Shell Tank 103-SY," A Letter Report for Rockwell Hanford Company, Pacific Northwest Laboratory, September 1986.

Fox, G. L., D. A. Himes, L. J. Julyk, J. Mishima, C. J. Moore, A. Padilla, B. V. Winkel, and D. D. Stepnewski, 1990, Response of Tank 241-SY-101 to a Postulated Hydrogen Burn, WHC-SD-WM-TI-426, Rev. 0, Westinghouse Hanford Company, Richland, Washington.

Fox, G. L., T. R. Beaver, 0. B. Bechtold, and A. K. Postma, 1992, Tank 241-SY-101 Crust Burn Analysis, WHC-SD-WM-SAR-046, Rev. 1, Westinghouse Hanford Company, Richland, Washington.

Fox, G. L., D. D. Stepnewski, and R. P. Anantatmula, 1993, Tank 241-SY-103. Hazard Assessment, WHC-SD-WM-SAR-061, Rev. 0, Westinghouse Hanford Company, Richland, Washington.

Fulton, J. C., 1993, WHC Letter 9360343 to R. E. Gerton, RL, Tank 241-SY-101, Safety Assessment Controls for Mitigation Mixer Pump, December 3, 1993. 
Hanlon, B. M., 1994, Tank Farm Surveillance and Waste Status Summary Report for November 1993, WHC-EP-0182-68, Westinghouse Hanford Company, Richland, Washington.

Hendrickson, D. W., 1991, Tank 241-AW-101 Characterization Results, WHC-SD-WM-TRP-055, Rev. 0, Westinghouse Hanford Company, Richiand, Washington.

Hendrickson, D. W. and J. M. Conner, 1994, Grout Treatment Facility Waste Feed Projections, WHC-SD-WM-TI-528, Rev. 1, Westinghouse Hanford Company, Richland, Washington.

Herting, D. L., D. B. Bechtold, B. A. Crawford, T. L. Welsh, and L. Jenson, 1992, Laboratory Characterization of Samples Taken in May 1991 from Hanford Waste Tank 241-SY-101, WHC-SD-WM-DTR-024, Rev. 0, Westinghouse Hanford Company, Richland, Washington.

Hey, B. E., 1993, GXQ Program Users' Guide, WHC-SD-GN-SWD-30002, EDT 141669, Westinghouse Hanford Company, Richland, Washington.

Hertzberg, Martin, 1983, "The Flammability Limits of Gases, Vapors, and Dusts: Theory and Experiment," FUEL-AIR EXPLOSIONS; University of Waterloo Press, 1982, Waterloo, Ontario, Canada.

Hi11, C. G. Jr, 1977, An Introduction to Chemical Engineering Kinetics and Reactor Design, John Wiley \& Sons, Inc., New York, New York.

Himes, D. A., 1992, "Radiological Dose Analysis of Two Hydrogen Burns in Tank 101-SY and a Sample Spill Based on Window C Samples," 29250-DAH-92015, Appendix B of Simpson et a1. (1993), Westinghouse Hanford Company, Richland, Washington.

Jakob, M., 1957, Heat Transfer, Volume II, pp. 120-123, John Wiley \& Sons, Inc., New York, New York.

Johnson, G. D., 1994, Flammable Gas Tank Safety Program Monthly Report, March 1994, WHC Internal Report, Westinghouse Hanford Company, Richland, Washington.

Jones, K. M., 1994, Waste Tank Video Camera Assembly Stress Analysis, WHC-SD-WM-DA-145, Rev. 0, February 1994.

Julyk, J. L., 1992, "Reassessment of 241-SY-101 Local Discontinuity Strains for Combined Effect of Thickness Transition and 4-inch Penetration in Dome," Appendix C of Simpson et al. (1993), Westinghouse Hanford Company, Richland, Washington.

Julyk, J. L., 1994, Tank 241-AN-107 Internal Component Structural Evaluation of Thermocouple Tree Probe (Seismic), WHC-SD-WM-ANAL-018, January 1994.

Kincaid, C. T., et al. 1993, Performance Assessment of Grouted Double-Shell Tank Waste Disposal at Hanford, WHC-SD-WM-EE-004, Rev. 0, October 1993. 
LANL, 1994, A Safety Assessment for Proposed Pump Mixing Operations to Mitigate Episodic Gas Releases in Tank 241-SY-101: Hanford Site, Richland, Washington, LA-UR-92-3196, Rev. 8, Los Alamos National Laboratory, Los Alamos, New Mexico.

Leach, C. E. and S. M. Stah1, 1993, Hanford Site Tank Farm Facilities Interim Safety Basis, Rev. 0, Section 5.3., "ISB Topical Report, Flammable Gas Waste Tanks," Westinghouse Hanford Company, Richland, Washington.

McCormack, J. D., 1992, "Estimated Aerosol Release from Tank 101-SY Hydrogen Burn," Simpson 1992, Appendix, Westinghouse Hanford Company, Richland, Washington, June 1992.

McDuffie, N. G., 1994, Flammable Gas Generation, Retention, and Release in High-Level Waste Tanks: Physical and Chemical Models, WHC-SA-2129-VA, Westinghouse Hanford Company, Richland, Washington.

Mishima, J., L. C. Schwendiman, C. A. Radasch, 1968, Plutonium Release Studies IV. Fractional Release from Heating Plutonium Nitrate Solutions in a Flowing Air Stream, BNWL-931, Battelle Northwest, Richland, Washington.

Napier, B. A., et. al, 1988, GENII - The Hanford Environmental Radiation Dosimetry Software System, PNL-6484, Pacific Northwest Laboratory, Richland, Washington.

P1ys, M. G., 1993, "Hydrogen Production and Combustion in Severe Reactor Accidents: An Integral Assessment Perspective," Nuclear Technology, Vol 101, Mar 1993.

Powers, T. B. and S. D. Morales, 1994, sY Tank Farm Ventilation Option Risk Assessment Report, WHC-EP-0579, Westinghouse Hanford Company, Richl and, Washington.

Reynolds, D. A., 1994, Evaluation of 241-AN Tank Farm Flammable Gas Behavior, WHC-EP-0717, Rev. 0, Westinghouse Hanford Company, Richland, Washington.

Scaief, C. C., 1994, WHC Internal Memo to D. D. Stepnewski, Ignition Analysis, May 24, 1994.

Simpson, D. E., R. P. Anantatmula, G. M. Christensen, C. E. Leach, D. D. Stepnewski, 1993, Flammable Gas Safety Issue Review Tank 241-SY-101, WHC-EP-0578, February 1993.

Van Vleet, R. J., 1994, Safety Basis for Activities in Double-Shell Flammable Gas Watch List Tanks, WHC-SD-WM-SARR-002, Rev. 0 , Westinghouse Hanford Company, Richland, Washington.

Van Vleet, R. J., 1993, Radionuclide and Chemical Inventories for the DoubleShell Tanks, WHC-SD-WM-TI-543, Rev. I, Westinghouse Hanford Company, Richland, Washington. 
WHC, 1992, Operating Specifications for Watch List Tanks, OSD-T-151-00030, Rev. A-1, Westinghouse Hanford Company, Richland, Washington.

WHC, 1993, Nonreactor Facility Safety Analysis Manual, WHC-CM-4-46, Westinghouse Hanford Company, Richland, Washington (refer to current version).

Wilkins, N. E., 1994, Evaluation of Tank 241-AW-101 Flammable Gas Tank Behavior, WHC-SD-WM-TI-617, Rev. 0, Westinghouse Hanford Company; Richland, Washington.

Wood, S. A., 1994, Flammable Gas Distribution in AN-AW Waste Tank Gas Space, WHC-SD-WM-ER-336, Rev. 0, Westinghouse Hanford Company, Richl and, Washington.

Tallman, A. M., 1989, Evaluation of Seismic Hazard for Nonreactor Facilities Hanford Reservation Hanford Washington, WHC-MR-0023, Westinghouse Hanford Company, Richland, Washington. 
WHC-SD-WM-SAR-064, Rev. 0

APPENDIX A

DERIVATION OF THE THERMODYNAMIC RELATIONS

AND SOLUTION PROCEDURE

$A-\mathfrak{i}$ 
WHC-SD-WM-SAR-064, Rev. 0

This page intentionally left blank. 
WHC-SD-WM-SAR-064, Rev, 0

\section{DERIVATION OF THE THERMODYNAMIC RELATIONS \\ AND SOLUTION PROCEDURE}

Consider the tank dome region to be represented a volume of combustible gas surrounded by air as shown by the diagram on the right. Variables are defined as follows:
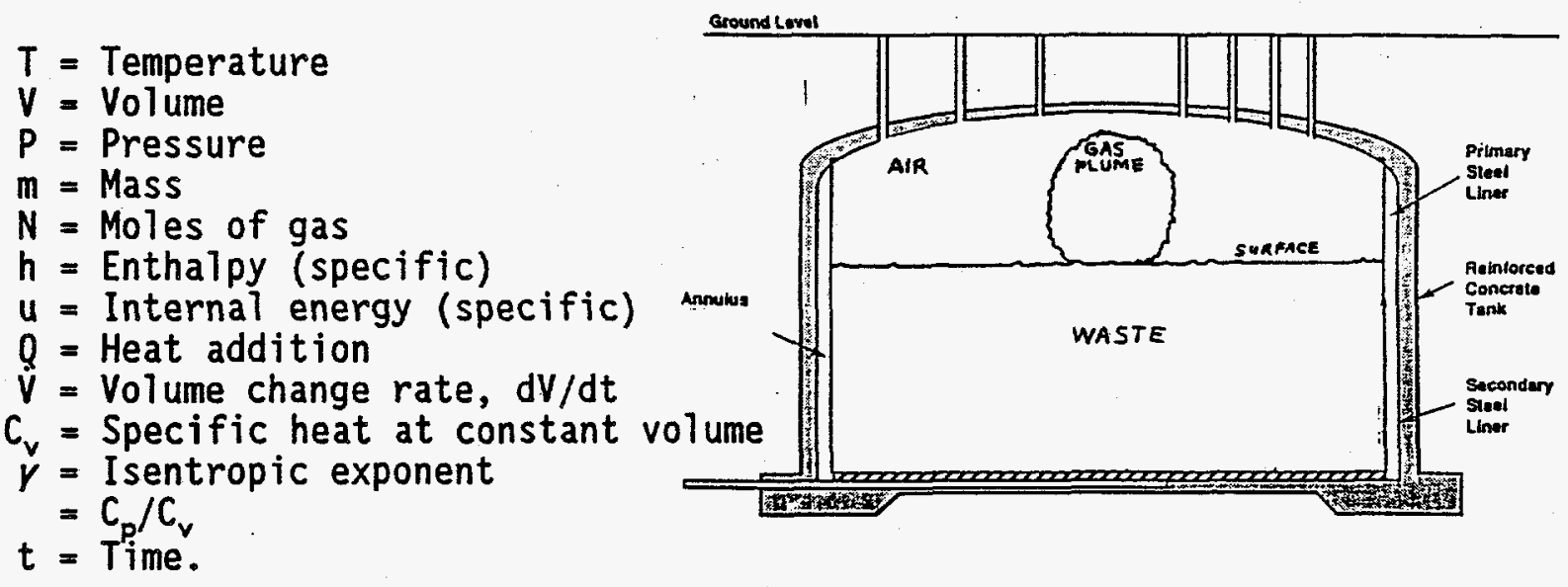

Applying on energy balance to the system volume produces:

$$
d U=d Q-d W
$$

where:

$U=$ System internal energy change

$Q=$ Heat added to system

$W=$ Work done by volume increase.

Individual terms for Equation 1 may be developed as follows:

$$
\begin{aligned}
\frac{d U}{d t}=\frac{d(m u)}{d t} & =m \frac{d u}{d t} \\
& =m \frac{d u}{d T} \frac{d T}{d t} \\
& =m C_{v} \frac{d T}{d t} \\
\frac{d W}{d t}=P \frac{d V}{d t}=P V \frac{d V}{V d t} & =m(h-u) \frac{1}{V} \frac{d V}{d t}
\end{aligned}
$$


Substituting Equations $A-2$ and $A-3$ into $A-1$ and writing in terms of rates produces the temperature rate equation.

$$
\begin{aligned}
& m C_{v} \dot{T}=\dot{Q}-m(h-u) \frac{\dot{v}}{v} \\
& \dot{T}=\frac{\dot{Q}}{m C_{v}}-\frac{(h-u)}{C_{v}} \frac{\dot{v}}{v}
\end{aligned}
$$

But it is convenient to rewrite the enthalpy and internal energy term using the definition of the isentropic exponent $\gamma$.

$$
\frac{h-u}{c_{v}}=\frac{P V}{C_{v}}=\frac{R T}{C_{v}}=(v-1) T
$$

This allows Equation A-5 to be rewritten as:

$$
\frac{\dot{T}}{T}=\frac{\dot{Q}}{m C_{v} T}-(\gamma-1) \frac{\dot{V}}{V}
$$
change.

The gas law may be used to solve for the relationship for pressure rate

$$
\frac{\dot{\mathrm{P}}}{\mathrm{P}}=\left[\frac{\dot{\mathrm{T}}}{\mathrm{T}}+\frac{\dot{\mathrm{N}}}{\mathrm{N}}-\frac{\dot{\mathrm{V}}}{\mathrm{V}}\right]
$$

Note that the pressure rate expression has been generalized to include a term for molar changes during the combustion event. Frequently the moles of product do not equal the moles of reactant. This term became necessary when the release gas was found to include numerous fuel gases (i.e., $\mathrm{H}_{2}, \mathrm{NH}_{3}, \mathrm{CH}_{4}$ and $\mathrm{CO}$ ).

Equations $A-7$ and A-8 represent the final forms to be used to solve for both the plume and the surrounding air. These equations are for a uniform gas region. $Q$ represents the heat addition from the burning plume and also the heat loss by radiation and convection. 
Equations $A-7$ and $A-8$ are written for both regions within the dome as follows: (To simplify the derivation, make the following definitions.)

$$
\begin{gathered}
Q=\frac{\dot{Q}}{m C_{V} T} \\
H=V-1 \\
\frac{\dot{T}_{A}}{T_{A}}=Q_{A}-H_{A}\left[\frac{\dot{V}}{V}\right]_{A} \\
\left.\frac{\dot{P}}{P}\right]_{A}\left[\frac{\dot{T}}{T}\right]_{A}+\left[\frac{\dot{N}}{N}\right]_{A}-\left[\frac{\dot{V}}{V}\right]_{A} \\
\frac{\dot{T}_{B}}{\dot{T}_{B}}=Q_{B}-H_{B}\left[\frac{\dot{V}}{V}\right]_{B} \\
{\left[\frac{\dot{P}}{P}\right]_{B}=\left[\frac{\dot{T}}{T}\right]_{B}-\left[\frac{\dot{P}}{\mathrm{P}}\right]_{B}} \\
{\left[\frac{\dot{V}}{A}\right]_{A}}
\end{gathered}
$$

"A" and "B" represents the plume and surrounding air respectively. These six equations may be combined and solved for the rate, $\dot{V}_{A}$. 


$$
\dot{V}_{A}=\frac{a_{A}-a_{B}+\left(\frac{\dot{N}}{N}\right)_{A}}{\left[\frac{\gamma}{V}\right]_{A}+\left[\frac{Y}{V}\right]_{B}}
$$

Now, evaluate $\dot{T}_{A}$ and $\dot{T}_{B}$ using Equations $A-10, A-12$, and $A-15 . \dot{P} / P$ may be evaluated using either Equation $A-11$ or $A-13$.

\section{Predictor-Corrector Solution}

The thermodynamic equations represented by $A-10$ through -16 are now solved using a predictor-corrector technique. The time step $\Delta t$ is defined with the subscript 1, to represent the beginning where all quantities are known, and 2, to represent the end where values must be calculated. The procedure for each region is as follows:

1. Guess $\dot{V}_{2}, Q_{2}$ and $H_{2}$ at the end of the step. (Use values from the previous step.)

2. Calculate $V_{2}=V_{1}+0.5\left(\dot{V}_{1}+\dot{V}_{2}\right) \Delta t$

$$
\begin{aligned}
& \dot{\mathrm{T}}_{2}^{2}=Q_{2}-\mathrm{H}_{2} \frac{\dot{V}_{2}}{V_{2}^{2}} \\
& \mathrm{~T}_{2}=\mathrm{T}_{1}+0.5\left(\dot{T}_{1}+\dot{T}_{2}\right) \Delta \mathrm{t} .
\end{aligned}
$$

3. Calculate a corrected value for $\dot{V}_{2}$ using Equation $A-16$ and also new $Q_{2}$ and $H_{2}$.

4. Repeat step 2 using these corrected values.

5. Step 3 and Step 2 are repeated again to improve accuracy.

6. Calculate $\dot{\mathrm{P}}_{2}$ using Equation $\mathrm{A}-11$ and all updated values.

7. Calculate $P_{2}=P_{1}+0.5\left(\dot{P}_{1}+\dot{P}_{2}\right) \Delta t$.

This completes the calculations for this time step. The procedure now sets the variables for the beginning of the next step equal to ending values for the last time step. The procedure continues over the time period of interest. 
WHC-SD-WM-SAR-064, Rev. 0

\section{APPENDIX B}

Am-241 INVENTORY IN TANK 104-AN

$B-i$ 
WHC-SD-WM-SAR-064, Rev. 0

This page intentionally left blank.

$B-i i$ 
WHC-SD-WM-SAR-064, Rev. 0.

\section{Am-241 INVENTORY IN TANK 104-AN}

The Am-241 level found in tank 101-SY crust provides about $10 \%$ of the radiological dose consequences of a postulated flammable gas fire. The Am-241 level purported to be in tank 104-AN is about two orders of magnitude greater than 101-SY crust inventory and, if true, this could significantly impact the dose consequences. Investigations of the transfer records, however, suggest that the high level is questionable. Material balances have been made on 103-AN and 104-AN to quantify the inventory discrepancy and to provide a revised estimate of the 104-AN Am-241 content.

\section{Tank 103-AN Am-241 Balance}

Transfer records provided in Table B-1 (Wanner 1992) show that of the 289,000 gal of evaporator slurry (84-3 campaign) transferred to tank 104-AN, 193,000 gal were subsequently transferred to tank 103-AN in September 1984. When 103-AN was sampled in December 1986, the surface level was almost $334.5 \mathrm{in.}$ (Reynolds 1994), equivalent to approximately $924,000 \mathrm{gal}$. The Am-241 concentration of the 84-3 campaign evaporator slurry is given in Table B-2 (Wanner 1992) as $1.14 \mathrm{E} 4 \mu \mathrm{Ci} / \mathrm{L}$. The 103-AN core sampiing, extending from top to bottom, was composited to make a representative sample. The core sample results showed an Am-241 content of $3.34 \mu \mathrm{Ci} / \mathrm{L}$. But if the 104-AN inventory actually contained the reported concentration of Am-241, then 103-AN should have $193,000 \mathrm{gal} / 924,000 \mathrm{gal}(1.14 \mathrm{E} 4)=2.38 \mathrm{E} 3 \mu \mathrm{Ci} / \mathrm{L}$, or about three orders of magnitude more than found, even when a zero concentration of Am-241 is assumed for the remainder of the 103-AN contents.

\section{Tank 104-AN Material Balance}

For the hazard evaluation of tank 104-AN, in the absence of actual sample data, the high Am-241 concentration in the 84-3 campaign slurry was assumed to be correct, and an average Am-241 concentration was calculated for the current tank contents. The mass balance, based on Table B-1, is as follows:

1,110 gal - Am-241 content not available, used 103-AN as typical for

1.069 gal transferred out this group of tanks. $(3.34 \mu \mathrm{Ci} / \mathrm{L})$

41 gal at $3.34 \mu \mathrm{Ci} / \mathrm{L}$ remaining

$289 \mathrm{gal}$ at $1.14 \mathrm{E} 4 \mu \mathrm{Ci} / \mathrm{L}$ transferred in

330 gal mixed concentration $=1 \mathrm{E} 4 \mu \mathrm{Ci} / \mathrm{L}$

193 gal transferred to $103-\mathrm{AN}$

137 gal remain at $1 E 4 \mu \mathrm{Ci} / \mathrm{L}$

910 gal sum of transfers to present time at $3.34 \mu \mathrm{Ci} / \mathrm{L}$

$\overline{1,047}$ gal current inventory
$\frac{137}{1047}$
$(1 E 4)+\frac{910}{1047}$
$(3.34)=1.31 \mathrm{E3} \mu \mathrm{Ci} / \mathrm{L}$ 
For comparison, the Grout SAR (WHC 1992) used a mean value of $1.4 \mu \mathrm{Ci} / \mathrm{L}$ for Am-241, which is the mean concentration of double-shell slurry feed waste from tanks 101-AN, 103-AN, and 106-AN. The bounding source term given in the grout $S A R$, increased over the mean to allow for uncertainties, is $3.6 \mu \mathrm{Ci} / \mathrm{L}$ for $A m-241$. The value we have used for 104-AN is approximately a factor of 400 greater.

Table B-1. Fill history for Tank 104-AN (Wanner 1992).

\begin{tabular}{|c|c|c|}
\hline Dates & $\begin{array}{c}\text { Transfers } \\
\text { (to/from) }\end{array}$ & $\begin{array}{c}\text { Amount transferred } \\
\text { (ga7.) }\end{array}$ \\
\hline $11 / 7 / 82-12 / 6 / 82$ & $\begin{array}{l}\text { Evaporator slurry } \\
\text { recd. (83-1 campaign) }\end{array}$ & 1.11 million \\
\hline $2 / 27 / 84-3 / 1 / 84$ & To 102-AZ & $570 \mathrm{~K}$ \\
\hline $3 / 1 / 84-3 / 6 / 84$ & To 105-AN & $499 \mathrm{~K}$ \\
\hline $3 / 9 / 84-3 / 14 / 84$ & $\begin{array}{l}\text { Evaporator slurry } \\
\text { recd. (84-5 campaign) }\end{array}$ & $289 \mathrm{~K}$ \\
\hline $9 / 18 / 84-9 / 25 / 84$ & T0 103-AN & $193 \mathrm{~K}$ \\
\hline $9 / 26 / 84-9 / 30 / 84$ & $\begin{array}{l}\text { Evaporator slurry } \\
\text { recd. (84-5 campaign) }\end{array}$ & $89 \mathrm{~K}$ \\
\hline $10 / 13 / 84-10 / 22 / 84$ & $\begin{array}{l}\text { Evaporator slurry } \\
\text { recd. (84-5 campaign) }\end{array}$ & $100 \mathrm{~K}$ \\
\hline $4 / 12 / 85-4 / 15 / 85$ & $\begin{array}{l}\text { Evaporator slurry } \\
\text { recd. }\end{array}$ & $121 \mathrm{~K}$ \\
\hline
\end{tabular}


Table B-2. Chemical Composition of Evaporator Campaign 84-3 Sample (R9991) July 1984 (Wanner 1992).

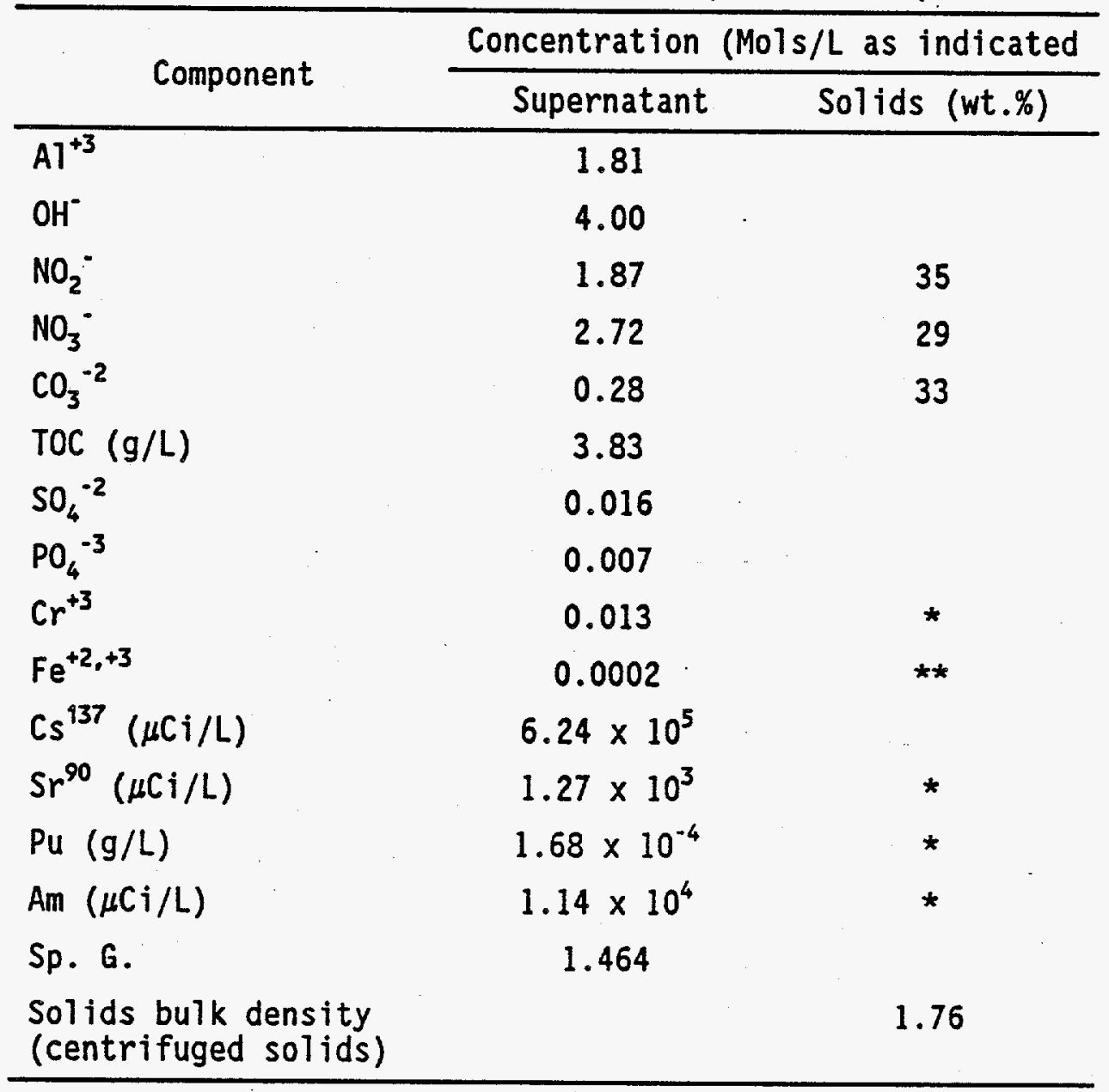

* Not included in weight percent.

**Below detection limits.

\section{References}

Wanner, D. D., 1992, "Information Needs For Tank 104-AN," WHC internal memo to W. L. Cowley 72500-92-017, dated March 12, 1992.

WHC, 1992, Grout Treatment Facility Analysis Report, WHC-SD-WM-SAR-042, November 1992. 
WHC-SD-WM-SAR-064, Rev. 0

This page intentionally left blank. 
WHC-SD-WM-SAR-064, Rev. 0

APPENDIX C

CALCULATION OF THERMAL RELEASE COMPONENT OF RADIOLOGICAL SOURCE TERM 
WHC-SD-WM-SAR-064, Rev. 0

This page intentionally left blank.

$c-i j$ 
WHC-SD-WM-SAR-064, Rev. 0

\section{CALCULATION OF THERMAL RELEASE COMPONENT OF RADIOLOGICAL SOURCE TERM}

The thermal release was calculated by the methods of McCormack (1992), which assume the gases emanating from the crust heated by the plume burn are saturated in the volatile radionuclides present in the crust. The gases released from the heated crust consist of water vapor and gaseous product from oxidation of organic carbon by nitrates. As it turned out, the volume of the gaseous reaction products was small compared to the water vapor volume and was therefore neglected.

The vapor pressure of the volatile radionuclides in the crust was based on the data for $\mathrm{CsI}, \mathrm{KTCO}_{4}$, and $\mathrm{CsOH}$ as developed in McCormack (1992). The equations written for the vapor pressure plots provided in McCormack (1992) are provided in the attached spreadsheets.

The spreadsheet shows the water vapor generated from each concentric crust surface node, radiating outward from the plume center line. The water inventory is released from each ring, down to the depth at which the calculated crust temperature falls below $266^{\circ} \mathrm{F}\left(130^{\circ} \mathrm{C}\right)$. The total amount of water vapor from each set of vertical nodes is assumed to become saturated in radionuclide vapor at the average temperature of the surface node. Actually the arithmetic average of the vapor pressure at the temperature of the two node faces was used. The water release from each node is shown on the spreadsheet along with the temperature, partial pressure, and radionuclide release for each node. The cesium vapor pressure calculation is corrected for the ratio of $\mathrm{Cs}-137$ to total cesium; a value of 0.34 was used (Van Tuyl 1962).

Gaseous reaction products would serve to strip out volatile fission products in the same manner as the water vapor. McCormack (1992) estimated the production of $2.8 \mathrm{~L}$ of gas per gram of total organic carbon, or $0.053 \mathrm{~L} / \mathrm{g}$ $\left(5.3 \mathrm{E}-5 \mathrm{~m}^{3} / \mathrm{g}\right)$ of reacted crust. The mass of reacted crust was $399 \mathrm{~g}$ and $11,148 \mathrm{~g}$ respectively for the best estimate and conservative cases. The spreadsheet shows the release of $17.32 \mathrm{~kg}$ water $\left(21.6 \mathrm{~m}^{3}\right)$, and $50 \mathrm{~kg}$ water $\left(62.3 \mathrm{~m}^{3}\right)$ for the best estimate and conservative caşes, respectjuely. The volume of gaseous reaction products would be $0.02 \mathrm{~m}^{3}$ and $0.59 \mathrm{~m}^{3}$, respectively, for the best estimate and conservative cases. The corresponding water vapor to reaction products ratios are $21.6 / 0.02=1080$ and $62.3 / 0.59=105.6$. Since the gaseous reaction products are less than $1 \%$ of the vapor released, they are neglected in the volatile nuclide stripping calculation.

In calculating the release of $\mathrm{Cs}-137$, a cutoff temperature of $700^{\circ} \mathrm{F}$ was used, the melting point of sodium nitrate. When the crust mixture reaches the melting point, the vapor stripping mechanism assumed in this analysis would no longer be applicable. The cesium compounds would dissolve in the mixture of sodium salts and the partial pressure of cesium salts should then follow 


$$
\text { WHC-SD-WM-SAR-064, Rev . } 0
$$

Raoult's law. The mole fractions of the nitrates, aluminates, and hydroxides in the crust will dominate the solution, and the mole fraction of $\mathrm{CSOH}$ will be very small, resulting in a negligible partial pressure of $\mathrm{CsOH}$. Thus, after reaching $700^{\circ} \mathrm{F}$, no more $\mathrm{CsOH}$ is assumed to come off. The limit temperature of $700^{\circ} \mathrm{F}$ is the melting point of the highest melting major constituent in the crust. In reality, the mixture would very likely melt at a lower temperature owing to eutectic formation.

References

McCormack, J. D., 1992, "Estimated Aerosol Release from Tank 101-SY Hydrogen Burn," as presented in Simpson et al. 1993, Westinghouse Hanford Company, Richland, Washington.

Van Tuy1, H. H., 1962, Fission Product Generation and Decay Calibrations, HW-75978, General Electric Co., Rich land, Washington.

C-2 
WHC-SD-WM-SAR-064, Rev. 0

ESTIMATE RADIOACTIVE RELEASES FROM HEATED CRUST

First, develop curve fit for vapor pressures

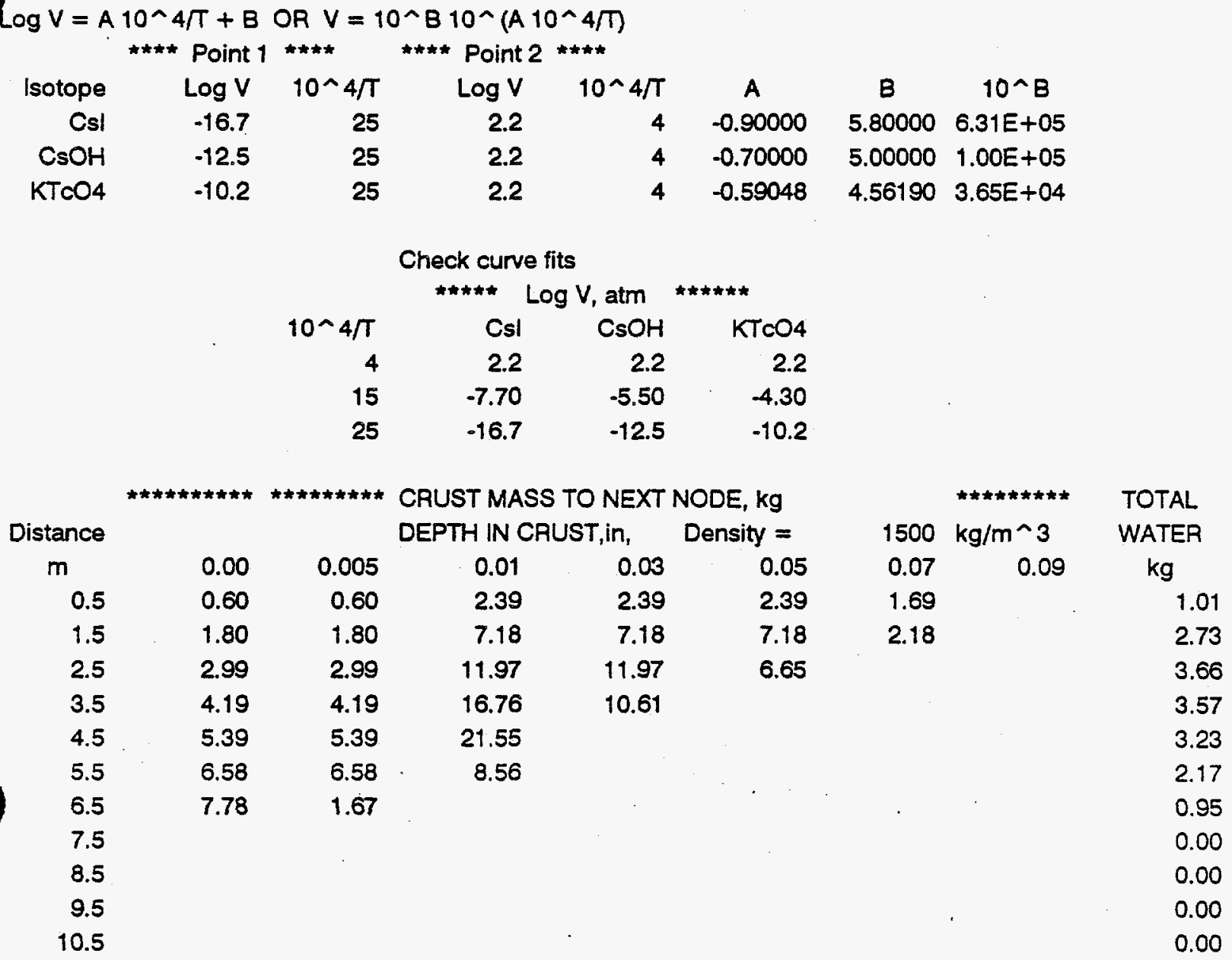

\section{BEST ESTIMATE CONDITIONS}

\section{Distance}

$\mathrm{m}$

0.5

1.5

2.5

3.5

4.5

5.5

6.5

7.5

8.5

9.5

10.5

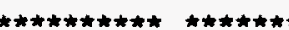

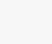

$\begin{array}{rr}0.00 & 0.005 \\ 671 & 583 \\ 606 & 530 \\ 514 & 452 \\ 429 & 383 \\ 369 & 335 \\ 323 & 298 \\ 289 & 269 \\ 263 & \\ 243 & \\ 227 & \\ 214 & \end{array}$

MAXIMUM CRUST TEMPERATURE, DEG F DEPTH IN CRUST, IN

$\begin{array}{lllll}0.01 & 0.03 & 0.05 & 0.07 & 0.09 \\ 519 & 367 & 308 & 283 & 259 \\ 472 & 344 & 295 & 273 & 250 \\ 407 & 313 & 276 & 258 & \end{array}$


BEST ESTIMATE CONDITIONS

MATE CONDITIONS CSI

\begin{tabular}{rrrrrrrrr} 
Distance & & \multicolumn{5}{c}{ DEPTH IN CRUST, } & T cutoff= & 700 deg F \\
$m$ & 0.00 & 0.005 & 0.01 & 0.03 & 0.05 & 0.07 & 0.09 \\
0.5 & $2.995 E-09$ & $1.85 E-10$ & $1.789 E-11$ & $1.626 E-14$ & $5.085 E-16$ & $9.92 E-17$ & \\
1.5 & $4.009 E-10$ & $2.73 E-11$ & $2.618 E-12$ & $4.475 E-15$ & $2.203 E-16$ & $5 E-17$ & \\
2.5 & $1.471 E-11$ & $1.09 E-12$ & $1.303 E-13$ & $6.961 E-16$ & $6.154 E-17$ & $1.73 E-17$ & \\
3.5 & $3.778 E-13$ & $3.83 E-14$ & $6.678 E-15$ & $1.135 E-16$ & $1.389 E-17$ & & \\
4.5 & $1.813 E-14$ & $2.65 E-15$ & $6.142 E-16$ & $1.995 E-17$ & & & \\
5.5 & $1.289 E-15$ & $2.68 E-16$ & $7.559 E-17$ & $4.208 E-18$ & & \\
6.5 & $1.483 E-16$ & $3.78 E-17$ & $1.389 E-17$ & & & & \\
7.5 & $2.474 E-17$ & & & & & & \\
8.5 & $5.7 E-18$ & & & & & &
\end{tabular}

WHC-SD-WM-SAR-064, ReV. O

WHC-SD-WM-SAR-064, Rev。0

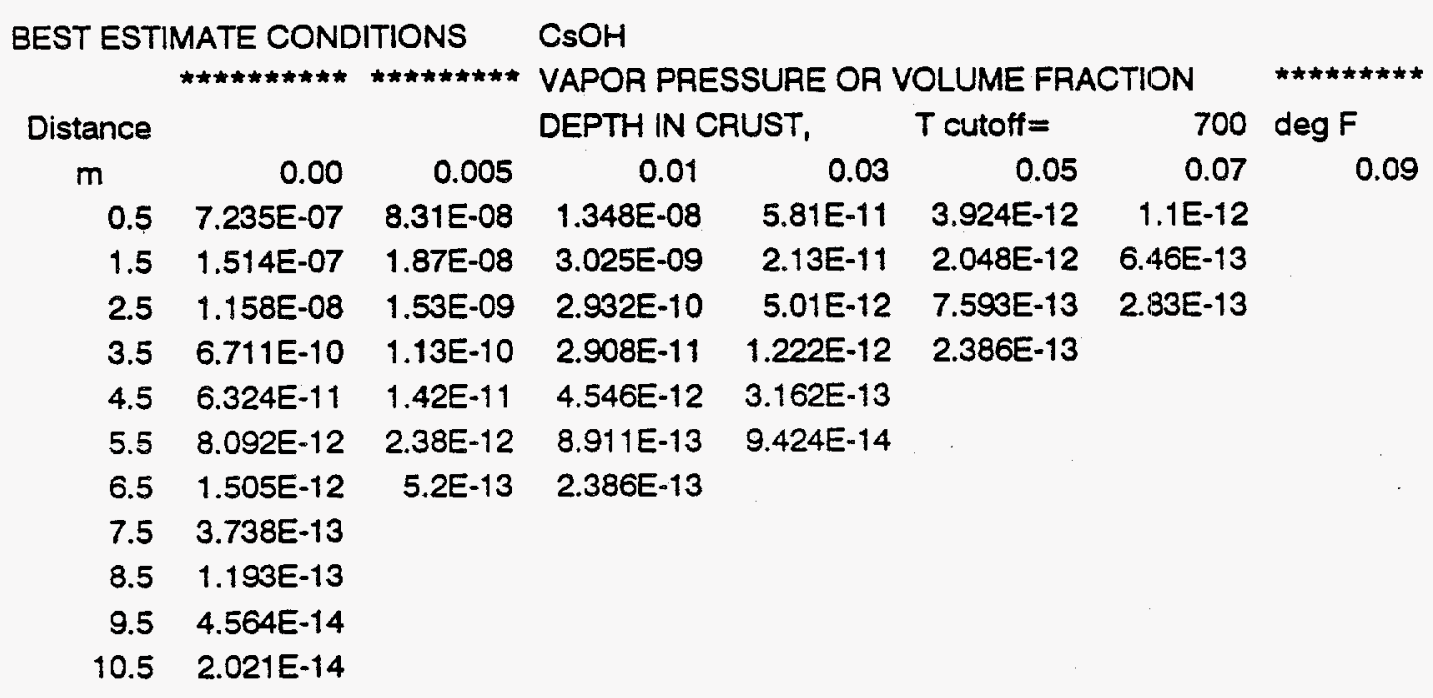

\begin{tabular}{|c|c|c|c|c|c|c|c|}
\hline \multicolumn{3}{|c|}{ BEST ESTIMATE CONDITIONS } & \multicolumn{5}{|l|}{$\mathrm{KTCO} 4$} \\
\hline & 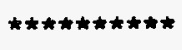 & 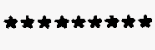 & \multicolumn{4}{|c|}{ VAPOR PRESSURE OR VOLUME FRACTION. } & \\
\hline Distance & & & DEPTH IN C & RUST, & T cutoff $=$ & 700 & $\operatorname{deg} F$ \\
\hline m & 0.00 & 0.005 & 0.01 & 0.03 & 0.05 & 0.07 & 0.09 \\
\hline 0.5 & 1.46E-05 & 2.35E-06 & 5.073E-07 & 5.127E-09 & 5.279E-10 & $1.81 E-10$ & \\
\hline 1.5 & $3.902 E-06$ & $6.7 E-07$ & $1.438 \mathrm{E}-07$ & 2.199E-09 & $3.05 E-10$ & $1.15 E-10$ & \\
\hline 2.5 & 4.462E-07 & 8.09E-08 & $2.008 E-08$ & $6.487 E-10$ & $1.321 E-10$ & $5.74 E-11$ & \\
\hline 3.5 & $4.038 E-08$ & 8.99E-09 & 2.86E-09 & $1.974 E-10$ & 4.974E-11 & & \\
\hline 4.5 & $5.506 E-09$ & 1.56E-09 & $5.976 E-10$ & $6.308 E-11$ & & & \\
\hline 5.5 & $9.72 E-10$ & 3.47E-10 & $1.512 \mathrm{E}-10$ & $2.272 E-11$ & & & \\
\hline 6.5 & $2.352 E-10$ & 9.6E-11 & 4.974E-11 & & & & \\
\hline 7.5 & 7.264E-11 & & & & & & \\
\hline 8.5 & 2.773E-11 & & & & & & \\
\hline 9.5 & $1.233 \mathrm{E}-11$ & & & & & & \\
\hline 10.5 & $6.2 E-12$ & & & & & & \\
\hline
\end{tabular}


WHC-SD-WM-SAR-064, Rev. 0

VAPOR PROPERTIES

MOLECULE SPECIFIC ISOTOPE RADIO- COMPOUND

ISOTOPE WEIGHT VOLUME ACTIVITY ACTIVE ACTIVITY

$\mathrm{H} 2 \mathrm{O}$ $\mathrm{m}^{\wedge} 3 / \mathrm{kg} \mathrm{microCi/kg}$

FRACTION microCi/kg

CsI

1.2457

$\overline{1.000}$

0

$\mathrm{CsOH}$

260

0.0862

$1.80 E+05$

$8.79 E+04$

151

0.1485

$8.70 E+10$

0.340

$2.61 E+10$

$\mathrm{KTCO} 4$

$0.1109 \quad 1.70 E+07$

1.000

8.33E+06

BEST ESTIMATE CONDITIONS

\begin{tabular}{|c|c|c|c|c|c|c|c|c|c|}
\hline 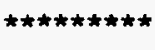 & 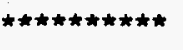 & \multicolumn{5}{|c|}{ ISOTOPES RELEASED WITH WATER VAPOR } & \multicolumn{3}{|c|}{ 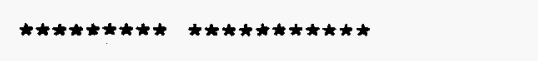 } \\
\hline Distance & 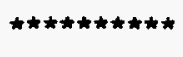 & 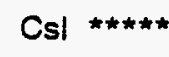 & 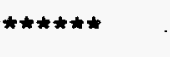 & 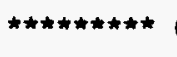 & $\mathrm{sOH} \star * \star \star \star$ & & & $\mathrm{KTCO} 4 * \star \star \star$ & \\
\hline m & $m \wedge 3$ & $\mathrm{~kg}$ & microCi & $m^{\wedge} 3$ & $\mathrm{~kg}$ & microCi & $m^{\wedge} 3$ & $\mathrm{~kg}$ & microCi \\
\hline 0.5 & $1.99 E-09$ & 2.31E-08 & 2.03E-03 & 5.06E-07 & 3.41E-06 & 8.87E+04 & $1.06 E-05$ & $9.58 E-05$ & $7.98 E+02$ \\
\hline 1.5 & $7.28 E-10$ & 8.45E-09 & 7.43E-04 & 2.89E-07 & 1.95E-06 & $5.08 E+04$ & $7.78 E-06$ & $7.01 E-05$ & $5.84 E+02$ \\
\hline 2.5 & $3.60 E-11$ & 4.17E-10 & 3.67E-05 & 2.99E-08 & 2.01E-07 & $5.24 E+03$ & $1.20 E-06$ & $1.08 E-05$ & $9.01 E+01$ \\
\hline 3.5 & $9.26 E-13$ & 1.07E-11 & $9.44 E-07$ & $1.75 E-09$ & $1.18 E-08$ & $3.06 E+02$ & $1.10 E-07$ & 9.91E-07 & $8.25 E+00$ \\
\hline 4.5 & 4.18E-14 & $4.85 E-13$ & 4.26E-08 & $1.56 \mathrm{E}-10$ & 1.05E-09 & $2.73 E+01$ & $1.42 E-08$ & 1.28E-07 & $1.07 E+00$ \\
\hline 5.5 & $2.11 E-15$ & $2.44 E-14$ & 2.15E-09 & $9.42 E-11$ & $9.55 E-11$ & $2.49 E+\infty 0$ & 1.78E-09 & $1.61 E-08$ & $1.34 \mathrm{E}-01$ \\
\hline 6.5 & $1.10 E-16$ & $1.27 E-15$ & $1.12 \mathrm{E}-10$ & $1.19 E-12$ & 8.03E-12 & 2.09E-01 & $1.95 E-10$ & $1.76 \mathrm{E}-09$ & $1.46 \mathrm{E}-02$ \\
\hline 7.5 & $0.00 E+00$ & $0.00 E+00$ & $0.00 E+00$ & $0.00 E+00$ & $0.00 E+00$ & $0.00 E+00$ & $0.00 E+00$ & $0.00 E+00$ & $0.00 E+00$ \\
\hline 8.5 & $0.00 E+\infty 0$ & $0.00 E+00$ & $0.00 E+00$ & $0.00 E+\infty 0$ & $0.00 E+00$ & $0.00 E+00$ & $0.00 E+00$ & $0.00 E+00$ & $0.00 E+00$ \\
\hline 9.5 & $0.00 E+00$ & $0.00 E+\infty 0$ & $0.00 E+00$ & $0.00 E+00$ & $0.00 E+00$ & $0.00 E+00$ & $0.00 E+00$ & $0.00 E+00$ & $0.00 E+00$ \\
\hline 10.5 & $0.00 E+00$ & $0.00 E+\infty 0$ & $0.00 E+00$ & $0.00 E+00$ & $0.00 E+\infty 0$ & $0.00 E+00$ & $0.00 E+00$ & $0.00 E+00$ & $0.00 E+00$ \\
\hline & SUM & $3.20 E-08$ & 2.81E-03 & & 5.57E-06 & $1.45 E+05$ & & $1.78 E-04$ & $1.48 E+03$ \\
\hline
\end{tabular}

\begin{tabular}{|c|c|c|c|c|c|c|c|}
\hline \multirow[b]{2}{*}{ Distance } & \multirow[t]{2}{*}{ 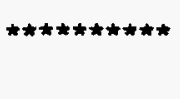 } & $* * * \star \pi$ & \multicolumn{4}{|c|}{ CESIUM RADIOACTIVITY AVAILABLE, micrOCi } & \multirow{3}{*}{$\begin{array}{r}\text { microCi/g } \\
0.09\end{array}$} \\
\hline & & & DEPTH IN C & QUST,in, & Activity $=$ & 1200 & \\
\hline$m$ & 0.00 & 0.005 & 0.01 & 0.03 & 0.05 & 0.07 & \\
\hline 0.5 & $7.18 E+05$ & $7.18 E+05$ & $2.87 E+06$ & 2.87E+06 & $2.87 E+06$ & $2.03 E+06$ & \\
\hline 1.5 & $2.15 E+06$ & $2.15 E+06$ & $8.62 E+06$ & $8.62 E+06$ & $8.62 E+06$ & $2.62 E+06$ & \\
\hline 2.5 & $3.59 E+06$ & $3.59 E+06$ & $1.44 E+07$ & $1.44 E+07$ & $7.98 E+06$ & & \\
\hline 3.5 & $5.03 E+06$ & $5.03 E+06$ & $2.01 E+07$ & $1.27 E+07$ & & & \\
\hline $4.5^{\circ}$ & $6.46 E+06$ & $6.46 E+06$ & $2.59 E+07$ & & & & \\
\hline 5.5 & $7.90 \mathrm{E}+06$ & $7.90 E+06$ & $1.03 E+07$ & & & & \\
\hline 6.5 & $9.34 E+06$ & $2.00 E+06$ & & & & & \\
\hline 7.5 & $0.00 E+00$ & & & & & & \\
\hline 8.5 & $0.00 E+00$ & & & & & & \\
\hline 9.5 & $0.00 E+00$ & & & & & & \\
\hline 10.5 & $0.00 E+00$ & & & & & & \\
\hline SUM & $3.52 E+07$ & $2.79 E+07$ & $8.21 E+07$ & $3.86 E+07$ & $1.95 E+07$ & $4.64 E+06$ & $0.00 E+00$ \\
\hline
\end{tabular}


WHC-SD-WM-SAR-064, Rev. 0

CONSERVATIVE CASE

\begin{tabular}{|c|c|c|c|c|c|c|c|c|}
\hline \multirow{2}{*}{$\begin{array}{l}\text { Distance } \\
\mathrm{m}\end{array}$} & \multirow{2}{*}{$\begin{array}{r}\star \star \star \star \star \star \star \star \star \star \star * \\
0.00\end{array}$} & 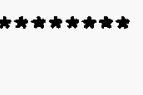 & \multicolumn{3}{|c|}{$\begin{array}{l}\text { MAXIMUM CRUST TEMPERATURE, DEG } \\
\text { DEPTH IN CRUST, IN }\end{array}$} & \multicolumn{2}{|c|}{ 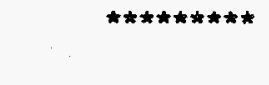 } & \multirow[b]{2}{*}{0.25} \\
\hline & & 0.005 & 0.01 & 0.05 & 0.09 & 0.13 & 0.17 & \\
\hline 0.5 & 1860 & 1711 & 1535 & 656 & 395 & 306 & 273 & 235 \\
\hline 1.5 & 1342 & 1264 & 1485 & 534 & 339 & 282 & 267 & 215 \\
\hline 2.5 & 982 & 838 & 729 & 354 & 280 & 250 & & \\
\hline 3.5 & 762 & 654 & 567 & 307 & 257 & & & \\
\hline 4.5 & 569 & 508 & 449 & 278 & 237 & & & \\
\hline 5.5 & 455 & 400 & 363 & 254 & & & & \\
\hline 6.5 & 385 & 346 & 319 & 235 & & & & \\
\hline 7.5 & 338 & 308 & 287 & 220 & & & & \\
\hline 8.5 & 304 & 279 & $2 ఱ 3$ & & & & & \\
\hline 9.5 & 279 & 258 & & & & & & \\
\hline 10.5 & 259 & & & & & & & \\
\hline
\end{tabular}

CONSERVATIVE CASE

$\begin{array}{crr}\text { Distance } & & \\ m & & \\ 0.5 & 0.00 & 0.005 \\ 1.5 & 0.60 & 0.60 \\ 2.5 & 1.80 & 1.80 \\ 3.5 & 2.99 & 2.99 \\ 4.5 & 4.19 & 4.19 \\ 5.5 & 5.39 & 5.39 \\ 6.5 & 6.58 & 6.58 \\ 7.5 & 7.78 & 7.78 \\ 8.5 & 10.98 & 8.98 \\ 9.5 & 7.04 & 8.26 \\ 10.5 & & \end{array}$

CRUST MASS TO NEXT NODE, $\mathrm{kg}$ DEPTH IN CRUST,in,

$\begin{array}{rrr}0.01 & 0.05 & 0.09 \\ 4.79 & 4.79 & 4.79 \\ 14.36 & 14.36 & 14.36 \\ 23.94 & 23.94 & 11.17 \\ 33.51 & 33.51 & \\ 43.09 & 12.61 & \end{array}$

52.67

62.24

22.51

$\begin{array}{rcc} & \star \star \star \star \star \star \star \star \star & \text { TOTAL } \\ 1500 \mathrm{~kg} / \mathrm{m} \wedge 3 & \text { WATER } \\ 0.13 & 0.17 & \mathrm{~kg} \\ 4.79 & 1.76 & 2.21 \\ 14.36 & 0.55 & 6.16 \\ & & 6.50 \\ & & 7.54 \\ & & 6.65 \\ & & 6.58 \\ & & 7.78 \\ & & 4.05 \\ & & 1.84 \\ & & 0.70 \\ & & 0.00\end{array}$

\begin{tabular}{|c|c|c|c|c|c|c|c|}
\hline \multicolumn{3}{|c|}{ CONSERVATIVE CASE } & \multicolumn{5}{|l|}{ Csi } \\
\hline Distance & & & DEPTH IN C & JST, & $\mathrm{T}$ cutoff $=$ & 700 & $\operatorname{deg} F$ \\
\hline $\mathrm{m}$ & 0.00 & 0.005 & 0.01 & 0.05 & 0.09 & 0.13 & 0.17 \\
\hline 0.5 & 6.83E-09 & $6.83 E-09$ & $6.83 E-09$ & $1.92 E-09$ & $7.12 E-14$ & $4.48 E-16$ & \\
\hline 1.5 & $6.83 E-09$ & $6.83 E-09$ & 6.83E-09 & $3.18 \mathrm{E}-11$ & $3.35 E-15$ & $9.27 \mathrm{E}-17$ & \\
\hline 2.5 & 6.83E-09 & $6.83 E-09$ & 6.83E-09 & $7.91 E-15$ & $8.09 E-17$ & $9.62 E-18$ & \\
\hline 3.5 & $6.83 E-09$ & $1.81 E-09$ & $1.06 \mathrm{E}-10$ & 4.77E-16 & $1.61 \mathrm{E}-17$ & & \\
\hline 4.5 & $1.14 \mathrm{E}-10$ & $1.16 E-11$ & $9.51 E-13$ & $7.06 \mathrm{E}-17$ & 3.61E-18 & & \\
\hline 5.5 & $1.24 \mathrm{E}-12$ & $9.18 E-14$ & $1.31 E-14$ & $1.29 E-17$ & & & \\
\hline 6.5 & 4.25E-14 & $5.02 E-15$ & $1.01 E-15$ & $3.09 E-18$ & & & \\
\hline 7.5 & $3.16 E-15$ & $5.08 E-16$ & $1.30 E-16$ & $9.47 E-19$ & & & \\
\hline 8.5 & $3.94 E-16$ & $7.56 \mathrm{E}-17$ & 2.47E-17 & & & & \\
\hline 9.5 & $7.56 \mathrm{E}-17$ & $1.73 \mathrm{E}-17$ & & & & & \\
\hline 10.5 & $1.86 \mathrm{E}-17$ & & & & & & \\
\hline
\end{tabular}


CONSERVATIVE CASE

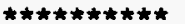

Distance

$\mathrm{m}$

1.374E-06

1.374E-06

1.374E-06

1.374E-06

5.69E-08

1.696E-09

$6.51 .006 E-09$

6.5 1.227E-10

$7.5 \quad 1.624 \mathrm{E}-11$

$8.5 \quad 3.22 E-12$

$9.5 \quad 8.911 E-13$

$10.5 \quad 2.99 E-13$
$\mathrm{CsOH}$

WHC-SD-WM-SAR-064, Rev. 0

VAPOR PRESSURE OR VOLUME FRACTION

DEPTH IN CRUST,

$T$ cutoff $=$

0.09

0.13

$\operatorname{deg} F$

1.37E-06

1.37E-06

1.37E-06

4.89E-07

9.63E-09

2. $23 E-10$

2.33E- 11

3.92E-12

8.91E-13

2. $83 E-13$

$$
0.01
$$

1.374E-06

1.374E-06

1.374E-06

5.386E-08

1.376E-09

4.9E-11

6.69E-12

1.357E-12

$3.738 \mathrm{E}-13$

\subsection{E-07}

2.108E-08

$1.833 E-10$

1.699E-11

3.56E-12

3.318E-11

3.736E-12

$8.449 \mathrm{E}-13$

9.397E-13

2.672E-13

2.254E-13

7.422E-14

2.955E-14

8.366E-14

1.04E-12

1.79E-13
CONSERVATIVE CASE

$\begin{array}{rrr}\text { Distance } & & \\ m & 0.00 & 0.005 \\ 0.5 & 2.51 E-05 & 2.51 E-05 \\ 1.5 & 2.51 E-05 & 2.51 E-05 \\ 2.5 & 2.51 E-05 & 2.51 E-05 \\ 3.5 & 2.51 E-05 & 1.05 E-05 \\ 4.5 & 1.71 E-06 & 3.82 E-07 \\ 5.5 & 8.83 E-08 & 1.60 E-08 \\ 6.5 & 9.63 E-09 & 2.37 E-09 \\ 7.5 & 1.75 E-09 & 5.28 E-10 \\ 8.5 & 4.47 E-10 & 1.51 E-10 \\ 9.5 & 1.51 E-10 & 5.74 E-11 \\ 10.5 & 6.02 E-11 & \end{array}$

$\mathrm{KTCO} 4$

VAPOR PRESSURE OR VOLUME FRACTION DEPTH IN CRUST, $T$ cutoff $=$ 0.09

700

0.13

$\operatorname{deg} F$

251E-05

$1.09 E-05$

1.35E-08

4.86E-10

2.51E-05

2.51E-05

$1.63 E-06$

7.40E-08

4. $44 E-09$

$8.28 \mathrm{E}-10$

2.16E-10

7.26E-11
3.20E-09

$5.06 \mathrm{E}-10$

1.45E-10

4.74E-11

1.86E-11

8.54E-12

\subsection{E-07}

1.82E-09 1.73E-10

1.58E-10 3.91E-11

5.47E-11

2.05E-11

CONSERVATIVE CASE

\begin{tabular}{|c|c|c|c|}
\hline stance & & Cs1 ** & 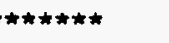 \\
\hline$m$ & $m^{\wedge} 3$ & $\mathrm{~kg}$ & microCi \\
\hline 0.5 & $1.88 E-08$ & $2.18 E-07$ & $1.92 E-02$ \\
\hline 1.5 & $5.24 E-08$ & 6.08E-07 & $5.34 \mathrm{E}-02$ \\
\hline 2.5 & 5.53E-08 & 6.42E-07 & $5.64 E-02$ \\
\hline 3.5 & 4.06E-08 & 4.71E-07 & $4.14 E-02$ \\
\hline 4.5 & $5.20 E-10$ & $6.03 E-09$ & $5.30 E-04$ \\
\hline 5.5 & $5.48 E-12$ & $6.35 E-11$ & 5.59E-06 \\
\hline 6.5 & $2.30 \mathrm{E}-13$ & 2.67E-12 & 2.35E-07 \\
\hline 7.5 & $9.24 E-15$ & $1.07 \mathrm{E}-13$ & $9.42 E-09$ \\
\hline 8.5 & 5.39E-16 & $6.26 E-15$ & $5.50 \mathrm{E}-10$ \\
\hline 9.5 & $4.07 E-17$ & $4.72 E-16$ & $4.15 E-11$ \\
\hline \multirow[t]{2}{*}{10.5} & $0.00 E+00$ & $0.00 E+00$ & $0.00 E+00$ \\
\hline & SUM & 1.94E-06 & 1.71E-01 \\
\hline
\end{tabular}

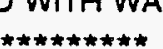
$m \wedge 3$
3.78E-06
1.05E-05
1.11E-05
8.75E-06
2.75E-07
7.87E-09
7.07E-10
5.08E-11
4.72E-12
$5.15 E-13$
$0.00 E+00$

VR VAPOR

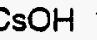

5.89E-05 1.54E+O6

1.85E-06 4.83E+04

$5.30 \mathrm{E}-08 \quad 1.38 \mathrm{E}+03$

4.76E-09 1.24E+02

$3.42 E-10 \quad 8.92 E+00$

3.18E-11 8.28E-01

3.47E-12 9.03E-02

$0.00 E+00 \quad 0.00 E+00$

2.32E-04 $6.05 E+06$

\begin{tabular}{|c|c|c|}
\hline$* \star \star \star \star \star \star \star * \star x$ & 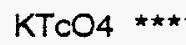 & 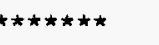 \\
\hline$m^{\wedge} 3$ & $\mathrm{~kg}$ & microCi \\
\hline $6.91 E-05$ & $6.22 E-04$ & $5.18 \mathrm{E}+03$ \\
\hline $1.92 E-04$ & $1.73 E-03$ & $1.44 E+04$ \\
\hline 2.03E-04 & $1.83 E-03$ & $1.52 E+04$ \\
\hline $1.67 E-04$ & $1.51 E-03$ & $1.25 E+04$ \\
\hline-06 & 7.80E-05 & $6.50 E+02$ \\
\hline-07 & .85E-06 & $3.21 E+01$ \\
\hline 5.8 & $.24 E-07$ & $4.37 E+00$ \\
\hline & 17E-08 & $4.31 E-01$ \\
\hline $6.86 E-10$ & $19 E-09$ & 5.15E-02 \\
\hline $9.14 E-11$ & $8.24 E-10$ & $6.86 E-03$ \\
\hline $0.00 E+00$ & $0.00 E+00$ & $0.00 E+00$ \\
\hline
\end{tabular}




\section{WHC-SD-WM-SAR-064, Rev. 0}

CONSERVATIVE CASE

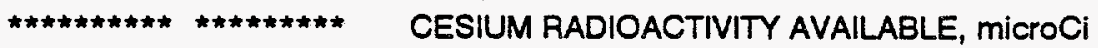

\begin{tabular}{|c|c|c|c|c|c|c|c|}
\hline Distance & & & DEPTH IN C & BUST,in, & Activity $=$ & 1200 & microCi/g \\
\hline$m$ & 0.00 & 0.005 & 0.01 & 0.05 & 0.09 & 0.13 & 0.17 \\
\hline 0.5 & $7.18 E+05$ & $7.18 E+05$ & $5.75 E+06$ & $5.75 E+06$ & $5.75 E+06$ & $5.75 E+06$ & 2.11E+06 \\
\hline 1.5 & $2.15 E+06$ & $2.15 E+06$ & $1.72 E+07$ & $1.72 E+07$ & $1.72 E+07$ & $1.72 E+07$ & $6.60 E+05$ \\
\hline 2.5 & $3.59 E+06$ & $3.59 E+06$ & 2.87E+07 & 2.87E+07 & 1.34E+07 & & \\
\hline 3.5 & $5.03 E+06$ & $5.03 E+06$ & $4.02 E+07$ & $4.02 E+07$ & & & \\
\hline 4.5 & $6.46 E+06$ & $6.46 E+06$ & 5.17E+07 & $1.51 E+07$ & & & \\
\hline 5.5 & 7.90E+06 & $7.90 E+06$ & $6.32 E+07$ & & & & \\
\hline 6.5 & $9.34 E+06$ & $9.34 E+06$ & $7.47 E+07$ & & & & \\
\hline 7.5 & $1.08 E+07$ & $1.08 E+07$ & $2.70 E+07$ & & & & \\
\hline 8.5 & $1.22 E+07$ & $9.91 E+06$ & & & & & \\
\hline 9.5 & $8.45 E+06$ & & & & & & \\
\hline 10.5 & & & & & & & \\
\hline SUM & $6.66 E+07$ & 5.59E+07 & $3.09 E+08$ & 1.07E+08 & 3.64E+07 & $2.30 E+07$ & 2.77E+06 \\
\hline
\end{tabular}


WHC-SD-WM-SAR-064, Rev. 0

APPENDIX D

PRESSURE CAPABILITY FOR DOUBLE-SHELL TANKS

D-i 
WHC-SD-WM-SAR-064, Rev. 0

This page intentionally left blank.

$D-\mathbf{i} \mathbf{i}$ 
Westinghouse WHC-SD-WM-SAR-064, Rev. 0

Internal Hanford Company

Memo

From: $\quad$ Component Stress Analysis

Phone: $\quad 376-4608$ H5-56

Date: $\quad$ March 21, 1994

Subject: APPLICABILITY OF EXISTING PRESSURE CAPABILITY ANALYSES FOR

DOUBLE-SHELL TANK SY-101 TO DOUBLE-SHELL TANKS AW-101 AND AN-103, $-104,-105$

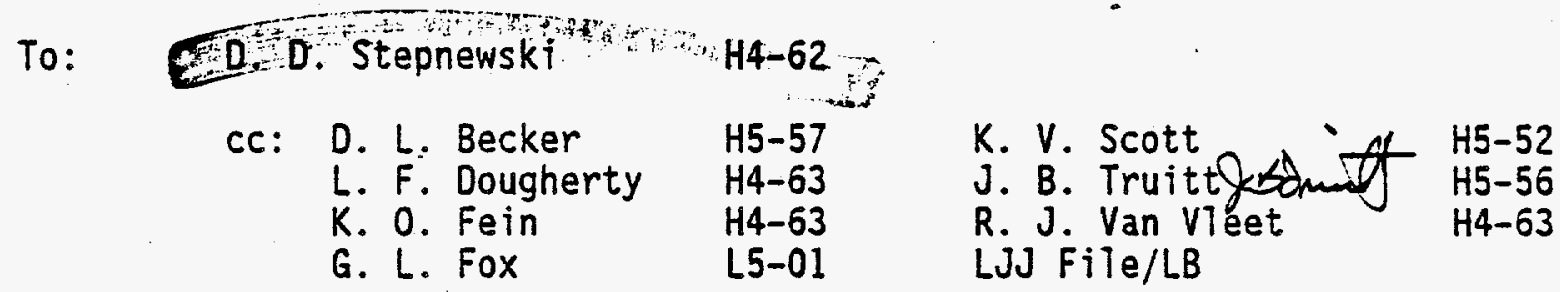

\section{OBJECTIVE}

The objective of the work on which this memo reports was to determine whether the existing analyses related to determining the internal pressure capability of double-shel1 tank (DST) 241-SY-101 (SY-101) can be applied to watch list DSTs AW-101 and AN-103, -104, -105 to determine the ir pressure capability.

\section{CONCLUSION}

The existing analyses determining the pressure capability of SY-101 are directly applicable to DSTs AW-101 and AN-103, -104, -105. Although there are some differences among these DSTs tanks, the differences are generally conservative relative to SY-101. That is, the SY-101 pressure capability can be considered as a lower bound to the pressure capability of DSTS AW-101 and $A N-103,-104,-105$.

\section{DISCUSSION}

To determine whether the analyses of SY-101 pressure capability are applicable to DSTS AW-101 and AN-103, -104, -105, we compared the geometric design details, material specifications, and design load conditions. Tables 1 and 2 summarize the tank design parameters. The tanks are geometrically similar except for some structural details. The major differences between SY-10I and the AW and AN tanks are that higher strength steel is used in the AW and AN primary and secondary tanks, higher strength concrete is specified for the AW and AN tanks, the AW and AN concrete meridional reinforcement is greater at some locations, and the AW and AN design temperatures are greater. 
Page 2

March 21, 1994

\section{GEOMETRY}

Geometrically the AW, AN, and SY tanks are very similar in construction.

Tables 3 through 5 list the civil-structural drawings reviewed for tanks SY, AW, and AN, respectively. Of particular interest is the presence of a 4-in. Schedule 40 riser penetration (pump pit drain and supernatant return) in the central pump pit of the SY-101 tank. This 4-in.-diameter riser penetrates the primary steel tank at a 6-ft radius from the center of the dome $(\mathrm{H}-2-37773)$ that al so corresponds to the location of the $3-$ to $\frac{1}{2}-$ in.thickness transition in the dome of the primary steel tank. This geometric configuration also appears in the AW (H-2-70395) and AN (H-2-71976) tanks. The $*$ to $\frac{1}{2}$-in.-thickness transition in the dome of the primary tank in combination with the 4-in. penetration has been predicted to be the location that controls the internal pressure capability of the SY-101 tank (Julyk, et al. 1991 and Julyk 1992).

\section{CONCRETE}

The concrete compressive strength specified $\left(f^{\prime}=5 \mathrm{kip} / \mathrm{in}^{2}\right.$ ) for the AW and AN tanks (a) though the AN as-built drawings $\mathrm{H}-2^{c}-71904$ and $\mathrm{H}-2-71907$ indicate that the concrete compressive strength is equal to that of $S Y$ ) is higher than that specified $\left(f^{\prime}{ }_{c}=4.5 \mathrm{kip} / \mathrm{in}^{2}\right)$ for $S Y$ (see Table 1). However, this increased strength is not significant because the internal pressure capability of the tanks is controlled by their capability to resist tensile pressure-induced loads; this resistance capability is controlled by the reinforcement in the concrete dome and the steel plate in the primary tank dome.

\section{CONCRETE REINFORCEMENT}

There are some differences between the concrete reinforcing used in the AW and AN tanks and that used in the SY-101 tank. As summarized in Table 1 , ASTM A615 Grade 60 rebar and ASTM A615 Grade 40 cross-ties are specified in SY, AW, and AN tanks. The differences are in the size and distribution of reinforcing bars used rather than in rebar material strength. To quantify these differences for comparison to $5 Y-101$, we reviewed as-built drawings and determined an equivalent rebar area ratio as defined by

$$
\begin{aligned}
& \text { Rebar equivalent } \\
& \text { area ratio relative }=\frac{\left[A_{T}\right]_{A W / A N}}{\left[A_{T}\right]_{S Y}}=\frac{\left[A_{b} n_{T}\right]_{A W / A N}}{\left[A_{b} \Omega_{T}\right]_{S Y}}=\frac{\left[A_{b} / S\right]_{A W / A N}}{\left[A_{b} / S\right]_{S Y}} \\
& \text { to } S Y \text { tanks }
\end{aligned}
$$

where

$$
\begin{aligned}
A_{T}= & A_{b} n_{T} m \\
A_{b}= & \text { cross sectional area of reinforcing bar } \\
n_{T}= & \text { total number of reinforcing bar in a given } p l a n e \\
= & 2 \pi R / s \text { for meridional bars } \\
s= & \text { center-to-center (CC) spacing between reinforcing bars } \\
& \text { measured along circumference at radius } R \\
m= & \text { number of planes containing reinforcing bars at a given section. }
\end{aligned}
$$


Tables 6 through 8 summarize the results for the concrete dome, cylindrical concrete wall, and concrete foundation, respectively. Table 9 summarizes the corresponding bar cross-section area for bar size designation number (Nilson and Winter 1991).

In the concrete dome haunch region both AW and AN have greater (by about $27 \%$ ) meridional reinforcing than SY (see Table 6 ). The AW and AN meridional and circumferential reinforcing is identical to that in $S Y$ in all other regions of the dome.

The AW meridional and circumferential reinforcing is identical to that of AN in all regions of the cylindrical concrete wall. Generally, AW and AN provide greater meridional (vertical) reinforcing in the wall than is provided in SY with one exception (see Table 7 ). The exception is just below the haunch at the 23- to 29-ft height region where the meridional reinforcing is only $80 \%$, approximately, of that in SY. The circumferential reinforcing in the cylindrical concrete walls of AW and AN is identical to that in $S Y$.

The AW meridional and circumferential reinforcing is identical to that in SY in all regions of the concrete foundation. However, there is greater meridional (radial) reinforcing in the concrete foundation in the AN tanks than in SY, as indicated in Table 8. The AN meridional and circumferential reinforcing is identical to that in SY in all other regions of the concrete foundation.

These differences in concrete reinforcing are not expected to significantly affect the internal pressure capability of the AW and AN tanks because the increased reinforcement does not occur in the region of the predicted failure, i.e., at the $\frac{*}{3}$ - to $\frac{1}{2}$-in.-thickness transition in the dome of the primary tank in combination with the 4 -in. penetration.

\section{PRIMARY AND SECONDARY STEEL}

Although the primary and secondary steel tanks for the SY, AW, and AN tanks are essentially identical geometrically (except for location of some penetrations), there are differences in the specified materials. In addition, for the SY-10I tank, at the transition of the secondary steel liner with the primary tank in the dome region, a circumferential $6-x$ 4- $x$ *-in.-angle support is welded to the secondary liner and imbedded in the dome concrete. This support configuration is not used in the AW and AN tanks.

However, of particular interest is the higher strength (minimum specified room temperature $50 \mathrm{kip} / \mathrm{in}^{2}$ yieid and $70 \mathrm{kip} / \mathrm{in}^{2}$ ultimate tensile) for the material (ASTM A537 Class 1) used in the construction of the AW and AN primary and secondary steel tanks as compared to the strength (minimum specified room temperature $35 \mathrm{kip} / \mathrm{in}^{2}$ yield and $55 \mathrm{kip} / \mathrm{in}^{2}$ ) of the material (ASTM A516 Grade 65) used in the construction of the SY-101 tank (see Table 1). This higher strength should result in a greater internal pressure capability for the AW and AN tanks when compared to SY-101. This increase in internal pressure capability may be offset by the potentially higher 
operating temperature of tanks AW and AN compared to that of SY (see Table 2). The maximum temperature in the dome region of tank AW was predicted to be $202{ }^{\circ} \mathrm{F}$ for a maximum liquid and sludge temperature of $350{ }^{\circ} \mathrm{F}$ (ARH 1976 and RHO 1978).

In addition to strength, the ductility of the primary steel tank is also of interest. Table 1 shows the room temperature minimum ductility, as measured by total elongation (TE), to be comparable for these materials. Because these material are similar low-carbon steels, their change in ductility with temperature is expected to be similar also.

The toughness of a material is a measure of its ability to absorb energy in the plastic range. One measure of toughness is taken as the total area under the stress-strain curve, which may be approximated by

$$
U_{T}=\frac{S_{y}+S_{u}}{2} T E
$$

where $S_{y}, S_{y}$, and $T E$ is the yield strength, ultimate tensile strength and total elongation, respectively, as obtained in a standard tension test. This area is an indication of the amount of work per unit volume that can be done on the material without causing it to rupture (Dieter 1976).

Table 10 summarizes strength $\left(S_{y}\right.$ and $S_{y}$ ), ductility (TE), and a toughness ratio, as compared to SY-101 properties for a range of temperatures - room temperature to a maximum temperature of $700^{\circ} \mathrm{F}$. The temperature dependence of TE is estimated from data obtained for A515 and A516, Grade 70 (NSMH), normalized to the room temperature value. The results summarized in Table 10 indicate that the AW and AN primary steel tank should exhibit a greater internal pressure capability than that predicted for the SY-101 tank.

\section{REFERENCES}

ACI, 1963, Building Code Requirements for Reinforced Concrete, ACI 318-63, American Concrete Institute, Detroit, Michigan.

ACI, 1971, Bujlding Code Requirements for Reinforced Concrete Structures, ACI 318-71, American Concrete Institute, Detroit, Michigan.

AEC, 1963, Nuclear Reactors and Earthquakes, TID-7024, U.S. Atomic Energy Commission, Division of Reactor Development, Washington, D.C.

AEC-RL, 1973, Specification for Primary and Secondary Steel Tanks Project B-10I 241-5Y Tank Farm, B-101-C1, Automation Industries, Inc., Vitro Engineering Division, Richland, Washington, prepared for U.S. Atomic Energy Commission Richland Field Office, Richland, Washington. 
WHC-SD-WM-SAR-064, Rev. 0

D. D. Stepnewski

Page 5

March 21, 1994

AEC-RL, 1974a, Specification for Excavation and Tank Foundations 241-SY Tank Farm Project B-101, B-101-C2, Automation Industries, Inc., Vitro Engineering Division, Richland, Washington, prepared for U.S. Atomic Energy Commission Richland Field Office, Richland, Washington.

AEC-RL, 1974b, Construction Specification for Completion of Tanks 241=SY Tank Farm Project B-101, B-101-C3, Automation Industries, Inc., Vitro Engineering Division, Richland, Washington, prepared for U.S. Atomic Energy Commission Richland Field Office, Richland, Washington.

ASME, 1971, ASME Boiler and Pressure Vessel Code, Section III, Division I, 1971 Edition and Addenda through 1973, American Society of Mechanical Engineers, New York, New York.

ASME, 1974a, ASME Boiler and Pressure Vessel Code, Section VIII, Division 2, Alternate Rules for Pressure Vessels, 1974 Edition and Addenda through Summer 19.75, American Society of Mechanical Engineers, New York, New York.

ASME, 1974b, ASME Boiler and Pressure Vessel Code, Section VIII, Division 2, Alternate Rules for Pressure Vessels, 1974 Edition and Addenda through Summer 1976, American Society of Mechanical Engineers, New York, New York.

ASME, 1992, ASME Boiler and Pressure Vessel Code, Section II, Materials, Part D - Properties, American Society of Mechanical Engineers, New York, New York.

ASTM, 1989, "Volume 01.04 - Steel-Structural, Reinforcing, Pressure Vessel, Railway," 1989 Annual Book of ASTM Standards, Section 1 - Iron and Steel Products, American Society for Testing and Materials, Philadelphia, Pennsylvania.

ARH, 1974, Analysis of Underground Waste Storage Tanks 241-SY at Hanford, Washington, ARH-R-172, URS/John A. Blume and Associates, Engineers, prepared for Atlantic Richfield Hanford Company, Richland Washington.

ARH, 1976, Analysis of Underground Waste Storage Tanks 241-AW at Hanford, Washington, ARH-R-219, URS/John A. Blume and Associates, Engineers, prepared for Vitro Engineering, Richland Washington.

Dieter, G. E., 1976, Mechanical Metallurgy, 2nd edition, McGraw-Hill Book Company, New York, New York.

DOE-RL, 1973, "Standard Arch-Civil Design Criteria, Design Loads for Facilities," Hanford Plant Standards, SDS-4.1, Rev. 6, U.S. Department of Energy, Richland Operations Office, Richland, Washington.

ERDA-RL, 1976a, Construction Specification for the 241-AW Tank Farm Project B-120 Foundations, B-120-C3, Vitro Engineering Corporation, Richland, Washington, prepared for U.S. Energy Research and Development Administration Richland Field Office, Richland, Washington. 
WHC-SD-WM-SAR-064, Rev. 0

D. D. Stepnewski

Page 6

CSA:LJJ :ggb: $94 / 2$

March 21, 1994

ERDA-RL, 1976b, Construction Specification for Primary and Secondary Steel Tanks Project B-120 241-AW Tank Farm, B-120-C4, Vitro Engineering Corporation, Richland, Washington, prepared for U.S. Energy Research and Development Administration Richland Field Office, Richland, Washington.

ERDA-RL, 1976c, Design Specification for Primary and Secondary Steel Tanks Project B-120 241-AW Tank Farm, B-120-D1, Vitro Engineering Corporation, Richland, Washington, prepared for U.S. Energy Research and Development Administration Richland Field Office, Richland, Washington.

ERDA-RL, 1977a, Construction Specification for the 241-AW Tank Farm Project B-120 Concrete She17, B-120-C5, Vitro Engineering Corporation, Richland, Washington, prepared for U.S. Energy Research and Development Administration Richland Field Office, Richland, Washington.

ERDA-RL, 1977b, Construction Specification for the 241-AN Tank Farm Site Preparation Project B-130, B-130-C1, Vitro Engineering Corporation, Richland, Washington, prepared for U.S. Energy Research and Development Administration Richland Field Office, Richland, Washington.

ERDA-RL, 1977c; Construction Specification for the 241-AN Tank Farm Project B-130 Foundation, B-130-C3, Vitro Engineering Corporation, Richland, Washington, prepared for U.S. Energy Research and Development Administration Richland Field Office, Richland, Washington.

ERDA-RL, 1978a, Construction Specification for Primary and Secondary Steel Tanks Project B-130 241-AN Tank Farm, B-130-C4, Vitro Engineering Corporation, Richland, Washington, prepared for U.S. Energy Research and Development Administration Richland Field Office, Richland, Washington.

ERDA-RL, 1978b, Construction Specification for the 241-AN Tank Farm Project B-130 Concrete She 17, B-130-C5, Vitro Engineering Corporation, Richland, Washington, prepared for U.S. Energy Research and Development Administration Richland Field Office, Richland, Washington.

ERDA-RL, 1978c, Design Specification for Primary and Secondary Steel Tanks Project B-130 241-AN Tank Farm, B-130-D1, Vitro Engineering Corporation, Richland, Washington, prepared for U.S. Energy Research and Development Administration Richland Field Office, Richland, Washington.

Julyk, L. J., et al., 1991, Structural Integrity Evaluation of Double-Shell Waste Tank 241-5Y-101 Under a Postulated Hydrogen Burn, WHC-SD-WM-TI-465, Rev. 0, Westinghouse Hanford Company, Richland, Washington. 
Julyk, L. J., 1992, Reassessment of 241-SY-101 Local Discontinuity Strains for Combination Effect of Thickness Transition and 4-inch Penetration in Dome, Appendix C, WHC-EP-0578, Westinghouse Hanford Company, Richland, Washington.

Nilson, A. H., and G. Winter, 1991, Design of Concrete Structures, 11th edition, McGraw-Hill, Inc., New York, New York.

NSMH, Nuclear Systems Materials Handbook, TID 26666, Oak Ridge National Laboratory, Oak Ridge, Tennessee.

RHO, 1978, Additional Analyses of Underground Waste Storage Tanks 241-AW, Hanford, Washington, RHO-C-17, URS/John A. Blume and Associates, Engineers, prepared for Vitro Engineering, Richland Washington.

RHO, 1981a, A Comprehensive Summary of the Analysis of the 241-AN Underground Waste Storage Tanks, Hanford, Washington, RHO-C-60, URS/John A. Blume and Associates, Engineers, prepared for Vitro Engineering, Richland Washington.

RHO, 1981b, Additional Analyses of Underground Waste Storage Tanks 241-5Y, Hanford, Washington, RHO-C-59, URS/John A. Blume and Associates, Engineers, prepared for Vitro Engineering, Richland Washington.

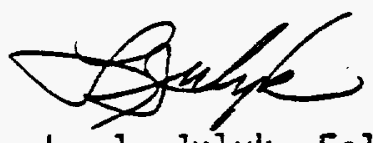

L. J. Julyk, Fellow Engineer

Component Stress Analysis

$g g b$

Attachments 
Table 1. Summary of Hanford Double-Shell Tank Design Parameters for Tanks SY, AW, and AN.

\begin{tabular}{|c|c|c|c|c|c|c|c|c|c|c|c|c|c|c|c|c|}
\hline \multirow{5}{*}{$\begin{array}{l}\text { Tounk } \\
\text { form } \\
241 \text { - }\end{array}$} & \multirow{5}{*}{$\begin{array}{l}\text { Mumbor } \\
\text { of } \\
\text { Tonks }\end{array}$} & \multirow{5}{*}{$\begin{array}{l}\text { Conot. } \\
\text { Dater } \\
\text { Steur } \\
\text { End }\end{array}$} & \multirow{5}{*}{$\begin{array}{l}\text { Mentord } \\
\text { Constructon } \\
\text { Sposthestion }\end{array}$} & \multicolumn{7}{|c|}{ 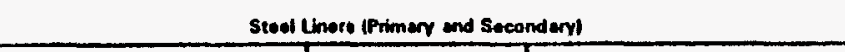 } & \multirow{2}{*}{\multicolumn{3}{|c|}{$\frac{\text { Conarate }}{\text { Speodflecention }}$}} & \multicolumn{3}{|c|}{ Rechlorcemement Stoos } \\
\hline & & & & \multicolumn{2}{|c|}{ Dosion Code } & \multirow{2}{*}{\multicolumn{3}{|c|}{$\frac{\text { Stroed Spose. }}{\text { ASME Mhinumum ' }}$}} & \multicolumn{2}{|c|}{ Wotos } & & & & \multirow{4}{*}{$\begin{array}{l}\text { Rabu } \\
\text { (Astu) }\end{array}$} & \multirow{4}{*}{ 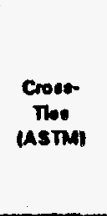 } & \multirow{4}{*}{ Wolde } \\
\hline & & & & \multirow{3}{*}{$\begin{array}{l}\text { Pothary } \\
\text { Uhaer }\end{array}$} & \multirow{3}{*}{ Socondery } & & & & \multirow{3}{*}{ Proc. } & \multirow{3}{*}{ Quas. } & \multicolumn{3}{|c|}{ 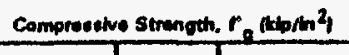 } & & & \\
\hline & & & & & & \multicolumn{2}{|c|}{ 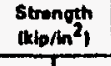 } & $\begin{array}{l}\operatorname{sintm} \\
|x|\end{array}$ & & & \multirow{2}{*}{ Domo } & \multirow{2}{*}{ wall } & \multirow{2}{*}{ roundertion } & & & \\
\hline & & & & & & 3. & $s_{v}$ & $\pi$ & & & & & & & & \\
\hline \multirow[t]{2}{*}{ sr } & \multirow[t]{2}{*}{ 了 } & \multirow[t]{2}{*}{$\begin{array}{l}1994 \\
1870\end{array}$} & \multirow{2}{*}{ 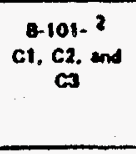 } & \multirow{2}{*}{ 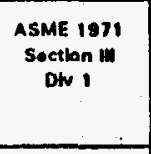 } & \multirow{2}{*}{$\begin{array}{l}\text { ASMEE } 1971 \\
\text { Soction it } \\
\text { DN I }\end{array}$} & \multicolumn{3}{|c|}{ A618-72. Grode os } & \multirow[t]{2}{*}{ HPs-230.W } & \multirow{2}{*}{ 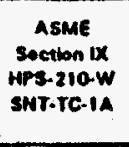 } & \multicolumn{3}{|c|}{ 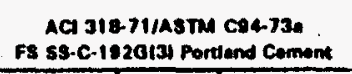 } & \multirow[t]{2}{*}{$\begin{array}{ll}A B 15-12 \\
a, \infty 0\end{array}$} & \multirow[t]{2}{*}{$\begin{array}{l}\text { Aats-12 } \\
\text { as } 40\end{array}$} & \multirow[t]{2}{*}{$\begin{array}{l}\text { HPS- 220.W } \\
\text { HPS-200.W }\end{array}$} \\
\hline & & & & & & 36 & os & 23310 & & & 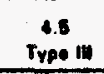 & 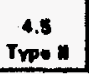 & $\begin{array}{l}4.8^{3} \\
\text { Trpov }\end{array}$ & & & \\
\hline Aw & - & $\begin{array}{l}1970 \\
1080\end{array}$ & $\begin{array}{l}\text { Q120.4 } \\
\text { co. c4. c8. }\end{array}$ & $\begin{array}{l}\text { ASME } 1974 . \\
\text { Soction Vin }\end{array}$ & $\begin{array}{l}\text { ASME } 1074 . \\
\text { Soction VVIM }\end{array}$ & A637 & 7.74. & alo.e 1 & $\begin{array}{l}\text { MPS. 230.W } \\
\text { AWs 01.1.17 }\end{array}$ & $\begin{array}{l}\text { ASME } \\
\text { Sostion iX }\end{array}$ & $\begin{array}{l}\mathrm{ACC} 3 \mathrm{31} \\
\mathrm{Astm} \mathrm{CI}\end{array}$ & $\begin{array}{l}\text { linsmin } \\
\text { reat portt }\end{array}$ & 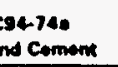 & $\begin{array}{l}A 618.780 \\
\text { ar } \infty 00\end{array}$ & $\begin{array}{l}\text { Ae15.700 } \\
0.40\end{array}$ & $\begin{array}{l}\text { AWs D12.1.75 } \\
\text { MPS.220-W }\end{array}$ \\
\hline & & & & & & so & 10 & 22218 & & & Typen..1 & Typon & $\begin{array}{l}4.5 \\
\text { inpo n. } \\
\end{array}$ & & & \\
\hline AN & T & $\begin{array}{l}1980 \\
1881\end{array}$ & $\begin{array}{l}\text { o-130. } \\
\text { ci. co. ce. }\end{array}$ & $\begin{array}{l}\text { AsMe } 1974 \text { Ad } \\
\text { section Vim }\end{array}$ & $\begin{array}{l}\text { ASME IBitb } \\
\text { Soetion VIII }\end{array}$ & & .7.78. & Aavo 1 & $\begin{array}{l}\text { MPs.120.W } \\
\text { AWs 01.1.n }\end{array}$ & 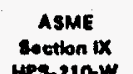 & $\begin{array}{rl}A C t & 31 \\
\text { Astm CI } & \\
\end{array}$ & $\begin{array}{l}71 / 1 \text { astum } \\
\text {-70a Port } \\
\end{array}$ & nd comont & $\underset{00+\infty}{A 018-78}$ & $\begin{array}{l}\text { Ae15. } \\
\text { ait } 40\end{array}$ & $\begin{array}{l}\text { AWs } 012.11 .78 \\
\text { HPs. 220-W }\end{array}$ \\
\hline & & & & & & so & no & 22210 & & & $\begin{array}{l}4.0^{\circ} \\
\text { iveen: }\end{array}$ & $\begin{array}{l}4 . x^{\circ} \\
7 y 00010\end{array}$ & $\begin{array}{l}4.5 \\
\text { Type } \\
\end{array}$ & & & \\
\hline
\end{tabular}

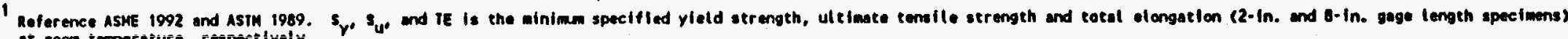

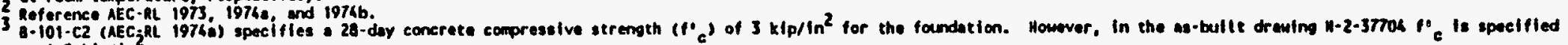
$23.5 \mathrm{k} / \mathrm{p} / \mathrm{in}^{2}$.

Reference EROA.RL 1976s, 1976b, 19776, and 1976c.

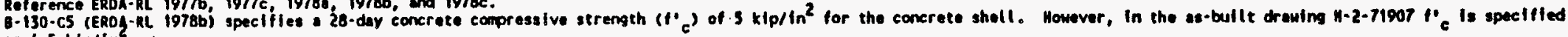

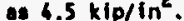


Table 2. Summary of Hanford Double-Shell Tank Design-Load Parameters for Tanks SY, AW, and AN.

\begin{tabular}{|c|c|c|c|c|c|c|c|c|c|c|c|c|}
\hline \multirow{4}{*}{$\begin{array}{l}\text { Tank } \\
\text { Farm } \\
241\end{array}$} & \multirow{4}{*}{$\begin{array}{c}\text { Design } \\
\text { Lifo } \\
\text { (years) }\end{array}$} & \multirow{4}{*}{$\begin{array}{c}\text { Reference } \\
\text { Analysis } \\
\text { Document }\end{array}$} & \multicolumn{10}{|c|}{ Design Load Conditions } \\
\hline & & & \multirow{3}{*}{$\begin{array}{l}\text { Seismic } \\
\text { DBE } 1\end{array}$} & \multicolumn{5}{|c|}{ Dome Loading } & \multicolumn{4}{|c|}{ Waste } \\
\hline & & & & \multirow{2}{*}{$\begin{array}{l}\text { Soil } \\
\text { Overburden } \\
\text { at Crown } \\
\text { (ft) }\end{array}$} & \multirow{2}{*}{$\begin{array}{l}\text { Livo } \\
\text { Load } \\
\left.\text { (Ibt/ft }{ }^{2}\right)\end{array}$} & \multirow{2}{*}{$\begin{array}{c}\text { Concentrated } \\
\text { Load } \\
\text { (tons) }\end{array}$} & \multicolumn{2}{|c|}{ Vapor Pressure (in. wator) } & \multirow{2}{*}{$\begin{array}{l}\text { Capacity } \\
\text { (gall) }\end{array}$} & \multirow{2}{*}{$\begin{array}{c}\text { Maximum } \\
\text { Specific } \\
\text { Gravity }\end{array}$} & \multicolumn{2}{|c|}{$\begin{array}{c}\text { Maximum Temperature } \\
\left({ }^{\circ} \mathrm{F}\right)\end{array}$} \\
\hline & & & & & & & Above liquid & Annulus & & & Liquid \& Sludge & Vapor \\
\hline sy & & $\begin{array}{l}\text { ARH } 1974 \\
\text { RHO } 1981 \\
\end{array}$ & $\begin{array}{c}\mathrm{r} 1 \mathrm{D}-7024^{2} \\
0.26 \mathrm{~g} \\
\end{array}$ & $\begin{array}{c}6.6 \\
\left(120 \mathrm{ibt} / \mathrm{tt}^{3}\right) \\
\end{array}$ & 40 & 60 & $-6 /+60$ & +12 & 1.144 .000 & 1.7 & 260 & 220 \\
\hline AW & 60 & $\begin{array}{l}\text { ARH } 1976 \\
\text { RHO } 1978\end{array}$ & $\begin{array}{c}\text { TID-7024 } \\
\text { HPS SDC-4.1 } \\
0.26 g \\
\end{array}$ & $\begin{array}{c}6.6 \\
\left(110 \mathrm{Ibt} / \mathrm{tt}^{3}\right)\end{array}$ & 40 & 60 & $-6 /+60$ & $-6 / 1 \mathrm{~atm}$ & $1,144.000$ & 2.0 & 350 & \\
\hline AN & $\begin{array}{r}60 \\
.\end{array}$ & RHO 1978 & $\begin{array}{c}\text { TID-7024 } \\
\text { HPS SDC-4.1 } \\
0.26 g\end{array}$ & $\begin{array}{c}6.6 \\
\left(110 \mathrm{lbt} / \mathrm{t}^{3}\right)\end{array}$ & 40 & 50 & $-6 /+60$ & $.6 / 1 \mathrm{~atm}$ & 1.144 .000 & 2.0 & 350 & \\
\hline
\end{tabular}

$\begin{array}{ll}1 & \mathrm{DBE}=\text { Design Bas is Earthquake. } \\ & 2 \text { Reference AEC } 1963 .\end{array}$

í 3 Reference DOE-RL 1973. 
Table 3. 241-SY Tank Farm Civil-Structural Drawing List.

\begin{tabular}{|c|c|c|c|}
\hline $\begin{array}{l}\text { Drawing } \\
\text { No. }\end{array}$ & Rev. & Iitle & Comment \\
\hline$H-2-37700$ & 4 & Drawing Index & \\
\hline H-2-37701 & 3 & Civil Plot Plan 241-sY Tank Farm & \\
\hline H-2-37702 & 1 & Civil Excavation Plan for Ianks $241-5 Y-101,102,103$ & \\
\hline H-2-37704 & 2 & Structural Concrete Tank Foundation Plan \&etails Tank 241-SY-101, 102, \& 103 & $f_{c}=4.5 \mathrm{kip} / \mathrm{in}^{2}$ \\
\hline$H-2-37705$ & 2 & Structural Insulating Concrete Plan \& Details & \\
\hline$H-2-37706$ & 2 & Concrete Iank Section \& Haunch Reinforcement & $\begin{array}{l}\text { fo }=4.5 \mathrm{kip} / \mathrm{in}^{2} \text {. Bar splices and bends } \\
\text { pef Aci } 318-71 \text {. }\end{array}$ \\
\hline$H-2-37707$ & 1 & Concrete Dome Reinforcement Plan \& Details & $\begin{array}{l}\text { Radial circumferential reinforcement } \\
\text { interrupted by penetrations shall be } \\
\text { replaced by an equivalent area of reinf. } \\
\text { Replacement reinf. shall have a min. lap of } \\
64 \text { diameters in dome haunch area } 48 \\
\text { diameters elsewhere. }\end{array}$ \\
\hline H-2-37708 & 1 & Concrete Haunch Reinforcement at Annul us Access & \\
\hline$H-2-37711$ & 1 & Structural Punp Pits Plan, Sections, and Details 241-sY-01A, 02A, \& $03 \mathrm{~A}$ & - \\
\hline$H-2-37718$ & 1. & Structural Riser Enclosure Plan \& Details & \\
\hline$H-2-37751$ & $\underline{2}$ & Instrumentation Concrete foundation Tank 241-sy-101, 102, \& 103 Plan \& Details & \\
\hline H-2-37752 & 1 & Instrumentation Taik Annulus Leak Detection System Plan \& Details & \\
\hline H-2-37767. & $\underline{2}$ & Engineering Flow Diagram 241-sY Tank farm Tank 101 & \\
\hline H-2-37772 & $\underline{2}$ & Iank Cross Section 241-sy Iank farm & Primary and secondary steel liner details. \\
\hline$H-2-37773$ & 7 & Plan Penetration \& Schedule 241-SY Tank Farm & $\begin{array}{l}\text { 4-in. Sched } 40 \text { Pump Pit Drain \& SN Return } \\
\text { shown at } 6-f t \text { radius near } \% \text { - to- } y \text {-in. plate } \\
\text { thk. transition in dome. }\end{array}$ \\
\hline$H-2-37774$ & 1 & Miscellaneous Sections \& Details & \\
\hline H-2-37775 & 4 & Miscellaneous Sections \& Details & \\
\hline $\mathrm{H}-2-37776$ & 4 & Iank Penetration \& Riser Details 241-SY Iank Farm & \\
\hline $\mathrm{H}-2-37778$ & 4 & Piping Plan 241-sy Tank Farm & \\
\hline $\mathrm{H}-2-37782$ & 5 & Jumper Arrangement Pump Pit $241-s Y-01 A, 02 A, \& 03 \mathrm{~A}$ & \\
\hline
\end{tabular}


Table 3. 241-SY Tank Farm Civil-Structural Drawing List (Cont'd).

\begin{tabular}{|c|c|c|c|}
\hline $\begin{array}{l}\text { Drawing } \\
\text { No. }\end{array}$ & Rev. & Title & Comment \\
\hline H-2-37783 & 3 & Piping Plan \& Details Pump Pit 241-sy-01A, 02A, \& 03A & \\
\hline $\mathrm{H}-2-37792$ & 1 & Tank Riser Plug Details & \\
\hline$H-2-37801$ & 3 & Piping Plan Tank 101 & \\
\hline H-2-37821 & 1 & rank Reference Information 241-SY Tank Farm & Primary \& secondary tank weld details. \\
\hline $\mathrm{H}-2-37822$ & 1 & Iank Reference Information 241-sy Jank Farm & Primary tank bottom plate layout. \\
\hline H-2-37824 & 1 & Iank Reference Information 241-SY Tank Farm & Primary tank bottom knuckle weld details. \\
\hline$H-2-37825$ & 1 & Iank Reference Information 241-sy Tank Farm & Secondary tank bottom knuckle weld details. \\
\hline H-2-37841 & 1 & Tank Reference Information 241-sY Iank Farm & Roof shell anchor stud locations. \\
\hline $\mathrm{H}-2-37842$ & 1 & Tank Reference Information 241-sY Tank farm & $\begin{array}{l}\text { Primary secondary tank roof \& knuckle } \\
\text { layout and weld details. }\end{array}$ \\
\hline
\end{tabular}

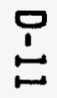


Table 4. 241-AW Tank Farm Civil-Structural Drawing List.

\begin{tabular}{|c|c|c|c|}
\hline $\begin{array}{c}\text { Drawing } \\
\text { No. }\end{array}$ & Rev. & ritle & Comment \\
\hline $\mathrm{H}-2-70300$ & 4 & Drawing Index & \\
\hline H-2-70302 & 5 & Civil Plot Plan 241-AH Jank Farm & \\
\hline H-2-70303 & 2 & Civil Excavation Plan & \\
\hline$H-2-70304$ & 1 & Structural Insulating Concrete Plan \& Details & \\
\hline$H-2-70305$ & 3 & Structural Concrete Iank foundation Plan \& Details & $f{ }_{c}=4.5 \mathrm{kip} / \mathrm{in}^{2}$ \\
\hline $\mathrm{H}-2-70306$ & 1 & Concrete Iank Section \& Haunch Reinforcement & $t_{c}=5 \mathrm{kip} / \mathrm{in}^{2}$. \\
\hline$H-2-70308$ & 1 & Concrete Dome Reinforcement Plan \& Details & $\begin{array}{l}\text { Radial \& circumferential reinforcement } \\
\text { interrupted by penetrations shatl be } \\
\text { replaced by an equivalent area of reinf. } \\
\text { Replacement reinf. shall have a min. lap of } \\
64 \text { diameters in haunch area and } 48 \text { diameters } \\
\text { elsewhere. }\end{array}$ \\
\hline H-2-70309 & 1 & Concrete Haunch Reinforcement at Annulus Access & \\
\hline H-2.70310 & 3 & Structural Leak Detection Pits Plans, Sections and Details 241-AW-01C thru 06C & \\
\hline$H-2-70311$ & $\underline{2}$ & Structural Annulus Pump Pits Plan, Sections, and Detalls 241-AW-018 thru 06B & \\
\hline$H-2-70312$ & 4 & Structural Central Pump Pits Plans, Section \& Details 241-AH-01A thru 06A & \\
\hline H-2-70316 & 4 & Structura! Section Detaits & \\
\hline $\mathrm{H}-2-70343$ & 1 & $\begin{array}{l}\text { Instrumentation Concrete foundation Tank 241-AH-101, 102, 103, 104, 105, \& } 106 \\
\text { Plan \& Details }\end{array}$ & \\
\hline $\mathrm{H}-2-70387$ & 8 & Engineering Flow Diagram 241-AW Iank Farm & \\
\hline H-2-70394 & 2 & Iank Cross Section 241-AW Tanks & Primary and secondary steel liner details. \\
\hline H-2-70395 & 3 & Plan rank Penetrations 241-AW ranks & $\begin{array}{l}\text { 4-in. Sched } 40 \text { Supernatant Return shown at } \\
6-f t \text { radius near } k-t o-k \text {-in. plate thk. } \\
\text { transition in dome. }\end{array}$ \\
\hline H-2-70396 & 2 & Tank Penetration \& Riser Details 241-AH Tanks & \\
\hline$H-2-70420$ & 1 & rank Riser \& Plug Details & \\
\hline H-2-70429 & 5 & Jumper Arrangement Central Pump Pit 241-AW-01A thru 06A & \\
\hline$H-2-77109$ & 1 & Piping Sections \& Details & \\
\hline
\end{tabular}


Table 5. 241-AN Tank Farm Civil-Structural Drawing List.

\begin{tabular}{|c|c|c|c|}
\hline $\begin{array}{c}\text { Drawing } \\
\text { No. }\end{array}$ & Rev. & Title & Comment \\
\hline$H-2-71104$ & 1 & civil Leak Detection Drain and Sump Plans and Details & $\dot{-}$ \\
\hline$H-2-71900$ & 3 & Drawing Index & \\
\hline$H-2-71903$ & 2 & Civil Excavation Plan 241-AN Tank farm & \\
\hline $\mathrm{H}-2-71904$ & 3 & Structural Concrete rank Foundation Plan \& Details & $f_{0}=4.5 \mathrm{kip} / \mathrm{in}^{2}$ \\
\hline$H-2-71906$ & 1 & Structural Insulating Concrete Plan \& Details & \\
\hline H-2-71907 & 1 & Concrete Tank Section \& Haunch Reinforcement & $f_{c}=4.5 \mathrm{kip} / \mathrm{in}^{2}$. \\
\hline$H-2-71908$ & 1 & Concrete Dome Reinforcement Plan \& Details & $\begin{array}{l}\text { Radial \& circumferential reinforcement } \\
\text { interrupted by penetrations shall be } \\
\text { replaced by an equivalent area of reinf. } \\
\text { Replacement reinf. shall have a min. lap of } \\
\text { o4 diameters in haunch area and } 48 \text { di ameters } \\
\text { elsewhere. }\end{array}$ \\
\hline$H-2-71909$ & 1 & Concrete Haunch Reinforcement at Annulus Access & \\
\hline$H \cdot 2-71910$ & 3 & Structural Leak Detection Pits 241-AN-01C thru 07C & \\
\hline $\mathrm{H}-2-71911$ & 3 & Structural Annulus Pump Pits 241-AN-01B thru 078 & \\
\hline H-2-71912 & 3 & Structural Central Pump Pits 241-AN-01A thru 07A & \\
\hline$H-2-71915$ & 2 & Structural Concrete Pad \& Misc. \& Detaits & \\
\hline$H-2-71940$ & 1 & $\begin{array}{l}\text { Instrumentation Concrete foundation Tank 241-AN-101, 102, 103, 104, 105, } 106 \\
\text { Plan \& Details }\end{array}$ & \\
\hline H-2-71975 & 2 & Tank Cross Section 241-AH Tanks & Primary and secondary steel liner details. \\
\hline$H-2-71976$ & 5 & Plan Jank Penetrations 241-AM Janks & $\begin{array}{l}\text { 4-in. Sched } 40 \text { Supernatant Return shown at } \\
6-f t \text { radius near } k \text {-to- } \psi \text {-in. plate thk. } \\
\text { transition in dome. }\end{array}$ \\
\hline 11-2-71977 & 3 & Tank Penetration Riser Details 241 -AN Tanks & \\
\hline $\mathrm{H}-2-71978$ & 5 & Engineering Flow Diagram 241-AN Tank Farm & \\
\hline H-2-71986 & 6 & Piping $P$ lan 241-AM Tank farm & \\
\hline $\mathrm{H}-2-72010$ & 4 & Jumper Arrangement Central Pump Pit 241-AN-01A thru 07A & \\
\hline SK-2-43262 & 0 & Civil Plot Plan 241-AN Tank farm & \\
\hline
\end{tabular}


Table 6. AW and AN Concrete-Dome Rebar Equivalent-Area Ratio Relative to SY.

\begin{tabular}{|c|c|c|c|c|c|c|c|c|}
\hline \multirow{3}{*}{ Radius } & \multirow{3}{*}{ Loc. } & \multicolumn{6}{|c|}{ Distribution } & \multirow{3}{*}{$\begin{array}{c}\text { AW \& AN } \\
\text { Rebar } \\
\text { Equivalent } \\
\text { Area Ratio } \\
\text { Relative } \\
\text { to SY }\end{array}$} \\
\hline & & \multicolumn{3}{|c|}{ SY $(H-2-37707)$} & \multicolumn{3}{|c|}{$\begin{array}{l}\text { AW }(\mathrm{H}-2-70308) \\
\text { AN }(\mathrm{H}-2-71908)\end{array}$} & \\
\hline & & $\begin{array}{l}\text { Bar } \\
\text { Size } \\
\end{array}$ & $\begin{array}{l}\text { Area } \\
\left(i^{2}\right)\end{array}$ & $\begin{array}{c}C C \\
(\text { in. })\end{array}$ & $\begin{array}{l}\text { Bar } \\
\text { Size } \\
\end{array}$ & $\begin{array}{l}\text { Area } \\
\left(\text { in }^{2}\right)\end{array}$ & $\begin{array}{c}C C \\
\text { (in.) }\end{array}$ & \\
\hline $24^{\prime}-0^{\prime \prime}-41^{\prime}-3 \frac{1}{2} "$ & $\mathrm{~T} / \mathrm{B}$ & $\# 8$ & 0.79 & 6 & $\# 9$ & 1.00 & 6 & 1.27 \\
\hline
\end{tabular}

Circumferential Rebar

Note that AW rebar distribution in concrete dome is the same as in AK.

$T / B=T o p$ and bot tom of concrete dome

$C C=$ Center-to-center circumferential spacing between rebar at maximum radius indicated.

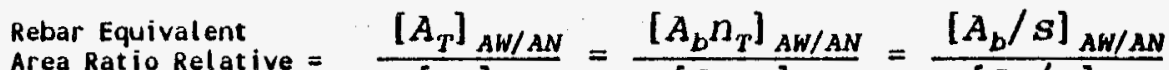

Area Ratio Relative
to $S Y$ Tanks

${ }_{A_{b}^{A}}^{A}={ }_{C}^{A} P_{0}^{n} I^{m}$ sectional area of reinforcing bar

$n_{\mathrm{T}}=$ total number of reinforcing bar in a given plane

$=2 \pi R / s$ for meridional bars

= center-to-center (CC) spacing between reinforcing bars measured

atong circunference at radius $R$

$m$ = number of planes containing reinforcing bars. 
Table 7. AW and AN Cylindrical-Concrete-Wall Rebar Equivalent-Area Ratio Relative to SY.

\begin{tabular}{|c|c|c|c|c|c|c|c|c|}
\hline \multirow{4}{*}{ Height } & \multirow{4}{*}{ Loc. } & \multirow{2}{*}{\multicolumn{6}{|c|}{ Distribution }} & \multirow{4}{*}{$\begin{array}{c}\text { AW \& AN } \\
\text { Rebar } \\
\text { Equivalent } \\
\text { Area Ratio } \\
\text { Relative } \\
\text { to SY }\end{array}$} \\
\hline & & & & & & & & \\
\hline & & \multicolumn{3}{|c|}{ SY $(H-2-37706)$} & \multicolumn{3}{|c|}{$\begin{array}{l}\text { AW }(\mathrm{H}-2-70307) \\
\text { AN }(\mathrm{H}-2-71907)\end{array}$} & \\
\hline & & $\begin{array}{l}\text { Bar } \\
\text { Size } \\
\end{array}$ & $\begin{array}{l}\text { Area } \\
\left(i^{2}\right)\end{array}$ & $\begin{array}{c}C C \\
(\text { in. })\end{array}$ & $\begin{array}{l}\text { Bar } \\
\text { Size } \\
\end{array}$ & $\begin{array}{l}\text { Area } \\
\left(i^{2}\right)\end{array}$ & $\begin{array}{c}c c \\
(\text { in. })\end{array}$ & \\
\hline $0^{\prime}-10^{\prime}$ & EF & \#6 & 0.44 & 12 & $\# 10$ & 1.27 & 24 & 1.44 \\
\hline $10^{\prime}-23^{\prime}$ & $\mathrm{EF}$ & $\# 6$ & 0.44 & 9 & $\# 10$ & 1.27 & 24 & 1.08 \\
\hline $23^{\prime}-29^{\prime}$ & EF & $\# 8$ & 0.79 & 12 & $\# 10$ & 1.27 & 24 & 0.80 \\
\hline $29^{\prime}-38^{\prime}$ & EF & $\# 8$ & 0.79 & 6 & $\# 9$ & 1.00 & 6 & 1.27 \\
\hline $29^{\prime}-38^{\prime}$ & OF & $\# 6$ & 0.44 & 6 & $\# 8$ & 0.79 & 6 & 1.80 \\
\hline
\end{tabular}

Circumferential Rebar

\section{All locations}

Note that AH rebar distribution in concrete wall is the same as in AN.

EF = Each face of concrete wall.

$c c=$ Center-to-center distance between rebar.

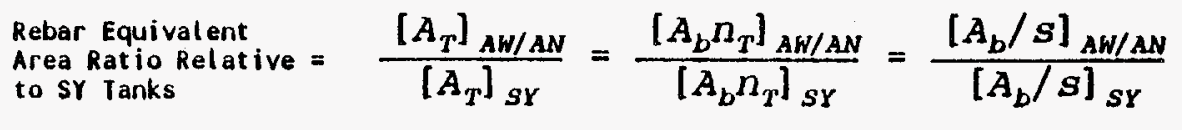

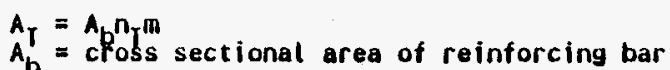

$\mathrm{A}_{\mathrm{b}}=$ total nuber of reinforcing bar in a given plane

$=2 \pi R / s$ for meridional bars

$s=$ center-to-center (CC) spacing between reinforcing bars measured

along circumference at radius $R$

$m=$ number of planes containing reinforcing bars. 
Table 8. AW and AN Concrete-Foundation Rebar Equivalent-Area Ratio Relative to SY.

Meridional (Radial) Rebar

\begin{tabular}{|c|c|c|c|c|c|c|c|c|}
\hline \multirow{3}{*}{ Radius } & \multirow{3}{*}{ Loc. } & \multicolumn{6}{|c|}{ Distribution } & \multirow{3}{*}{$\begin{array}{l}\text { AN Rebar } \\
\text { Equivalent } \\
\text { Area Ratio } \\
\text { Relative } \\
\text { to SY }\end{array}$} \\
\hline & & \multicolumn{3}{|c|}{$\begin{array}{l}\text { SY }(\mathrm{H}-2-37704) \\
\text { AW }(\mathrm{H}-2-70305)\end{array}$} & \multicolumn{3}{|c|}{ AN $(H-2-71904)$} & \\
\hline & & $\begin{array}{l}\text { Bar } \\
\text { Size } \\
\end{array}$ & $\begin{array}{l}\text { Area } \\
\left(i^{2}\right)\end{array}$ & $\begin{array}{c}C C \\
\text { (in.) }\end{array}$ & $\begin{array}{l}\text { Bar } \\
\text { Size } \\
\end{array}$ & $\begin{array}{l}\text { Area } \\
\left(\text { in }^{2}\right)\end{array}$ & $\begin{array}{c}C C \\
\text { (in.) }\end{array}$ & \\
\hline $28^{\prime}-0^{\prime \prime}-36^{\prime}-3^{\prime \prime}$ & B & $\# 7$ & 0.60 & 6 & $\# 8$ & 0.79 & $7 \frac{3}{4}$ & 1.02 \\
\hline $36^{\prime}-3^{\prime \prime}-44^{\prime}-6^{\prime \prime}$ & B & $\# 7$ & 0.60 & $4 \frac{1}{2}$ & $\# 10$ & 1.27 & $8 \frac{3}{1}$ & 1.09 \\
\hline $14^{\prime}-0^{\prime \prime}-28^{\prime}-0^{\prime \prime}$ & $\mathrm{I}$ & $\# 5$ & 0.31 & 12 & $\# 6$ & 0.44 & 12 & 1.42 \\
\hline $28^{\prime}-0^{\prime \prime}-44^{\prime}-6^{\prime \prime}$ & $T$ & $\# 6$ & 0.44 & 8 & $\# 7$ & 0.60 & $8 \frac{3}{4}$ & 1.25 \\
\hline
\end{tabular}

Circumferential Rebar

$$
\text { Al1 locations }
$$

Note that $A W$ rebar distribution in foundation slab is the same as in SY.

$T / B=$ Top and botton of foundation stab.

CC = Center-to-center distance between rebar at maximum radius indicated.

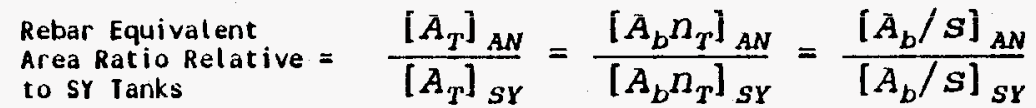

$A_{r}=A_{b} n_{1}$

$A_{1}=$ cross sectional area of reinforcing bar

$\mathrm{n}_{\mathrm{T}}=$ total number of reinforcing bar in a given plane

$=2 x R / s$ for meridional bars

$s$ = center-to-center (CC) spacing between reinforcing bars measured

along circumference at radius $R$

in $=$ number of planes containing reinforcing bars. 
Table 9. Deformed Reinforcing Bars.

(Nilson and Winter 1991)

ASTM A615, A616, A617, and A706

\begin{tabular}{|c|c|c|c|}
\hline \multirow{2}{*}{$\begin{array}{c}\text { Bar Size } \\
\text { Designation } \\
\text { No. }\end{array}$} & \multicolumn{2}{|c|}{ Nominal Dimensions } & \multirow[b]{2}{*}{$\begin{array}{l}\text { Weight } \\
(1 \mathrm{~b} / \mathrm{ft})\end{array}$} \\
\hline & $\begin{array}{c}d \\
\text { Diameter } \\
\text { (in.) }\end{array}$ & $\begin{array}{c}A_{b} \\
\text { Area } \\
\left(i n^{2}\right) \\
\end{array}$ & \\
\hline 3 & 0.375 & 0.11 & 0.376 \\
\hline 4 & 0.500 & 0.20 & 0.668 \\
\hline 5 & 0.625 & 0.31 & 1.043 \\
\hline 6 & 0.750 & 0.44 & 1.502 \\
\hline 7 & 0.875 & 0.66 & 2.044 \\
\hline 8 & 1.000 & 0.79 & 2.670 \\
\hline 9 & 1.128 & 1.00 & 3.400 \\
\hline 10 & 1.270 & 1.27 & 4.303 \\
\hline 11 & 1.410 & 1.56 & 5.313 \\
\hline 14 & 1.693 & 2.25 & 7.65 \\
\hline 18 & 2.257 & 4.00 & 13.60 \\
\hline
\end{tabular}

Grades $40,50,60$, and $70 \mathrm{kip} / \mathrm{in}^{2}$ 
Table 10. Minimum Strength, Ductility and Toughness Ratio of Steel Liners

(Primary and Secondary Tanks) vs. Temperature.

\begin{tabular}{|c|c|c|c|c|c|c|c|c|c|}
\hline \multirow{2}{*}{$\begin{array}{c}\text { Tenperature } \\
\left({ }^{\circ} \mathrm{F}\right)\end{array}$} & \multicolumn{3}{|c|}{ A516 Gr $65{ }^{1}$ (SY Tanks) } & \multicolumn{3}{|c|}{$\begin{array}{l}\text { A537 Class } 1^{1} \text { (aw an Tanks) } \\
\text { (2\%/2-in. thick plate and under) }\end{array}$} & \multicolumn{2}{|c|}{$\begin{array}{c}\text { Strength Ratio } \\
\text { A537/A516 }\end{array}$} & \multirow{2}{*}{$\begin{array}{c}\text { Toughness } \\
\text { Ratio } \\
\text { A537/A516 }\end{array}$} \\
\hline & (kip $\left.{ }^{s} y_{i n}^{2}\right)$ & (kip $\left.{ }^{\mathrm{s}} \mathrm{Hn}_{n}^{2}\right)$ & $\begin{array}{l}\text { IE } \\
(\%)\end{array}$ & (kip $\left.{ }^{s} y_{i n}^{2}\right)$ & (kip $\left.\mathrm{SH}^{2}\right)$ & $\underset{(\%)}{\text { TE }}$ & $s_{y}$ & $\mathbf{s}_{u}$ & \\
\hline-20 to 100 & 35 & \multirow[t]{8}{*}{65} & $23 / 19$ & 50 & \multirow[t]{2}{*}{70} & $22 / 18$ & 1.43 & \multirow[t]{2}{*}{1.08} & 1.14 \\
\hline 200 & 31.9 & & $19.5 / 16.1$ & 44.1 & & $18.6 / 15.2$ & 1.38 & & 1.12 \\
\hline 300 & 31 & & $17.8 / 14.7$ & 40.5 & \multirow[t]{6}{*}{68.6} & $17 / 13.9$ & 1.31 & \multirow[t]{6}{*}{1.06} & 1.08 \\
\hline 400 & 30 & & $16.8 / 13.9$ & 37.5 & & $16.1 / 13.2$ & 1.25 & & 1.06 \\
\hline 500 & 28.3 & & $16.3 / 13.5$ & 35.2 & & $15.6 / 12.8$ & 1.24 & & 1.05 \\
\hline 600 & 25.9 & & $18.7 / 15.5$ & 33.9 & & $17.9 / 14.7$ & 1.31 & & 1.07 \\
\hline 650 & 25.4 & & $21.2 / 17.5$ & 33.0 & & $20.3 / 16.6$ & 1.30 & & 1.06 \\
\hline 700 & 25.2 & & $23.9 / 19.8$ & 32.1 & & $22.9 / 18.7$ & 1.27 & & 1.06 \\
\hline
\end{tabular}

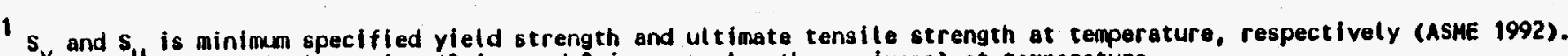
If is gifimum total elongation (2-in. and 8 -in. gage length specimens) at temperature. Temperature dependence of TE obtained from IE relation for A515 and A516, Grade 70 (HSHH) normalized to value at room temperature.

2 Toughness ratio between $A 537$ and $A 516$ is defined as $\left[U_{T}\right]_{A 537} /\left[U_{T}\right]_{A 516}$ where

$$
U_{T}=\frac{S_{y}+S_{u}}{2} T E
$$


WHC-SD-WM-SAR-064, Rev. 0

APPENDIX E

DYNAMIC LOAD FACTORS

$E-i$ 
WHC-SD-WM-SAR-064, Rev. 0

This page intentionally left blank. 
From: Component Stress Analysis

Phone: 6-1063 H5-56

CSA:CJM:ggb: $93 / 3$

Date: February 22, 1993

Subject: TANK 241-SY-101 PRESSURIZATION: EQUIVALENT PRESSURE FACTORS

To:
D. D. Stepnewski
H4-62

$\begin{array}{ll}\text { cc: G. M. Christensen } & H 4-21 \\ \text { G. L. Fox } & L 5-01 \\ \text { O. J. Green } & H 5-56 \\ \text { J. M. Grigsby } & H 4-62 \\ \text { J. D. Hopkins } & \text { R2-11 } \\ \text { G. D. Johnson } & \text { R2-78 }\end{array}$

L. J. Julyk

R. M. Marusich

J. B. Truitt

R. J. Van Vleet

CJM File/LB
H5-56

GI-67

H5-56

$\mathrm{H} 4-62$

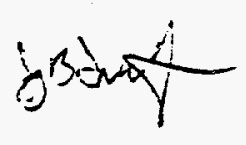

Reference: L. J. Julyk, et al., "Structural Integrity Evaluation of Double-Shell Waste Tank 241-SY-101 Under a Postulated Hydrogen Burn," WHC-SD-WM-TI-465, Rev. O, April 1991, Westinghouse Hanford Company, Richland, Washington.

The energy absorbed by the 241-SY-101 tank during a postulated dynamic hydrogen burn event can be related to a simpler static pressurization with well defined tank damage versus static pressure. This relation can be estimated by employing a dynamic amplification factor on the static pressure.

The mechanical work done by the gas in the primary liner on the tank system can be seen in Figures 1 and 2 as the areas under the respective volume change versus pressure plots. Figure 1 gives the results of an ABAQUS model of the 241-SY-101 tank without any side soil induced friction. While, Figure 2 gives results with a side soil friction coefficient of 0.57 .

The static analyses 1 ines of Figures 1 and 2 are seen to have similar characteristic shapes. The pressure at maximum slope change is $36 \mathrm{lbf} / \mathrm{in}^{2}$ in Figure 2 as compared to $22 \mathrm{lbf} / \mathrm{in}^{2}$ in Figure 1 . The large slope change and increase in nonlinearity coincides with the tank side wall lifting off the foundation pad (241-SY-101 has no reinforcement tieing the wal1 into the foundation) and the bottom of the tank deflecting to approximate a hemispherical shape. The addition of soil friction delays the side-wall liftoff until a higher pressure is obtained.

Figures 1 and 2 both show that postulated dome gas burn times of $1.0 \mathrm{sec}$ trace the respective static analysis case until the point of tank side-wall liftoff. In Figure 1 , the $0.01-\mathrm{sec}$ burn time is seen to peak at a pressure almost matching the constant volume burn pressure with very little volumetric expansion. The $0.01-\mathrm{sec}$ burn line can then be seen to follow an adiabatic expansion line and merges with the $1.0-\mathrm{sec}$ analysis case.

Slower burn times would have a characteristic shape between that of the $1.0-\mathrm{sec}$ burn case and the static analysis trend. The maximum volume change 
D. D. Stepnewski

Page 2

CSA:CJM: ggb: $93 / 3$

February 22, 1993

and the maximum mechanical work done on the tank system may be greater than shown in the plots and the summary table. The tank responded during the 1 -sec burn cases resulting in a maximum deflection in about 1.5 seconds. If the burn time was increased to tune with the tank response an increase in the maximum deflection (increased amplification) would be expected. Tuning with the structural response for a linear elastic system can be simply related to the normal mode shapes and frequencies of the liner system. The 241-5Y-101 tank and the resulting ABAQUS finite-element model is highly nonlinear and the equivalent linear mode shapes and frequencies shift with tank damage (concrete cracking). Tuning the pressure load to the $5 Y-101$ tank nonlinear response requires a parametric study tracking the shifting response time.

Tabie 1 give amplification factors derived from the existing ABAQUS analyses. These factors are conservative for application to dome burn times of 1 sec or less when employed with failure criteria curves of figure 3 developed for static pressurization with a side soil friction condition. The static pressure curves given in Figure 3 are based on the case with side soil friction because this results in larger strains in the dome. I would recommend using the amplification factors and curves with side-soil friction coefficient of 0.57 as being the most realistic.

Failure of the 241-SY-101 tank under a postulated hydrogen burn event is assumed to occur when the strain at local discontinuities in the primary steel liner exceed the ductility of the linear material, with appropriate reduction factors to account for multiaxial loading and weids. The resulting peak membrane principal strains at structural discontinuities in the dome are shown in Figure 3 as a function of static internal pressure. Effective ductility limits for the primary liner material (ASTM 516-Gr 65 ) are also shown for the base metal and welds. The strain limit for welds is conservatively taken as $1 / 2$ the corresponding 1 imit of the base metal. The maximum local strain location occurs at the intersection of the $4-$ in. penetration in the pump pit with the $3 / 3-t 0-1 / 2$ in. thickness transition in the primary liner dome region.

The procedure for obtaining the limiting constant volume burn pressure is given in Table 1. However, this procedure should be used with caution in extrapolation to other burn times and volumes outside of analysis data. 
WHC-SD-WM-SAR-064, Rev. 0

D. D. Stepnewski

Page 3

February 22, 1993

The Bureau of Mines test data implies the time for a real burn could be greater than $1 \mathrm{sec}$. While, LANL chemical kinematics calculations predict a burn time of around 0.6 second. A proposal is being prepared for an engineering effort to investigate burn time variability and resulting effect on 241-SY-101 tank response.

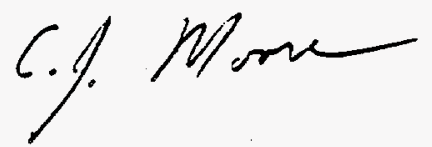

C. J. Moore, Principal Engineer

Component Stress Analysis

$g g b$

Attachments 
BTORAGE TANK 2\$1-8Y-201 YO BIDB WALC BRICTION ABAQDS DOYOE EIDROGEX, SITROCS I AIR BURX YODEI MOALIMEAR LARGE DERLECTION DYAAMIC ANAIYSIS VBRSUB YOALIMEAR IARGB DERTBCTION STAIIC ANALYSIS $(2 / 18 / 93$ cor 1$)$

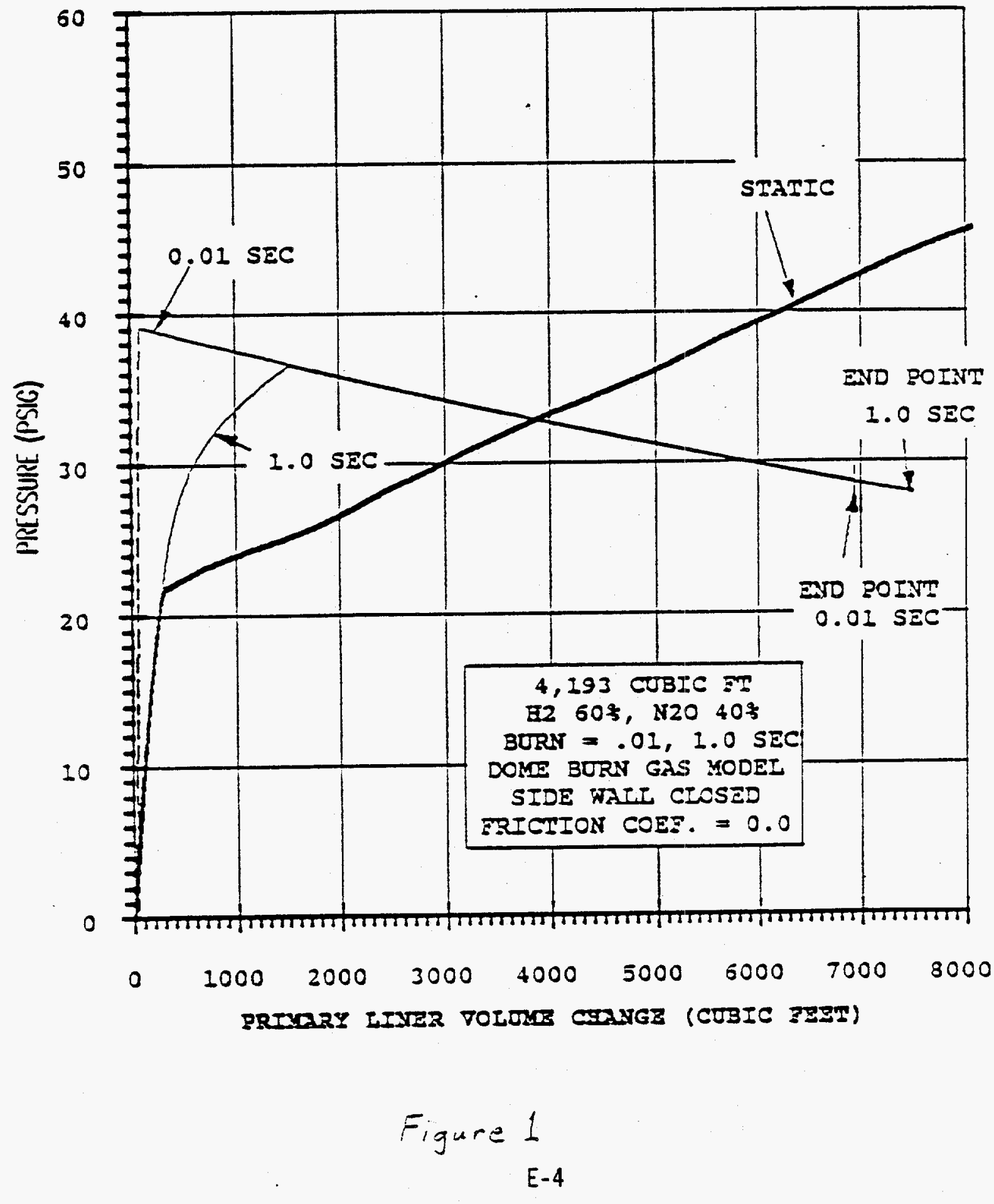


L2WFISPY.XLC

WHC-SD-WM-SAR-064, Rev. 0

STORAGB TANK 241-8T-101 TITH SIDE WALC FRICTIOX ABAQOS DOKC EYDROGEN, SIITROUS E AIR BURN YODEL HOALIAEAR LARGE DEFLECTION DYAAMITC ANRAYYSIS TERSTS MONLINEAR LARGE DEZLZCTION STATIC ANALYSIS

$(2 / 18 / 93$ Cor $)$

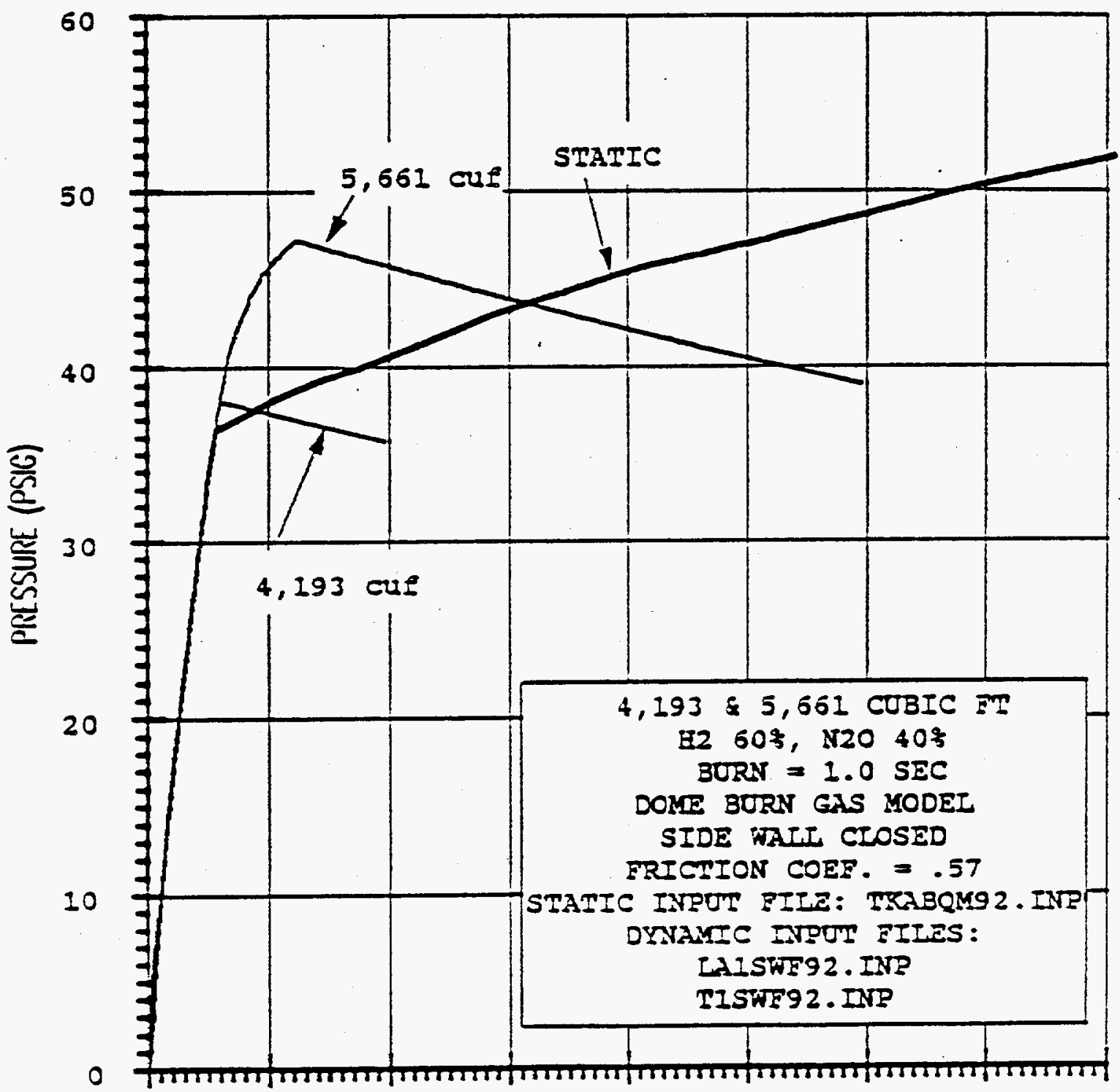

$\begin{array}{lllllllll}0 & 1000 & 2000 & 3000 & 4000 & 5000 & 6000 & 7000 & 3000\end{array}$ PRIMARY IISER TOLOAB CEANGE (CUBIC FEET)

Figure 2 
241-SY-101 Tank Dome Local Discontinuitles Peak Membrane Principal Strain v8. Statlc Pressure with Side-Soll Friction

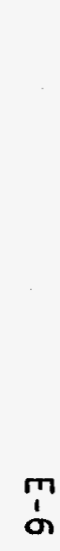

\section{Strain (\%)}

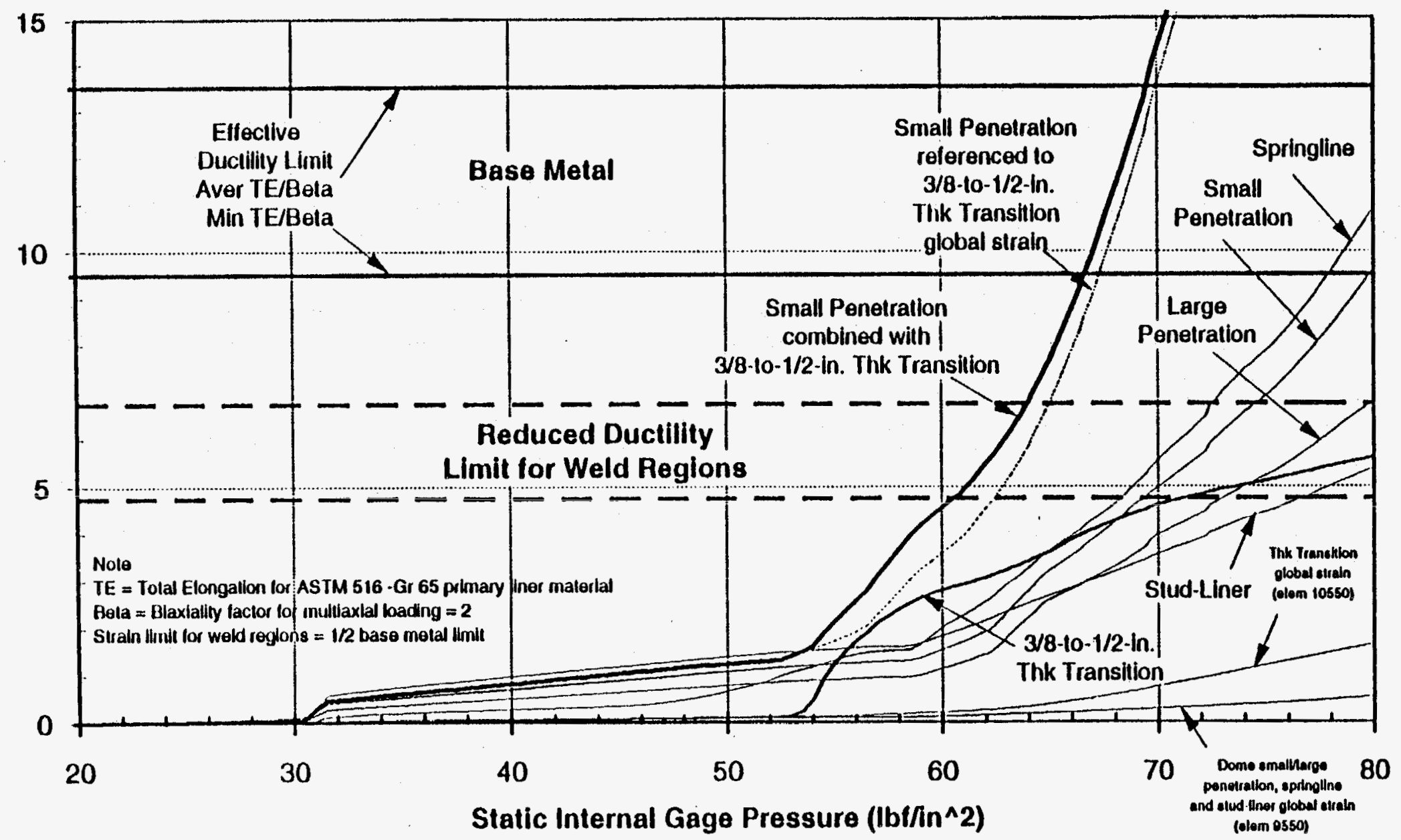

$$
\text { Figure } 3
$$


Table 1. 241-SY-101 TANK ABAqUS DYNAMIC ANALYSIS SUMMARY.

\begin{tabular}{|c|c|c|c|c|c|c|c|c|c|}
\hline \multirow[t]{2}{*}{$\begin{array}{l}\text { Burn rime } \\
\text { (sec) }\end{array}$} & \multirow{2}{*}{$\begin{array}{l}\text { Lateral } \\
\text { Soil Friction } \\
\text { Coefficient }\end{array}$} & \multirow{2}{*}{$\begin{array}{c}\mathrm{H}_{2}+\mathrm{H}_{2} \mathrm{O} \\
\mathrm{G}_{3} \mathrm{Vol}_{\mathrm{s}} \\
\left(\mathrm{ft}^{3} \text { a } 100 \text { of }\right) \\
\text { (see Note } 1)\end{array}$} & \multirow{2}{*}{$\begin{array}{l}\text { Dynamic Maximum } \\
\text { Pressure } \\
\text { (Ibf/in' (gauge)) }\end{array}$} & \multirow{2}{*}{$\begin{array}{l}\text { Adiabatic } \\
\text { Constant } \\
\text { Volune Burn } \\
\text { Pressure }\end{array}$} & \multirow{2}{*}{$\begin{array}{l}\text { Oynamic } \\
\text { Maximum a } \\
\text { Volyme } \\
\left(\mathrm{ft}^{3}\right)\end{array}$} & \multirow{2}{*}{$\begin{array}{c}\text { Maximum } \\
\text { Mechanical } \\
\text { Nork } \\
\text { (ft-lbf) }\end{array}$} & \multicolumn{3}{|c|}{$\begin{array}{l}\text { Factors } \\
\text { (see Note 2) }\end{array}$} \\
\hline & & & & & & & $a_{1}$ & $\alpha_{2}$ & $a$ \\
\hline 0.01 & 0.0 & 4,193 & 39.0 & -39 & 6,943 & $3.3 \times 10^{7}$ & 1.0 & 1.08 & 1.08 \\
\hline 1.0 & 0.0 & 4,193 & 36.1 & -39 & 7,492 & $3.37 \times 10^{7}$ & 1.08 & 1.22 & 1.13 \\
\hline 1.0 & 0.57 & 4,193 & 38.1 & -39 & 1,957 & $0.91 \times 10^{7}$ & 1.02 & 1.06 & 1.04 \\
\hline 1.0 & 0.57 & 5,661 & 47.2 & 50 & 5,950 & $3.49 \times 10^{7}$ & 1.06 & 1.03 & 0.97 \\
\hline
\end{tabular}

Note 1: Burp gas assumed $\mathrm{H}_{2}, 60$ percent and $\mathrm{N}_{2} \mathrm{O}, 40$ percent.

$9 \quad A$ burn of $4,193 \mathrm{ft}^{3}$ burp gas with air produces $1.978 \times 10^{8} \mathrm{cal}\left(6.106 \times 10^{8} \mathrm{ft}-1 \mathrm{bf}\right)$.

1 A burn of $5,661 \mathrm{ft}^{3}$ burp gas with air produces $2.671 \times 10^{8} \mathrm{cal}\left(8.245 \times 10^{8} \mathrm{ft}-1 \mathrm{bf}\right)$.

Note 2:

$\alpha_{1}\left(t_{\text {burn }}=\frac{P_{\text {constant volume burn }}^{\text {peak }}}{P_{\text {dynawic burn with volume change }}^{\text {peak }}}\right.$

$\alpha_{2}\left(t_{\text {burn }}\right)=\frac{P_{\text {static for faliure curve }}}{P_{\text {dynamic burs with vol ume change }}^{\text {peak }}}$

$\alpha \quad=\frac{\alpha_{2}}{\alpha_{1}}$

$\left(P_{\text {constanc volume burn }}^{\text {peik }}\right)_{\text {limit }}=\frac{1}{\alpha\left(t_{\text {burn }}\right)} P_{\text {static fallure curve }}^{\text {limit }}$ side soil friction $)$ 
WHC-SD-WM-SAR-064, Rev. 0

This page intentionally left blank. 
WHC-SD-WM-SAR-064, Rev. 0

\section{APPENDIX $F$}

RADIOLOGICAL DOSE CALCULATIONS

$F-i$ 
WHC-SD-WM-SAR-064, Rev. 0

This page intentionally left blank. 


\title{
RADIOLOGICAL DOSE CALCULATIONS FOR TWO POSTULATED HYDROGEN BURN CASES IN TANK 104-AN
}

\author{
D.A. Himes \\ $5 / 9 / 94$
}

Radiological dose consequences are required for two specified releases due to postulated hydrogen burns in Tank 104-AN [1]. These doses are to be combined with doses due to a previously analyzed release from a tank ventilation system [2]. The exhaust system releases are based on window $C$ crust samples from Tank 101-SY.

\section{Source Term:}

Two releases of crust material due to the postulated hydrogen burns were specified [1]. The two cases were designated as Best Estimate and Conservative Bounding, and are shown in Table 1.

Table 1: Specified releases of crust material due to postulated hydrogen burns in Tank 104-AN

\begin{tabular}{lll} 
& \multicolumn{2}{c}{ Release (Ci) } \\
\cline { 2 - 3 } Isotope & $\begin{array}{c}\text { Best } \\
\text { Estimate }\end{array}$ & $\begin{array}{c}\text { Conservative } \\
\text { Bounding }\end{array}$ \\
\hline Sr-90 & $7.5 \mathrm{E}-3$ & $2.5 \mathrm{E}-2$ \\
Tc-99 & $1.6 \mathrm{E}-3$ & $4.8 \mathrm{E}-2$ \\
$\mathrm{I}-129$ & $6.5 \mathrm{E}-5$ & $2.2 \mathrm{E}-4$ \\
$\mathrm{Cs}-137$ & $3.7 \mathrm{E}-1$ & $6.8 \mathrm{E}+0$ \\
Np-237 & $1.2 \mathrm{E}-4$ & $3.6 \mathrm{E}-4$ \\
$\mathrm{Pu}-239$ & $1.7 \mathrm{E}-5$ & $5.6 \mathrm{E}-5$ \\
$\mathrm{Am}-241$ & $2.5 \mathrm{E}-4$ & $8.4 \mathrm{E}-4$
\end{tabular}

The isotopic mix of the material in the exhaust system is assumed to be the same as that for the crust sample material from 101-SY. The release developed previously [2] corresponds to $360 \mathrm{~g}$ of crust material containing the isotopic mix shown in Table 2 . 
WHC-SD-WM-SAR-064, Rev. 0

Table 2: Isotopic releases from the primary

exhaust system inventory only

Isotope Release (Ci)

\begin{tabular}{ll}
\hline Sr 90 & $1.2 \mathrm{E}-2$ \\
Tc 99 & $1.3 \mathrm{E}-4$ \\
$\mathrm{I} 129$ & $1.0 \mathrm{E}-4$ \\
Cs 137 & $1.5 \mathrm{E}-1$ \\
Np 237 & $1.8 \mathrm{E}-4$ \\
Pu 239 & $6.1 \mathrm{E}-6$ \\
Am 241 & $5.8 \mathrm{E}-5$
\end{tabular}

It is conservatively assumed that the releases are entirely in the form of respirable $(<10 \mu \mathrm{m})$ particles. Worst-case solubilities are assumed.

\section{Receptor Descriptions:}

Onsite:

Normally the receptor at a distance of $100 \mathrm{~m}$ in the worst direction [3]. Doses calculated for this receptor include inhalation and submersion. The release in this case is assumed to take place in a short time so no credit was taken for evacuation.

Site Boundary:

Receptor at the site boundary in the worst direction. This receptor is assumed to stay at this location for the duration of the accident. Doses calculated include inhalation and submersion. In sectors where the site is bounded by the Columbia River, this receptor is assumed to be located on the near bank of the river.

Agricultural Area:

Residence of the ingestion pathway receptor (IPR). This receptor is assumed to grow his own food, including a variety of crops, meat and dairy products and to continue to do so at this location for 50 years following the accident. No credit is taken for uncontaminated foodstuffs brought in from outside the area. Note that IPR ingestion doses are reported only as a measure of economic damage since, in the case of an accident, any contaminated land or products would not be used. Ingestion and ground shine would not, therefore, be actual exposure pathways. The release is assumed to occur just prior to the autumn harvest in order to maximize consequences with regard to the time of the accident. In sectors where the site is bounded by the Columbia River, this receptor is assumed to be located on the far bank of the river. 
WHC-SD-WM-SAR-064, Rev. 0

Transport Assumptions:

Acute 99.5 percentile ground level release dispersion factors $(X / Q)$ were generated using the GXQ code [4] for each of the 16 sectors at a distance of $100 \mathrm{~m}$ and at the site boundary. 95 percentile dispersion factors were al so generated over all 16 sectors. These results are summarized in Tables 3 and 4 below. The asterisks in the tables identify the worst case locations. For this release location the agricultural location corresponding to the maximum ingestion pathway receptor (IPR) is on the east bank of the river.

Table 4: Acute 99.5 percentile $X / Q$ values at $100 \mathrm{~m}$ onsite locations for ground level releases in the 200 Areas

\begin{tabular}{ll} 
Sector & $x / Q\left(\mathrm{~s} / \mathrm{m}^{3}\right)$ \\
\hline S & $1.56 \mathrm{E}-2$ \\
SSW & $1.13 \mathrm{E}-2$ \\
SW & $1.21 \mathrm{E}-2$ \\
WSW & $1.22 \mathrm{E}-2$ \\
W & $2.80 \mathrm{E}-2$ \\
WNW & $1.60 \mathrm{E}-2$ \\
NW & $2.89 \mathrm{E}-2$ \\
NNW & $2.90 \mathrm{E}-2$ \\
N & $3.12 \mathrm{E}-2$ \\
NNE & $1.54 \mathrm{E}-2$ \\
NE & $1.57 \mathrm{E}-2$ \\
ENE & $2.52 \mathrm{E}-2$ \\
E & $3.41 \mathrm{E}-2$ \\
ESE & $3.25 \mathrm{E}-2$ \\
SE & $3.07 \mathrm{E}-2$ \\
SSE & $1.58 \mathrm{E}-2$ \\
A11 (95\%) & $3.44 \mathrm{E}-2 *$
\end{tabular}


WHC-SD-WM-SAR-064, Rev. 0

Table 5: Acute 99.5 percentile $X / Q$ values at offsite locations for ground level releases in the AN Tank Farm

\begin{tabular}{lll} 
Sector & Dist. $(\mathrm{km})$ & $\times / Q\left(\mathrm{~s} / \mathrm{m}^{3}\right)$ \\
\hline S & 21.1 & $4.34 \mathrm{E}-6$ \\
SSW & 18.3 & $3.31 \mathrm{E}-6$ \\
SW & 18.3 & $4.23 \mathrm{E}-6$ \\
WSW & 22.4 & $3.30 \mathrm{E}-6$ \\
W & 22.2 & $7.91 \mathrm{E}-6$ \\
WNW & 22.6 & $4.33 \mathrm{E}-6$ \\
NW & 22.2 & $8.21 \mathrm{E}-6$ \\
NNW & 22.2 & $8.24 \mathrm{E}-6$ \\
N & 25.3 & $7.52 \mathrm{E}-6$ \\
NNE & 24.4 & $3.42 \mathrm{E}-6$ \\
NE & 19.1 & $5.03 \mathrm{E}-6$ \\
ENE & 15.9 & $1.08 \mathrm{E}-5$ \\
E & 15.9 & $1.45 \mathrm{E}-5$ \\
ESE & 20.0 & $1.04 \mathrm{E}-5$ \\
SE & 24.4 & $7.74 \mathrm{E}-6$ \\
SSE & 21.1 & $4.47 \mathrm{E}-6$ \\
A11. (95\%) & & $9.87 \mathrm{E}-6$
\end{tabular}

Code Documentation:

GXQ version $3.1(6 / 8 / 93)$ [4]

Joint Frequency Data: 200 Area, $10 \mathrm{~m}$, Pasquill A-G (1983-1991 Average)

GXQ input/output files are attached for reference.

GENI I version $1.485(12 / 3 / 90)$ [5]

GENI I Default Parameter Values $(3 / 28 / 90)$

Radionuclide Library - Times $<100$ years $(7 / 23 / 93)$

External Dose Factor Library (5/8/90)

Worst-Case Solubilities, Yearly Dose Increments (7/23/93)

Metabolic Parameters $(8 / 12 / 88)$

PNL Food Transfer Factor Library (7/19/93)

Typical GENII input files are attached for reference.

\section{Results:}

The resulting 50 year committed doses to the three receptor types are shown in Tables 6 and 7 for the two releases from the tank only. The doses due to the assumed release from the primary tank exhaust system are shown in Table 8. 
Finally, the doses for the combined tank + exhaust system releases are shown in Tables 9 and 10. Submersion doses were calculated using a semi-infinite cloud model. Note that the site boundary receptor and ingestion pathway receptor (IPR) are at the same location for these releases. Bone $S$ dose refers to bone surface dose.

Table 6: Resulting doses for Best Estimate release from tank only

\begin{tabular}{|c|c|c|c|}
\hline Receptor & Dose Type & EDE & $\begin{array}{l}\text { (rem) } \\
\text { Limiting Organ }\end{array}$ \\
\hline $\begin{array}{l}\text { Onsite } \\
(100 \mathrm{~m})\end{array}$ & $\begin{array}{l}\text { Inhalation } \\
\text { Submersion } \\
\text { Total }\end{array}$ & $\begin{array}{l}2.4 E+0 \\
1.5 E-3 \\
2.4 E+0\end{array}$ & $\begin{array}{l}4.5 \mathrm{E}+1 \text { (Bone S) } \\
\frac{1.5 \mathrm{E}-3}{4.5 \mathrm{E}+1} \text { (Bone S) }\end{array}$ \\
\hline $\begin{array}{c}\text { Site Boundary } \\
(14.5 \mathrm{~km} \mathrm{E})\end{array}$ & $\begin{array}{l}\text { Inhalation } \\
\text { Submersion } \\
\text { Total }\end{array}$ & $\begin{array}{l}9.9 E-4 \\
6.2 E-7 \\
9.9 E-4\end{array}$ & $\begin{array}{l}1.9 \mathrm{E}-2 \text { (Bone } S \text { ) } \\
\frac{6.2 \mathrm{E}-7}{1.9 \mathrm{E}-3} \text { (Bone } S \text { ) }\end{array}$ \\
\hline $\begin{array}{c}\text { IPR } \\
(14.5 \mathrm{~km} \mathrm{E})\end{array}$ & $\begin{array}{l}\text { Inhalation } \\
\text { Submersion } \\
\text { Ingestion } \\
\text { Ground Shine } \\
\text { Total }\end{array}$ & $\begin{array}{l}9.9 E-4 \\
6.2 E-7 \\
3.3 E-2 \\
1.1 E-3 \\
3.5 E-2\end{array}$ & $\begin{array}{l}1.9 \mathrm{E}-3 \text { (Bone } S \text { ) } \\
6.2 \mathrm{E}-7 \\
5.1 \mathrm{E}-2 \text { (Bone } S \text { ) } \\
\frac{1.1 \mathrm{E}-3}{5.4 \mathrm{E}-2} \text { (Bone } S \text { ) }\end{array}$ \\
\hline
\end{tabular}

Table 7: Resulting doses for Bounding release from tank only

\begin{tabular}{|c|c|c|c|}
\hline Receptor & Dose Type & EDE & $\begin{array}{l}\text { (rem) } \\
\text { Limiting Organ }\end{array}$ \\
\hline $\begin{array}{l}\text { Onsite } \\
(100 \mathrm{~m})\end{array}$ & $\begin{array}{l}\text { Inhalation } \\
\text { Submersion } \\
\text { Total }\end{array}$ & $\begin{array}{l}9.5 E+0 \\
2.7 E-2 \\
9.5 E+0\end{array}$ & $\begin{array}{l}1.4 \mathrm{E}+2 \text { (Bone } S) \\
\left.\frac{2.7 \mathrm{E}-2}{1.4 \mathrm{E}+2} \text { (Bone } \mathrm{S}\right)\end{array}$ \\
\hline $\begin{array}{c}\text { Site Boundary } \\
(14.5 \mathrm{~km} \mathrm{E})\end{array}$ & $\begin{array}{l}\text { Inhalation } \\
\text { Submersion } \\
\text { Total }\end{array}$ & $\begin{array}{l}4.0 E-3 \\
1.1 E-5 \\
4.0 E-3\end{array}$ & $\begin{array}{l}6.0 \mathrm{E}-2 \text { (Bone } S \text { ) } \\
\frac{1.1 \mathrm{E}-5}{6.0 \mathrm{E}-2} \text { (Bone } S \text { ) }\end{array}$ \\
\hline $\begin{array}{c}\text { IPR } \\
(14.5 \mathrm{~km} \mathrm{E})\end{array}$ & $\begin{array}{l}\text { Inhalation } \\
\text { Submersion } \\
\text { Ingestion } \\
\text { Ground Shine } \\
\text { Total }\end{array}$ & $\begin{array}{l}4.0 E-3 \\
1.1 E-5 \\
5.7 E-1 \\
2.0 E-2 \\
5.9 E-1\end{array}$ & $\begin{array}{l}6.0 \mathrm{E}-2 \text { (Bone } S \text { ) } \\
1.1 \mathrm{E}-5 \\
6.6 \mathrm{E}-1 \text { (Bone } S \text { ) } \\
\frac{2.0 \mathrm{E}-2}{7.4 \mathrm{E}-1} \text { (Bone } S \text { ) }\end{array}$ \\
\hline
\end{tabular}


WHC-SD-WM-SAR-064, Rev. 0

Table 8: Resulting doses for release from tank exhaust system

\begin{tabular}{|c|c|c|c|}
\hline Receptor & Dose Type & EDE & $\begin{array}{l}\text { (rem) } \\
\text { Limiting Organ }\end{array}$ \\
\hline $\begin{array}{l}\text { Onsite } \\
(100 \mathrm{~m})\end{array}$ & $\begin{array}{l}\text { Inhalation } \\
\text { Submersion } \\
\text { Total }\end{array}$ & $\begin{array}{l}1.7 \mathrm{E}+0 \\
5.8 \mathrm{E}-4 \\
1.7 \mathrm{E}+0\end{array}$ & $\begin{array}{l}3.5 \mathrm{E}+1 \text { (Bone } S \text { ) } \\
\frac{5.8 \mathrm{E}-4}{3.5 \mathrm{E}+1} \text { (Bone } S \text { ) }\end{array}$ \\
\hline $\begin{array}{l}\text { Site Boundary } \\
(14.5 \mathrm{~km} \mathrm{E})\end{array}$ & $\begin{array}{l}\text { Inhalation } \\
\text { Submersion } \\
\text { Total }\end{array}$ & $\begin{array}{l}7.2 E-4 \\
2.5 E-7 \\
7.2 E-4\end{array}$ & $\begin{array}{l}\frac{1.5 E-2}{2.5 E-7} \text { (Bone } S \text { ) } \\
\left.\frac{1.5 E-2}{1.50 n e} S\right)\end{array}$ \\
\hline $\begin{array}{c}\text { IPR } \\
(14.5 \mathrm{~km} \mathrm{E})\end{array}$ & $\begin{array}{l}\text { Inhalation } \\
\text { Submersion } \\
\text { Ingestion } \\
\text { Ground Shine } \\
\text { Total }\end{array}$ & $\begin{array}{l}7.2 \mathrm{E}-4 \\
2.5 \mathrm{E}-7 \\
1.5 \mathrm{E}-2 \\
4.4 \mathrm{E}-4 \\
1.6 \mathrm{E}-2\end{array}$ & $\begin{array}{l}1.5 \mathrm{E}-2 \text { (Bone } S \text { ) } \\
2.5 \mathrm{E}-7 \\
4.2 \mathrm{E}-2 \text { (Bone } S \text { ) } \\
\frac{4.4 \mathrm{E}-4}{5.7 \mathrm{E}-2} \text { (Bone S) }\end{array}$ \\
\hline
\end{tabular}

Table 9: Combined doses for Best Estimate release from tank + exhaust system

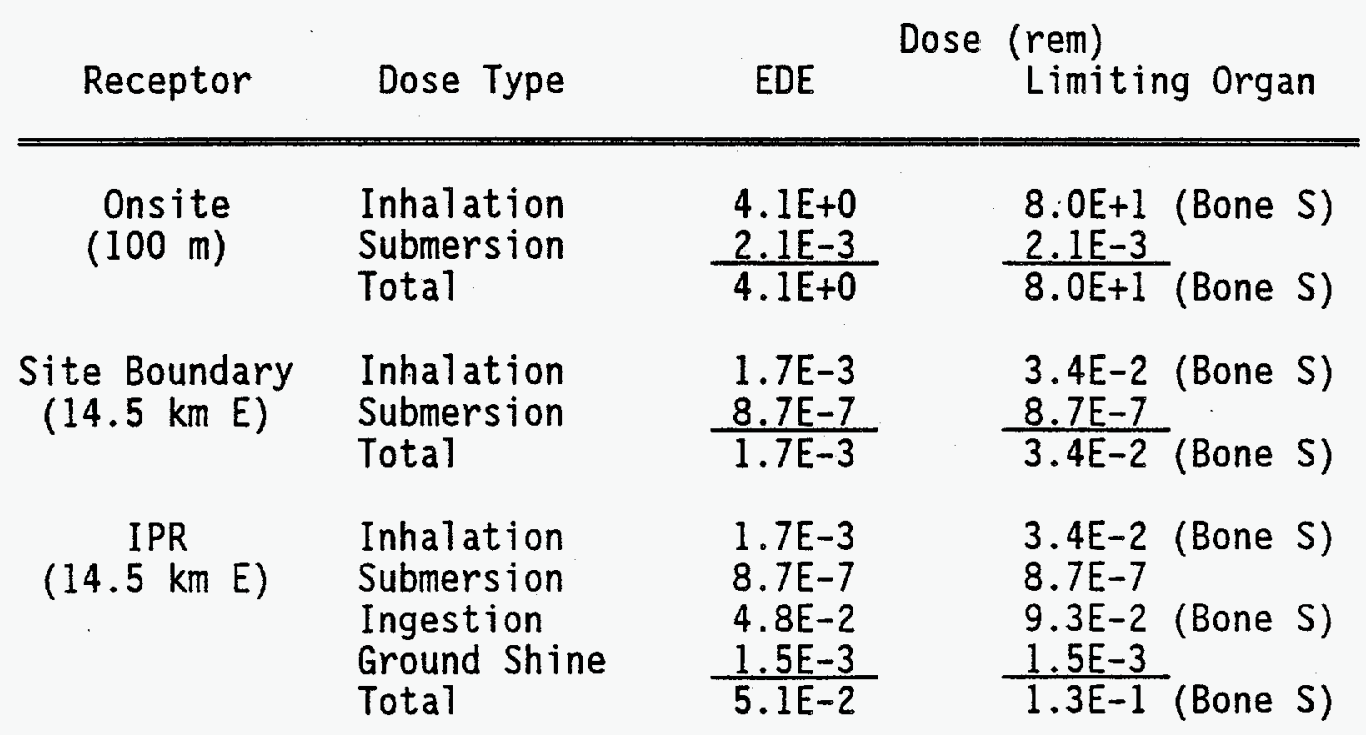


WHC-SD-WM-SAR-064, Rev. 0

Table 10: Combined doses for Bounding release

from tank + exhaust system

\begin{tabular}{|c|c|c|c|}
\hline Receptor & Dose Type & EDE & $\begin{array}{l}\text { (rem) } \\
\text { Limiting Organ }\end{array}$ \\
\hline $\begin{array}{l}\text { Onsite } \\
(100 \mathrm{~m})\end{array}$ & $\begin{array}{l}\text { Inhalation } \\
\text { Submersion } \\
\text { Total }\end{array}$ & $\begin{array}{l}1.1 \mathrm{E}+1 \\
2.8 \mathrm{E}-2 \\
1.1 \mathrm{E}+1\end{array}$ & $\begin{array}{l}1.8 \mathrm{E}+2 \text { (Bone } S \text { ) } \\
\frac{2.8 \mathrm{E}-2}{1.8 \mathrm{E}+2} \text { (Bone } \mathrm{S} \text { ) }\end{array}$ \\
\hline $\begin{array}{l}\text { Site Boundary } \\
(14.5 \mathrm{~km} \mathrm{E})\end{array}$ & $\begin{array}{l}\text { Inhalation } \\
\text { Submersion } \\
\text { Total }\end{array}$ & $\begin{array}{l}4.7 E-3 \\
1.1 E-5 \\
4.7 E-3\end{array}$ & $\begin{array}{l}7.5 E-2 \text { (Bone S) } \\
\frac{1.1 E-5}{7.5 E-2} \text { (Bone S) }\end{array}$ \\
\hline $\begin{array}{c}\text { IPR } \\
(14.5 \mathrm{~km} \mathrm{E})\end{array}$ & $\begin{array}{l}\text { Inhalation } \\
\text { Submersion } \\
\text { Ingestion } \\
\text { Ground Shine } \\
\text { Total }\end{array}$ & $\begin{array}{l}4.7 E-3 \\
1.1 \mathrm{E}-5 \\
5.9 \mathrm{E}-1 \\
2.0 \mathrm{E}-2 \\
6.2 \mathrm{E}-1\end{array}$ & $\begin{array}{l}7.5 \mathrm{E}-2 \text { (Bone } S \text { ) } \\
1.1 \mathrm{E}-5 \text { (Bone } S \text { ) } \\
7.0 \mathrm{E}-1 \text { (B) } \\
\frac{2.0 \mathrm{E}-2}{8.0 \mathrm{E}-1 \text { (Bone } S}\end{array}$ \\
\hline
\end{tabular}

\section{References:}

1. Memo, D.D. Stepnewski to D.A Himes, "Radiological Dose Calculations for Tank Postulated Hydrogen Burn Cases - Crust Composite Source Term Revised Apri1 20, 1994," 29140-DDS-94004, Apri1 20, 1994.

2. Memo, D.A. Himes to D.D. Stepnewski, "Radiological Dose Analysis of Two Hydrogen Burns in Tank 101-SY and a Sample Spi11 Based on Window C Samples, " 29250-DAH-92015, August 7, 1992.

3. Nonreactor Facility Safety Analys is Manual, Westinghouse Hanford Co., WHC-CM-4-46, September, 1988.

4. B.E. Hey, GXO Program Users' Guide, WHC-SD-GN-SWD-30002, EDT 141669, June $8,1993$.

5. B.A. Napier, et al., GENII - The Hanford Environmental Radiation Dosimetry Software System, PNL-6484, Dec. 1988. 
GXQ Input/Output File

\subsection{Percentile Individual Sector - Onsite and Offsite}

\section{GXQ Version 3.1 B June 8, 1993}

General Purpose Atmospheric Dispersion Code Produced by Radiological \& Toxicological Analysis Westinghouse Hanford Company

Users Guide documented in WHC-SD-GN-SWD-3002 Rev. 0. Validation documented in WHC-SD-GN-SWD-3003 Rev. 0.

Code Custodian is Brit E. Hey, WHC, ext. 6-2921.

Run Date $=4 / 8 / 1994$

Run Time $=9: 5337.97$

\section{INPUT ECHO:}

Sector X/Qs for Tank 104-AN Hydrogen Burn C GXQ Ver. 3.1 Input File

c mode 1

C

c MODE CHOICE:

$C$ mode $=1$ then $X / Q$ based on Hanford site specific meteorology

$c$ mode $=2$ then $X / Q$ based on atmospheric stability class and wind speed

$c$ mode $=3$ then $X / Q$ p Tot file is created

$\mathrm{c}$

c LOGICAL CHOICES:

c ifox inorm icdf ichk isite ipop icon

$T \quad F \quad F \quad F \quad F \quad F \quad F$

$c$ ifox $=t$ then joint frequency used to compute frequency to exceed $X / Q$

$c=f$ then joint frequency used to compute annual average $X / Q$

$c$ inorm $=t$ then joint frequency data is normalized (as in GENII)

$c=f$ then joint frequency data is un-normalized

$c$ icdf $=t$ then cumulative distribution file created (CDF.OUT)

$c=f$ then no cumulative distribution file created

c ichk $=t$ then $X / Q$ parameter print option turned on

$c=f$ then no parameter print

$c$ isite $=t$ then $X / Q$ based on joint frequency data for all 16 sectors

$c=f$ then $X / Q$ based on joint frequency data of individual sectors

$c$ ipop $=t$ then $X / Q$ is population weighted

$c=f$ then no population weighting

$c$ icon $=t$ then $X / Q$ is air concentration

$c=f$ then $X / Q$ is integrated exposure

C

C MODEL CHOICES:

c idep iwake ipm irise igrav iwash iflow iwind 


\section{$\begin{array}{llllllll}0 & 0 & 0 & 0 & 0 & 0 & 0 & 0\end{array}$}

$c$ idep $=1$ then plume depletion model turned on (Chamberlain model)

c iwake $=1$ then NRC RG 1.145 building wake model turned on

c $\quad=2$ then MACCS virtual distance building wake model turned on

c $\mathrm{ipm}=1$ then NRC RG 1.145 plume meander model turned on

c $\quad=2$ then 5th Power Law plume meander model turned on

C

c irise $=1$ then momentum/buoyancy plume rise model turned on, buoyancy

c rise based on sensible heat emission

c $\quad=2$ then momentum/buoyancy plume rise model turned on, buoyancy

c rise based on initial plume density

c igrav = 1 then gravitational settling model turned on

c $i$ wash $=1$ then stack downwash model turned on

c iflow $=1$ then sigmas adjusted for volume flow rate

c iwind $=1$ then wind speed corrected for plume height

c $=0$ to turn any of the above models off

c

c PARAMETER INPUT:

c height

c (m)

(m) (m)

wind

speed mixing

height height

$0.00000 E+00$

1. $00000 E+01$

(m)

$1.00000 E+03$

frequency

to scaling

exceed

factor

$c$

c

building

width

(m)

$7.90000 \mathrm{E}+00$

building

height

(m)

3. $00000 E+00$

release

duration

(hr)

(\%)

(?)

5.00000E-01

1.00000E+00

C

c

C

initial

initial

plume

density

plume

1.00000E+00

deposition

velocity

$(\mathrm{m} / \mathrm{s})$

1. $00000 \mathrm{E}-03$

gravitational

settling

velocity

$(\mathrm{m} / \mathrm{s})$

1. $00000 \mathrm{E}-03$

c $(\mathrm{g} / \mathrm{cc})$

flow

rate

1.22000E-03

(m3/s)

sensible

heat

stack

diameter

$7.07000 \mathrm{E}+00$

(m)

3. $00000 \mathrm{E}+00$

emission

rate

(cal/s)

4.18000E+05

\section{C}

c RECEPTOR DEPENDENT DATA

c FOR MODE make

c 1 (site specific)

c 2 (by class \& wind speed)

c 3 (create plot file)

RECEPTOR DEPENDENT DATA

sector distance $z$-height

class windspeed distance offset $z$-height

C

C RECEPTOR PARAMETER DESCRIPTION:

c sector $=0,1,2 \ldots(\mathrm{a} 11, \mathrm{~S}$, SSW, etc.)

c distance $=$ meters

C class $=1,2,3,4,5,6,7$ (P-G stability class $A, B, C, D, E, F, G)$

$\mathrm{c}$ windspeed $=\mathrm{m} / \mathrm{s}$

$c$ offset $=$ meters offset from plume centerline

$c$ $x \max =$ maximum distance to plot or calculate to $(\mathrm{m})$

$c$ imax $=$ distance intervals

c $y \max =$ maximum offset to plot $(\mathrm{m})$ 
c jmax $=$ offset intervals

c $x q m i n=$ minimum scaled $X / Q$ to calculate

$c$ power $=$ exponent in power function step size

MODE:

Site specific $X / Q$ calculated

LOGICAL CHOICES:

Joint frequency used to calculate $X / Q$ based on

frequency of exceedance.

No normalization of joint frequency.

$X / Q$ calculated for single sector.

Output is atmospheric dispersion coefficient.

MODELS SELECTED:

WARNING/ERROR MESSAGES:

WARNING \#3 - Scaled X/Q units (shown as $\mathrm{s} / \mathrm{m} 3$ or $1 / \mathrm{m} 3$ below) do not reflect the user specified scaling factor.

JOINT FREQUENCY DATA:

200 AREA (HMS) - $10 \mathrm{M}$ - Pasquill A - G (1983 - 1991 Average)

Created $8 / 26 / 92 \mathrm{KR}$

Sector X/Qs for Tank 104-AN Hydrogen Burn

\begin{tabular}{|c|c|c|c|c|c|c|c|c|}
\hline CTOR & $\begin{array}{l}\text { DISTANCE } \\
(\mathrm{m})\end{array}$ & $\begin{array}{c}\text { RECEPT } \\
\text { HEIGHT } \\
(\mathrm{m})\end{array}$ & $\begin{array}{c}\text { SECT. } \\
\text { FREQ. } \\
(\%)\end{array}$ & POPULATION & $\begin{array}{c}\text { TOTAL. } \\
\text { POPULATION } \\
\text { SCALED } \\
X / Q \\
(\mathrm{~s} / \mathrm{m} 3)\end{array}$ & $\begin{array}{l}\text { AVERAGE } \\
\text { INDIVIDUAL } \\
\text { SCALED } \\
X / Q \\
(\mathrm{~s} / \mathrm{m} 3)\end{array}$ & $\begin{array}{l}\text { ATM. } \\
\text { STAB. } \\
\text { CLASS }\end{array}$ & $\begin{array}{l}\text { WIND } \\
\text { SPEED } \\
(\mathrm{m} / \mathrm{s})\end{array}$ \\
\hline $\begin{array}{l}\text { W } \\
\text { WNW } \\
\text { NW } \\
\text { NNW } \\
N \\
\text { NNE } \\
\text { NE } \\
\text { ENE } \\
\text { E } \\
\text { ESE } \\
\text { SE } \\
\text { SSE }\end{array}$ & $\begin{array}{l}100 \\
100 \\
100 \\
100 \\
100 \\
100 \\
100 \\
100 \\
100 \\
100 \\
100 \\
100 \\
100 \\
100 \\
100 \\
100 \\
21100\end{array}$ & $\begin{array}{l}0 \\
0 \\
0 \\
0 \\
0 \\
0 \\
0 \\
0 \\
0 \\
0 \\
0 \\
0 \\
0 \\
0 \\
0\end{array}$ & $\begin{array}{r}6.30 \\
4.53 \\
2.93 \\
2.72 \\
4.80 \\
3.98 \\
4.72 \\
4.58 \\
4.36 \\
2.49 \\
3.90 \\
6.17 \\
14.05 \\
18.80 \\
10.83 \\
4.78 \\
6.30\end{array}$ & 1 & $\begin{array}{l}2.52 \mathrm{E}- \\
3.41 \mathrm{E}- \\
3.25 \mathrm{E}- \\
3.07 \mathrm{E}- \\
1.58 \mathrm{E}- \\
4.34 \mathrm{E}-\end{array}$ & $\begin{array}{l}1.56 \mathrm{E}-02 \\
1.13 \mathrm{E}-02 \\
1.21 \mathrm{E}-02 \\
1.22 \mathrm{E}-02 \\
2.80 \mathrm{E}-02 \\
1.60 \mathrm{E}-02 \\
2.89 \mathrm{E}-02 \\
2.90 \mathrm{E}-02 \\
3.12 \mathrm{E}-02 \\
1.54 \mathrm{E}-02 \\
1.57 \mathrm{E}-02 \\
2.52 \mathrm{E}-02 \\
3.41 \mathrm{E}-02 \\
3.25 \mathrm{E}-02 \\
3.07 \mathrm{E}-02 \\
1.58 \mathrm{E}-02 \\
4.34 \mathrm{E}-06\end{array}$ & $\begin{array}{l}E \\
F \\
F \\
F \\
G \\
G \\
G \\
G \\
G \\
E \\
E \\
G \\
F \\
F \\
G \\
G \\
E\end{array}$ & $\begin{array}{r}2.6 \\
2.6 \\
2.6 \\
.8 \\
.8 \\
2.8 \\
.8 \\
2.6 \\
4.7\end{array}$ \\
\hline
\end{tabular}


WHC-SD-WM-SAR-064, Rev. 0

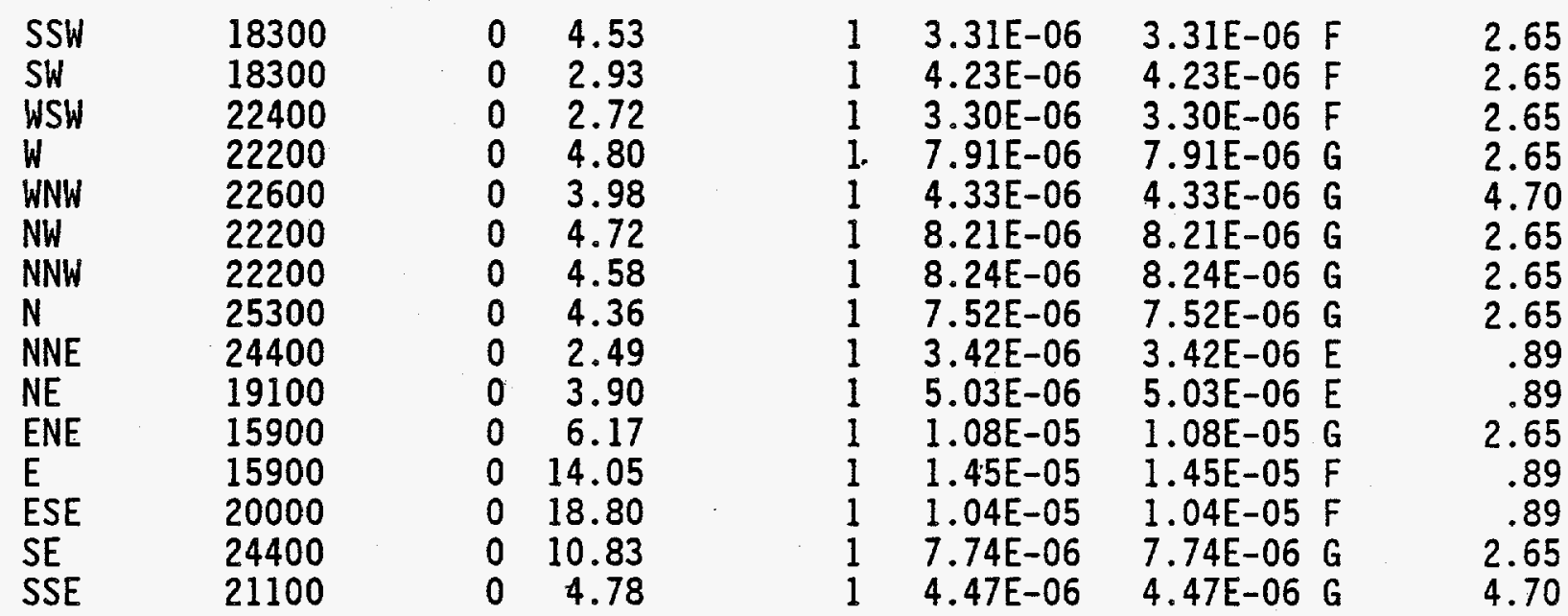


GXQ Input/Output File

95 Percentile All Sectors - Onsite

\section{GXQ Version 3.1 B June 8,1993}

General Purpose Atmospheric Dispersion Code

Produced by Radiological \& Toxicological Analysis

Westinghouse Hanford Company

Users Guide documented in WHC-SD-GN-SWD-3002 Rev. 0.

Validation documented in WHC-SD-GN-SWD-3003 Rev. 0.

Code Custodian is Brit E. Hey, WHC, ext. 6-2921.

Run Date $=3 / 31 / 1994$

Run Time $=14: 52 \quad 1.32$

INPUT ECHO:

Overall Site $X / Q$ s for Tank 104-AN Hydrogen Burn

c GXQ Ver. 3.1 Input File

C mode

1

C

c MODE CHOICE:

$C$ mode $=1$ then $X / Q$ based on Hanford site specific meteorology

$c$ mode $=2$ then $X / Q$ based on atmospheric stability class and wind speed

$c$ mode $=3$ then $X / Q$ plot file is created

c

c LOGICAL CHOICES:

c ifox inorm icdf ichk isite ipop icon

$c$ ifox $=t$ then joint frequency used to compute frequency to exceed $X / Q$

$c=f$ then joint frequency used to compute annual average $X / Q$

$c$ inorm $=t$ then joint frequency data is normalized (as in GENII)

$c=f$ then joint frequency data is un-normalized

$c$ icdf $=t$ then cumulative distribution file created (CDF.OUT)

$c \quad=f$ then no cumulative distribution file created

$c$ ichk $=t$ then $X / Q$ parameter print option turned on

$c \quad=f$ then no parameter print

$c$ isite $=t$ then $X / Q$ based on joint frequency data for all 16 sectors

$c=f$ then $X / Q$ based on joint frequency data of individual sectors

$c$ ipop $=t$ then $X / Q$ is population weighted

$c . \quad=f$ then no population weighting

$c i c o n=t$ then $X / Q$ is air concentration

$c=f$ then $X / Q$ is integrated exposure

C

c MODEL CHOICES:

c idep iwake ipm irise igrav iwash iflow iwind 


\section{$\begin{array}{llllllll}0 & 0 & 0 & 0 & 0 & 0 & 0 & 0\end{array}$}

$c$ idep $=1$ then plume depletion model turned on (Chamberlain mode1)

c iwake $=1$ then NRC RG 1.145 building wake model turned on

c $\quad=2$ then MACCS virtual distance building wake model turned on

c $\mathrm{ipm}=1$ then NRC RG 1.145 plume meander model turned on

$c \quad=2$ then 5th Power Law plume meander model turned on

$c \quad=3$ then sector average model turned on

c irise $=1$ then momentum/buoyancy plume rise model turned on, buoyancy rise based on sensible heat emission

$=2$ then momentum/buoyancy plume rise model turned on, buoyancy rise based on initial plume density

igrav = 1 then gravitational settling model turned on

iwash $=1$ then stack downwash mode 1 turned on

iflow $=1$ then sigmas adjusted for volume flow rate

iwind $=1$ then wind speed corrected for plume height

c $=0$ to turn any of the above models off

C

c PARAMETER INPUT:

C stack wind

c release speed

$c$ height height

c (m)

mixing

height

frequency
(m)
0.000
(m)
1. $00000 E+03$
(\%)

to

exceed

5. $00000 E+00$

scaling

factor

c

c

building

width

c (m)

7. $90000 \mathrm{E}+00$

building

height

(m)

3. $00000 E+00$

release

duration

(hr)

$1.00000 \mathrm{E}+00$

initial

initial

plume

plume

density

flow

rate

$(\mathrm{g} / \mathrm{cc})$

(m3/s)

stack

diameter

1.22000E-03

$7.07000 \mathrm{E}+00$

(m)

3. $00000 E+00$

(?)

1. $00000 E+00$

gravitational

deposition

velocity.

settling

velocity

$(\mathrm{m} / \mathrm{s})$

$(\mathrm{m} / \mathrm{s})$

1.00000E-03

1.00000E-03

sensible

heat

emission

rate

(cal $/ \mathrm{s})$

$4.18000 \mathrm{E}+05$

c RECEPTOR DEPENDENT DATA

C FOR MODE make

c 1 (site specific)

RECEPTOR DEPENDENT DATA

c 2 (by class \& wind speed)

c 3 (create plot file)

sector distance $z$-height

class windspeed distance offset z-height

C

C RECEPTOR PARAMETER DESCRIPTION:

c sector $=0,1,2 \ldots($ al1, S, SSW, etc. $)$

c distance $=$ meters

c class $=1,2,3,4,5,6,7$ (P-G stability class $A, B, C, D, E, F, G$ )

$c$ windspeed $=\mathrm{m} / \mathrm{s}$

$c$ offset $=$ meters offset from plume centerline

c $x \max =$ maximum distance to plot or calculate to (m)

$c$ imax $=$ distance intervals

c $y \max =$ maximum offset to $\mathrm{p}$ lot $(\mathrm{m})$ 
$c$ jmax $=$ offset intervals

c $x q m i n=$ minimum scaled $X / Q$ to calculate

$c$ power $=$ exponent in power function step size

MODE:

Site specific $X / Q$ calculated

LOGICAL CHOICES:

Joint frequency used to calculate $X / Q$ based on frequency of exceedance.

No normalization of joint frequency.

$X / Q$ calculated for overall site.

Output is atmospheric dispersion coefficient.

MODELS SELECTED:

WARNING/ERROR MESSAGES:

WARNING \#3 - Scaled X/Q units (shown as $\mathrm{s} / \mathrm{m} 3$ or $1 / \mathrm{m} 3$ below) do not reflect the user specified scaling factor.

JOINT FREQUENCY DATA:

200 AREA (HMS) - 10 M - Pasqui11 A - G (1983 - 1991 Average)

Created $8 / 26 / 92$ KR

Overall Site X/Qs for Tank 104-AN Hydrogen Burn

\begin{tabular}{|c|c|c|c|c|c|c|c|c|}
\hline SECTOR & $\begin{array}{l}\text { DISTANCE } \\
(\mathrm{m})\end{array}$ & $\begin{array}{l}\text { RECEPT } \\
\text { HEIGHT } \\
(\mathrm{m})\end{array}$ & $\begin{array}{c}\text { SECT. } \\
\text { FREQ. } \\
(\%)\end{array}$ & POPULATION & $\begin{array}{c}\text { TOTAL } \\
\text { POPULATION } \\
\text { SCALED } \\
X / Q \\
(\mathrm{~s} / \mathrm{m} 3)\end{array}$ & $\begin{array}{c}\text { AVERAGE } \\
\text { INDIVIDUAL } \\
\text { SCALED } \\
X / Q \\
(\mathrm{~s} / \mathrm{m} 3)\end{array}$ & $\begin{array}{l}\text { ATM. } \\
\text { STAB. } \\
\text { CLASS }\end{array}$ & $\begin{array}{l}\text { WIND } \\
\text { SPEED } \\
(\mathrm{m} / \mathrm{s})\end{array}$ \\
\hline $\begin{array}{l}\overline{A L L} \\
\text { ALL }\end{array}$ & $\begin{array}{r}100 \\
21100\end{array}$ & 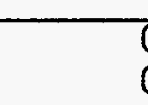 & $\begin{array}{l}99.94 \\
99.94\end{array}$ & $\begin{array}{l}1 \\
1\end{array}$ & $\begin{array}{l}3.44 E-02 \\
9.87 E-06\end{array}$ & $\begin{array}{l}3.44 \mathrm{E}-02 \\
9.87 \mathrm{E}-06\end{array}$ & $\begin{array}{l}\bar{F} \\
G\end{array}$ & $\begin{array}{r}.89 \\
2.65\end{array}$ \\
\hline
\end{tabular}


WHC-SD-WM-SAR-064, Rev. 0

\author{
GENII Input File \\ Onsite Receptor at $100 \mathrm{~m}$ \\ Best Estimate Release
}

\#\#\#\#\#\#\#\#\#\#\#\#\#\#\#\#\#\#\#\#\# Program GENII Input File \#\#\#\#\#\#\#\#\#\# 8 Jul 88 \#\#\#\# Tit7e: 104-AN hydrogen burn - best estimate source term - OS 100m $\backslash$ GENII $\backslash 104$ anlos in

Created on 04-01-1994 at 09:55

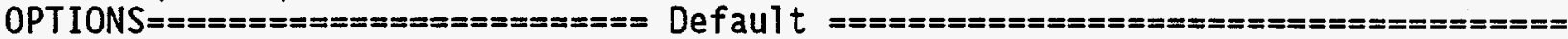

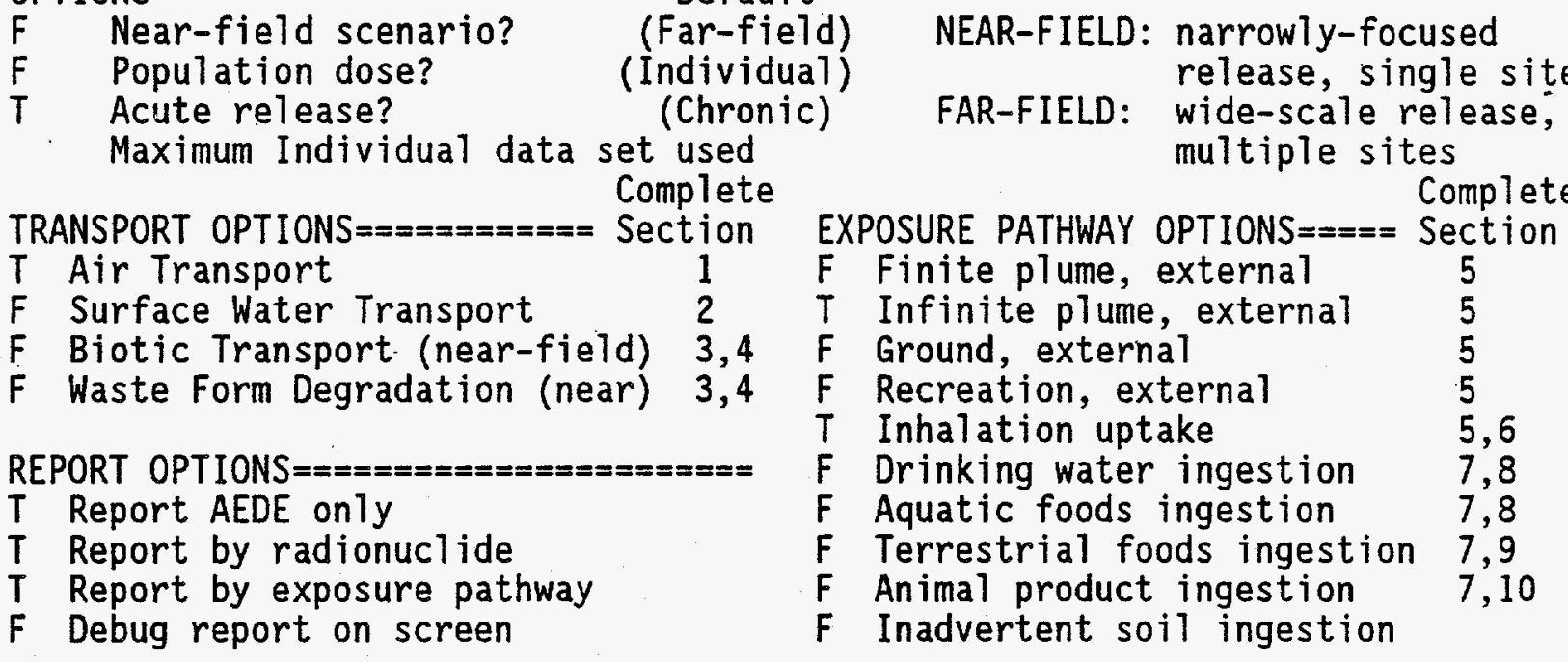

INVENTORY \#\#\#\#\#\#\#\#\#\#\#\#\#\#\#\#\#\#\#\#\#\#\#\#\#\#\#\#\#\#\#\#\#\#\#\#\#\#\#\#\#\#\#\#\#\#\#\#\#\#\#\#\#\#\#\#\#\#\#\#\#\#\#

4 Inventory input activity units: (1-pCi $2-u C i \quad 3-m C i \quad 4-C i \quad 5-B q)$

0 Surface soil source units (1- m2 2- m3 $3-\mathrm{kg})$

Equilibrium question goes here

\begin{tabular}{|c|c|c|c|c|c|c|c|c|}
\hline Use when & transf & port sel & cted & & leld & nar & option & \\
\hline $\begin{array}{l}\text { Release } \\
\text { Radio- } \\
\text { nuclide }\end{array}$ & $\begin{array}{l}\text { Air } \\
/ y r\end{array}$ & $\begin{array}{l}\text { Surface } \\
\text { Water } \\
\text { /yr }\end{array}$ & $\begin{array}{l}\text { Buried } \\
\text { Waste } \\
\text { /m3 }\end{array}$ & $\begin{array}{l}\text { Air } \\
\text { /m3 }\end{array}$ & $\begin{array}{l}\text { Surface } \\
\text { Soil } \\
\text { /unit }\end{array}$ & $\begin{array}{l}\text { Deep } \\
\text { So i } 1 \\
/ \mathrm{m} 3\end{array}$ & $\begin{array}{l}\text { Ground } \\
\text { Water } \\
/ L\end{array}$ & $\begin{array}{l}\text { Surface } \\
\text { Water } \\
/ L\end{array}$ \\
\hline $\begin{array}{l}\text { SR90 } \\
Y \quad 90 \\
\text { TC99 } \\
I \quad 129 \\
\text { CS137 } \\
\text { NP237 } \\
\text { PU239 } \\
\text { AM241 }\end{array}$ & $\begin{array}{l}7.5 \mathrm{E}-03 \\
7.5 \mathrm{E}-03 \\
1.6 \mathrm{E}-03 \\
6.5 \mathrm{E}-05 \\
3.7 \mathrm{E}-01 \\
1.2 \mathrm{E}-04 \\
1.7 \mathrm{E}-05 \\
2.5 \mathrm{E}-04\end{array}$ & & & & & & & \\
\hline
\end{tabular}

\begin{tabular}{l|ll|} 
Use when & $\begin{array}{r}\text { measured values are known } \\
\text { mearived Concentrations--- }\end{array}$ \\
\hline Release & Terres. Animal Drink Aquatic \\
Radio- & Plant Product Water & Food
\end{tabular}


WHC-SD-WM-SAR-064, Rev。 0

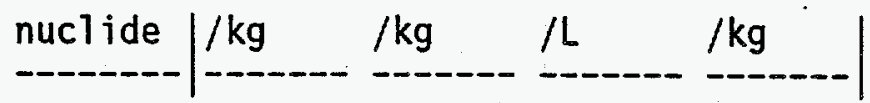

TIME \#\#\#\#\#\#\#\#\#\#\#\#\#\#\#\#\#\#\#\#\#\#\#\#\#\#\#\#\#\#\#\#\#\#\#\#\#\#\#\#\#\#\#\#\#\#\#\#\#\#\#\#\#\#\#\#\#\#\#\#\#\#\#\#\#\#\#\#\#\#

$1 \quad$ Intake ends after (yr)

50 Dose calc. ends after (yr)

0 Release ends after (yr)

0 No. of years of air deposition prior to the intake period

0 No. of years of irrigation water deposition prior to the intake period

FAR-FIELD SCENARIOS (IF POPULATION DOSE) \#\#\#\#\#\#\#\#\#\#\#\#\#\#\#\#\#\#\#\#\#\#\#\#\#\#\#\#\#\#\#\#

0 Definition option: 1-Use population grid in file POP.IN

0

2-Use total entered on this line

NEAR-FIELD SCENARIOS $\# \# \# \# \# \# \# \# \# \# \# \# \# \# \# \# \# \# \# \# \# \# \# \# \# \# \# \# \# \# \# \# \# \# \# \# \# \# \# \# \# \# \# \# \# \# \# \# \# \# \# \# \# \# \#$

Prior to the beginning of the intake period: (yr)

0

0

0

0

0

0

TRANSPORT

$3.44 \mathrm{E}-2$

0

0

$\mathrm{F}$

0

0

0

0

0

0

0

0

0

0

$3.44 \mathrm{E}-2$
0

When was the inventory disposed? (Package degradation starts)

When was LOIC? (Biotic transport starts)

Fraction of roots in upper soil (top $15 \mathrm{~cm}$ )

Fraction of roots in deep soil

Manual redistribution: deep soil/surface soil dilution factor

Source area for external dose modification factor (m2)

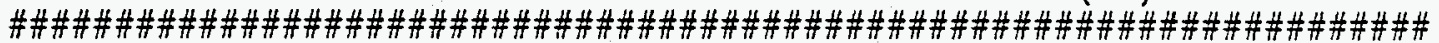

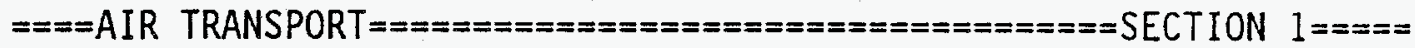
0 -Calculate PM

Option: 1-Use chi/Q or PM value F 2-Select MI dist \& dir 0 3-Specify MI dist \& dir 0 Chi/Q or PM value MI sector index $(1=S)$ Release type (0-3) Stack release (T/F) Stack height $(\mathrm{m})$ Stack flow $(\mathrm{m} 3 / \mathrm{sec})$ MI distance from release point (m) 0 Use jf data, (T/F) else chi/Q grid|0

Stack radius (m) Effluent temp. (C) Building $x$-section ( $m 2$ ) Building height $(\mathrm{m})$

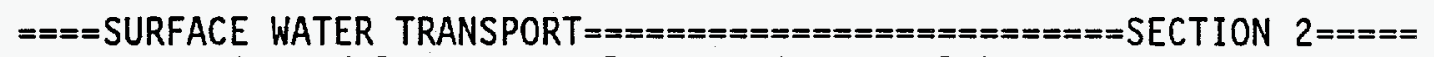
Mixing ratio model: 0-use value, 1-river, 2-lake Mixing ratio, dimensionless

Average river flow rate for: MIXFLG $=0(\mathrm{~m} 3 / \mathrm{s}), \operatorname{MIXFLG}=1,2(\mathrm{~m} / \mathrm{s})$, Transit time to irrigation withdrawl location (hr)

If mixing ratio model $>0$ :

Rate of effluent discharge to receiving water body $(\mathrm{m} 3 / \mathrm{s})$ Longshore distance from release point to usage location (m) Offshore distance to the water intake (m) Average water depth in surface water body (m) Average river width (m), MIXFLG $=1$ only Depth of effluent discharge point to surface water $(m)$, lake only

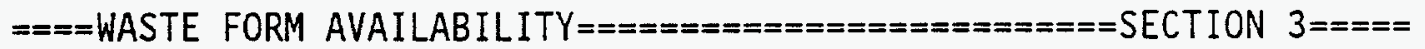
Waste form/package half life, (yr) Waste thickness, (m) 
Depth of soil overburden, $m$

$===$ BIOTIC TRANSPORT OF BURIED SOURCE $==============$ SECTION $4=====$ Consider during inventory decay/buildup period (T/F)?

Consider during intake period (T/F)? 1-Arid non agricultural

Pre-Intake site condition............. 2-Humid non agricultural

3-Agricul tural

EXPOSURE \#\#\#\#\#\#\#\#\#\#\#\#\#\#\#\#\#\#\#\#\#\#\#\#\#\#\#\#\#\#\#\#\#\#\#\#\#\#\#\#\#\#\#\#\#\#\#\#\#\#\#\#\#\#\#\#\#\#\#\#\#\#\#\#\#

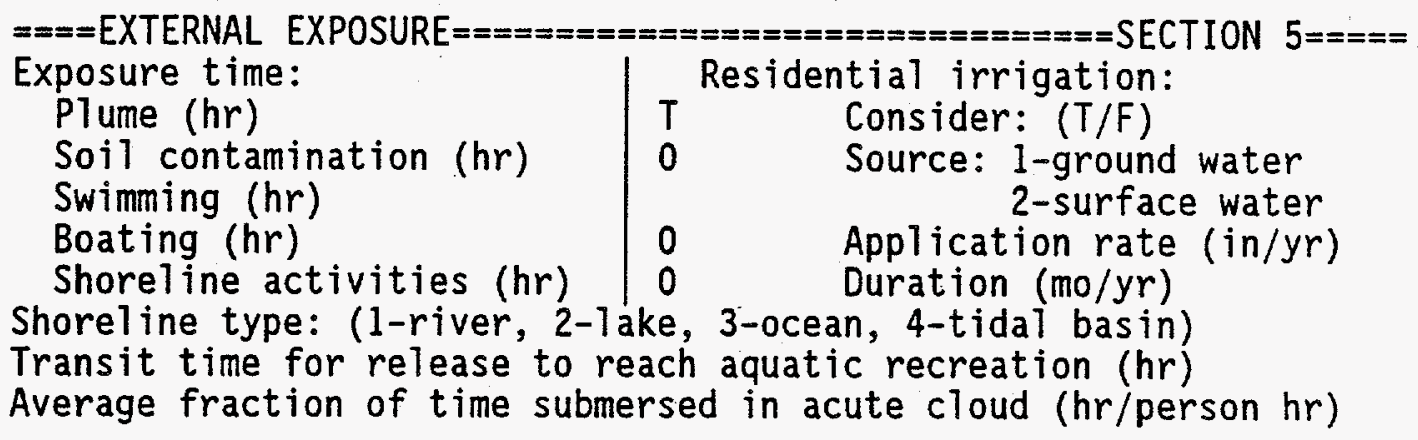

8766.0

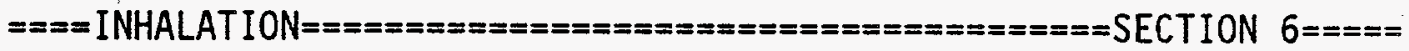
Hours of exposure to contamination per year

0

0

0 -No resus- .1-Use Mass Loading

pension Mass loading factor $(\mathrm{g} / \mathrm{m} 3)$ Top soil available $(\mathrm{cm})$

$====$ INGESTION POPULATION $==========================$ SECTION $7=====$

Atmospheric production definition (select option):

0 -Use food-weighted chi/Q, (food-sec/m3), enter value on this line

1-Use population-weighted chi/Q

2-Use uniform production

3-Use chi/Q and production grids (PRODUCTION will be overridden)

0

0

F

Population ingesting aquatic foods, 0 defaults to total (person)

Population ingesting drinking water, 0 defaults to total (person)

Consider dose from food exported out of region (defaul $t=F$ )

Note below: $S^{*}$ or Source: 0-none, 1-ground water, 2-surface water 3-Derived concentration entered above

$====$ AQUATIC FOODS / DRINKING WATER INGESTION========SECTION $8====$

Salt water? (default is fresh)

\begin{tabular}{|c|c|c|c|c|c|c|c|}
\hline $\begin{array}{l}\text { USE } \\
? \\
T / F\end{array}$ & $\begin{array}{l}\text { FOOD } \\
\text { TYPE }\end{array}$ & $\begin{array}{l}\text { TRAN- } \\
\text { SIT } \\
\mathrm{hr}\end{array}$ & $\begin{array}{l}\text { PROD- } \\
\text { UCTION } \\
\mathrm{kg} / \mathrm{yr}\end{array}$ & $\begin{array}{l}\text {-CONSUMP } \\
\text { HOLDUP } \\
\text { da }\end{array}$ & $\begin{array}{l}\text { PTION- } \\
\text { RATE } \\
\mathrm{kg} / \mathrm{yr}\end{array}$ & & DRINKING WATER \\
\hline F & $\begin{array}{l}\text { FISH } \\
\text { MOLLUS } \\
\text { CRUSTA } \\
\text { PLANTS }\end{array}$ & $\begin{array}{l}0.00 \\
0.00 \\
0.00 \\
0.00\end{array}$ & $\begin{array}{l}0.0 \mathrm{E}+00 \\
0.0 \mathrm{E}+00 \\
0.0 \mathrm{E}+00 \\
0.0 \mathrm{E}+00\end{array}$ & $\begin{array}{l}0.00 \\
0.00 \\
0.00 \\
0.00\end{array}$ & $\begin{array}{l}0.0 \\
0.0 \\
0.0 \\
0.0\end{array}$ & $\begin{array}{l}0 \\
\mathrm{~T} \\
0 \\
0\end{array}$ & $\begin{array}{l}\text { Source (see above) } \\
\text { Treatment? T/F } \\
\text { Holdup/transit(da) } \\
\text { Consumption (L/yr) }\end{array}$ \\
\hline
\end{tabular}

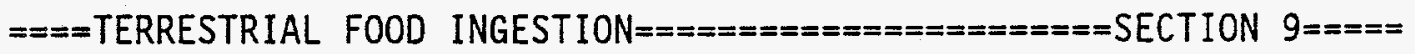


WHC-SD-WM-SAR-064, Rev. 0

\begin{tabular}{|c|c|c|c|c|c|c|c|c|}
\hline $\begin{array}{l}\text { USE } \\
\stackrel{?}{\text { T/F }}\end{array}$ & $\begin{array}{l}\text { FOOD } \\
\text { TYPE }\end{array}$ & $\begin{array}{l}\text { GROW } \\
\text { TIME } \\
\text { da }\end{array}$ & $\begin{array}{l}\text {--IRRIGA } \\
\text { S RATE } \\
\text { * in/yr }\end{array}$ & $\begin{array}{l}\text { TION-- } \\
\text { TIME } \\
\text { mo/yr }\end{array}$ & $\begin{array}{l}\text { YIEL.D } \\
\mathrm{kg} / \mathrm{m} 2\end{array}$ & $\begin{array}{l}\text { PROD- } \\
\text { UCTION } \\
\mathrm{kg} / \mathrm{yr}\end{array}$ & $\begin{array}{l}\text {--CONSUM } \\
\text { HOLDUP } \\
\text { da }\end{array}$ & $\begin{array}{l}\text { PTION-- } \\
\text { RATE } \\
\mathrm{kg} / \mathrm{yr}\end{array}$ \\
\hline $\begin{array}{l}F \\
F \\
F \\
F\end{array}$ & $\begin{array}{l}\text { LEAF } V \\
\text { ROOT V } \\
\text { FRUIT } \\
\text { GRAIN }\end{array}$ & $\begin{array}{l}0.00 \\
0.00 \\
0.00 \\
0.00\end{array}$ & $\begin{array}{l}0.0 \\
0.0 \\
0.0 \\
0.0\end{array}$ & $\begin{array}{l}0.0 \\
0.0 \\
0.0 \\
0.0\end{array}$ & $\begin{array}{l}0.0 \\
0.0 \\
0.0 \\
0.0\end{array}$ & $\begin{array}{l}0.0 E+00 \\
0.0 E+00 \\
0.0 E+00 \\
0.0 E+00\end{array}$ & $\begin{array}{l}0.0 \\
0.0 \\
0.0 \\
0.0\end{array}$ & $\begin{array}{l}0.0 \\
0.0 \\
0.0 \\
0.0\end{array}$ \\
\hline
\end{tabular}

\begin{tabular}{|c|c|c|c|c|c|c|c|c|c|}
\hline $\begin{array}{ll}\text { USE } & \\
\stackrel{?}{T} & \text { FOOD } \\
\text { T/F } & \text { TYPE }\end{array}$ & $\begin{array}{l}--- \text { HUMAN---- } \\
\text { CONSUMPTION } \\
\text { RATE HOLDUP } \\
\mathrm{kg} / \mathrm{yr} \mathrm{da}\end{array}$ & $\begin{array}{l}\text { TOTAL } \\
\text { PROD- } \\
\text { UCTION } \\
\mathrm{kg} / \mathrm{yP}\end{array}$ & $\begin{array}{l}\text { DRINK } \\
\text { WATER } \\
\text { CONTAM } \\
\text { FRACT. }\end{array}$ & $\begin{array}{l}\text { DIET } \\
\text { FRAC- } \\
\text { TION }\end{array}$ & $\begin{array}{l}\text { GROW } \\
\text { TIME } \\
\text { da }\end{array}$ & $\begin{array}{l}\text { - STORED } \\
\text {-IRRIGA } \\
\text { S RATE } \\
\text { * in/yr }\end{array}$ & $\begin{array}{l}\text { FEED-- } \\
\text { ATION-- } \\
\text { TIME } \\
\mathrm{mo} / \mathrm{yr}\end{array}$ & $\begin{array}{l}\text { YIELD } \\
\mathrm{kg} / \mathrm{m} 3\end{array}$ & $\begin{array}{l}\text { STOR- } \\
\text { AGE } \\
\text { da }\end{array}$ \\
\hline $\begin{array}{l}\text { BEEF } \\
\text { POULTR } \\
\text { MILK } \\
\text { EGG }\end{array}$ & $\begin{array}{l}0.0 \\
0.0 \\
0.0 \\
0.0\end{array}$ & $\begin{array}{l}0.00 \\
0.00 \\
0.00 \\
0.00\end{array}$ & $\begin{array}{l}0.00 \\
0.00 \\
0.00 \\
0.00\end{array}$ & $\begin{array}{l}0.00 \\
0.00 \\
0.00 \\
0.00\end{array}$ & $\begin{array}{l}0.0 \\
0.0 \\
0.0 \\
0.0\end{array}$ & $\begin{array}{ll}0 & 0.0 \\
0 & 0.0 \\
0 & 0.0 \\
0 & 0.0\end{array}$ & $\begin{array}{l}0.00 \\
0.00 \\
0.00 \\
0.00\end{array}$ & $\begin{array}{l}0.00 \\
0.00 \\
0.00 \\
0.00\end{array}$ & $\begin{array}{l}0.0 \\
0.0 \\
0.0 \\
0.0\end{array}$ \\
\hline $\begin{array}{l}\text { BEEF } \\
\text { MILK }\end{array}$ & & & & 0.00 & $\begin{array}{l}0.0 \\
0.0\end{array}$ & $\begin{array}{l}0 \\
0\end{array}$ & $\begin{array}{l}0.00 \\
0.00\end{array}$ & $\begin{array}{l}0.00 \\
0.00\end{array}$ & $\begin{array}{l}0.0 \\
0.0\end{array}$ \\
\hline
\end{tabular}




\section{GENII Input File \\ Ingestion Pathway Receptor $15.9 \mathrm{~km} \mathrm{E}$ \\ Bounding Release}

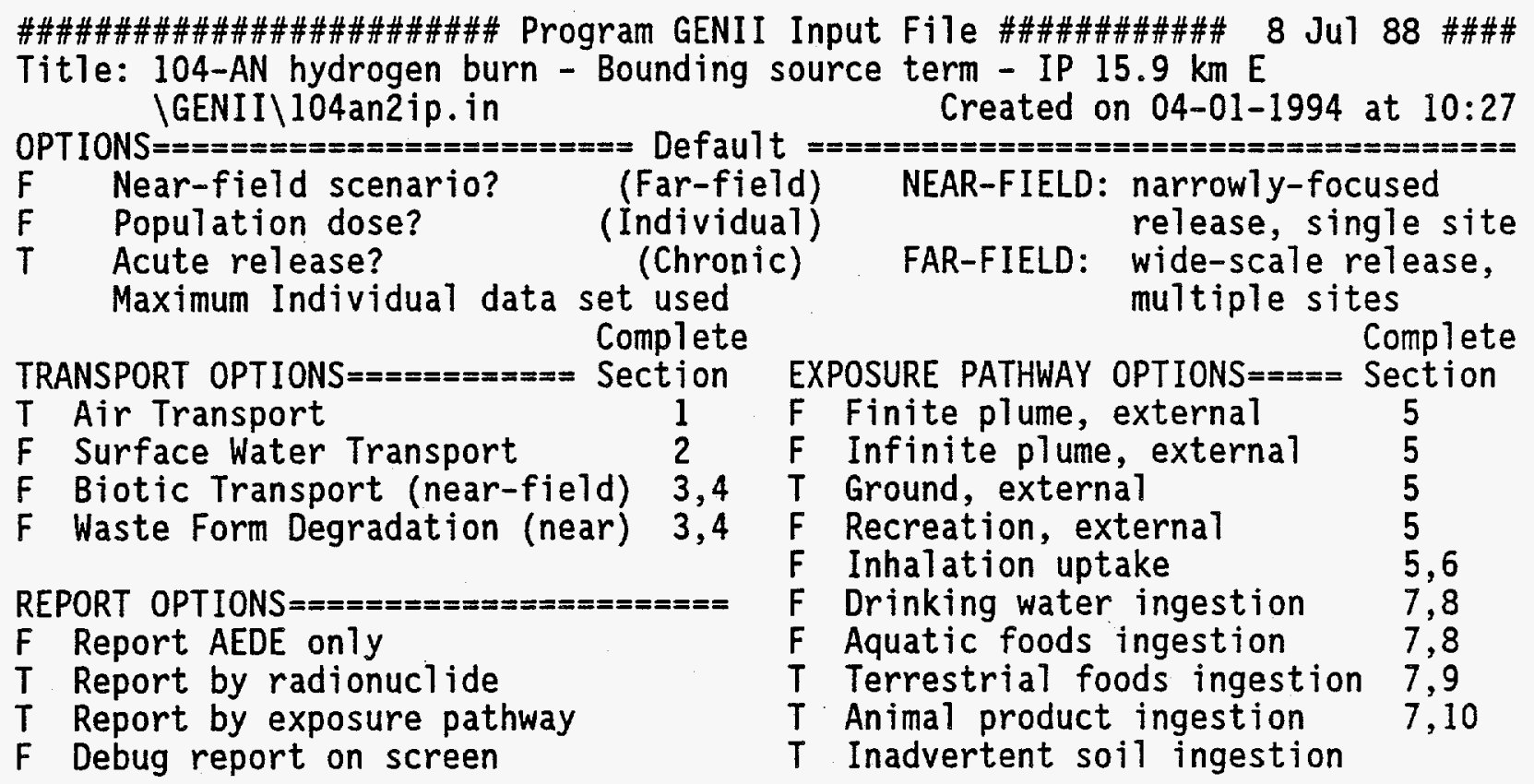

INVENTORY \#\#\#\#\#\#\#\#\#\#\#\#\#\#\#\#\#\#\#\#\#\#\#\#\#\#\#\#\#\#\#\#\#\#\#\#\#\#\#\#\#\#\#\#\#\#\#\#\#\#\#\#\#\#\#\#\#\#\#\#\#\#\#\#\#

4 Inventory input activity units: (1-pCi $2-u C i$ 3-mCi $4-C i \quad 5-B q)$

0 Surface soil source units $(1-\mathrm{m} 2 \quad 2-\mathrm{m} 33-\mathrm{kg})$

Equilibrium question goes here

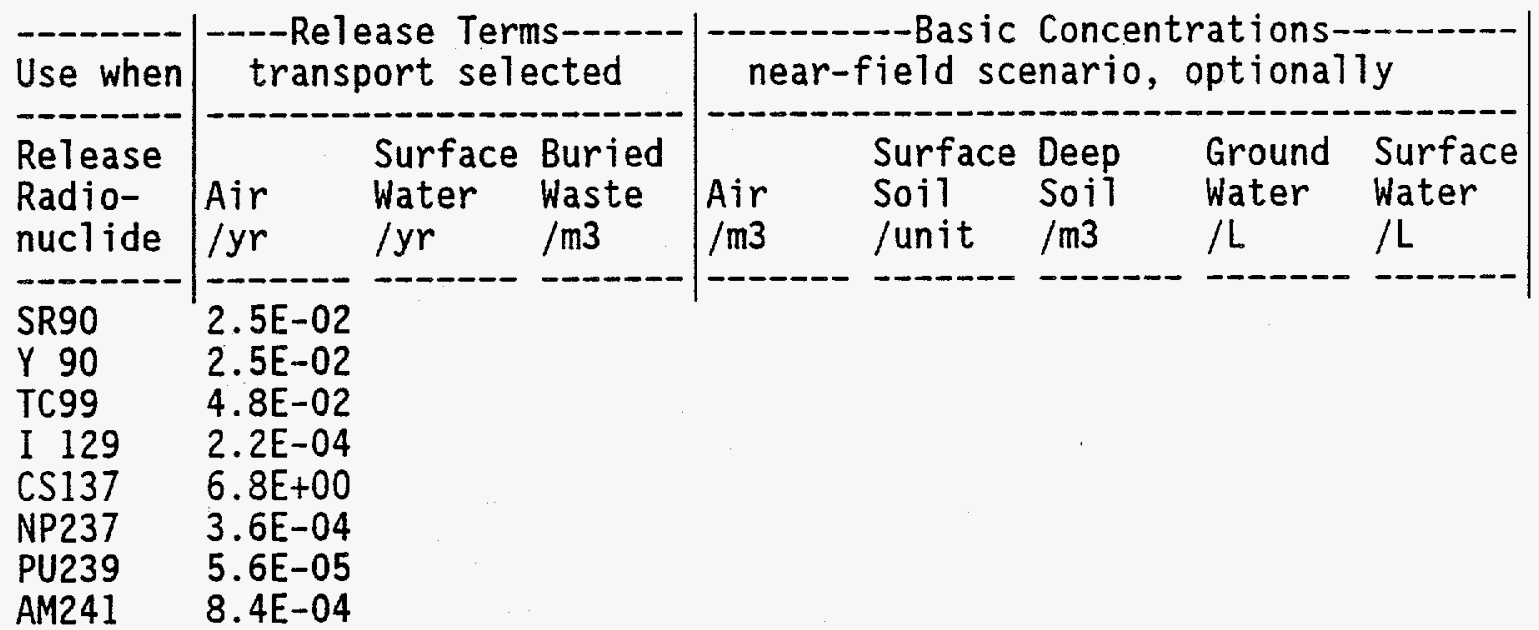

\begin{tabular}{l|lll} 
Use when & --- Derived Concentrations----- \\
\hline measured values are known & \\
\hline Release & Terres. Animal Drink & Aquatic \\
Radio- & Plant Product Water & Food
\end{tabular}


WHC-SD-WM-SAR-064, Rev。O

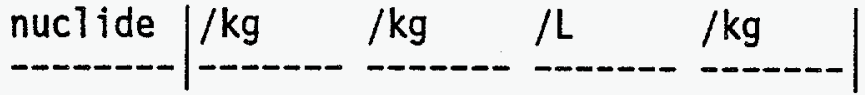

TIME \#\#\#\#\#\#\#\#\#\#\#\#\#\#\#\#\#\#\#\#\#\#\#\#\#\#\#\#\#\#\#\#\#\#\#\#\#\#\#\#\#\#\#\#\#\#\#\#\#\#\#\#\#\#\#\#\#\#\#\#\#\#\#\#\#\#\#\#

50 Intake ends after (yr)

50 Dose calc. ends after (yr)

$0 \quad$ Release ends after (yr)

0 No. of years of air deposition prior to the intake period

0 No. of years of irrigation water deposition prior to the intake period

FAR-FIELD SCENARIOS (IF POPULATION DOSE) \#\#\#\#\#\#\#\#\#\#\#\#\#\#\#\#\#\#\#\#\#\#\#\#\#\#\#\#\#\#\#\#\#\#

0 Definition option: 1-Use population grid in file POP. IN

0

2-Use total entered on this line

NEAR-FIELD SCENARIOS \#\#\#\#\#\#\#\#\#\#\#\#\#\#\#\#\#\#\#\#\#\#\#\#\#\#\#洋\#\#\#\#\#\#\#\#\#\#\#\#\#\#\#\#\#\#\#\#\#\#\#\#\#\#

Prior to the beginning of the intake period: $(y r)$

0 When was the inventory disposed? (Package degradation starts)

$0 \quad$ When was LOIC? (Biotic transport starts)

$0 \quad$ Fraction of roots in upper soil (top $15 \mathrm{~cm}$ )

$0 \quad$ Fraction of roots in deep soil

0 Manual redistribution: deep soil/surface soil dilution factor

0 Source area for external dose modification factor (m2)

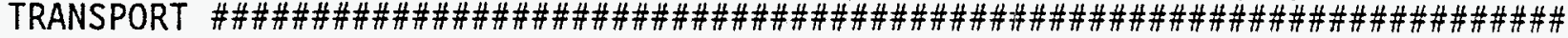

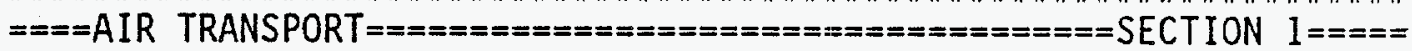

O-Calculate PM $\quad \begin{array}{ll}0 & \text { Release type }(0-3)\end{array}$

1 Option: 1-Use chi/Q or PM value $\quad F \quad$ Stack release (T/F)

2-Select MI dist \& dir $00 \quad$ Stack height (m)

3-Specify MI dist \& dir 0 Stack flow $(\mathrm{m} 3 / \mathrm{sec})$

1.45E-5 Chi/Q or PM value

MI sector index ( $1=S) \quad 0 \quad$ Effluent temp. (C)

MI distance from release point (m) 0 Building $x$-section (m2)

Use jf data, (T/F) else chi/Q grid|0 Building height (m)

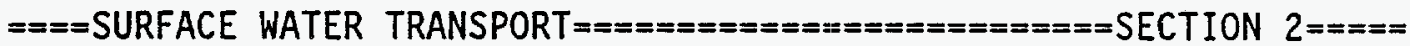
Mixing ratio model: 0-use value, 1-river, 2-lake

Mixing ratio, dimensionless

Average river flow rate for: $M I X F L G=0(\mathrm{~m} 3 / \mathrm{s}), M I X F L G=1,2(\mathrm{~m} / \mathrm{s})$,

Transit time to irrigation withdrawl location (hr)

If mixing ratio model $>0$ :

Rate of effluent discharge to receiving water body (m3/s)

Longshore distance from release point to usage location (m)

offshore distance to the water intake (m)

Average water depth in surface water body (m)

Average river width (m), MIXFLG=1 only

Depth of effluent discharge point to surface water (m), Take only

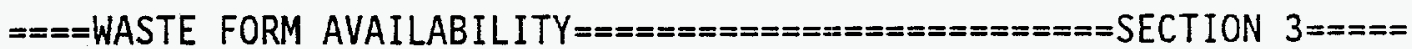
Waste form/package half life, (yr)

Waste thickness, (m) 
$\mathrm{T}$

0

Depth of soil overburden, $m$

$====$ BIOTIC TRANSPORT OF BURIED SOURCE $================$ SECTION $4=====$ Consider during inventory decay/buildup period (T/F)?

Consider during intake period $(T / F)$ ? |1-Arid non agricultural

Pre-Intake site condition............ 2-Humid non agricultural 3-Agricultural

EXPOSURE \#\#\#\#\#\#\#\#\#\#\#\#\#\#\#\#\#\#\#\#\#\#\#\#\#\#\#\#\#\#\#\#\#\#\#\#\#\#\#\#\#\#\#\#\#\#\#\#\#\#\#\#\#\#\#\#\#\#\#\#\#\#\#\#\#\#

0

4380.0

0

0

0

0

0

1.0

8766.0

0

0

0

0

0

$\mathrm{F}$

$\mathrm{F}$

$=$ SECTION $5=====$

Exposure time:

P7ume (hr)

Soil contamination (hr)

Swimming (hr)

Boating ( $h r$ )

Shoreline activities (hr) 0

Residential irrigation:

Consider: ( $T / F)$

Source: 1-ground water

2-surface water

Application rate (in/yr)

Duration (mo/yr)

Shoreline type: (1-river, 2-lake, 3-ocean, 4-tidal basin)

Transit time for release to reach aquatic recreation (hr)

Average 'fraction of time submersed in acute cloud (hr/person hr)

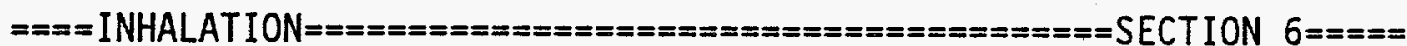

Hours of exposure to contamination per year

0-No resus- 1-Use Mass Loading 2-Use Anspaugh model

pension Mass loading factor $(\mathrm{g} / \mathrm{m} 3)$ Top soil available $(\mathrm{cm})$

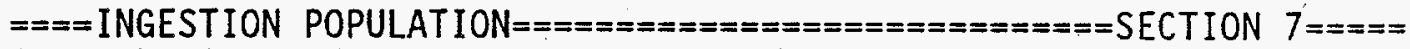
Atmospheric production definition (select option):

0 -Use food-weighted chi/Q, (food-sec/m3), enter value on this line

1-Use population-weighted chi/Q

2-Use uniform production

3-Use chi/Q and production grids (PRODUCTION will be overridden)

Population ingesting aquatic foods, 0 defaults to total (person)

Population ingesting drinking water, 0 defaults to total (person)

Consider dose from food exported out of region (default=F)

Note below: $S^{*}$ or Source: 0-none, 1-ground water, 2-surface water

3-Derived concentration entered above

$====$ AQUATIC FOODS / DRINKING WATER INGESTION $========$ SECTION $8====$

Salt water? (default is fresh)

\begin{tabular}{|c|c|c|c|c|c|c|}
\hline $\begin{array}{ll}\text { USE } & \\
\stackrel{?}{T} / F & \text { FOOD } \\
\text { TYPE }\end{array}$ & $\begin{array}{l}\text { TRAN- } \\
\text { SIT } \\
h r\end{array}$ & $\begin{array}{l}\text { PROD- } \\
\text { UCTION } \\
\mathrm{kg} / \mathrm{yr}\end{array}$ & $\begin{array}{l}\text { - CONSUM } \\
\text { HOLDUP } \\
\text { da }\end{array}$ & $\begin{array}{l}\text { TION- } \\
\text { RATE } \\
\mathrm{kg} / \mathrm{yr}\end{array}$ & & RINKING WATER \\
\hline $\begin{array}{l}\text { FISH } \\
\text { MOLLUS } \\
\text { CRUSTA } \\
\text { PLANTS }\end{array}$ & $\begin{array}{l}0.00 \\
0.00 \\
0.00 \\
0.00\end{array}$ & $\begin{array}{l}0.0 E+00 \\
0.0 E+00 \\
0.0 E+00 \\
0.0 E+00\end{array}$ & $\begin{array}{l}0.00 \\
0.00 \\
0.00 \\
0.00\end{array}$ & $\begin{array}{l}0.0 \\
0.0 \\
0.0 \\
0.0\end{array}$ & $\begin{array}{l}0 \\
T \\
0 \\
0\end{array}$ & $\begin{array}{l}\text { Source (see above) } \\
\text { Treatment? T/F } \\
\text { Holdup/transit(da) } \\
\text { Consumption (L/yr) }\end{array}$ \\
\hline
\end{tabular}

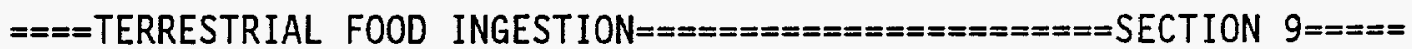




\begin{tabular}{|c|c|c|c|c|c|c|c|c|}
\hline \multirow{2}{*}{$\begin{array}{l}\text { USE } \\
? \\
\mathrm{~T} / \mathrm{F}\end{array}$} & \multirow[b]{2}{*}{$\begin{array}{l}\text { FOOD } \\
\text { TYPE }\end{array}$} & \multirow{2}{*}{$\begin{array}{l}\text { GROW } \\
\text { TIME } \\
\text { da }\end{array}$} & \multicolumn{2}{|c|}{--IRRIGATION-- } & \multirow[b]{2}{*}{$\begin{array}{l}\text { YIEL.D } \\
\mathrm{kg} / \mathrm{mL} 2\end{array}$} & \multirow{2}{*}{$\begin{array}{l}\text { PROD- } \\
\text { UCTION } \\
\mathrm{kg} / \mathrm{yr}\end{array}$} & \multicolumn{2}{|c|}{--CONSUMPTION-- } \\
\hline & & & $\begin{array}{l}\text { S RATE } \\
\text { * in/yr }\end{array}$ & $\begin{array}{l}\text { TIME } \\
\text { mo/yr }\end{array}$ & & & $\begin{array}{l}\text { HOLDUP } \\
\text { da }\end{array}$ & $\begin{array}{l}\text { RATE } \\
\mathrm{kg} / \mathrm{yr}\end{array}$ \\
\hline $\begin{array}{l}T \\
T \\
T \\
T\end{array}$ & $\begin{array}{l}\text { LEAF V } \\
\text { ROOT V } \\
\text { FRUIT } \\
\text { GRAIN }\end{array}$ & $\begin{array}{l}90.00 \\
90.00 \\
90.00 \\
90.00\end{array}$ & $\begin{array}{l}0.0 \\
0.0 \\
0.0 \\
0.0\end{array}$ & $\begin{array}{l}0.0 \\
0.0 \\
0.0 \\
0.0\end{array}$ & $\begin{array}{l}1.5 \\
4.0 \\
2.0 \\
0.8\end{array}$ & $\begin{array}{l}0.0 \mathrm{E}+00 \\
0.0 \mathrm{E}+00 \\
0.0 \mathrm{E}+00 \\
0.0 \mathrm{E}+00\end{array}$ & $\begin{array}{r}1.0 \\
5.0 \\
5.0 \\
180.0\end{array}$ & $\begin{array}{r}30.0 \\
220.0 \\
330.0 \\
80.0\end{array}$ \\
\hline
\end{tabular}

\begin{tabular}{|c|c|c|c|c|c|c|c|c|c|c|c|}
\hline \multirow[b]{2}{*}{$\begin{array}{l}\text { USE } \\
? \\
\text { T/F }\end{array}$} & \multirow[b]{2}{*}{$\begin{array}{l}\text { FOOD } \\
\text { TYPE }\end{array}$} & \multicolumn{2}{|c|}{---HUMAN---- } & \multirow{2}{*}{$\begin{array}{l}\text { TOTAL } \\
\text { PROD- } \\
\text { UCTION } \\
\mathrm{kg} / \mathrm{yr}\end{array}$} & \multirow{2}{*}{$\begin{array}{l}\text { DRINK } \\
\text { WATER } \\
\text { CONTAM } \\
\text { FRACT. }\end{array}$} & \multicolumn{6}{|c|}{------------STORED FEED---------- } \\
\hline & & $\begin{array}{l}\text { CONSUM } \\
\text { RATE } \\
\mathrm{kg} / \mathrm{yr}\end{array}$ & $\begin{array}{c}\text { YPTION } \\
\text { HOLDUP } \\
\text { da }\end{array}$ & & & $\begin{array}{l}\text { DIET } \\
\text { FRAC- } \\
\text { TION }\end{array}$ & $\begin{array}{c}\text { GROW } \\
\text { TIME. } \\
\mathrm{da}\end{array}$ & $\begin{array}{l}\text { - IRRIGA } \\
\text { S RATE } \\
\text { * in/yr }\end{array}$ & $\begin{array}{l}\text { TION-- } \\
\text { TIME } \\
\text { mo/yr }\end{array}$ & $\begin{array}{l}\text { YIELD } \\
\mathrm{kg} / \mathrm{m} 3\end{array}$ & $\begin{array}{l}\text { STOR- } \\
\text { AGE } \\
\text { da . }\end{array}$ \\
\hline $\begin{array}{l}T \\
T \\
T\end{array}$ & $\begin{array}{l}\text { BEEF } \\
\text { POULTR } \\
\text { MILK } \\
\text { EGG }\end{array}$ & $\begin{array}{r}80.0 \\
18.0 \\
270.0 \\
30.0\end{array}$ & $\begin{array}{r}15.0 \\
1.0 \\
1.0 \\
1.0\end{array}$ & $\begin{array}{l}0.00 \\
0.00 \\
0.00 \\
0.00\end{array}$ & $\begin{array}{l}0.00 \\
0.00 \\
0.00 \\
0.00\end{array}$ & $\begin{array}{l}0.25 \\
1.00 \\
0.25 \\
1.00\end{array}$ & $\begin{array}{l}90.0 \\
90.0 \\
45.0 \\
90.0\end{array}$ & $\begin{array}{l}0.0 \\
0.0 \\
0.0 \\
0.0\end{array}$ & $\begin{array}{l}0.00 \\
0.00 \\
0.00 \\
0.00\end{array}$ & $\begin{array}{l}0.80 \\
0.80 \\
2.00 \\
0.80\end{array}$ & $\begin{array}{l}0.0 \\
0.0 \\
0.0 \\
0.0\end{array}$ \\
\hline & $\begin{array}{l}\text { BEEF } \\
\text { MILK }\end{array}$ & & & & & $\begin{array}{l}0.75 \\
0.75\end{array}$ & $\begin{array}{l}45.0 \\
30.0\end{array}$ & $\begin{array}{l}0.0 \\
0.0\end{array}$ & $\begin{array}{l}0.00 \\
0.00\end{array}$ & $\begin{array}{l}2.00 \\
1.50\end{array}$ & $\begin{array}{r}100.0 \\
0.0\end{array}$ \\
\hline
\end{tabular}


WHC-SD-WM-SAR-064, Rev. 0

\section{CHECKLIST FOR PEER REVIEW}

Document Reviewed: RADIOLOGICAL DOSE CALCULATIONS FOR TWO POSTULATED HYDROGEN BURN CASES IN TANK 104-AN, D.A. Himes, 5/9/94

- Scope of Review: entire document

Yes No NA

[ ] [ ] $[X]$ * Previous reviews complete and cover analysis, up to scope of this review, with no gaps.

[X] [ ] [ ] Problem completely defined.

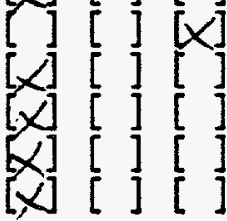

Accident scenarios developed in a clear and logical manner.

Necessary assumptions explicitly stated and supported.

Computer codes and data files documented.

Data used in calculations explicitly stated in document.

Data checked for consistency with original source information as applicable.

[X] [ ] [ ] Mathematical derivations checked including dimensional consistency of results.

[x] [ ] [ ]

[x] [ ] [ ]

$[x]\left[\begin{array}{ll}{[} \\ {[x]}\end{array}\right]$

[][]$[x]$

Models appropriate and used within range of validity or use outside range of established validity justified.

Hand calculations checked for errors. Spreadsheet results should be treated exactly the same as hand calculations.

Software input correct and consistent with document reviewed.

Software output consistent with input and with results reported in document reviewed.

Limits/criteria/guidelines applied to analysis results are appropriate and referenced. Limits/criteria/guidelines checked against

references.

$\left[\begin{array}{lll}{[]} & {[x]} \\ {[]} & {[]} & {[x]}\end{array}\right.$

Safety margins consistent with good engineering practices.

Conclusions consistent with analytical results and applicable limits.

Results and conclusions address all points required in the problem statement.

[ ] [ ] [X] Format consistent with appropriate NRC Regulatory Guide or other standards

[ ] [X] * Review ca]culations, comments, and/or notes are attached.

[x] [ ] [ ] Document approved.

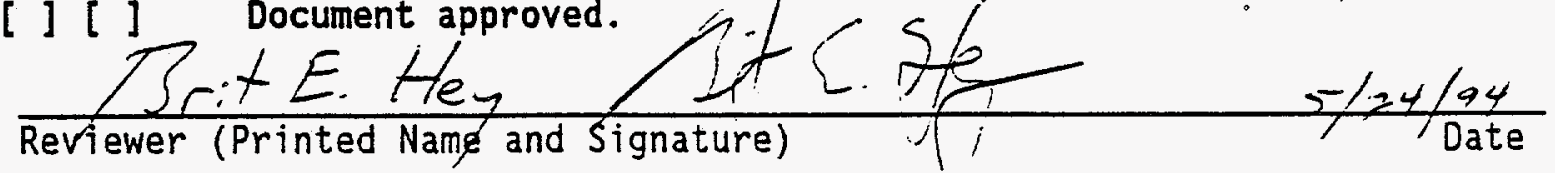

* Any calculations, comments, or notes generated as part of this review should be signed, dated and attached to this checklist. Such material should be labeled and recorded in such a manner as to be intelligible to a technically qualified third party.

DA [ ] [ ] Analysis entored into analysis database

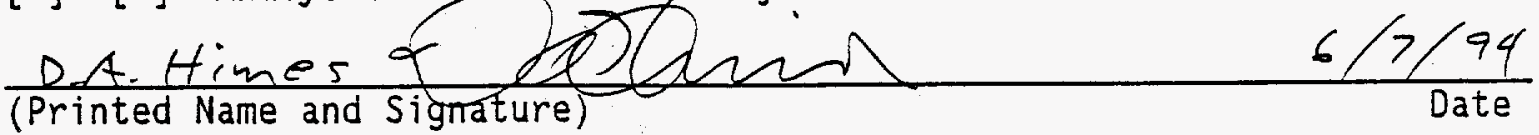


WHC-SD-WM-SAR-064, Rev. 0

\section{HEDOP REVIEW CHECKLIST \\ for \\ Radiological and Nonradiological Release Calculations}

Document reviewed (include title or description of calculation, document number, author, and date, as applicable):

RADIOLOGICAL DOSE CALCULATIONS FOR TWO POSTULATED HYDROGEN BURN CASES

IN TANK 104-AN, D.A. Himes, 5/9/94

Submitted by: D.A. Himes

Date Submitted: $5 / 24 / 9.5$

Scope of Review: entire document

YES NO* N/A

[X] [ ] [ ] 1. A detailed technical review and approval of the environmenta] transport and dose calculation portion of the analysis has been performed and documented.

[ ] [X] [ ] 2. Detailed technical review(s) and approval(s) of scenario and release determinations have been performed and documented.

[x].. [ ] [ ] 3. HEDOP-approved code(s) were used.

[X] [ ] [ ] 4. Receptor locations were selected according to HEDOP recommendations.

[X] [ ] [ ] 5. All applicable environmental pathways and code options were included and are appropriate for the calculations.

$[X] \quad[\quad[]$ 6. Hanford site data were used.

[]$\left[\begin{array}{lll}{[} & {[}\end{array}\right]$ 7. Mode] adjustments external to the computer program were justified and performed correctly.

$[x]$ [ ] [ ] 8. The analys is is consistent with HEDOP recommendations.

9. Supporting notes, calculations, comments, comment resolutions, or other information is attached. (Use the "Page 1 of $X$ " page numbering format and sign and date each added page.)

$[x] \quad[\quad]$

10. Approval is granted on behalf of the Hanford Environmental Dose Overview Pane1.

* A11 "NO" responses must be explained and use of nonstandard methods justified.

HEDop-Approved Reviewer (Printed Nama and Signature)

COMMENTS (add additional signed and dated pages if necessary):

2. No eridence of reviec and applowat ot the sce nario wav wrovided.

3 GENII CHEDCP approred) uris used for dase calculationx. GXQ (not HEDOP-approved) was usid to cakeulate $x / Q$ s fer input into GENII, lecause GENII dees roy calculate $x /$ Ls in accerdance with NRC Regulatory Huide 1.145 .24 6. Honford site-ypecific joind freqiency meterology data cias used 
WHC-SD-WM-SAR-064, Rev. 0

APPENDIX G

RELATIONSHIP OF THUNDERSTORMS TO GAS RELEASE EVENTS 
WHC-SD-WM-SAR-064, Rev. 0

This page intentionally left blank. 


\section{RELATIONSHIP OF THUNDERSTORMS TO GAS RELEASE EVENTS}

In the past at various times, the concern has been raised that thunderstorms are associated with low barometric pressure, and that in turn could promote a gas release event (GRE). If that were true, then the occurrence of lightning and a GRE would not be independent events, and the probability of a fire from this source would be identical with lightning strike probability.

Discussions with the Pacific Northwest Laboratory meteorology staff indicate that thunderstorms are not necessarily accompanied by low pressure and usually are not. In any case, to check out the possible relationship between GREs and thunderstorms, the dates when thunder was heard at the 200 Area meteorology station was tabulated for the past eight years (Table G-1). Audible thunder was counted as an indicator of the potential for cloud-to-ground lightning discharge in the vicinity of the tank farms. Typical thunderstorm duration is two to three hours.

The dates on which waste tank surface level changes started in any of the double-shell flammable gas watch list tanks are tabulated in Table G-2. These data show that 47 burps occurred during the eight year study period in al1 six double-shell tanks combined, including tank 101-SY. As shown in Table $G-1$, thunder was heard in the 200 Area on 72 days during the eight-year period. Not a single GRE occurred on the same date as a thunderstorm. Thus, it is concluded that a thunderstorm does not imply that a burp will occur and it is reasonable to treat lightning and GREs as independent events. 
WHC-SD-WM-SAR-064, Rev. 0

Table G-1. Dates of Thunder in Vicinity of 200 Area 1986 through 1993 (supplied by Dana Hoitink, PNL, May 18, 1994).

\begin{tabular}{|c|c|c|c|c|c|c|c|}
\hline 1986 & 1987 & 1988 & 1989 & 1990 & 1991 & 1992 & 1993 \\
\hline $5 / 26$ & $4 / 17$ & $4 / 28$ & $4 / 25$ & $4 / 11$ & $4 / 1$ & $3 / 14$ & $4 / 25$ \\
\hline $5 / 27$ & $4 / 28$ & $5 / 12$ & $5 / 9$ & $5 / 30$ & $4 / 7$ & $6 / 12$ & $4 / 29$ \\
\hline $6 / 3$ & $5 / 30$ & $5 / 28$ & $5 / 22$ & $6 / 6$ & $4 / 15$ & $6 / 28$ & $5 / 14$ \\
\hline $6 / 4$ & $6 / 4$ & $6 / 7$ & $5 / 23$ & $6 / 10$ & $6 / 24$ & $7 / 7$ & $6 / 11$ \\
\hline $6 / 14$ & $6 / 15$ & -- & $5 / 27$ & $6 / 22$ & $6 / 25$ & $7 / 20$ & $6 / 15$ \\
\hline $6 / 28$ & $7 / 25$ & -- & $8 / 8$ & $6 / 29$ & $6 / 28$ & $8 / 21$ & $6 / 20$ \\
\hline $8 / 29$ & $8 / 24$ & -- & $8 / 9$ & $7 / 24$ & $6 / 29$ & $8 / 22$ & $6 / 21$ \\
\hline $9 / 15$ & -- & -- & $8 / 22$ & $7 / 30$ & $7 / 12$ & -- & $6 / 28$ \\
\hline-- & -- & -- & $8 / 27$ & $8 / 20$ & $7 / 13$ & -- & $7 / 9$ \\
\hline-- & -- & -- & $8 / 30$ & $8 / 29$ & $7 / 31$ & -- & $7 / 13$ \\
\hline-- & -- & -- & -- & $9 / 18$ & $8 / 1$ & -- & $7 / 14$ \\
\hline-- & -- & -- & -- & -- & $8 / 6$ & -- & $7 / 15$ \\
\hline-- & -- & -- & -- & -- & -- & -- & $8 / 19$ \\
\hline
\end{tabular}

Table G-2. Dates of Level Changes in Double-Shell Flammable Gas Watch List Tanks (data supplied by N. E. Wilkins, May 13, 1994).

\begin{tabular}{|c|c|c|c|c|c|c|c|}
\hline 1986 & 1987 & 1988 & 1989 & 1990 & 1991 & 1992 & 1993 \\
\hline $2 / 26$ & $2 / 23$ & $1 / 3$ & $3 / 27$ & $1 / 16$ & $1 / 16$ & $1 / 17$ & $1 / 22$ \\
\hline $11 / 16$ & $5 / 4$ & $6 / 16$ & $4 / 4$ & $3 / 1$ & $1 / 22$ & $4 / 13$ & $2 / 2$ \\
\hline-- & $7 / 28$ & $9 / 6$ & $7 / 13$ & $4 / 15$ & $2 / 13$ & $4 / 20$ & $6 / 26$ \\
\hline-- & $8 / 16$ & -- & $12 / 7$ & $4 / 19$ & $5 / 16$ & $5 / 11$ & $6 / 30$ \\
\hline-- & $12 / 3$ & -- & -- & $5 / 19$ & $5 / 19$ & $5 / 15$ & -- \\
\hline-- & -- & -- & -- & $6 / 8$ & $6 / 13$ & $9 / 3$ & -- \\
\hline-- & -- & -- & -- & $8 / 5$ & $8 / 27$ & $9 / 14$ & -- \\
\hline-- & -- & -- & -- & $10 / 24$ & $10 / 15$ & $9 / 26$ & -- \\
\hline-- & -- & -- & -- & $10 / 25$ & $12 / 4$ & $10 / 21$ & -- \\
\hline-- & -- & -- & -- & -- & $12 / 5$ & $11 / 21$ & -- \\
\hline
\end{tabular}


WHC-SD-WM-SAR-064, Rev. 0

APPENDIX H

SUMMARY OF CONSERVATISMS

$\mathrm{H}-\mathrm{i}$ 
WHC-SD-WM-SAR-064, Rev. 0

This page intentionally left blank.

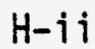


WHC-SD-WM-SAR-064, Rev. 0

\section{SUMMARY OF CONSERVATISMS}

Appendix $H$ summarizes the conservatisms used in this assessment. Table $\mathrm{H}-1$ identifies the conservatism and cross references the sections where it is used within the report. A short description of the significance of the conservatism is also provided. 

Table H-1. Summary of Conservatisms. (sheet 1 of 2)

\begin{tabular}{|c|c|c|}
\hline Identity & $\begin{array}{l}\text { Sections } \\
\text { where used }\end{array}$ & Significance \\
\hline Gas volume & $4.0,7.0$ & $\begin{array}{l}\text { Future gas releases could be larger than the past historical } \\
\text { maximums. The maximum best estimate gas release for any of these } \\
\text { tanks is } 3,287 \mathrm{ft}^{3} \text { whereas } 4,000 \mathrm{ft} 3 \text { is used for the conservative } \\
\text { evaluation. This provides a } 22 \% \text { margin. The maximum bounding case } \\
\text { combustion energy content is } 1.85 \text { times larger than the best } \\
\text { estimate (limiting tank is } 104-\mathrm{AN} \text { ). }\end{array}$ \\
\hline Gas composition & $4.0,7.0,8.0$ & $\begin{array}{l}\text { Best estimate gas composition contains } 10.95 \% \text { ammonia whereas the } \\
\text { conservative estimate contains } 20 \% \text {. This provides a } 33 \% \text { margin in } \\
\text { the heat of combustion. }\end{array}$ \\
\hline Gas release process & 4.0 & $\begin{array}{l}\text { Gas release quantities are based on maximum crust drops observed } \\
\text { between } 24 \text {-hour measurement periods. The release is assumed to } \\
\text { occur instantaneously and expels air from the tank dome space so } \\
\text { pressure remains at } 1 \text { atm. Actually, slurry gas will mix during } \\
\text { the release process and be lost via the ventilation system. }\end{array}$ \\
\hline $\begin{array}{l}\text { Lower flammability } \\
\text { limit (LFL) }\end{array}$ & 5.0 & $\begin{array}{l}\text { The assumed slurry gas mixture has a flammability limit of } 5.6 \% \\
\text { fuel gas but a LFL of } 4 \% \text { was used. If the calculated LFL were used } \\
\text { along with the maximum historical release, the dome volume which is } \\
\text { above the LFL would be limited to a few hundred cubic feet. }\end{array}$ \\
\hline Plume burning & $6.0,7.0$ & $\begin{array}{l}\text { The total gas release is assumed to accumulate and burn as a } \\
\text { partially mixed plume. In reality, the gas is mixed and diluted as } \\
\text { it enters the dome space so large volumes of flammable } \\
\text { concentrations do not occur. After ignition, the rapidly expanding } \\
\text { product gases would push out into the air space and cause further } \\
\text { dilution of the unburned gases. Burn energy is maximized by } \\
\text { assuming the } \mathrm{N}_{2} \mathrm{O} \text { burns with the most energetic fuel types first. } \\
\text { In reality, the more abundant lower energy fuel, } \mathrm{H}_{2} \text {, would burn } \\
\text { with more } \mathrm{N}_{2} \mathrm{O} \text {. }\end{array}$ \\
\hline
\end{tabular}


Table H-1. Summary of Conservatisms. (sheet 2 of 2)

\begin{tabular}{|c|c|c|}
\hline Identity & $\begin{array}{l}\text { Sections } \\
\text { where used }\end{array}$ & Significance \\
\hline $\begin{array}{l}\text { Lean concentration } \\
\text { burns }\end{array}$ & 8.0 & $\begin{array}{l}\text { Mixing studies indicate flammable gas concentrations are about } 4 \text { to } \\
6 \% \text { fuel gas. Combustion of these concentrations would be } \\
\text { incomplete and reduce the burn pressures by a factor of two or } \\
\text { three. Depending on the release characteristics, GREs in these } \\
\text { tanks may result in very little of the free volume reaching the } \\
\text { LFL. }\end{array}$ \\
\hline Crust energetics & 7.0 & $\begin{array}{l}\text { Crust energetics from tank 101-SY samples were doubled for these } \\
\text { calculations even though the lower TOC values in these tanks } \\
\text { implies the energetics should be less. This extends the envelope } \\
\text { of the bounding calculations and allows for uncertainties. }\end{array}$ \\
\hline Source term & 8.0 & $\begin{array}{l}\text { All surface crust calculated to be dried out by the plume burn was } \\
\text { assumed to be of respirable size. Dried crust is expected to } \\
\text { contain crystals with a range of particle sizes. }\end{array}$ \\
\hline $\begin{array}{l}\text { Radionuclide } \\
\text { inventory }\end{array}$ & 7.0 & $\begin{array}{l}\text { Am-241 content was increased in accordance with a sample analysis } \\
\text { suspected of overpredicting Am-241 content. The highest Cs-137 } \\
\text { inventory of any known sample from these tanks was increased non- } \\
\text { mechanistically by } 25 \% \text { to provide margin. Large margins are also } \\
\text { provided by the method for calculating isotopic releases from the } \\
\text { heated crust since maximum calculated temperatures are used for } \\
\text { saturated isotopic concentrations. }\end{array}$ \\
\hline
\end{tabular}

